\title{
Human, Technologies and Quality of Education
}

\author{
Cilvēks, tehnoloǵijas \\ un izglītības kvalitāte
}


Human, Technologies and Quality of Education = Cilvēks, tehnologijas un izglītības kvalitāte. Rịga, Latvijas Universitāte, 2018. 222 lpp.

EDITOR

Linda Daniela - University of Latvia, Latvia

\section{SCIENTIFIC COMMITEE}

Irēna Žogla - University of Latvia, Latvia

Rudite Andersone - University of Latvia, Latvia

Ilze Kangro - University of Latvia, Latvia

Iveta Kestere - University of Latvia, Latvia

Zanda Rubene - University of Latvia, Latvia

Dita Nimante - University of Latvia, Latvia

Sarmìte Tūbele - University of Latvia, Latvia

Rasa Pilkauskaité Valickiené - Mykolas Romeris University, Lithuania

Valdone Indrašiene - Mykolas Romeris University, Lithuania

Christina Marouli - American College of Greece, Greece

Beatrise Garjāne - University of Latvia, Latvia

Guna Svence - University of Latvia, Latvia

Ilze Ivanova - University of Latvia, Latvia

Zenta Anspoka - University of Latvia, Latvia

Manuel Fernandez Gonzalez - University of Latvia, Latvia

Marta Kowalczuk-Waledziak - University of Białystok, Poland

Antra Ozola - University of Latvia, Latvia

Tamāra Pīgozne - University of Latvia, Latvia

Violeta Jegelevičiené - Mykolas Romeris University, Lithuania

Elena Kocai - Vilnius Gediminas Technical University, Lithuania

Aleksandrs Kolesovs - University of Latvia, Latvia

Sandra Kalniņa - University of Latvia, Latvia

Indra Odina - University of Latvia, Latvia

Inese Jurgena - University of Latvia, Latvia

Māra Urdzinga-Deruma - University of Latvia, Latvia

Austra Avotina - University of Latvia, Latvia

Anita Auzina - University of Latvia, Latvia

(C) University of Latvia, 2018

DOI: https://doi.org/10.22364/htqe.2018

ISBN 978-9934-18-400-0 


\section{Contents}

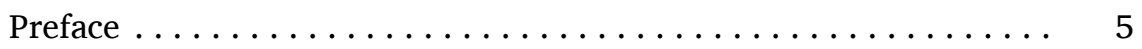

Antonina Jemeljanenko

Risk Management in the Educational Sector of Latvia . . . . . . . . . 7

Baiba Brigmane

Components of the Pedagogical Work at the University . . . . . . . . 15

Jekaterina Srebnaja, Anna Stavicka

Web-based Projects to Develop Transversal Skills

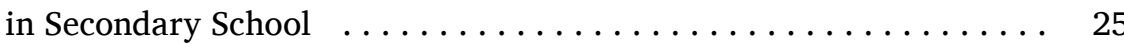

Paula Gorobeca

Professional Identity Formation Process of a Dance Teacher . . . . . 35

Anne Lise Wie

The Language Jungle: Speech Training in a Natural

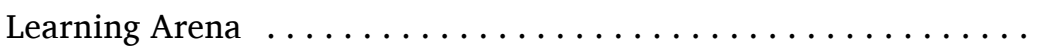

Juris Porozovs, Alvis Valdemiers

Assessing the Opinions of Pedagogical Specialities Students

on the Use of Distance Learning

Kristaps Lūkins

Assessment in Maritime Education by Students' Mutual

Collaboration .......................

Māra Urdziña-Deruma, Mārīte Kokina-Lilo,

Gunta Treimane, Lolita Šelvaha

Latvian Public Opinion on the Quality of Home Economics

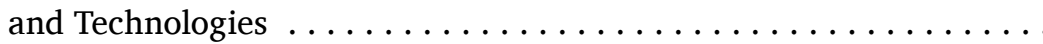

Sandra B. Sebre, Anika Miltuze, Mihails Limonovs

Maladaptive Cognitions, Hyperactivity and Inconsistent Parenting

as Risk Factors of Adolescent Problematic Internet Use . . . . . . . . 95

Yan $\mathrm{Lu}$

Curriculum Development Model for the Latvian

Language and Latvia Studies Program in China 
Anita Auzina

Teacher Educators as Participants of International Projects:

Experience, Challenges and Opportunities for the Development

of Teacher Education . . . . . . . . . . . . . . . . . . 126

Normunds Rečs

The Role of a Headmaster in the Era of Public Governance . . . . . . 136

Daiga Celmiña

Imagination as Part of Literature Study Process

in Secondary School Level . . . . . . . . . . . . . . . . . . . . . . . . 148

Jānis Skābardis, Andrejs Gluščuks, Ilvis Ābel̦kalns

Analysis and Use of Physical Characteristic Tests

in the Training Process for Football Players of Different Ages . . . . 160

Guntars Bernāts

Contribution of Orchestra Conductors to Development of

Latvian Symphony Orchestra Conducting School Since

the Beginning of the $20^{\text {th }}$ Century and Until the End of

the World War II . . . . . . . . . . . . . . . . . . . . . . . 169

Ilvis Ābeḷkalns

Specific Features of Football Class in General Education Schools . . . 182

Antra Ozola, Andris Grinfelds

The Relation of the ICT Use Patterns with Students' Reading

Literacy Achievement in IEA PIRLS and OECD PISA

Manuel Joaquín Fernández González, Tamāra Pīgozne,

Svetlana Surikova, L,ubova Vasečko

Vocational Education Institution Leaders' Virtues and

Educational Leadership Profile in Latvia: a Personality

Perspective of Education Quality . . . . . . . . . . . . . . 203 


\section{Preface}

Every year the University of Latvia (UL) organizes a conference devoted to topical research trends and the $76^{\text {th }}$ UL international scientific conference took place in 2018. The work is organized in 12 sections according to UL priority research trends and one of the conference topics is "Human, Technologies and Quality of Education" which is one of the priority research directions that unites researchers of educational science, psychology and art who perform studies on pedagogical and psychological conditions of human development. At present when the progress caused by technologies increases its rapidity sciences that study the human role in the educational process and the societal transformation processes in general face topical objectives because in 2018 countries belonging to the Bologna process decided that the focus of Higher Education should be digitalization and innovative pedagogical solutions. Educational sciences, psychology and art encounter both new challenges and the emergence of new research directions which became the discussion points for the conference participants, e.g., the traditional and innovative in different dimensions of the educational process, the place and role of technologies and digital solutions in the teaching/learning process, psychological aspects, the role of art in the individual's life and development. The present publication summarizes reports presented in the section "Human, Technologies and Quality of Education" of the $76^{\text {th }}$ UL conference and they give insight into the currently pressing research trends. All materials have been double blind reviewed before including in this volume and international scientific board was involved to ensure the international recognition of scientific ideas developed at the University of Latvia.

Researchers of the University of Latvia join the common science space of the $21^{\text {st }}$ century with their researches and scientific ideas. Due to mutual cooperation in this space they create new scientific ideas, offer their scientific thought and latest studies because despite the digitalization of different processes that allow access to the information at any time and in any place, despite the international transfer of ideas the aspects of human development are still topical both in the digital and real space therefore the education system has to offer innovative solutions how to exert impact on the learning processes because educators are the ones who learn in order to facilitate the future progress and help others learn. Educators in Higher 
Education are the ones who participate in the research of the education environment in order to offer innovative ideas and form a synergy with other sciences both performing research to develop a data-based theoretical foundation and modelling the impact of innovative ideas on different processes thus forming a basis for new theoretical and practical ideas and analyzing the outcomes of these processes.

Prof. Dr. paed. Linda Daniela 


\title{
RISK MANAGEMENT IN THE EDUCATIONAL SECTOR OF LATVIA
}

\begin{abstract}
Vulnerabilities and risks in the educational sector affect policy makers, education providers and education receivers. Weak risk management increases the likelihood of misaligned priorities, poor service delivery and financial losses. Risk management is crucial part of effective management of education, provision of qualitative educational services and sufficient fair distribution of financing for higher education. However, in Latvia this topic is only starting to gain attention of regulators and managers in the educational sector.

The task of this research is to analyse existing worldwide research on risks and risk management practices within the educational sector. Upon the results of the research basic recommendations for risk management within the educational sector in Latvia will be drawn. The purpose is to provide a short introduction to risk management in the context of management of education.

This is a desktop study research involving analysis of published articles in academic databases, books, governmental publications, regulatory texts and public online resources.
\end{abstract}

Keywords: education, educational sector, risks, risk management, quality of education.

\section{Introduction}

The Institute of Risk Management (2002, p. 2) highlights that "Risk management is a central part of any organisation's strategic management." P. Tufano (2011) states that Risk management within any organization helps to identify and consider a combination of different types of events and its impact, thus giving any organization a chance to correctly analyse opportunities and treats for strategic planning. Clark, S. B., et al. (2013) and Adams, J. F. (1973) state that ensuring safe environment, effective 
and cost efficient curriculum provision through assessing and mitigating involved risks is the core responsibility of educational institutions.

Asian Development Bank ([ADB], 2010) sets out an overview of the risks to which the education sector globally is vulnerable, which are: lack of clearly defined processes and legal frameworks (e.g. in such important processes as admissions, recruitment, budgeting, procurement), misaligned priorities, bribery and corruption, weak financial management, poor internal culture, poor Information Systems, lack of relevant expertise on management level, poor security provision. Dunklee, D. R. and Shoop, R. J. (1993), in turn, analyse and discuss risks, mentioned in [ADB] (2010), related to personnel development programmes and their compensations, environment and safety management, disputes and litigations, usage of institution's facilities and grounds by the community and risks pertained to the construction of buildings. Forlin, P. (1995) confirms that the most undervalued risks are related to the educational environment, especially health and safety of employees and students. Clark, S. B., et al. (2016) further concludes that the interconnected risks are emerging, such as cyber, data management and privacy risks, terrorism and violence risks, infrastructure and facilities' management risks; and that a broader approach to risk management is required.

As concluded by the authors mentioned above, application of risk management techniques within the educational sector is important for quality improvement, transparency in educational institutions operations and effective decision making and strategic planning.

\section{Methodology}

The study was conducted by qualitative analysis of available theoretical material, including scientific research publications, non-scientific research articles, governmental reports, academic books and news websites, with the purpose to attract interest and raise awareness of education management professionals. The materials mainly were searched in electronic academic databases (EBSCO, ERIC, DOAJ), as well as in online news portals (News.lv, bbc.com, reuters.com), institutional websites (CERT.LV, mk.gov.lv, izm. gov.lv, dvi.gov.lv, knab.gov.lv) and by use of Internet search engine for additional information. The search words used in the electronic academic database catalogues were "risk management", "risk management in education", "risku vadība izglìtībā", "crisis management in schools", "cyber security in educational sector", "legal risks in education", "lawsuits in education", "fines and sanctions to education providers". Search words used in news portals were: "corruption in education sector", "corruption 
in schools", "violence in schools", "crisis management in education", "cyber security in education", "fines and sanctions to education providers", "korupcija izglīiības sektorā", "vardarbība skolās", "krīzes vadība izglīīīā", "kīiberdrošība Izglīîibas sektorā", "sodi un sankcijas izglītības iestādēm". All abovementioned search word combinations were used in Internet search engine for additional information.

All found articles and publications were analysed for definition of risk management by different authors, the risk management approaches, risk theories, examples and practical application of risk management techniques in the educational sector across the world.

\section{Results}

Risk management serves as the base for effective planning and strategic development for many organisations. However, it is often ignored in the educational sector. Following searches in EBSCO, ERIC and DOAJ databases, publications performed by Latvian researches about risks and risk management in education were not found at all. Within the Latvian University database of dissertations it was possible to find only one work titled as "Impact of Information Risk Management on Strategic Decision Making within the Business Management Context" by Schwerd, S. published in 2017. Following the search in library catalogues (Latvian University Library, Central Riga Library), it was not possible to find specific texts related to risk management within the management of education, instead some books found were related to the risk management in business and at the workplace. On the other hand, performing the same search for works written by foreign authors, it was possible to find a high number of books, publications and research projects conducted in the United States, Australia, Asian countries, United Kingdom, the Republic of Ireland, Sweden, Norway and Finland. Thus, it is possible to conclude, that there has not been performed any extensive research on this topic in Latvia, despite the worldwide accepted importance of risk management for any organisation in any sector.

Summing up the desktop research results, the author selected and analysed several risks, which were most often analysed in the researched materials and, therefore, may have the highest level of relevance to the educational sector: privacy and cyber security risks, risk of corruption, legal risks (compliance, litigation, lack of internal processes) and external risks (Tufano, P., 2011; Clark, S. B., et al., 2013; Adams, J. F., 1973; [ADB], 2010; Dunklee, D. R. and Shoop, R. J.,1993, Forlin, P., 1995; Abraham, J. M., Baird, R., Neugebauer, F., 2013). 


\section{Discussion}

\section{Cyber Security Risk in the Educational Sector}

According to the statistics provided by CERT.LV, solely during 2017 only in Latvia in total, were registered 477252 endangered by cyber attacks unique IP addresses.

According to Cyber Security Strategy of Latvia (2014) and Clark, S. B., et al. (2016), Cyber security risks are dangerous for educational sector from various angles:

1. Confidential data stored in educational institutions' and educational authorities' digital spaces may be at risk of being stolen, damaged or destroyed;

2. Digital devices used by educational institutions and authorities may be damaged by a virus and destroyed indefinitely causing severe financial damage.

According to the Cyber Security Strategy of Latvia (2014), there is lack of academic study programs and scientific activities in the field of cyber security in Latvia, and in the respective fields students studying abroad are not motivated to return to Latvia due to remuneration issues and lack of opportunities for professional development. Furthermore, according to latest statistics published the Ministry of Education (2018), in 2017 there was one programme dedicated to cyber security - Master in Cyber Security Management, provided by BA School of Business and Finance. Moreover, according to a study by the World Economic Forum, Latvia ranks only $110^{\text {th }}$ in terms of availability of scientists and engineers inside the country.

According to Cyber Security Strategy of Latvia (2014) in order to tackle cyber security risks, it is important to carry out educational and information campaigns for the promotion of public awareness for cybersecurity, cybercrime and existing threats. The author adds that it is crucial to encourage development and implementation of relevant specialisation programmes in higher education, include cyber security topics in the curriculum of secondary education and encourage practical application of cyber risk management techniques in the management of education (Clark, S. B., et al., 2013; Abraham, J. M., Baird, R., Neugebauer, F., 2013).

\section{Corruption Risk}

Risk of corruption mainly is driven by unethical behaviour of responsible employees and school administrators, which in turn could be limited by lack of well-defined procedures and regulations governing purchasing of supplies, use of common textbooks, hiring service providers etc. Corruption 
risk affects the quality of education, as well as safety and wellbeing of students and teachers. Bribes result in weakening of the quality of education, non-implementation of relevant procedures, assessment criteria and certification results (Chr. Michelsen Institute, 2006; Hallack and Poisson, 2007).

Upon analysing available research publications ([ADB, 2010; Chr. Michelsen Institute, 2006; Hallack and Poisson, 2007) and related news articles published in the Corruption Prevention and Combating Bureau of Latvia (KNAB.gov.lv), the State Police of Latvia website (vp.gov.lv) and local news websites (News.lv, tvnet.lv, delfi.lv), the following issues related to corruption risk were identified by the author:

- Absence or non-implementation of established processes and methods for reviewing teacher performance and teacher external engagements provides opportunities for corruption risk;

- Corruption may be the reason for reduced quantity of textbooks and low textbook quality;

- Deficient and unsafe materials may be used in school construction as a result of corruption;

- Corruption incidents may result in differing funding levels provided to similar educational institutions. Moreover, corruption incidents have resulted in more paperwork involved for schools applying for funding, in order to increase the controls over the corruption risk.

\section{Legal risks}

Educational sector often is subject to regulatory reforms and regulatory changes. In Latvia, education sector is not only the subject to local laws, but also to several common European Union (EU) laws. Education is strictly regulated and requires authorities and school administrators to closely follow changes legal requirements and stay compliant. Ensuring strong compliance would additionally foster better quality in provision of education (Abraham, J. M., Baird, R., Neugebauer, F., 2013; ADB, 2010; Chr. Michelsen Institute, 2006; Clark, S. B., et al., 2013; Hallack and Poisson, 2007).

One of such upcoming regulations, which will impact all educational institutions, is the EU General Data Protection Regulation (GDPR). This regulation requires each institution, especially public, which processes large amounts of personal data, to appoint Data Protection Officer. Moreover, apparently the impact on academic research will take place, as the data availability will become more complicated. The real outcomes and effect on educational sector of this regulation will become obvious only after the regulation will come in force. 
Finally, the educational reforms that happen regularly in Latvia may not always be in interests of all stakeholders, what creates further risks requiring additional research.

\section{External risks}

External risks may take form of flood, fire, terrorist attacks, nature disasters, failures in supply management, losing a key employee, sudden death of child or teacher, etc. Disruptions caused by external factors, occurrence of which is not possible to control, can happen at any moment. It is important to be prepared and ready to face the incident, with clearly planned actions and appointed beforehand responsible persons, to enable organizations to continue functioning with as little interruption as possible (PKF UK LLP, 2011; ADB, 2010; Lehtonen, J., Silina, R., Abelniece, B., 2011).

In Latvia, the Ministry of Education and Science has developed the Civil Protection Procedure (2011), the Children Rights Protection Inspection has published the Crisis Management Procedure for Schools (2015), but the Employer Confederation of Latvia published the Best Practice Management Handbook (2010). Further research is required, in order to assess, whether and to what extent these documents are utilised, which is not in scope of this publication.

\section{Conclusions}

Due to lack of sufficient information from authors and information sources of Latvia, it was challenging to analyse risk management and current risks in educational sector in Latvia. Therefore, author will continue to research this topic by applying other methods, such as interviews, empirical research, applied quantitative approach. To conclude on current research results, academic studies on risk management in educational sector of Latvia should be encouraged. Curriculum programs in higher education institutions related to risk management problems should be developed and regularly organised scientific conferences dedicated to risk management, where future risks and required expertise would be assessed. Existing worldwide research should be considered for addressing specific problems in Latvia and the up-to-date statistics should be available for researches.

Corruption risk related to school funding can be mitigated by a clear centralised sourcing and procurement policy for all educational institutions with embedded control techniques for and specific criteria set for choice of suppliers.

One of the steps to tackle cyber risks is to follow and develop the Cyber Security Strategy and to ensure that education in ICT cyber security is 
integrated it into the school curriculum. Systematic continuing education sessions should be organised for teachers on tackling security, privacy and cyber security issues, as well as trainings on actions that need to be taken in the events of unexpected disaster situations caused by the external factors.

\section{References}

Abraham, J. M., Baird, R., Neugebauer, F. (2013). Leveraging Enterprise Risk Management: Opportunity for Greater Relevance. EDUCAUSE Review, Nov.-Dec. 2013, 48(6), 28-40. ISSN-1527-6619. ERIC database.

Adams, J. F. (1973). The Governing Board's Role in Risk Management and Insurance for Higher Education. Journal NACUBO Professional File, Mar. 1973, 4(1). ERIC database.

Asian Development Bank (2010). Education sector risk assessment. Philippines: ADB. ISBN 978-92-9092-163-9. Retrieved from https://www.adb.org/sites/default/files/ institutional-document/31318/guidance-note-education-sector-risk-assessment.pdf.

Basel Committee of Banking Supervision (2011). Principles for the Sound Management of Operational Risk. Bank for International Settlements, June 2011. Retrieved from https://www.bis.org/publ/bcbs195.pdf.

CERT.LV (2018). Publiskais pārskats par CERT.LV uzdevumu izpildi 2017. gadā (Public report on fulfillment of CERT.LV tasks). Published on 23.03.2018 online on CERT.lv. Retrieved from https://cert.lv/uploads/CERT-LV_gada_2017_publ_galaversija.pdf.

Chassang, G. (2017). The impact of the EU general data protection regulation on scientific research. Ecancermedicalscience online journal, 11, 709. Retrieved from https:// www.ncbi.nlm.nih.gov/pmc/articles/PMC5243137/.

Chr. Michelsen Institute (2006). Corruption in the Education Sector, U4 Anti-Corruption Resource Center, Issue 4. Bergen, Norway: Chr. Michelsen Institute. Retrieved from https://www.cmi.no/publications/file/2563-corruption-in-the-education-sector.pdf,

Clark, S. B., DeCato, K. D., George, D., Henderson, D., Henry, A. A. Jr., Hoch, Ch. (2016). Enterprise Risk Management in the Great City Schools, Spring 2016. Washington D.C.: Council of the Great City Schools. ERIC database.

Dunklee, D. R., Shoop, R. J. (1993). A Primer for School Risk Management: Creating and Maintaining District and Site-Based Liability Prevention Programs. U.S.A.: Allyn and Bacon.

Forlin, P. (1995). Risk management in Australian science education: A model for practice. Australian Science Teachers Journal, June 1995, 41(2), 22-28. ISSN-0045-0855.

Hallak, J., Poisson, M. (2007). Corrupt Schools, Corrupt Universities: What Can be Done? UNESCO: Ethics and Corruption in Education. Paris: International Institute for Educational Planning. Retrieved from www.unesco.org/iiep.

HM Treasury (2004). The Orange Book: Management of Risk - Principles and Concepts. London: HMSO. Retrieved from www.hm-treasury.gov.uk/d/orange_book.pdf.

Institute of Risk Management (2002). The Risk Management Standard. London: IRM. Retrieved from https://www.theirm.org/media/886059/ARMS_2002_IRM.pdf.

Lehtonen, J., Silina, R., Abelniece, B. (2011). Riska un Krizes komunikācija (Risk and Crisis Communication). Latvia: Biznesa Augstskola Turība.

Martoglu, M. (2015). The Role of School Management in the Prevention of School Violence. Procedia - Social and Behavioral Sciences, 182 (2015), 695-702. Elsevier Ltd. Retrieved from https://doi.org/10.1016/j.sbspro.2015.04.815. 
Ministry of Defence of Latvia (2014). Latvijas kiberdrošǐbas stratēgija 2014-2018 (Cyber Security Strategy of Latvia 2014-2018). Retrieved from https://www.unodc.org/res/ cld/lessons-learned/lva/latvijas_kiberdrobas_stratija_html/Kiberdrosibas_strategija.pdf.

Ministry of Education and Science of Latvia (2018). Pārskats par Latvijas augstāko izglītibu 2017. gadā. Galvenie statistikas dati (Overview of Latvian Higher Education in 2017. Key Statistics). Retrieved from http://www.izm.gov.lv/images/izglitiba_augst/Parskats-parLatvijas-augstako-izglitibu-2017gada.pdf (2018-04-27).

Ministry of Education and Science of Latvia (2018). Studiju programmas 2017 (Study Programmes 2017). Retrieved from http://www.izm.gov.lv/images/statistika/augst_ izgl/Studiju_programmas_2017.xlsx (2018-04-27).

Murphy, K. L., Donovan, J. B., Berg, D. A. (2016). Analysis of Risk Management in Adapted Physical Education Textbooks. Physical Educator, Spring 2016, 73(2), 388-414. ISSN-0031-8981. Retrieved from http://dx.doi.org/10.18666/TPE-2017-V74-I1-6441.

Patrinos, H. A., Kagia, R. (2007). In The Many Faces of Corruption: Tracking Vulnerabilities at the Sector Level. Washington, DC: The World Bank. Retrieved from http:// documents.worldbank.org/curated/en/571831468315566390/The-many-faces-ofcorruption-tracking-vulnerabilities-at-the-sector-level

PKF UK LLP (2011). A Good Practice Guide To Risk Management Within The Further Education Sector. London: PKF (UK) LLP. Retrieved from https://www.aoc.co.uk/sites/ default/files/CFDG_Risk_Management_Guide_0.pdf. 


\author{
Baiba Brigmane \\ BA School of Business and Finance, Latvia
}

\title{
COMPONENTS OF THE PEDAGOGICAL WORK AT THE UNIVERSITY
}

\begin{abstract}
Competitiveness of economy and well-being of the population are increasingly dependent on an educated society, where universities and their academic staff play an important role in the learning process of students and adults - participants of courses. Therefore, the author of the article aims to find out what are the most important components of the pedagogical work, which must be emphasized in the activities carried out by the teaching staff in order to achieve ever better learning outcomes. Data of two studies carried out by the author are being analysed - evaluation provided by future entrepreneurs of their involvement in the study process during the courses and students' opinion about competences necessary for the lecturer. The author has concluded that cooperation between students and lecturers in the practical application of theoretical knowledge, its evaluation and improvement of mutual communication skills, are essential for the study process. The importance of developing competences for lifelong learning of the future society, as well as opportunities for developing competences that are to be improved in cooperation with students, who would have acquired secondary education based on new content, should be emphasized among the lecturers.
\end{abstract}

Keywords: communication, competence, cooperation, lecturer, pedagogical work.

\section{Introduction}

Future competitiveness of Latvia in the global economy depends on human resources, which in the course of a knowledge-based society development are able to adapt to a dynamically changing environment and respond to changes in the global economy. Along with a rapid development of technologies and the global economy, progressive societies turn into the societies in which knowledge and information are the main means of production. When looking from a long-term view, knowledge is more 
important for the economic competitiveness rather than the equipment, at the same time and the ability to acquire new competences that are needed throughout the life are more significant than a certain qualification. Future society is based on educated knowledge providers - the academic staff of universities - and educated consumers. Therefore, knowledge based society and economy requires large-scale and socially inclusive investments in human capital, especially in knowledge, education and research. The surrounding world demands changes also in education content, as well as in the attitude of the process participants. "Educational success is no longer primarily a reproduction of the content of knowledge, but the practical use of knowledge, applied in new situations". (Fadel, et al., 2017) A new general education competence approach in the content of the studies, developed in Latvia, is oriented towards the use of knowledge. Moreover, higher education establishments should start preparing for a new approach towards the content acquisition, promoting innovation in teaching methods and the use of new technologies. "In the $21^{\text {st }}$ century the new generation can be directly defined as the digital generation. Digital technology that provides opportunities is a part of their integral existence component. Taking into account digital generation's needs, also pedagogy needs to respond to these needs". (Baldinšs, 2017) In few years, lecturers will work with students who have acquired secondary education oriented towards the use of knowledge. Therefore, the author of the article has set an aim to find out the characteristic components of the pedagogical work that should be emphasized in the work of academic staff in their relationship with students. When analysing scientific literature and conducting students' opinion research, the following main components of pedagogical activity can be put forward: communication, self-examination, creativity, as well as organizational and methodological approach. A balanced use of these components ensures a competent and active collaboration between the knowledge user and the knowledge carrier. Based on the research data from the doctoral dissertation, competence is a skill, based on attitudes and knowledge, and used as an ability to perform and build self-experience in accordance with personal development.

In order to raise an importance of the pedagogical competence of the academic staff in higher education and to improve results of the pedagogical interaction during the study process, activities characterizing the pedagogical competence of lecturers and attesting the conformity of higher education reforms with professionalism, and a way how it would be possible to improve the quality of higher education by focusing on science and research based studies, should be identified. The world-renowned studies acknowledge that the key skills of the $21^{\text {st }}$ century are as follows: 
Collaboration, Communication, Creativity and Critical Thinking (Trilling, Fadel, 2009).

Communication is becoming a leading competence in most professions. According to the study carried out at the Harvard University in 2015 in which 25 million job advertisements were analysed, communication ranks the first in 13 occupational groups, it also ranks the second in 2 occupational groups out of 28 skills defined in 15 occupational groups (Burning-glass study, 2015). These skills are especially important for lecturers, because they should be able not only to apply this skill themselves but also to help students master and improve these skills. The concept of creativity raised in Latvia implies assessing the necessary skills and abilities of young people, emphasizing the educational system's reorientation towards developing abilities of young people to think independently, critically and creatively, as well as to cooperate and adapt.

\section{Methods and Materials}

The methodological basis of the research is grounded on theories of philosophers, psychologists and educators about human-pedagogical processes in the learning nowadays, a structurally procedural approach to educational work foreseeing a united implementation of objective and subjective work components in the learning and providing the purport of the learning (Леонтьев, 2007; Giese, 2010; Göhlich, 2007; Bruner, 1971; Кларин, 1998; Špona, 2006). The main principle of humanism is satisfying human needs and enhancing development of abilities within the learning, while the task of the practice is to actualize the components of pedagogical work necessary for lecturers, which would ensure an acquisition of reasonable research results that can be used for improvement of the study process. The article is based on the notion that "the science of pedagogy is not a fundamental science, but the theory and practice of organized learning acquisition process. Its educational, developmental and educative goals in their unity are oriented towards the preparation of children / pupils / students for life and activities in the cultural environment". (Žogla, 2018)

The research data from the doctoral dissertation, defended by the author, about the learning process of future entrepreneurs, where the opinion of 209 respondents was recorded before and after the studies, has been analysed in the article (Brigmane, 2014). Out of all the students who participated in the State Support Program for Young Entrepreneurs the "Starter Program", these people volunteered to analyse their self-experience in the learning process. Respondents included: 112 (54\%) women and $97(46 \%)$ men covering all regions of Latvia, 3\% with a primary education, 
$60(29 \%)$ - with secondary education, with a bachelor's degree 79 (38\%) and a master's degree $-62(30 \%)$, age till 25 were $27(13 \%)$, age between 26 and $45-135(65 \%)$, over 45 years $-47(22 \%)$ of course students. The survey was conducted both before and after the completion of studies in accordance with the author's developed self-assessment criteria.

The methods of mathematical statistics were used to test the reliability of the research results. Since in this specific case, the same audience ( $n=209$ ) was repeatedly tested, the Wilcoxon Signed Ranks Test and the Spearmen's Correlation Coefficient matrix were used to process the data obtained in the survey. Apart from that the results of a study carried out by the author in 2017 among 167 students studying at the BA School of Business and Finance were taken into account to identify the competences necessary for lecturers.

In the research participated $70(42 \%)$ men and 97 (58\%) women, age between 20 and 23, everyone with a secondary education. Firstly, students responded to the questions about the importance of pedagogical competencies and secondly, answered the open questions about the competencies necessary for the lecturer. Students ranked the proposed 5 pedagogical components by significance from 1 to 5 . When calculating and assuming the highest rated component has an index 1, the remaining values obtained the corresponding indexes (see Figure 1).

Although discussions criticising students' competence to assess the professionalism of lecturers can be found in the literature, students' learning experience, their expectations during the study process and their view regarding lecturer's didactical performance are useful resources for studying professional activities of lecturers and identifying better practice in the quality culture of higher education institutions (Eisenberger, et al., 2005; Schmidt, 2008).

Documents regulating activities of the universities in Latvia and Europe - European guidelines for ensuring the quality of higher education in the area of the European higher education (Standard and ..., 2015) and the Law on Higher Education (Law on..., 1996) were used in the study.

\section{Results}

Lecturers within their professional activities form daily interaction by communicating with different target groups: students, colleagues and representatives of relevant professional organizations (employers). Communication with students is a mutual intergenerational cooperation that points out the ability to collaborate, to accept different opinions, to speak with respect, to reach an agreement, to listen to, to encourage and to evaluate. Studying views of the students who study at the BA School 
of Business and Finance results indicate that communication skills are set forward as the main and priority competences (with an index 1) (see Figure 1). The most typical responses to the open question about the communication skills necessary for a lecturer are as follows: “... to adapt to different audiences; ... to collaborate with students, to listen to and support or correct a student's point of view; ... understanding a student's level of competence while reading lectures; ... to be a life experienced person sharing the former..." Skills to be advanced the most in communication with colleagues are related to creating more targeted and closer cooperation among lecturers of different universities in the interdisciplinary context of sciences and strengthening science and research-based study provision. "In communication with representatives of professional organizations (employers), knowledge should be up-dated on a regular basis. In addition to the above, the students surveyed within the study have pointed out that “... a lecturer shall have an up-to-date knowledge about the topicalities and innovations of the course; ... not only theoretical knowledge, but also a huge practice obtained working in the relevant field; ... understanding not only their own specialty, but also the related ones." Currently communication has become one of the most dynamic social phenomena, but cooperation during the study process becomes an essential principle throughout the whole education process. Therefore, a lecturer's task is to organize the academic work in such a way that students would feel as equal partners participants of the process, where intergenerational communication results in an exchange of self-experience.

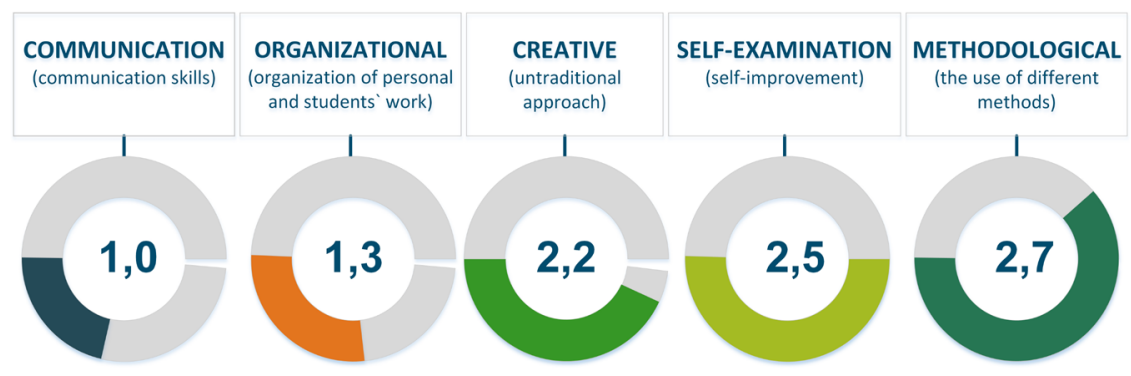

Figure 1. Components of Pedagogical Work

The study reveals that the organization of lectures has been evaluated as the second (index 1.3) most important component of the pedagogical work (see Figure 1). In order to create a free and creative cooperation with the audience during the lectures, a lecturer guides students towards acquiring target oriented cooperation skills that allows doubts, mistakes, support in common searches and promotes the feeling of togetherness in 
communication. The target oriented cooperation is grounded in democratic style of performance and such means and methods of human pedagogy applied by lecturers that ensure self-realization of the audience. The cooperation manifests in an independent choice of what, how and how much a student learns in acquiring personally significant items. In the work with adults, lecturers structure the course according to the stages of the organization of cooperation: psychological preparation, which includes setting the purpose; practical preparation, which includes coordination of the learning resources for acquiring the content and achieving a goal; implementation of the activity, which includes content acquisition and assessment of the work process and its results, as well as self-assessment. When studying the organization of the learning process of future entrepreneurs and formation of their self-experience, it turned out that only half of the audience felt like having a dialogue with an opportunity to express their opinion, but 63 percent of respondents stressed that they felt confident of having a possibility to ask a question to the lecturer (see Figure 2).

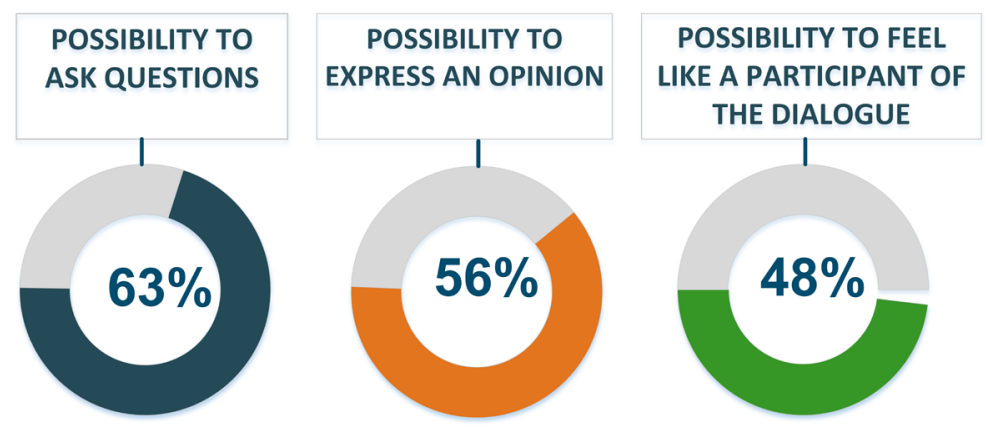

Figure 2. Cooperation with Future Entrepreneurs during the Studies

Another component is creativity that is ranked as the third (index 2.2) most significant element (see Figure 1). Creativity in education focuses on interdisciplinary cooperation and development of skills; imagination that is developing an individuality; creative thinking and talent-improving process of the learning. In creative thinking, both the lecturer and also the student shall adopt a new view of things, situations and processes, as well as various new ideas and their solutions, formation of which is not a result of template thinking. The main components of such learning are experience and dialogue. Paulo Freire has evaluated this complicated pedagogical activity and he claims that the normal role of people in the world is not a passive one. They are participants of the creative dimension, what results in the ability to adapt to the reality, make choices and transform the reality (Freire, 1985). 
By implementing study plans, programs and didactical methods, which in turn activates self-directed and independent study and research skills, a purposeful transition from lecturer-led studies to a student-centred selfeducation process is achieved. In the above mentioned process, a lecturer and his pedagogical competence is an important component of the structure.

The study shows that self-examination is rated as the fourth competence (index 2.5) in the pedagogical work (see Figure 1). The lecturer shall continuously follow his/ her growth by assessing the relevance of the use of self-experience and competence to the situation. The inclusion of new experiences in the content of the previous experience requires a cognitive process - learning. Therefore, in the pedagogical work, both the students and the adults have certain cooperation difficulties in the organization of process of acquiring new competences and self-experience. Previous experience of each and every person, as an inherent value of the learning process, resists new experience, because it is difficult to give up the old and the habitual that possesses a personal value. The experience-oriented theory by Michael Göhlich views interaction between the activity and the passivity. Difference between the activity and the passivity is hidden in "relevant prioritization" (Göhlich, 2007, 191).

The methodological component (index 2.7) is essential in the pedagogical process, as one of the most difficult issues in organizing the contemporary educational process is the question of how to achieve a situation that every participant of the educational process is aware of his/ her learning goals (see Figure 1). Through the method of cooperation, goals of a pedagogue and each participant of the process approximates: a pedagogue clearly understands what and how should be learnt and which methods should be used, and offers options, but participants of the process choose and coordinate the content of the learning process and the organization of its acquisition.

The study on identifying the learning needs of future entrepreneurs showed that before the studies, majority of students - 45 per cent, considered the group work method as the most effective, but 39 per cent found the practice application as such. After the studies, 68 per cent of the audience recognized the practice application as the most productive method, 23 per cent gave priority to the group work method, and 9 per cent - to the monologue method. David Kolb considers that the learning process of a person is based on the experience and skills to gain a new experience, to reflect it, to conceptualize and to experiment (Kolb, 1974). Human-oriented science of pedagogy focuses towards a human being as the highest value; the advancement processes of his/ her natural and social development; possibilities and preconditions for his/ her free self-development. 


\section{Discussion and conclusions}

The above mentioned can only be implemented by the academic staff that is professionally trained and academically educated according to modern competences. However, also the higher education institutions should actively participate in the improvement of professional qualification of lecturers and implementation of requirements of regulations. Article 5, p. $2^{1}$ of the Law on Higher Education stipulates the tasks of the universities: The universities... establishes an internal order and mechanisms to provide qualification level of the academic personnel and its work quality; Article 26, p. 5 - the personnel of the university, its rights and duties: the leadership of the university shall take care of the personnel's work conditions and provide a possibility to raise qualification and retrain. (Law on ..., 1996). In p. 1.5, the European guidelines for quality assurance in the area of the European higher education state that institutions of higher education shall provide competence of their own teaching staff. The recruitment of lecturers shall be organized fairly and openly (Standarts and ..., 2015). As Ausma Špona indicates, every human being is unique and unrepeatable both in terms of a genetic nature and the way of life (Špona, 2006).

Studying the components of the professional pedagogic work of the university's teaching staff allows to conclude:

- Motivation of the personality, meaningful learning, self-analysis and self-assessment are the concepts of human pedagogy expressing respect towards human autonomy in the teaching process that is a precondition for cooperation between lecturers and students.

- In academic studies, the procedural actions shall be actualized: problem solving; reflexive, critical and creative thinking; searching for the personal significance; the use of a newly acquired experience. These findings were particularly applied to the study on the selection of adult learning content and forms, and organization of its process.

- Creative learning that features the transition from lecturer-led studies to a student-centred self-education process, activating selfdirected and independent learning and research skills during life, becomes more and more topical. As a result, learning process that nourishes talents and aims towards an interdisciplinary cooperation and development of skills, as well as an individuality-developing imagination and creative thinking, is being formed.

- Lecturers shall form a structure of the lecture according to the stages of organization of the cooperation: psychological preparation, which includes setting goals; practical preparation, which includes the coordination of learning resources for the acquisition of content 
and the achievement of the goal; implementation of the activity, which includes content acquisition, improvement of self-experience, assessment of the work process and its results; and self-assessment.

- Analysing the scientific literature and conducting the study of students' opinions, communicative, organizational, self-examination, methodological and creative components should be considered as the main in the pedagogical work. Advancement of communication skills is especially important for the lecturers, as they have to be able not only to use the former, but also help students to master and improve them.

\section{References}

Augstskolu likums (Law on Higher Education) (1996). Latvijas Vēstnesis, 179(462), 17.11.1995.; Ziñotājs, 1, 11.01.1996.

Baldiņš, A. (2017). E-Pedagoǵijas satura pilnveide. Humanitārās un sociālās zinātnes (Improvement of E-Pedagogical. Content. Humanities and Social Sciences), 27, 41.-50. lpp.

Brigmane, B. (2014). Pieaugušo pašpieredzes veidošanās mācǐšanās procesāa (Formation of adults self-experience through the process of learning). Riga: RPIVA.

Bruner, J. S. (1971). Process of education reconsidered. Phi Delta Kappan, 53, 18-21.

Burning - glass study (2015). The Human Factor: The Hard Time Employers Have. Finding Soft Skills, Burning Glass Technologies. Retrieved from http://burning-glass.com/ wp-content/uploads/Human_Factor_Baseline_Skills_FINAL.pdf.

Clarin, M. (1998). Innovacii v mirovoj pedagogike (Innovations in world pedagogy). Moscow-Riga. Pedagogical center "Experiment".

Eisenberger, K.; \& Kramer, J. W. (2005). Möglichkeiten und Grenzen der Lehrevalution an einer Hochschule. In: Kramer, J. W. (Hrsg.) Hochschulen im Spannungsfeld zwischen Lehre und Forschung (S. 39-74). München und Mering: Rainer Kampp Verlag.

Fadels, Č., Bialika, M., Trilings, B. (2017). Četru dimensiju izglitỉba. Skolēnu panākumiem nepieciešamās kompetences (Four-Dimensional Education: The Competencies Learners Need to Succeed). Lielvārde: izglìtības uzñēmums "Lielvārds".

Freire, P. (1985). The politics of education: Culture, power and liberation. South Hadley: Mass Bergin \& Garvey, 209 p.

Giese, M. (2010). Der Erfahrungsbegriff in der Didaktik - eine semiotische Analyse. Zeitschrift für Pädagogik, D 7484, Jan./Feb. 2010.

Göhlich, M. (2007). Aus Erfahrung lerner. In: M. Göhlich, C. Wulf, J. Zirfas (Ed.), Pädagogische Theorien des Lernens (S. 191-202). Weinheim und Basel: Beltz.

Kolb, D. A., Rubin, I. M., McIntyre, J. M. (1974). Organizational psychology: an experiential approach (2nd ed.). Englewood Cliffs, NJ: Prentice-Hall.

Leontjev, D. A. (2007). Psihologija smysla (Psychology of meaning). Moscow: Smisl.

Schmidt, B. (2008). Qualität der Lehre an Hochschulen. Zeitschrift für Pädagogik. Weinheim und Basel: Beltz Verlag. 
Špona, A. (2006). Audzināšanas process teorijā un praksēe (The process of upbringing in theory and practice). Rīga: RaKa.

Standards and Guidelines for Quality Assurance in the European Higher Education Area (ESG 2015). Retrieved from http://www.enqa.eu/wp-content/uploads/2015/11/ESG_ 2015.pdf.

Trilling, B. and Fadel, C. (2009) 21st Century Skills. San Francisco, CA: Jossey-Bass.

Žogla, I. (2018.) Science of Pedagogy and Educational Sciences. Latvijas Universitātes

Raksti, 816, 87-109. Retrieved from https://doi.org/10.22364/ped.luraksti.816.07. 


\title{
WEB-BASED PROJECTS TO DEVELOP TRANSVERSAL SKILLS IN SECONDARY SCHOOL
}

\begin{abstract}
It is apparent that the system of education is one of the key actors in shaping knowledge, skills and attitudes necessary for students to live and work in the $21^{\text {st }}$ century. The world is rapidly changing, therefore, these changes have to be considered within all the education cycles. However, the education system in Latvia does not always succeed in equipping students with the knowledge they can transfer and use in real-life context to meet the requirements of the $21^{\text {st }}$ century. The modern realities substantiate the necessity for young people to possess transversal competences and soft skills being able to adjust to the rapidly changing world facing and resolving challenges in diverse contexts. The new generation of learners strives to be actively involved in the learning process and acquire skills which link traditional knowledge with research and inquiry-based active learning through collaboration and networking. Therefore, inquiry based web-based projects can become the instrument for paradigm change to reinforce the shift towards more relevant competency-based education programmes.

The study analyses the ways and forms for integrating web-based projects in foreign language teaching within the $21^{\text {st }}$ century perspective. WebQuests developed within the research framework prove to be an effective tool to address the necessity to connect the learning process to real life. The article provides selected results of the study exploring the application of learning technologies within the teaching and learning process.

The research is conducted in the framework of the project "Multilingual and Multicultural University: Preparation Platform for Prospective International Students" (No. 1.1.1.2/ VIAA/1/16/019) co-funded by ERDF.
\end{abstract}

Keywords: Educational Technology, Paradigm Change, 21 $1^{\text {st }}$ Century Skills, Transversal Skills, Inquiry-based Learning, Active Learning, Collaboration and Networking, English Language Teaching, Learning Technologies, Web-based Projects, WebQuests. 


\section{Introduction}

ICT application in educational setting has long become the area of major interest for scholars worldwide. The research explores how the application of ICT in the English language teaching improves academic performance of secondary school students. Today, the world is rapidly changing, which calls for a new study, since the skills, competencies and attitudes required to participate in all spheres of life have changed as well (European Report on Quality Indicators of Lifelong Learning, 2002; School 2030 Project). The main trends in the development of modern society connected with processes of globalization and digitalization find direct reflection in the educational process. Nowadays, student exposure to ICT tools imposes new challenges and demands in secondary education. Traditional education methods do not support modern technology-driven, dynamic world (ATS2020). In order to keep up with time, education has to evolve providing the learner with the more meaningful learning environment. The education system is currently expected to prepare students for these changes, to equip the students with new competences required for the $21^{\text {st }}$ century demands.

The education system in Latvia is going to implement a new competence-based approach to develop students' competences that would prepare students for real life and enable them to function effectively in the $21^{\text {st }}$ century (School 2030 Project), which adds to the topicality of the issue as well.

In the meantime, present-day school-leavers fail to develop the competences they need to succeed in life. Graduates' inability to apply the skills acquired at future workplaces sparked the need to bridge the 'education-to-employment' gap. In view of that, schooling for both employability and life can address this disparity. The focus must therefore be put on the skills necessary for the world of work and success in life, the skills that students would be able to transfer to new environments (Barton, Farrell, Mourshed, 2013). These transferable or transversal skills are critically important to success in school, further education and the world of work. They include the ability to think critically, take initiative, use digital tools, solve problems and work collaboratively (School 2030).

The article introduces the selected results of the study which aimed to find out whether the involvement in web-based inquiry-oriented projects enhance secondary school students' transversal skills.

\section{Theoretical Background}

The education system in Latvia is currently undergoing the much needed transformation and is expected to equip contemporary students 
with new competences necessary to meet the demands of the $21^{\text {st }}$ century. In light of this educational reform, considerable attention has been given to the concept "key competences" (sum of skills - basic and new basic skills, needed to live in contemporary knowledge society) these days (Terminology of European Education and Training Policy, 2014). These competences are context-independent and built by students; they can be applied for succeeding in different situations according to varying demands and are valuable for today's world (Weinhert, 1999). The development of key competences to promote learning outcomes (what a learner will know or be able to do as a result of a learning activity (Adam, 2004)) is brought to the fore of the educational change. However, learning outcomes incorporate not barely the competences, but also the knowledge (the outcome of the assimilation of information through learning), and skills (the ability to apply knowledge to complete tasks and solve problems) (The Recommendation of the European Parliament and of the Council on the establishment of the European Qualifications Framework for Lifelong Learning, 2008). Weinert (1999) identifies several aspects affecting the development of competences: ability, knowledge, understanding, skill, action, experience and learners' motivation. He also distinguishes between the subject specific outcomes, those that refer to the subject discipline and the knowledge and/or skills specific to it; and generic outcomes, or generic/transversal skills, those that refer to any and all disciplines (1999). Generic/Transversal skills or "key competences" blend knowledge with the skills and attitudes necessary in a variety of real-life contexts for independent and life-long learning and are fundamental in helping students acquire, construct and apply knowledge to face complex challenges of the $21^{\text {st }}$ century (KeyCoNet, 2012).

According to the latest OECD review of Latvia's labour market policy setting (OECD, 2016), there is a shortage of skilled workers entering new market, and the European jobs network EURES (EURES, 2017) confirms that there is a substantial number of unemployed people in Latvia with low qualifications while Latvian employers, in contrast, emphasize the need of qualified employees with higher education, social skills, computer skills, a good command of Latvian, and the knowledge of foreign languages (Russian and English). Besides, there is a demand on Latvian labour market for adaptable and competent workers who possess both specific occupational, in addition to general skills (such as languages, and managerial skills), as well as transversal skills (the ability to think critically, take initiative, use digital tools, solve problems and work collaboratively - TS2020) (EURES, 2017). Consistent with the OECD Skill for Jobs Skill Needs Indicators (2017), in Latvia there is a shortage of the following skills: critical thinking, problem-solving, decision-making, active learning, reading comprehension, writing, speaking, persuasion, systems evaluation and analysis, negotiation, 
personal resources management, technology design, social perceptiveness, time management and others.

Moreover, according to the forecasts of the Ministry of the Economy of Latvia (EURES, 2017), it is estimated that in 2022, around $8 \%$ of new specialists with the necessary qualifications in their field will have a job that does not match their education, and if the education system does not undergo any transformations, this contradictory situation will develop, which, respectively, indicates that the knowledge acquired at schools is theoretical and fragmental, while more practical knowledge is required by the labour market. This means that more practical, non-formal methods should be introduced in formal education, which calls for the implementation of a new approach to education.

Since the new education model introduced within the project School 2030 highlights the necessity for the learning process to be competence-, project-, task-based and interdisciplinary, both collaborative and individualized, both learner and teacher-led and technologically innovative (Skola 2030), the development of transversal skills as the learning outcome put forward by the School 2030 project can be incorporated into a web/ project-based inquiry-oriented activity by means of WebQuests.

WebQuests or Web-based Projects are an inquiry-based lesson formats developed using various applications, which, in turn, assist in mastering the ways of technology application when given real-world tasks. As a result, students develop the skills necessary to become modern global citizens (Bell, 2010). WebQuests being both web-based and inquiry-oriented are seen as a perfect tool for development of transversal skills in the context of competency-based education implementation in schools. WebQuests have a potential to facilitate academic achievement and are regarded as the best fit for addressing the issue of a much needed transformation in education process with a final goal to connect the learning process to real life.

\section{Research Methodology}

To explore the ways and forms for integrating web-based inquiryoriented projects in foreign language teaching within the $21^{\text {st }}$ century perspective, the action research was conducted aiming to find out whether the involvement in web-based inquiry-oriented projects enhances secondary school students' transversal skills. The action research approach was found effective to "solve a problem of local concern (the skill gap) and to intervene in order to bring changes and improvements to educational practice (within the School 2030 perspective)" (Burns 2010: page for a quote).). The focus of the research was practical, directed at the teacher's 
practice, learners' achievement and the assessment of the value of the approach being implemented (Kemmis \& McTaggart, 1988).

The study was carried out in one of Riga secondary schools. Forty students of Forms 10 (upper-intermediate level of English proficiency) and 11 (advanced level of English proficiency) have formed the sample of the research. The convenience sampling -non-probability sampling, where participants were selected based on naturally occurring groups conveniently available to participate in the study was applied in the research framework (Nunan, 1992). The research has been implemented over the course of one term - spring term of the 2017-2018 School Year (5 months). The students were informed of the project and were given the choice to participate or not.

Six WebQuests were developed for the research needs. Given that within the research framework, all 6 WebQuests on different topics were developed and piloted during the research implementation period, each student was given 18 opportunities to apply the transversal skills in practice, reflect on them, and raise the awareness of his/her own skill proficiency.

Within the research framework, the existing traditional model of a WebQuest suggested by Dodge (1997) was elaborated. The following table introduces the revisions made:

\begin{tabular}{|c|c|c|}
\hline & \multirow{2}{*}{$\begin{array}{l}\text { Modified for } \\
\text { Transversal Skills' } \\
\text { Development }\end{array}$} & Revised Design \\
\hline & & Homework/Self-access \\
\hline \multirow{3}{*}{$\begin{array}{l}\text { Typical } \\
\text { WebQuest } \\
\text { Structure } \\
\text { (Dodge, B., 1995) }\end{array}$} & Welcome & \multirow{2}{*}{$\begin{array}{l}\text { Contextual - Course/ } \\
\text { Curriculum/Career-oriented }\end{array}$} \\
\hline & Preparation & \\
\hline & \multirow{2}{*}{ Introduction } & Open search allowed \\
\hline \multirow{2}{*}{ Introduction } & & Prior-knowledge activ. \\
\hline & Warm-up & Self-reflection/Feedback \\
\hline Task & Tasks & Web 2.0 Tools \\
\hline Process & Process & Evaluation: \\
\hline Resources & Product & - Individual/Group \\
\hline Evaluation & Reflection & - Process/Product \\
\hline Conclusion & Evaluation & $\begin{array}{l}\text { - Presentation } \\
\text { - Language }\end{array}$ \\
\hline
\end{tabular}

Figure 1. Modified WebQuest Structure for Transversal Skills' Development

Thus, the revised WebQuest Design introduced a nine-step model which allowed to identify the level of students' experience in the application of transversal skills before the project implementation, allowed prior knowledge 
activation and supported in learning how the project implementation has fostered the transversal skills' acquisition. It also endorsed the open search, rather than just the pre-selected links for the students to follow and students' self-access which fostered more autonomous learning and incorporated Web 2.0 tools.

The methods of data collection utilized in the research were: observation, student self-evaluation and feedback, student questionnaires, rubrics, performance-based assessments, authority assessment, notes of field experiences, documents and records.

\section{Findings and Discussion}

Before doing the WebQuests, in order to activate their prior knowledge on the subject, the target students were asked to answer 11 questions, e.g. What do I already know on the subject? What am I going to do? What are my goals? What would I like to learn from the project? What kind of skills do I already have to reach my goals? etc. The data obtained revealed that this type of activity was new for the target groups of students and they lacked the skills to perform the setting-the-goals task. Although the majority of students managed to set their goals for the particular lesson, the teacher's supervision and additional guidance was required. Students clearly revealed their ability to provide information about the topic and discuss it with their peers. All of the students were able to speculate about further activities. The skills the students mentioned as the ones they would utilize when doing the project were computer skills, pair-work, collaborative learning, critical thinking, communication, inquiry, writing and language skills.

In order to learn about their previous experience in the application of transversal skills, the students filled in the questionnaire which indicated that the majority of students find digital literacy, communication/collaboration and autonomous learning important personally, for the secondary school and future work practice. They also have indicated their ability to execute these skills as 'sufficient'. However, more than half of the respondents have indicated the insufficient level of the ability to execute information literacy skill and have stated that they lack creativity and innovation skills. However, they find these skills being 'important' personally both at school and for their future.

The data obtained revealed that target groups of students were able to activate their prior knowledge on the subject when doing the WebQuests and to indicate the transversal skills needed to complete the projects. They were also able to select the skills required at school and those required for their future. The target students also identified their previous experience applying the selected transversal skills. 
Having completed the web-based projects, the students were required to provide feedback and complete self-evaluation checklists. The analysis of the students' responses revealed that the majority of target students who were able to set their goals before the project had managed to accomplish their goals fully, others had stated to accomplish their goals partially. They mentioned that they could have produced better presentations and made fewer grammar/spelling mistakes, as well as that they could have made a deeper inquiry on the subjects. As the key benefits, students highlighted successful group work, liaising with their peers, new information learned, home-assignment, presenting and inquiry. The drawbacks the students identified were some technical issues, failure of some group mates to complete the task and the need to support them for the group benefit, analyzing and selecting the information required. Information evaluation and systematization were also identified as the most challenging skills by the majority of students. The most significant learning outcomes mentioned were broadening the horizons, presentation, team-work and the ability to do the inquiry. The students admitted that they would apply new knowledge in their future work and life when travelling or at work, when cooperating with others and planning their work. The target students found information search and analysis, as well as peer support and prior knowledge and skills useful in their project work and what helped them learn. In addition, the students pointed out that in the future, when doing another WebQuest, they would try to manage their time more efficiently, become better at information analysis and more responsible team mates. The students also stated that they would be more efficient at planning their work. The recommendation for the teacher was to organize web-based project work more often.

The self-evaluation checklists completed by the target groups of students revealed the level of transversal skills acquisition upon the completion of the projects. The skills the majority of students found personally important for the secondary school and future work practice and sufficiently proficient at were - digital literacy, communication/collaboration and autonomous learning.

The analysis of the self-evaluation checklists showed that the majority of students measured their level of communication/collaboration skills mastery upon the completion of the projects as 'proficient' and had marked the mastery of autonomous learning skill at the same level. The target students demonstrated their ability to communicate/collaborate efficiently using ICT, to obtain and organize information using digital tools, to create and share content using ICT within their groups and in class, were able to use ICT autonomously, were able to perform tasks and solve problems using ICT, to organize data and create digital texts to come up with 
the final product. The students' feedback and the teacher's observation showed that the students confirmed their digital literacy skill mastery the majority of the target students indicated being sufficiently proficient at. The information literacy skill, which was indicated by students as necessary to be more developed, appeared to be perceived by more than half of the respondents as progressing. Furthermore, the target students demonstrated the progress at the level of creativity and innovation skill mastery, the students perceived being not sufficiently skilled at during the initial stage of the project implementation. The majority of students marked the attainment level of creativity and innovation skill as developing upon the project completion, rather than not sufficient.

Based on the data obtained applying observation as a data collection method, the conclusion can be drawn that the students demonstrated the ability to interact, collaborate to achieve collective and personal goals, to communicate, express opinions, write, make oral presentations and perform using appropriate language, to show interest in global challenges, to implement ideas and take action based on critical evaluation of options and alternatives and to use digital tools when collaborating with others to create materials and share information with the peers (Collaboration and Communication Level 3, ATS 2020 Project) and proved to be able to access and evaluate information and communication technology, to use and manage information online, to create media products, to perform and complete their tasks utilizing digital tools effectively (Digital Literacy Level 3, ATS 2020 Project).

The evaluation rubrics (both process- and product-oriented) was used to assess students' individual and group performance, as well as the final product, task achievement and language input. The rubrics apportioned 20 points for Group Work, 20 points for the students' Individual Input, 20 points for their Presentations, 20 points for the Task Completion and finally, 20 points for the Language, making up a 100-point scale. The target students demonstrated excellent results: $90 \%$ of students (36 out of 40) gained 95 points out of 100 , having received 15 points out of 20 for the language; $5 \%$ of students ( 2 out of 40 ) performed quite well, getting 90 points out of 100 , having received 10 points out of 20 for their individual input, and $5 \%$ of students received the highest mark -100 points.

\section{Conclusions}

Since, the learning activities should be purposefully developed to enable the students to utilize the transversal skills which they would be able to transfer into their real-life contexts (ATS2020 Final Conference), the WebQuests implemented with target students had been specifically 
designed for the students so that they could demonstrate those skills and offered them the opportunity to gain crucial skills that would open up a world of possibilities. Taking part in collaborative and individual opportunities, the students were empowered with the knowledge and skills that were required for success beyond high school.

Students' observation revealed that the groups were actively involved in the project tasks, they had learned to collaborate successfully reaching common aims, they were learning from the process, demonstrated creativity and high level of participation having acquired new knowledge and skills critical to success in studies and life. Based on the analysis of students' performance (rubrics) and students' feedback, as well as their peer feedback, it can be concluded that current technology applications used in the classroom had positive effects on student learning. The students had demonstrated the ability to utilize the transversal skills, felt being exposed to the global issues and learned to draw out links and reflect. The WebQuests implemented are a good example of the new curriculum as they develop $21^{\text {st }}$ century skills, such as critical-thinking, problem-solving, synthesizing of information, research skills, self-direction, planning, selfdiscipline, initiative, creativity, teamwork, presentation skills etc.

\section{References}

Adam, S. (2004). Using Learning Outcomes. United Kingdom Bologna Seminar, HeriotWatt University, Scotland [online]. Retrieved from http://www.aic.lv/bolona/Bologna/ Bol_semin/Edinburgh/S_ADam_back_pap.pdf [accessed 21 January, 2018].

ATS2020 Project. The Assessment of Transversal Skills 2020 (2015-2018). EU [online]. Retrieved from http://www.ats2020.eu/ [accessed 09 November 2017].

Barton, D., Farrell, D., Mourshed, M. (2013). Education to Employment: Designing a system that works. McKinsey Center for Government [online]. Retrieved from https:// www.mckinsey.com/ /media/mckinsey/industries/social\%20sector/our\%20insights/ education $\% 20$ to $\% 20$ employment $\% 20$ designing $\% 20$ a $\% 20$ system $\% 20$ that $\% 20$ works/ education $\% 20$ to $\% 20$ employment $\% 20$ designing $\% 20 \mathrm{a} \% 20$ system $\% 20$ that $\% 20$ works.ashx [accessed 10 December 2017].

Bell, S. (2010). Project-Based Learning for the $21^{\text {st }}$ Century: Skills for the Future. Routledge Taylor \& Francis Group, LLC [online]. Retrieved from http://www.huso.buu. ac.th/file/2559/ActiveLearning/Document/10.ProjBL\%20of\%2021st\%20cent\%20skills. pdf [accessed 01 December 2016].

Burns, A. (2010). Doing Action Research in English Language Teaching: A Guide for Practitioners. NY: Routledge [online]. Retrieved from https://books.google.lv/ books?id = fjGMAgAAQBAJ [accessed 10 January 2018].

Dodge, B. (1997). Some Thoughts about Webquests [online]. Retrieved from http:// webquest.org/sdsu/about_webquests.html [accessed 01 December 2016].

EURES (2017). European Jobs Market - Labour Market Information in Latvia [online]. Retrieved from https://ec.europa.eu/eures/main.jsp?catId $=2776 \&$ acro $=1 \mathrm{mi} \& l a n g=e n \&$ 
countryId $=$ LV\&regionId $=$ LV0\&nuts2Code $=$ null\&nuts3Code $=$ null\&regionName $=$ Natio nal\%20Level [accessed 14 January 2018].

Kemmis, S., and McTaggart, R. (Eds.). (1988). The Action Research Planner. $3^{\text {rd }}$ edition. Geelong: Deakin University Press [online]. Retrieved from https://books.google.lv/ books? id $=$ GB3IBAAAQBAJ\&printsec $=$ frontcover\&dq $=13 . \% 09$ Kemmis, + S.,+ and + Mc Taggart, + R. + (Eds.). + (1988). + The + Action + Research + Planner\&hl $=$ en\&sa $=$ X\&ved $=$ 0ahUKEwj8xqf8us7YAhVEhaYKHX8aChIQ6AEIKDAA\# $\mathrm{v}=$ onepage $\& \mathrm{q}=13 . \% 09 \mathrm{Kemm}$ is \%2C\%20S.\%2C\%20and\%20McTaggart\%2C\%20R.\%20(Eds.).\%20(1988).\%20The\%20 Action\%20Research\%20Planner\&f $=$ false [accessed 10 January 2018].

Nunan, D. (1992). Research Methods in Language Learning. Cambridge: Cambridge University Press [online]. Retrieved from https://books.google.lv/books?id = qheTAgAAQBAJ\&lpg = PP1\&dq = Nunan\%2C\%20D.\%20(1992).\%20\%20Research\%20Methods\%20in\%20 Language\%20Learning\&pg $=$ PR4\#v $=$ onepage\& $q=$ Nunan,\%20D.\%20(1992).\%20\%20 Research\%20Methods\%20in\%20Language\%20Learning\&f $=$ false [accessed 10 January 2018].

OECD (2017). OECD Handbook for Innovative Learning Environments Paris: Publishing [online]. Retrieved from http://www.oecd.org/edu/the-oecd-handbook-for-innovativelearning-environments-9789264277274-en.htm [accessed 08 November 2017].

OECD Reviews of Labour Market and Social Policies: Latvia 2016 (2016). ISSN: 20743408 [online]. Retrieved from http://www.keepeek.com/Digital-Asset-Management/ oecd/social-issues-migration-health/oecd-reviews-of-labour-market-and-socialpolicies-latvia-2016/a-more-productive-labour-force-in-latvia_9789264250505-7-en\# . WlZgoq6Wbcs\#page2 [accessed 10 January 2018].

OECD Skills for Jobs - Skill Needs Indicators (2017) [online]. Retrieved from https:// www.oecd.org/els/emp/skills-for-jobs-LVA.pdf [accessed 10 January 2018].

Recommendation of the European Parliament and of the Council - Glossary, on the establishment of the European Qualifications Framework for lifelong learning (2008) [online]. Retrieved from http://www.eucen.eu/EQFpro/GeneralDocs/FilesFeb09/GLOSSARY.pdf [accessed 10 January 2018].

School 2030. Projekts Kompetenču pieeja mācību saturā. VISC. 2016-2021 [online]. Retrieved from https://www.skola2030.lv/ [accessed 09 November 2017].

Terminology of European Education and Training Policy (2014). Second Edition. Luxembourg: Publications office of the European Union [online]. Retrieved from http:// www.cedefop.europa.eu/EN/Files/4117_en.pdf [accessed 15 December, 2017].

Weinhert, F. (1999). Concepts of Competence. OECD's Definition and Selection of Competencies (DeSeCo) Project. Germany: Max Planck Institute for Psychological Research [online]. Retrieved from http://citeseerx.ist.psu.edu/viewdoc/download?doi $=$ 10.1.1.111.1152\&rep $=$ rep1\&type $=$ pdf [accessed 21 January, 2018] . 


\title{
PROFESSIONAL IDENTITY FORMATION PROCESS OF A DANCE TEACHER
}

\begin{abstract}
In the modern society the concept of professional identity is topical in many different occupations. The professional identity of the dance teacher has not been researched scientifically and there are no studies about this concept. The article focuses on the formation process of the dance teacher's professional identity as well as the professional identity model. The aim of this article is to view the professional identity formation process in a profession of a dance teacher and to create a professional identity model of the dance teacher by analysing scientific literature and using professional experience. The professional activity of the dance teacher directly affects the students in any age group from toddlers to seniors, both physically and psychologically; therefore, it is especially important to pay attention to the issues of dance teacher's professional identity, or even the lack of information about the professional identity itself. If the questions of professional identity are not discussed in the study process and there are no related instructions or materials that reveal the essence of the professional identity concept in the world of dance, then the knowledge gained in higher education and practice can be interpreted as unnecessary for the profession. As a result of this study there is formed a professional identity model of a dance teacher. Explaining professional identity leads to greater insight into one's profession, as well as quality assessment of one's professional work and achievements.
\end{abstract}

Keywords: dance pedagogy, dance teacher, professional identity, professional identity model.

\section{Introduction}

In the fast rhythm of the today's society and in the wide range of opportunities there are more people that spend great deal of their spare time in their workplace, or even, as they say, "bring work home". It is necessary for people to know and understand their identity, to follow the goals, and not less to have a greater insight in professional identity. 
Palmer (2016) states that studies on professional identity consider not only what teachers know and/or believe but also who they are, how they view themselves as teachers, how they relate to students, how they deal with problems, how they reflect on issues, and how they identify themselves within the profession.

In the creative industries there is a thin line between the work hours and spare time. These professions are more like a way of life than just a job. Before a class, dance teacher forms new exercises, searches for a new musical material, review the structure of the future lesson, creates new choreography and other necessary things for a successful dance class. After work a dance teacher designs dance costumes, promotional materials and gets in contact with the specialists from other professions to organize the concert activities. Styrke (2015) affirm that in a time of constant change, dance teaching certainly deals with changing didactic conditions, curricular as well as contextual and social.

In the profession of a dance teacher the higher education gives a specific additional knowledge, but not a basic one. Similarly music students practice even before entering elementary school, to be ready for their profession. Upcoming professionals in the art of dance also must be educated in dance from childhood before entering higher education. In Latvia there is a lack of professional art schools where youth can learn different dance skills as a future professionals. There are only some private dance studios that are accredited as schools, but mainly a profession of a dancer is either obtainable in the Riga Choreography High School, or is in a level of additional after class studies.

With a problem like this, there are even more reason to look in the direction of professional identity formation and its content, to understand a way the teachers feel and how they perceives their profession in a society where dance is only a way to spend ones free time and get fit, but not as a serious profession which requires education and non-stop development.

\section{Methods and Materials}

In this article the main emphasis concerning the research methods is the analysis of scientific literature. The topic of professional identity is still opened for new research and there are variety of discussions about methods of research and especially the content of professional identity.

In the framework of this study the concept of identity was reviewed from philosophical point of view. The course of the study of Identity and Professional Identity gained a phenomenological set. Researching the concept of professional identity the author encountered researches of the following authors: A. Spona, M. Vidnere, J. Jermolajeva, J. Jakovleva, 
M. J. Fernandez Gonzales, A. Griffin, D. Beijaard, G. J. Knowles, J. Nias, N. Verloop and others. Selecting the required scientific literature, the author of this study used such databases as: WEB of science, EBSCO, APPA gold, SCOPUS, Science Direct. There were revised a list of dissertations from 2010 till 2017, but as the necessary information was insufficient the limitations in time were cancelled. The keywords were "identity", "professional identity", "teachers professional identity", "dance teachers professional identity", "dance teacher", "dance pedagogy". From the gained results the researcher selected 25 articles, 9 doctoral dissertations about remotely close topics in dance, sports, music, pedagogy and 2 dissertations about professional identity. None of the selected sources (using the mentioned key words) did not offer any researches about professional identity of a dance teacher. The closest topics to the selected concept were "teachers professional identity", "professional identity integration of a music teacher and performer".

As there is no scientifically based information about dance teachers professional identity author of this article researched literature on the topic "teachers professional identity".

Beijaard, Meijer, Verloop (2000) investigated experienced secondary school teachers' current and prior perceptions of their professional identity. In their research of teachers' perceptions of professional identity, authors explored the way teachers derived their professional identity from (mostly combinations of) the ways they saw themselves as subject matter experts (Hoyle, John, 1995; Bennett, Carre, 1993; Calderhead, 1996), pedagogical experts (Beijaard, 1995; Damon, 1992; Oser, 1992), and didactical experts (Beijaard, 1990; Doyle, 1990; Vermunt, 1995). In European studies and teaching practices, these are common concepts to indicate what a teacher should know and be able to do (Beijaard, Meijer, Verloop, 2000).

The concept of identity is defined in various ways in the more general literature. It seems that the concept of professional identity is also used in different ways in the domain of teaching and teacher education (Beijaard, Meijer, Verloop, 2004). In some studies, the emphasis was placed on the roles that teachers take over in their professional work (Goodson, Cole, 1994; Volkmann, Anderson, 1998), whether or not in relationship with other concepts, or on concepts like reflection or self-evaluation that are important for the development of professional identity (Cooper, Olson, 1996; Kerby, 1991). In other studies, the concept of professional identity was related to the images of self (Knowles, 1992; Nias, 1989). It was discussed that these concepts or images of self strongly determine the way teachers teach, the way they develop as teachers, and their attitudes toward educational changes. Furthermore, professional identity refers not only to the influence of the conceptions and expectation of other people, including broadly accepted images in society about what a teacher should 
know and do, but also what teachers themselves find important in their professional work and lives based on both their experiences in practice and their personal backgrounds (Tickle, 1999).

In 2004 Beijaard, Meijer and Verloop conducted another research of the literature on teacher's professional identity to the period 1988-2000, because it was in this period that teachers' professional identity emerged as a research area. All together there were analysed 22 studies relevant to the topic. Concerning teachers' professional identity formation, the authors conclude that teacher's biographies and beliefs that are determined by these biographies are conceived of as important constituents of teachers' professional identity formation (Beijaard, Meijer, Verloop, 2004). The research on teachers' professional identity formation also contributes to understanding and acknowledgment of what it feels like to be a teacher in today's schools, where many things are changing rapidly, such as - teaching methods, movement techniques, emerging and combining dance styles, contemporary view on choreography, new technology, and how teachers cope with these changes. In addition to this fact Beijaard, Meijer and Verloop (2004) pay attention to the teacher's personal part of professional identity and that inner conflict can lead to friction in teachers' professional identity in cases in which the 'personal' and the 'professional' are too far removed from each other.

There are three main factors that influence the definition of teacher's professional identity:

- Professional identity is not a stable entity; it cannot be interpreted as fixed or unitary (Coldron, Smith, 1999). It is a complex and dynamic equilibrium where professional self-image is balanced with a variety of roles teachers feel that they have to play (Volkmann, Anderson, 1998);

- Cooper and Olson (1996) pointed to the fact that professional identity is multifaceted. Historical, sociological, psychological, and cultural factors may all influence the teacher's sense of self as a teacher. Furthermore, professional identity may consist of many subidentities that may conflict or align with each other (Mishler, 1999);

- A final remark pertaining to the definition of professional identity concerns the emphasis on the 'personal' and an underestimation of the contextual side that plays a part in professional identity formation. Reynolds (1996) emphasized that what surrounds a person, what others expect from the person, and what the person allows to impact on him or her greatly affect his or her identity as a teacher.

Most recent researches (Olsen, Buchanan, 2017) state that professional identity is not only the ongoing process of a teacher continually relying on his or her self-understandings to make meaning out of present experience 
but is also the resulting, dynamic product of knowledge, goals, and selfunderstandings that is enacted in everyday practice.

Thomas and Mockler (2018) argues that in the same way as it appears that professional identity cannot be framed in terms of professional knowledge, neither can it be framed in terms of experience in the way Beijaard, Meijer and Verloop contend. Thrue the wide discussions within the research Thomas and Mockler (2018) suggest that teachers' subidentities interplay in a complex way in the formation of their professional identities.

Looking up the experience in Latvian scientific researches there are several doctoral dissertations on the concept of professional identity. Jakovleva (Jakovleva, 2009) analyzed identity theories concerning professional identity. Fernández González (2012) analysed performer and teacher identity integration in the pedagogical work of musical instrument performer students.

Estimating the person's identity and professional identity formation process, Fernández González (2012) developed professional identity formation process model, which includes person's psychological, actual and social aspects of profession: formation of the ideal image of professional; choosing a profession; involvement in professional activity and personal and social recognition.

Spona, Vidnere and Jermolajeva (Професиональная идентичность neдагога, 2016), in the collective monography on teacher's professional identity in higher education institutions (Riga - Latvia, Smolensk - Russia), promote the following professional identity components: professional philosophy; professional knowledge and skills; professional roles; interaction with colleagues; professional representation. A part of the authors of this monography proposed to include in the model such components as: endurance and tolerance. Besides, they suggested to create an outer circle of secondary components which affect professional identity.

\section{Results and Discussions}

As a result of scientific literature analysis and using professional practice and experience in the field of dance pedagogy there is developed a professional identity model of a dance teacher (see Figure 1).

This model consists of professional identity components and they form a core circle. The components are professional philosophy and values. The values are a basis of professional activities and life in general. Professional philosophy consists of beliefs, goals of professional work, professional ethics, the most important notions about the profession; professional knowledge and skills that are obtained not only in the higher education 
but also in the early dance education; professional roles can vary, including an educator, teacher, choreographer, dancer, organizer of events and manager. There can be primary roles in a daily work and secondary roles that are useful to engage properly in the profession; artistically creative work is an innovative component. The work of an art teacher including a dance teacher cannot be cut off from creativity and artistically creative work which results in a work of art - a dance; professional attitude towards work presents an attitude towards the profession itself and promotes such terms as suitability for the profession, values and cultural behaviour; image of the professional. In the world of dance there is a certain image that society awaits from a dancer and a dance teacher. The image promotes not only a certain behaviour but also appearance. Considering the teacher himself - the image can vary from a friend to a highly trained professional.

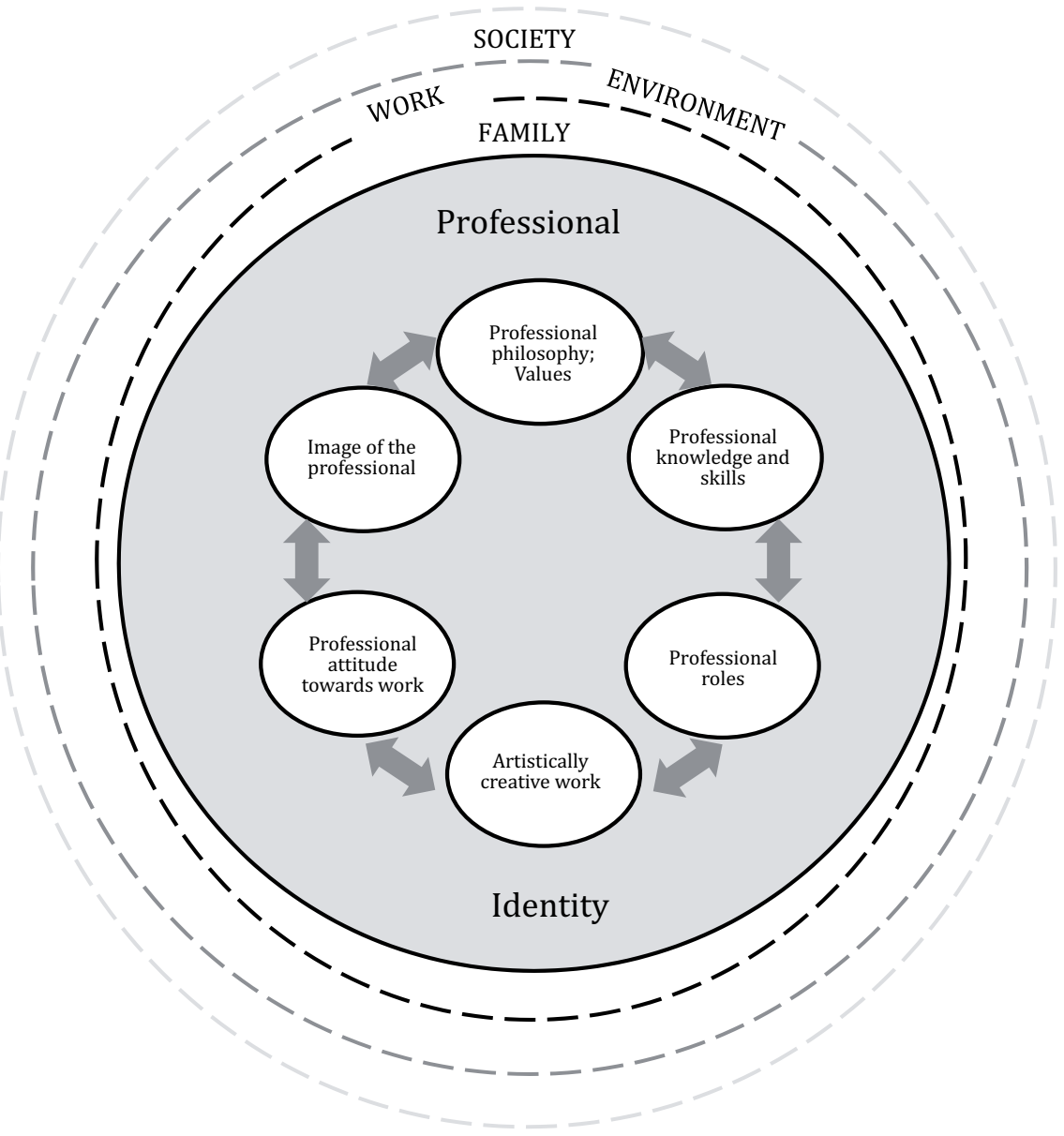

Figure 1. Professional identity model of a dance teacher 
Outer circles represent outer influence factors that affect dance teacher's professional identity. First of all, a family can greatly influence professional identity of an artistic profession. Professions which represent different forms of art are a way of life and thinking. Spare time overlaps with work frequently, the artistic and concert activities take place on weekends or even on holidays and celebration, therefore a supportive family attitude can promote professional identity and vice versa. Work environment is another important factor of influence in every profession - supportive work colleagues/boss, pleasant dance hall, appropriate salary/pay, appreciation and helpfulness if necessary. Society can influence professional identity in terms of prejudice, incorrect notion about the profession, incomprehension, but also recognition, appreciation.

\section{Conclusions}

- Professional identity is an ongoing process that changes over the time and under different circumstances.

- Professional identity is an open and topical subject to be discussed, especially in the field of dance pedagogy, because there are no related researches publicized and available on this topic.

- Dance teachers professional identity formation process should be traced back to early childhood experience.

- There are variety of methods to apply on measuring the professional identity of a dance teacher sarting from a survey to bibliographical stories.

- The content of professional identity may change according to the selected profession.

- Professional identity of a dance teacher consists of professional philosophy and values, professional knowledge and skills, professional roles, artistically creative work, professional attitude towards work and image of the professional.

- Artistically creative work is an important component of professional identity of a dance teacher and is essential to their professional activity.

- Society, family, work environment are the main outer factors that influence dance teachers professional identity.

- It is necessary to include the topic of "Professional Identity" into the curriculum of higher education of dance teachers/choreographers to create greater insight into one's profession, as well as quality assessment of one's professional work and achievements. 


\section{References}

Beijaard, D. (1990). Teaching as acting: A reconstructive study of an action theoretical approach to research and development in the domain of teaching. Wageningen Agricultural University: Department of Education.

Beijaard, D. (1995). Teachers' prior experiences and actual perceptions of professional identity. Teachers and Teaching: Theory and Practice, 1, 281-294.

Beijaard, D., Meijer, P. C., Verloop, N. (2000). Teachers' perceptions of professional identity: an exploratory study from a personal knowledge perspective. Teaching and Teacher Education, 16, 749-764.

Beijaard, D., Meijer, P. C., Verloop, N. (2004) Reconsidering research on teachers' professional identity. Teaching and Teacher Education, 20, 107-128.

Bennett, N., Carre, H, J. C. (1993). Learning to teach. London: Routledge.

Calderhead, J. (1996). Teachers: Beliefs and knowledge. In: D. C. Berliner, \& R. C. Calfee, Handbook of educational psychology (pp. 709-725). New York: Macmillan.

Coldron, J., Smith, R. (1999). Active location in teachers' construction of their professional identities. Journal of Curriculum Studies, (31)6, 711-726.

Cooper, K., Olson, M. R. (1996). The multiple \&I's' of teacher identity. In: M. Kompf, W. R. Bond, D. Dworet, \& R. T. Boak, Changing research and practice: Teachers + professionalism, identities and knowledge (pp. 78-89). London: Falmer Press.

Damon, W. (1992). Teaching as a moral craft and developmental expedition. In: F. K. Oser, A. Dick, \& J. L. Patry, Effective and responsible teaching (pp. 139-153). San Francisco: Jossey-Bass.

Doyle, W. (1990). Themes in teacher education research. In: W. R. Houston, Handbook of research on teacher education (pp. 3-23). New York: Macmillan.

Fernández González, M. J. (2012). Atskañotājmākslinieka un pedagoga identitāšu integrācija mūzikas instrumentu spēles studentu pedagoǵiskajā darbībā. Promocijas darbs pedagoóijā (Doctoral disertation). Rīga: Latvijas Universitāte.

Goodson, I. F., Cole, A. L. (1994). Exploring the teacher's professional knowledge: constructing identity and community. Teacher Education Quarterly, 21(1), 85-105.

Hoyle, E., John, P. D. (1995). Professional knowledge and professional practice. London: Cassell.

Jakovḷeva, J. (2009). Profesionālā identitāte profesijas apguves sākumposmā. Promocijas darbs sociālajā psiholog̣ijā (Doctoral disertation). Daugavpils: Daugavpils Universitāte.

Kerby, A. (1991). Narrative and the self. Bloomington: Indiana University Press.

Knowles, J. G. (1992). Models for understanding pre-service and beginning teachers' biographies: Illustrations from case studies. In: I. F. Goodson, Studying teachers + lives (pp. 99-152). London: Routledge.

Mishler, E. G. (1999). Storylines: Craft artists' narratives of identity. Cambridge, MA: Harvard University Press.

Nias, J. (1989). Teaching and the self. In: M. L. Holly, \& C. S. McLoughlin, Perspectives on teachers + professional development (pp. 155-171). London: Falmer Press.

Olsen, B., Buchanan, R. (2017). Everyone wants you to do everything: Investigating the professional identity development of teacher educators. Teacher education quarterly, Winter 2017, 9-34. 
Oser, F. K. (1992). Morality in professional action: A discourse approach for teaching. In: F. K. Oser, A., Dick, and J. L., Patry, Effective and responsible teaching (pp. 109-125). San Francisco: Jossey-Bass.

Palmer, H. (2016). Professional primary school teacher identity development: a pursuit in line with an unexpected image. Teacher development, 20(5), 682-700.

Profesional'naja identichnost' pedagoga:sravnitel'noe mezhdunarodnoe issledovanie (2016). N. P. Senchenkova, A. P. Shpona (Eds.). Smolensk: SmolGU, 2016.

Reynolds, C. (1996). Cultural scripts for teachers: Identities and their relation to workplace landscapes. In: M. Kompf, W. R. Bond, D. Dworet, \& R. T. Boak (Eds.), Changing research and practice: Teachers' professionalism, identities and knowledge (pp. 69-77). London, Washington, DC: The Falmer Press.

Styrke, B. M. (2015). Didactics, dance and teacher knowing in an upper secondary school context. Research in dance education, 16(3), 201-212.

Thomas, M. A. M., Mockler, N. (2018). Alternative routes to teacher professional identity: Exploring the conflated sub-identities of teach for America Corps Members. Education policy analysis archives, 26(6).

Tickle, L. (1999). Teacher self-appraisal and appraisal of self. In: R. P. Lipka, \& T. M. Brinthaupt, The role of self in teacher development (pp. 121-141). New York: State University of New York Press.

Vermunt, J. D. (1995). Process-oriented instruction in learning and thinking strategies. European Journal of Psychology of Education, 10, 325-349.

Volkmann, M. J., Anderson, M. A. (1998). Creating professional identity: Dilemmas and metaphors of a first-year chemistry teacher. Science Education, 82(3), 293-310. 


\title{
THE LANGUAGE JUNGLE: SPEECH TRAINING IN A NATURAL LEARNING ARENA
}

\begin{abstract}
The project presented is one in cooperation with Tusenbein (Centipede), our close partner preschool near Mo i Rana, a town in Northern Norway. Here they have constructed a climbing jungle in the woods not far from the preschool, where the children can work with social skills, bodily-kinesthetic skills, and linguistic skills; they call it the Language Jungle. As a teacher in preschool teacher training, it is important to learn more about what the preschools find necessary to work with, and the methodology incorporated. In order to learn more about this project, I have employed fieldwork methodology; spending time in the field, to learn more about how a climbing jungle can be an arena for speech training.
\end{abstract}

Keywords: Holistic learning, language training, Norwegian preschool.

\section{Introduction}

Tusenbein (Centipede) Preschool outside Mo i Rana in Northern Norway wishes to use the outdoor environment actively in its educational activities. Therefore, the staff has set up a climbing jungle in the woods a distance from the preschool. The staff does not want to merely work to stimulate motor development outdoors; they also want to work to link linguistic activities to the motor challenges. Hence the name Language Jungle.

The preschool has social skills, languages, and outdoor life as main areas of focus. "Outdoors, the children use their bodies and their senses differently than indoors" [author's translation] (Tusenbein, 2018). The outdoor arena is an arena for communication and interaction, an arena where the children must relate to each other and care about each other and learn to make their own choices. Thus, the three main areas of focus 
can be combined in the daily routines, and through the development of the Language Jungle be given an even clearer focus.

My role has been to evaluate the process of construction and implementation of the Language Jungle, using fieldwork methodology to uncover whether the preschool achieved its goal, and the staff succeeded in creating an environment outdoors where the children could develop both motor and language skills in a natural way.

\section{Method and design}

A climbing jungle is a playground made up from trees and apparatus, with built-up obstacles and challenges that invite the children to explore, climb, balance, crawl, spin, hang, and do gymnastics; a jungle that is not impenetrable, but challenging and stimulating for children's sensory motor development. By stimulating the senses, the children acquire basic skills for body awareness and coordinative properties such as balance, coordination, speed and strength (Jagtøien and Hansen, 2000, pp. 71-77). Tusenbein's staff wanted to use their climbing jungle to give the children a varied environment where they must learn to interact and take each other into account, where they face challenges both in motor and language skills. “... if we manage to change practice in relation to language-stimulating tasks outdoors" [author's translation], is a learning outcome taken from an application for support for the Language Jungle project (Tusenbein, 2009). One of the goals of action learning or action research is precisely to create change or renewal in oneself or in an institution. "Action research is a very practical way of looking at your own work in order to check whether it is like you would like it to be" (McNiff 2005, p. 5). Action learning implies that a teacher asks questions about his or her own practice, and finds the answers him- or herself (Tiller, 2006, p. 52).

Action learning is what teachers do in their everyday lives, while action research is something a researcher brings in from outside and interacts with the people of the school on a daily basis (Tiller 2006, p. 29). I was invited into the project as a researcher, but this was not my project, so based on this definition, the project cannot be defined as action research. May Britt Postholm writes that there may be practitioners who initiate action research efforts based on their problem areas, and in order to establish this mutual relationship between researchers and research participants, she uses the term interactive action research. Postholm introduces this collective term for both action research and action learning (Postholm 2006, p. 13). The Language Jungle is the preschool's project, and it is their ideas that will be put into practice. To complete the project and achieve its goals, Tusenbein Preschool needs to change its practice and use the outdoor environment 
more consciously in language stimulation work. The Language Jungle project may thus be defined as interactive action research.

My role in the project described is that of the researcher to evaluate it, thus the evaluation research method is the chosen approach. Evaluation research is a method concerned with "exploring effects of different types of measures and influencing, changing or describing processes" (Sverdrup, 2002, p. 19). It has become a central area as a result of the need to investigate how a project progresses; it is about establishing experiences of effort and change. The survey undertaken is based on the preschool's own goals, and is an investigation of whether or not they have been achieved. The investigation is a qualitative survey in which method and design are defined based on the relevant issues.

The method used to collect data material in the Language Jungle project was fieldwork. On the basis of querying, listening, participating, and observing, the field researcher collects the required data material, which must then be interpreted and analysed (Hammersley and Atkinson, 2004, pp. 8-9). In order to get to know Tusenbein Preschool and to carry out research, the preschool and Language Jungle have been visited regularly throughout the project period, and also after the project period was over. My aim has been to observe the development of the project, and to observe how children interact and use language when playing in the Language Jungle. The field researcher seeks to see the world as the participators in the field see it; she takes part in the activities that take place, while observing what the various participants do, and collecting data by presence in the field studied. In this way, the field researcher tries to achieve the most naturalistic approach to the substance (Law, 2007, p. 30, Gubrium and Holstein, 1997, pp. 24-25).

An insight into a developing process has been obtained through the important tools of qualitative interviews and dialogue. By selecting interviewees with relevant competence of topic and project implementation, one may easier understand the informant's evaluation off the given topic (Sverdrup, 2002, p. 122). Planning an interview, it is important to clearly determine both contents and goals. Six Tusenbein employees were interviewed before the project was implemented, during the implementation, and finally after the project completion. The goals of the interviews were that informants on their own accord reflect over the language stimulation work taking place in the preschool's outdoor learning environment, their pre-project anticipations, what they learned during the project, and whether they are using the outdoor environment more consciously in language stimulation work after the project is finished.

In my work, I have used a logbook, where the observations and notes from conversations and interviews with both children and staff were duly 
noted along the way. As a researcher, I want to be close to the informants, while trying to be neutral enough to reflect on and find meaning in the information I receive (Vedeler, 2000, pp. 31-35). The data material for the evaluation research is my logbook, interview transcriptions, photos, children's drawings, and documents provided by the preschool.

Interpretations, assessments and reflections of the information gathered was the next step. "The first step in the analysis process is naturally a thorough reading (probably several times) of all the data to get to know them well" [author's translation] (Hammersley and Atkinson, 2006, p. 238). In connection with fieldwork, there will be a large amount of data that needs to be reviewed to search for relationships across the data. The goal is to identify key features and important findings that can illuminate the issues. Data analysis does not need to be a separate part of the research process; it takes place in parallel with data collection, and continues until writing reports, articles and books (Hammersley and Atkinson, 2006, p. 233).

In this article the focus will be on how Tusenbein Preschool manages to create an environment outdoors where the children can develop both motor and language skills in a natural way. I will also say something about what happened in the Language Jungle after the project period was over.

\section{The Language Jungle}

Tusenbein Preschool has three main areas of focus, where language is one. The term language training is preferably used for systematic and organized introduction to foreign languages and mother tongue written languages. However, the mother tongue is not something one acquires automatically either. Children need both language impulses and language help, which they receive to varying degrees; often without the adults being conscious about this. In 2005, Grøver Aukrust wrote a report about early language training commissioned by the Ministry of Education and Research. Here she explains that children's vocabulary show a relative stability from the age of six to the end of their education; in the way that the child, who has a small vocabulary when he or she starts school, also has a limited vocabulary when finishing school. On the other hand, the child with an extensive vocabulary when he or she starts school will continue to develop this and finish school with an even more extensive vocabulary and good reading skills (2005, p. 44). This stresses the importance of the preschools' work with speech training.

The other areas of main focus for Tusenbein are social competence, and outdoor activities. Growing children need to use their bodies; they need to develop their bodily-kinaesthetic or motor skills. Outdoors they can run faster, jump higher, climb higher, and play wilder. The children need 
to work with social competence; they must learn how to cooperate with each other, how to help each other, and to grow up to be a part of our community.

Nature is also a place to work with linguistic skills, as the children necessarily have to communicate when playing together. The child is more observant outdoors, where he or she pays attention and experiences the joy of discovery. Outdoors, the children build a concrete understanding of concepts, and they use their senses discovering the various things they come across: They taste, they touch, and they listen to; and this way they acquire the words and their meaning. Blueberries are sweet, nettles sting, moss is soft, the marsh is wet, and the bonfire is hot; and it might be slippery to balance on a wet log or walk on ice. These physical experiences ensure that the children learn new and appropriate language in a natural and meaningful context, where senses, emotions, and understanding are also stimulated. Communicative skills develop, as the children may need to do some research themselves to find the answers to their wonder; they need to argue, listen, and wait their turn. This way they learn about forms of communication, and by discussing and explaining, learn more about the world around them, as well as an increased conceptual understanding (Hilmo, Holter og Langholm 2006). Semiotic meditation is about the different cultural knowledge and valuables the child acquires through social practice. Everyday language and conversations is the central learning arena (Vygotsky 1978, Gjems and Løkken 2011, p. 49). It is important that the child is in an environment where language is used actively, thus acquiring new terms and phrases in a meaningful context. The playground is the child's natural learning arena. Through playing, the child discovers the world around, using language and body. This was the background for Tusenbein Preschool's decision to build a climbing jungle, where the children would face challenges both in motor and language skills, hence the name Language Jungle. Staff, parents, and children participated actively throughout the process. In the initial phase, it was ensured that some of the apparatus were completed, so that the children could play while construction continued. In this way, the preschool created a motivation for the children to visit the Language Jungle while it was still under construction.

When visiting the Language Jungle at this early stage, some of the children would want to play, while other children were actively involved in the work with the adults. The children helped to strip wood to be used in the construction of new apparatus, and they helped to carry stones away from the area. The children present during the construction period are able to test the apparatus under way, and may give immediate feedback on the functionality; as the five year old who stood watching the youngest children having problems climbing a somewhat steep hill: "It is easier for 
the smallest ones to enter from the other side, because it is easier to walk there. First we have to remove the twigs and branches". He then proceeded to remove the branches (personal observation, 2011). Children are solutionoriented; they see a problem and come up with constructive suggestions for how it may be solved. They put words to their thoughts and they explain what they mean. When the adults take the children seriously and listen to what they have to say, they help the children develop confidence in their own participation and problem solving. The children involved in such work gain experience in seeing different types of tools in use. They learn how to handle a sheath knife, they learn the names of tools not only because they have seen pictures of them, but because they know how they feel, how heavy they are, what they are used for, how they are used, how they sound, and they learn to respect dangerous tools; all due to that they have seen them in use.

At the same time as the apparatus in the climbing jungle were developed, some of the preschool teachers had the main responsibility for developing and testing language-stimulating equipment that would be used outdoors. Metal signs were set up around the Language Jungle, with accompanying magnetic photo cards with different types of tasks. Options may be cards with pictures of things that rhyme, geometrical forms, animals and their footprints, fairytale pictures, songs, numbers, letters, and numerous other activities. Boxes of physical objects to be used for tactile activities were assembled. All the senses that are important for learning, the visual, auditory, kinesthetic and the tactile, should be stimulated in the Language Jungle. In addition, this work was, and is, a common responsibility for the staff. On planning days, they have focused on language material through exchange of experience. The staff, teachers and assistants, are familiar with the activities through joint practical testing. It is up to the individual adult, both assistant and teacher, to further develop the ideas, and perhaps create new tasks to be implemented. The Language Jungle may also be used to make observations and mapping of certain children. This will guide the choice of tasks, but as all tasks have an element of play, any task may be fun and challenging to all children in the group. When the teachers use the equipment, they must reflect on what they do, how they use it, and how the children react to it. Here follows an observation made in the Language Jungle the summer of 2013:

The adult made three different tasks for a group of four four-yearolds to work with. Two of the boys immediately start working on a task on geometrical forms made up of colorful images. The adult talked a little about the names of the shapes and how to make figures with their help. The boys quickly move into a game involving 
the use of all the images to cover the background board. They have no wish to end this game, as they have figured out another way to do this activity. The adult goes to one of the hammocks and pulls out a task involving pictures from fairy tales. Using the pictures, the adult tells a story, while the children lie in the hammock listening. More children arrive, and soon fill the hammock. The children want to tell stories, and a girl has the first go; which works out well, with just a few interruptions by the input of others. "You may tell a story afterwards", says the girl who does not wish to be interrupted. This is fine for the other girl, as she afterwards tells the same story with new input from the listeners. It was time for food following this task, and there was time for no more tasks this session.

When the children cooperate retelling a story, they will together recreate more details and structure. The children that do not have so much to contribute with pay attention as listeners, learning the story from the others, and eventually will be able to tell the story themselves. Children working together solving a task, either they follow the instructions of the adults or their own, need to communicate, explain, and describe; thus, learning to cooperate and learn together.

In addition to organized activities, the language jungle invites nonorganized play and language activities. The apparatus form a trail where the children may climb, crawl, balance, and walk without putting their feet on the ground. A recurring tradition is games with rules, where many of the games are related to old traditions and customs the children have picked up from the adults or older children. The children also create their own performances and their own rules in the games, as in the following observation from the summer of 2010 :

Three boys climb around the jungle, with me on the ground watching. "You are the princess," a boy tells me. "Great," I answer before I understand it is not at all great. "You cannot come up until three minutes," he explains. It is the rule: touch the ground, then you will be a princess in this game; and then you have to wait a while before climbing up again.

Children learn a lot about communication and collaboration through games of rules, where they must explain, negotiate, and argue in advance of designing the rules for the game (Jagtøien and Hansen 2000, p. 152).

Between the trees, there are nets that form hammocks. The spaces of these hammocks or nets create a framework for role-playing with almost any theme, as in the following observation from the summer of 2011: 
Four boys, four and five years old, play animals in one of the hammocks.

"Once upon a time I was a cow," says Per.

"I was a baby cow", says Pål.

"Moo, moo, moo", says Per. "You were afraid of the large cow"

"I was an elephant," says Espen.

"No, you must be a tiger," says Pål.

"I can be an elephant," says Espen.

"But there can be only one cheetah," says Per. "Grr".

Some girls the same age are sitting in a nearby hammock. They would like to participate in the boys' game. They play women who live in the woods and are scared by the wild animals when they go for a walk.

Another time I visited, the nets were boats, with lava flowing underneath. The children had to be very careful not to fall on the ground and burn up. "From a language development perspective, role play is the most important form of play," says Anne Høigård [author's translation] (2013, p. 93). The role play is entirely dependent on the child's linguistic skills; it is the linguistic interaction between the children that carries the game. The children create a fiction together, and they must be able to perceive and follow the initiative of other children and take the initiative themselves (Høigård, 2013, p. 93).

In her doctoral dissertation, Lise Beate Estil highlights the important interaction between motor and linguistic competence, pointing to the importance of the playground for developing both motor and linguistic skills. While the youngest children learn languages from adults or older children, the play with their peers is the most important learning arena for the oldest children in the preschool. Children who have poor motor skills often experience difficulty being accepted as participants in play with other children. Similar problems are also reported for children who are inadequate in language skills. When children are excluded from interacting with other children, for either reason, this may have a negative effect on the development of both motor and language skills (Estil, 2002, p. 12). One affects the other, and thus the child is in a negative spiral. This spiral effect will also pose a social problem; the child will feel left outside, and so his or her social development is understimulated. The child may develop poor self-esteem, stay out of - or be held out of - the social community, which in turn leads to further delays in linguistic and motor development as well as social development (Løge, 2011, p. 12).

The Language Jungle is by no means complete, and is under continuous development. Since the staff built the jungle themselves, through their 
ownership they have a responsibility for maintenance and further development. Now, a few years later, much has happened in the Language Jungle; many of the old apparatus are strengthened, some are gone, and new ones have replaced them. The same applies to the language stimulation material, which is also work in constant development, depending on what is in focus at the preschool, and what ideas or needs are apparent.

The main subject of the interviews with the staff was which anticipations they had for the project before it started, and what they themselves think they learned during the project. Prior to the project, one of the informants was concerned that the activities in the Language Jungle might be run too much by the adults. After the project had ended, the informants were asked whether this was a current issue. All the informants responded with a no to the question, thus showing that the activities indeed are based on and carried out through play and joy. As adults in the preschool, it is important to appreciate the self-worth of play, and thus accommodate it. When asked what they have learned through the work on the project, there was a consensus that they have become much more aware of children's language development. They report that they have gained a greater focus on language and language stimulation; not only when they are in the Language Jungle, but in all daily tasks. They bring ideas and material from the Language Jungle, which are used in the preschool, or when they are on trips to other places. The staff get new ideas that are integrated into the ones they already have, and observation and language stimulation has become an even more natural part of everyday life. The staff at Tusenbein Preschool all agree that they have achieved their own goal of changing practice in relation to language-stimulating tasks outdoors.

\section{Conclusive comments}

Using fieldwork as a research method to evaluate the project Language Jungle, I have been able to establish that Tusenbein Preschool has reached its goals for the project. The starting point for this study was to look at how the preschool could create an environment outdoors where the children could develop both motor and language skills in a natural way. The Language Jungle facilitates for both planned, ad hoc, and in situ developing language activities, through the apparatus and accompanying tasks, which together form an integrated part of the climbing jungle. Early and good language stimulation is an important part of the preschool's content, and the playground is an important arena for developing both motor and linguistic skills (Estil 2002). Through the development of a challenging and exciting play area, they have created an arena that will be developing for the whole child; motoric, linguistically, intellectually, and also socially. 
The children have been given a challenging arena for play, where they first and foremost can play together and have fun.

While the project Language Jungle is about developing a good playground for the children, it is also about further development for the staff, both teachers and assistants, who have both created something and learned more about what work with language stimulation in preschool is. There is a consensus among the Tusenbein employees interviewed, that they were using the outdoor environment more consciously in language stimulation work after the project was completed, which was another goal for the project. Now, some years later, the project Language Jungle is in itself completed, but the Language Jungle is still in a continuous development, as was part of the initial plan.

\section{References}

Aukrust, V. G. (2005). Tidlig språkstimulering og livslang laering - en kunnskapsoversikt (Early language stimulation and lifelong learning - a knowledge overview). A report for the Ministry of Education and Research. Oslo, Norway.

Estil, L. B. (2002). Underlying deficits in motor and language impairments in children. Trondheim, Norway: Dr. polit. 2002, NTNU.

Gjems, L. and Løkken, G. (2011). Barns leering om språk og gjennom språk (Children learning about language and through language). Oslo, Norway: Cappelen Damm Akademisk.

Gubrium, J. F. and Holstein, J. A. (1997). The New Language and Qualitative Method. New York, USA: Oxford University Press.

Hammersley, M. and Atkinsen, P. (2004). Feltmetodikk (Field metodologi). Oslo, Norway: Gyldendal Akademisk forlag.

Hilmo, I., Holter, K. and Langholm, G. (2006). "Naturfagsnikksnakk" (Science chit chat). Oslo, Norway: Barnehagefolk (Preschool people) 4/2006.

Høigård, A. (2013). Barns språkutvikling muntlig og skriftlig (Children’s language development oral and written). Oslo, Norway: Universitetsforlaget.

Jagtøien, G. L. and Hansen, K. (2000). I bevegelse, sansemotorikk, leik, observasjon (In motion, sensory motor, play, observation). Oslo, Norway: Gyldendal Norsk forlag.

Law, J. (2007). After method, mess in social science research. Oxon, Great Britain: Routledge.

Løge, I. K. (2011). Språkvanskar og sosioemosjonelle vanskar (Language disorders and socio-emotional problems). In: Midthassel, Bru, Ertsvåg og Roland (red.): Sosiale og emosjonelle vansker: Barnehagens og skolens møte med sårbare barn og unge (Social and emotional problems: Preschools and schools meeting with vulnerable children and youths) (pp. 56-73). Oslo, Norway: Universitetsforlaget.

McNiff, J. (1995). Action Research for Professional Development. London, UK: Routledge.

Postholm, M. B. (red) (2006). Forsk med! Larere og forskere i laringsarbeid (Research! Teachers and researchers in learning). Oslo, Norway: N W Damm og søn. 
Sverdrup, S. (2002). Evaluering, faser, design og gjennomføring (Evaluation, phases, design and implementation). Bergen, Norway: Fagbokforlaget.

Tiller, T. (2006). Aksjonsforskning - forskende partnerskap i skolen (Action research researching partnership in the school). Kristiansand, Norway: Høyskoleforlaget.

Tusenbein (2009). Språkjungelen (Language Jungle). Appliance to Nordland Fylkeskommune (Nordland County Council). Norway.

Tusenbein Barnehage (2018). Tusenbein barnehage BA (Centipede Preschool). Mo i Rana: homepage. Retrieved from http://tusenbein.barnehage.no/Innhold/Side/93148 (28.04.18).

Vedeler, L. (2000). Observasjonsforskning i pedagogiske fag (Observation research in pedagogical subjects). Oslo, Norway: Gyldendal.

Vygotskij, L. (1978). Mind in Society: Development of Higher Psychological Processes. London, UK: Harvard University Press. 


\title{
ASSESSING THE OPINIONS OF PEDAGOGICAL SPECIALITIES STUDENTS ON THE USE OF DISTANCE LEARNING
}

\begin{abstract}
In recent years, distance learning has made considerable advances, with students working towards varied professions using this pedagogical method. The aim of this study was to assess the awareness and experiences of full-time and part-time pedagogical specialities students from the University of Latvia about distance learning. An electronic survey of these students, on their knowledge and opinions toward distance learning, was carried out. The results of the research show that pedagogical specialities students are poorly informed about possibilities of obtaining an education through distance learning. The majority of the surveyed students ( $78 \%$ of full-time students and $69 \%$ of part-time students) had no distance learning experience, with more part-time students having previous contact with distance learning methods than full-time students. Many surveyed students agree with the point of view that distance learning could be successfully used in secondary school and higher education level, with the majority of students believing that, in the future, distance learning will become a more dominant form of education. The majority of participants studying part-time (68\%) accept the use of distance learning in teacher training, but the majority of surveyed full-time students (56\%) do not accept the use of distance learning in teacher training.
\end{abstract}

Keywords: distance learning, pedagogical specialities, full-time students, part-time students, education levels, teacher training.

\section{Introduction}

In recent years, the use of information technologies, mobile devices, and social media in education has grown rapidly, meeting the evolving needs of students, professionals, and academics (Ordonez de Pablos, Tennyson, 2015). By using distance learning it is possible to link traditional lessons with new information and communication technologies in a flexible way. 
Distance learning is a form of education where students study and get an education at a distance from study site, if a computer with an internet connection is available. Distance learning is characterised by specially structured study materials and individual learning rates. A specifically organised assessment of educational achievements is used in it. Having a full-time job, accessibility and flexibility, individual responsibility, effective time management, physical distance, institutional prestige, and disability are the common factors influencing a preference amongst undergraduate and graduate learners for online learning (Hale, Yasemin, 2017). Distance learning systems, in the form of internet-supported platforms, offer numerous possibilities for creating different teaching and learning modes, based on the important pre-conditions of communication, interaction, and collaboration (Barjaktarović, Stanković, 2014).

Students generally hold a positive perception and attitude towards open and distance learning, compared to traditional forms of higher education (Ojo, Olakulehin, 2006). For example, findings have demonstrated that the reaction-based satisfaction level of Kuwait University students in online education is significantly high. About $95 \%$ of the participants, asserted that they are eager to take more training courses offered online (Safar, 2012). Research at Florida public university, which offers various degrees at undergraduate and graduate levels, suggests that those students who had never dropped an online course were influenced by instructional strategies and interaction and were satisfied with their online courses, thus remaining enrolled and engaged (Wise, 2012). The satisfaction level of students in Kocaeli University (Turkey) with regard to e-education courses is moderate; when the sub-dimensions were examined, satisfaction was high in terms of the instructor-student interaction and environment design sub-dimensions, while it was moderate in terms of the course content and teaching process, materials used, and communication tools. When interaction and communication tools, such as a virtual classroom, forum, chat, e-mail, web page, animation, video, graphics and images as content tools, and questionnaires as assessment tools, were used, satisfaction was higher in these courses (Topal, 2016). Analyses carried out indicate that the level of intrinsic motivation amongst open and distance education students is high in e-learning environments (Firat, Kilinc, 2018).

There are different advantages of distance learning in comparison with traditional study methods. Among them are the opportunity to create your own learning schedule, the ability to live and study away from an educator, and to combine studies with full-time work and other obligations. At the same time, the direct contact with educators is not so close, and it could lead to difficulties obtain complex professions. It is recommended that studies using distance learning involve additional learning time, 
instructional resources, and course elements that encourage interactions among learners (Means, Toyama, 2013).

The main risks of distance education are concentrated in two dimensions. The first is "basic or general" with high incidence of "fear of making mistakes" and "ignorance of the course content", while the second "own and beyond students' circumstances" where it is important to stand out the risks not directly controlled by the students: "warning from the authorities for not developing the program", "isolation from teachers" and "delegation of control" (Vazquez-Cano, Sevillano, 2015). The following elements are crucial in order for the distance learning environment to be effective: smooth communication between online students and the instructor, smooth communication between the online students and classroom students, the engagement of the online students and the redesign of certain instructional activities, balanced attention from the instructor to the students, and a high quality of audio (Wang, Huang, 2018).

In recent years, distance learning has advanced considerably. The expansion of distance learning and an understanding of its benefits has led to the growth of methodologies, pedagogies, and models aimed at diversifying and maximising the student experience and increasing student numbers (Gauld, Whatley, 2017).

The fields of distance and online education are experiencing continuing growth. Starting from simple forms of correspondence courses, this field has passed through various generations, employing various forms of simple and complex technology, like radios, televisions, computers, satellites, the internet, Wikis, and Web 2.0 applications (Demiray, Sever, 2009).

Massive Open Online Courses (MOOCs) are an innovative form of free distance learning which is represented by full-fledged interactive training courses, openly accessible on the internet for the simultaneous participation of a large number of people (Avshenyuk, 2016). MOOCs are serving non-consumers. Although they are limited in the services they provide compared with traditional colleges, they offer free and accessible education to a broader audience who cannot afford the traditional provision. However, this is a characteristic of online distance learning in its broadest sense. For MOOCs to be disruptive, they have to open up markets by competing with existing firms, using low-cost business models, improvements beyond the level of the original competitors, taking price differences into account, and replacing the established firms (Langen, van den Bosch, 2013). In 2012, DOCCs (Distributed Open Collaborative Courses) were developed, which allow the theme and course organisation to change based on the students' intervention. Similarly, SPOCs (Self-Paced Online Courses), enhance student flexibility in terms of the learning start and the rhythmicity of the study (Nuta, Pusca, 2017). There are different innovations in 
distance education, such as software applications, open source courseware, online learning platforms, and web 2.0 technologies. Coupled with this, there is increasing interest and debate around the possibilities that novel innovations can have on changing education practices and providing more effective learning solutions (Carrier, 2017).

Teacher education and open and distance learning are complex and critically important fields of endeavour. Used together, they have the potential to enhance the effective, efficient, and equitable provision of education, and to maximise access to such provision to various categories of disadvantaged learners (Umar, Danaher, 2010). Teacher training is increasingly emphasising social competencies and intercultural awareness. Online pedagogies based on sociocultural methods can support productive learning communities that span diverse cultural backgrounds. The cultural dimensions of learning frameworks could provide a useful stimulus to promote discussion amongst learners and teachers that could raise awareness of the cultural basis of a diversity of approaches to learning (Hunt, Tickner, 2015). With the rise of distance education, progressive research on the best methods, tools, and technologies in the field is necessary to continue to take advantage of the pedagogical opportunities and improvements offered through remote learning platforms (Yuzer, Gulsun, 2014).

Throughout the world, open and distance learning has been used for inservice teacher education over many years, in different education systems and in diverse social and cultural contexts (Harreveld, 2010). However, teacher training always sits within national and international policy frameworks and is subject to the vagaries often associated with the policy (Simpson, Kehrwald, 2010). Networked computing and communications technologies open up new delivery possibilities for both the distance and face-to-face delivery of teacher education. Blended (or hybrid) learning which combines not only modes of delivery but also approaches to teaching and learning has emerged as a powerful option for teacher education providers wishing to tailor their programmes to suit increasingly diverse and dispersed cohorts of learners (Simpson, Kehrwald, 2010).

The aim of this study was to assess the awareness and experiences of full-time and part-time pedagogical specialities students from the University of Latvia in distance learning and gauge their opinion about the use of distance learning in different levels of education.

\section{Methods and Materials}

An electronic survey of pedagogical specialities students from the University of Latvia was carried out, regarding their knowledge and opinions towards distance learning. The questionnaire consisted of eight 
questions. Four of these were connected with students' awareness and experiences in distance learning, one question was about students' opinions of the use of distance learning in different educational levels, two questions were connected with students' opinions of the necessity for more detailed information about distance learning for students and perspectives of distance learning in future, and one question dealt with students' opinions regarding the use of distance learning in teacher training. The answers of full-time students and part-time students were compared. The questionnaire gave an understanding of the awareness and experiences of students with regard to distance learning, their point of view about the use of distance learning in different levels of education and the use of distance learning in future, and students' opinions about the use of distance learning in teacher training. The link to the questionnaire was sent to different full-time and part-time student groups. 46 full-time students and 62 part-time students from the University of Latvia were surveyed. SPSS statistical data processing software was used for statistical analysis, with the Mann-Whitney U test used for data analysis.

\section{Results and Discussions}

The results of the research show that the majority of full-time pedagogical specialities students are informed (46\%) or partly informed (31\%) about the possibilities of obtaining an education by using distance learning, with the majority of part-time students being partly informed (67\%) about possibilities to get an education by using distance learning (see Figure 1). Only $23 \%$ of full-time students and $11 \%$ of part-time students answered that they were not informed regarding the possibilities of obtaining an education by using distance learning.

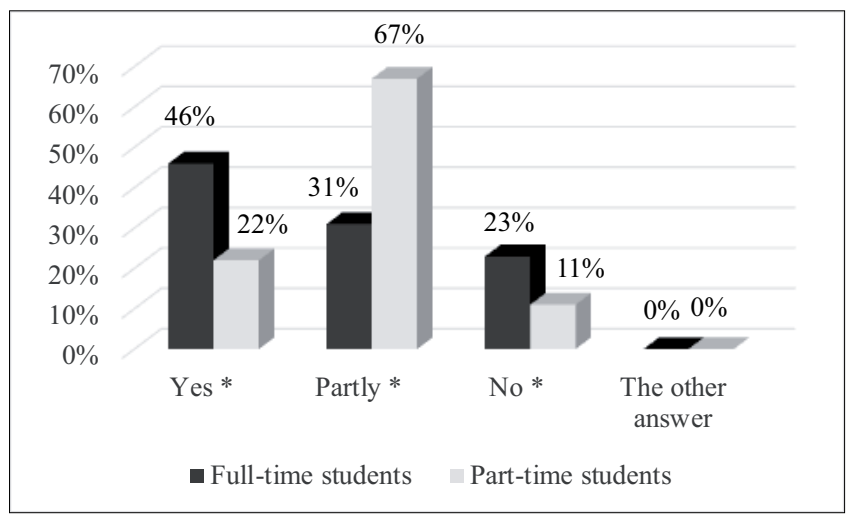

Figure 1. The opinions of students regarding their awareness about possibilities to obtain an education by using distance learning (in $\%$ of respondents in groups) ( $* p<0.05)$ 
The majority of students have no experience in the using of distance learning (see Figure 2).

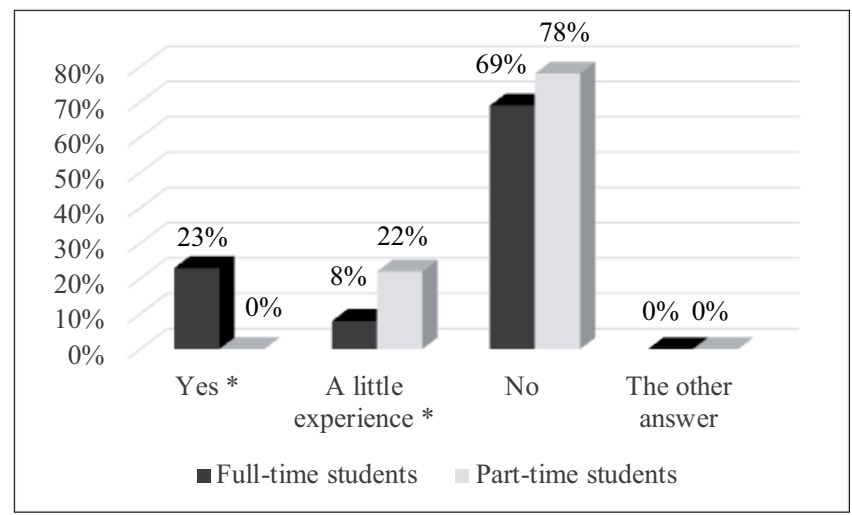

Figure 2. Students' experience of the use of distance learning (in $\%$ of respondents in groups) $(* p<0.05)$

$69 \%$ of full-time students and $78 \%$ of part-time students admit that they have not had such experience. Only $23 \%$ of full-time students have experience in distance learning. $22 \%$ of part-time students and $8 \%$ of fulltime students have a little experience in distance learning.

The majority of surveyed students had not used distance learning at school (see Figure 3). 78\% of full-time students and $61 \%$ of part-time students had not used distance learning at school, with $31 \%$ of surveyed part-time students and $22 \%$ of full-time students having had partly experiences with distance learning at school. Only $8 \%$ of part-time students had used distance learning at school.

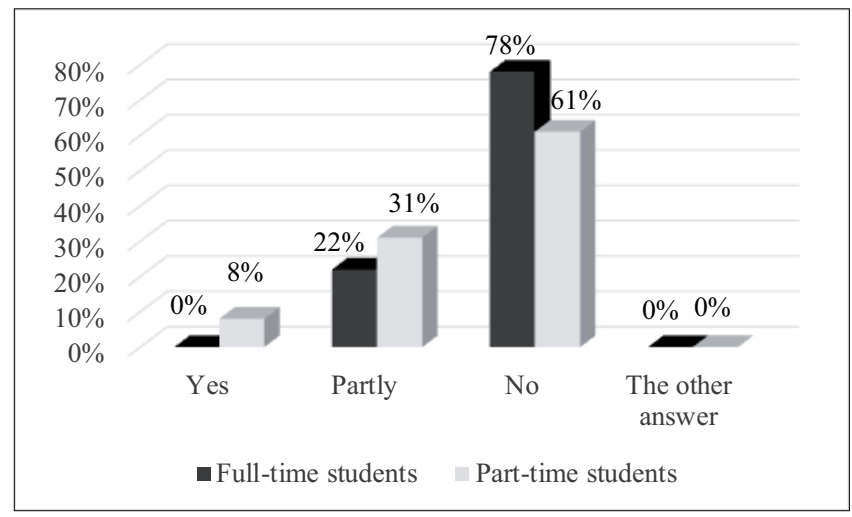

Figure 3. Students' views on their using of distance learning at school (in $\%$ of respondents in groups) 
The majority of surveyed students had not used distance learning at the university either (see Figure 4). $78 \%$ of full-time students and $46 \%$ of part-time students had not used distance learning at university. At the same time, $46 \%$ of part-time students had partly used, and $8 \%$ of parttime students had used, distance learning at university. Therefore, parttime students have more experience of distance learning at university in comparison with full-time students.

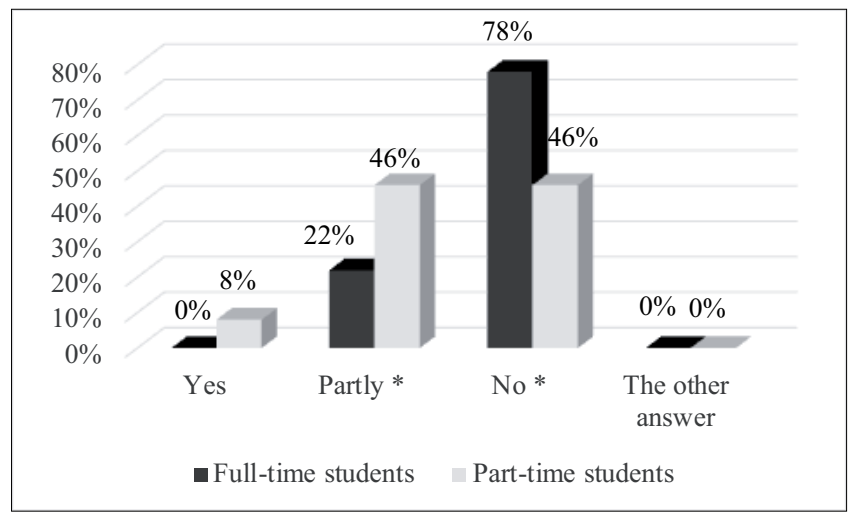

Figure 4. Students' views on their using of distance learning at university (in $\%$ of respondents in groups) ( $* p<0.05$ )

The majority of students agree with the opinion that distance learning could be used in higher education levels (see Table 1). $78 \%$ of surveyed full-time students do not support distance learning at the primary school level, and $67 \%$ of them do not support distance learning at the basic school level. Part-time students are less categorical, but the majority do not accept distance learning in primary (62\%) and basic school level (46\%) either. At the same time, $44 \%$ of full-time students accept, and $56 \%$ of them accept in some cases, distance learning at the secondary school level, with 78\% of full-time students accepting, and $22 \%$ of them accepting in some cases, distance learning in higher education level. 53\% of part-time students accept distance learning at the secondary school level and $77 \%$ of part-time students accept distance learning at the level of higher education.

The majority of part-time students (54\%) agree with the opinion that it is necessary to give students more detailed information about distance learning and its advantages (see Figure 5). It appears that full-time students are less interested in distance learning. 45\% of full-time students do not agree with the statement that it is necessary to give students more detailed information about distance learning and its advantages but 33\% of them rather agree to this statement. There are no students who strongly disagree with this statement. 
Table 1. The opinion of students regarding the use of distance learning at different education levels (in \% of respondents in groups)

\begin{tabular}{|c|c|c|c|c|c|c|c|c|}
\hline \multirow{2}{*}{$\begin{array}{c}\text { Levels of } \\
\text { education }\end{array}$} & \multicolumn{7}{|c|}{ The opinion of students } \\
\cline { 2 - 9 } & Accept & $\begin{array}{c}\text { Accept } \\
\text { in some } \\
\text { cases }\end{array}$ & $\begin{array}{c}\text { Do not } \\
\text { accept }\end{array}$ & $\begin{array}{c}\text { I have } \\
\text { no } \\
\text { opinion }\end{array}$ & Accept & $\begin{array}{c}\text { Accept } \\
\text { in some } \\
\text { cases }\end{array}$ & $\begin{array}{c}\text { Do not } \\
\text { accept }\end{array}$ & $\begin{array}{c}\text { I have } \\
\text { no } \\
\text { opinion }\end{array}$ \\
\hline $\begin{array}{c}\text { Primary } \\
\text { school level }\end{array}$ & 11 & 11 & 78 & 0 & 15 & 23 & 62 & 0 \\
\hline $\begin{array}{c}\text { Basic school } \\
\text { level }\end{array}$ & 11 & 22 & 67 & 0 & 23 & 31 & 46 & 0 \\
\hline $\begin{array}{c}\text { Secondary } \\
\text { school level }\end{array}$ & 44 & 56 & 0 & 0 & 53 & 47 & 0 & 0 \\
\hline $\begin{array}{c}\text { Higher edu- } \\
\text { cation level }\end{array}$ & 78 & 22 & 0 & 0 & 77 & 23 & 0 & 0 \\
\hline
\end{tabular}

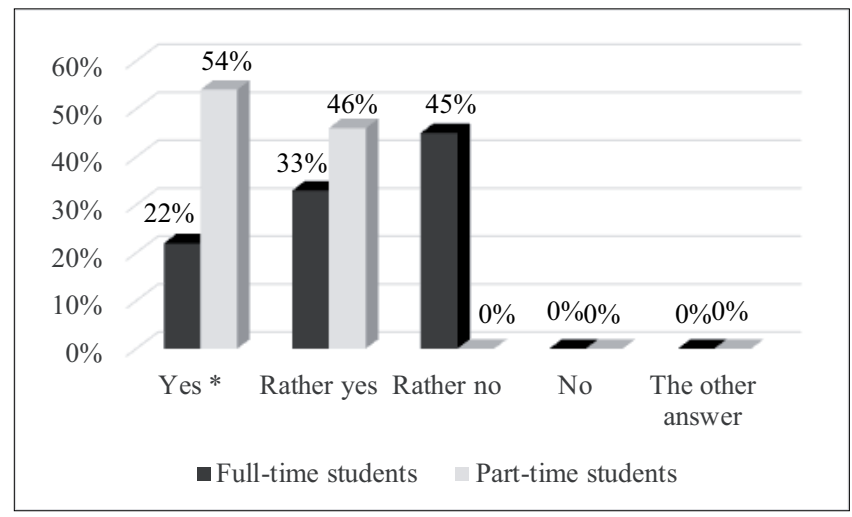

Figure 5. Students' opinions about whether it is necessary to give students more detailed information about distance learning and its advantages (in $\%$ of respondents in groups) ( $\left.{ }^{*} p<0.05\right)$

The majority of full-time (84\%), as well as part-time students 67\%), partly agree to the statement that distance learning will become the dominant form of education in the future (see Figure 6). More part-time students $(22 \%)$ in comparison with full-time students (8\%) strongly agree with this statement. 


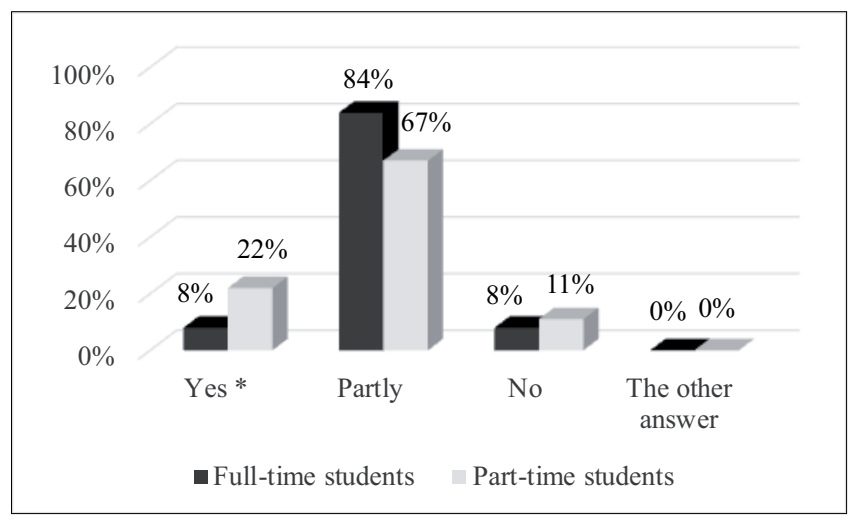

Figure 6. Students' opinions regarding distance learning becoming the dominant form of education in the future (in $\%$ of respondents in groups) (* $p<0.05$ )

Students have different opinions about the use of distance learning in teacher training (see Figure 7). 33\% of surveyed full-time students accept, and $11 \%$ of them rather accept, the use of distance learning in the teacher training. $33 \%$ of full-time students rather not accept the use of distance learning in teacher training, with $23 \%$ not accepting it. $22 \%$ of parttime students accept, and $46 \%$ of them rather accept, the use of distance learning in teacher training. However, $23 \%$ of part-time students rather not accept, and $8 \%$ of them do not accept, such use. The majority of surveyed pedagogical specialities students see the advantages of distance learning, but they suggest that it is necessary to have close contact with lecturers and teachers to take their experience and become a good teacher.

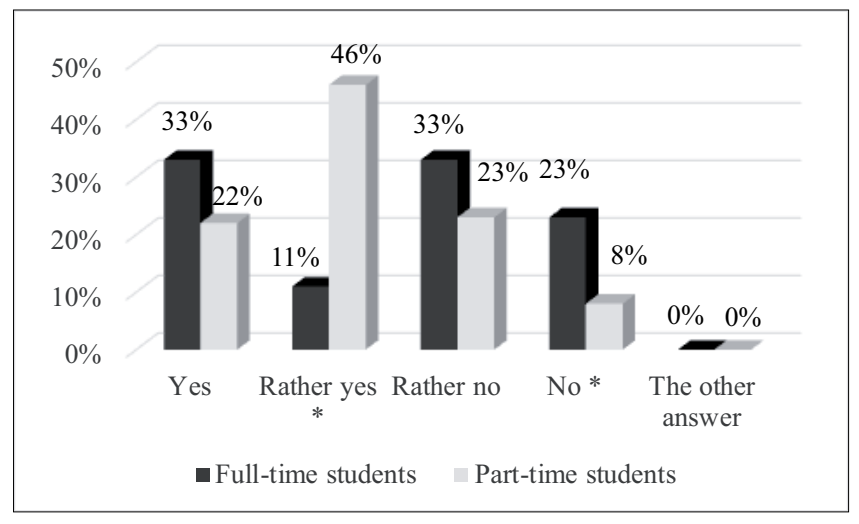

Figure 7. Students' opinions about the use of distance learning in teacher training (in $\%$ of respondents in groups) $(* p<0.05)$ 


\section{Conclusions}

1. Pedagogical specialities students from the University of Latvia are rather poorly informed about possibilities of obtaining an education using distance learning. The majority of surveyed students ( $78 \%$ of parttime students and $69 \%$ of full-time students) have no distance learning experience. Only $23 \%$ of full-time students have experience in distance learning.

2. More part-time students previously had contact with distance learning methods, when compared with full-time students in school and university. $31 \%$ of surveyed part-time students and $22 \%$ of full-time students having had partly experience with distance learning at school but $46 \%$ part-time students and $22 \%$ of full-time students having had partly experiences with distance learning at university.

3. The majority of pedagogical specialities students from the University of Latvia do not agree with the use of distance learning in primary school and basic school but agree or partly agree with the use of distance learning at the level of secondary school education or higher education. In comparison with full-time students, more part-time students admitted to the use of distance learning at the primary or basic school level. $23 \%$ of part-time students accept using of distance learning at the basic school level but only $11 \%$ of full-time students accept using of distance learning at this level.

4. All the surveyed pedagogical specialities part-time students, and $55 \%$ of the surveyed full-time students, consider that it is necessary to give students more detailed information about distance learning and its advantages. Part-time students are more interested in the distribution of information about distance learning in comparison with full-time students.

5. The majority of surveyed pedagogical specialities students ( $92 \%$ of fulltime students and $89 \%$ of part-time students) consider that distance learning will become, or partly become, the dominant form of education in future.

6. Students have different opinions about the use of distance learning in teacher training. The majority of surveyed part-time students (68\%) accept or rather accept the use of distance learning in teacher training. However, the majority of surveyed full-time students (56\%) do not accept, or rather do not accept, the use of distance learning in the teacher training. Only $22 \%$ of full-time students fully accept distance learning in the teacher training. At the same time $33 \%$ of part-time students fully accept distance learning in the teacher training. 


\section{References}

Avshenyuk, N. (2016). Priority Fields of Teachers' Professional Development in Terms of Open Education Worldwide. Comparative Professional Pedagogy, 6(4), 15-19.

Barjaktarović, L., Stanković, J., \& Gavrilović, J. (2014). The Role of Internet Technologies in Lecturing and Learning. Singidunum Journal of Applied Sciences. Supplement, 397-401.

Carrier, N. (2017). How educational ideas catch on: the promotion of popular education innovations and the role of evidence. Educational Research, 59(2), 228-240.

Demiray, U., \& Sever, N. S. (2009). Marketing Strategies in Open Distance Learning and Online Education. In: Demiray, U., Sever, N. S. (Eds.) The Challenges for Marketing Distance Education in Online Environment: An Intergrated Approach (pp. 3-68). Anadolu University: Eskisehir-Turkey.

Firat, M., Kilinc, H., \& Yuzer, T. V. (2018). Level of Intrinsic Motivation of Distance Education Students in e-learning Environments. Journal of Computer Assisted Learning, 34(1), 63-70.

Gauld, C., \& Whatley, P. (2017). Distance Learning for Information Professionals: A Practical, Reality-driven Model for Postgraduate Education. Education for Information, 33, 121-133.

Hale, I., \& Yasemin, G. (2017). Why Do Learners Choose Online Learning: The Learners' Voices. International Conference on E-Learning. Lisbon, Portugal, Jul 20-22, 2017. ISBN: 978-989-8533-63-0. Retrieved from: https://eric.ed.gov/contentdelivery/servlet/ ERICServlet $?$ accno $=$ ED579379.

Harreveld, R. E. (2010). A Capability Approach to Open and Distance Learning for In-Service Teacher Education. In: Danaher, P. A. \& Umar, A. (Eds.) Teacher Education through Open and Distance Learning (pp. 47-60). Vancouver: Commonwealth of Learning.

Hunt, A., \& Tickner, S. (2015). Cultural Dimensions of Learning in Online Teacher Education Courses. Journal of Open, Flexible and Distance Learning, 19(2), 25-47.

Langen, H. \& van den Bosch, H. (2013). Massive Open Online Courses: disruptive innovations or disturbing inventions? Open Learning, 28(3), 216-226.

Means, B., Toyama, Y., Murphy, R. F., \& Baki, M. (2013). The Effectiveness of Online and Blended Learning: A Meta-Analysis of the Empirical Literature. Teachers College Record, 115(3), 1-47.

Nuta, A. C., \& Pusca, A. C. (2017). An Assessment of Distance Learning Education Platform Options and Opportunity. Journal of Public Administration, Finance \& Law, 11, 113-120.

Ojo, D. O., \& Olakulehin, F. K. (2006). Attitudes and Perceptions of Students to Open and Distance Learning in Nigeria. International Review of Research in Open and Distance Learning, 7(1), 1-10.

Ordonez de Pablos, P., Tennyson, R. D., \& Lytras, M. D. (2015). Assessing the Role of Mobile Technologies and Distance Learning in Higher Education. Hershey, PA: IGI Global.

Safar, A. H. (2012). The Students' Perspectives of Online Training at Kuwait University. College Student Journal, 46(2), 436-458.

Simpson, M., \& Kehrwald, B. (2010). Educational Principles and Policies Framing Teacher Education through Open and Distance Learning. In: Danaher, P. A. \& Umar, A. (Eds.) Teacher Education through Open and Distance Learning (pp. 23-34). Vancouver: Commonwealth of Learning. 
Topal, A. D. (2016). Examination of University Students' Level of Satisfaction and Readiness for E-Courses and the Relationship between Them. European Journal of Contemporary Education, 15(1), 7-23.

Umar, A., \& Danaher, P. A. (2010). Setting the Scene for Interrogating Teacher Education through Open and Distance Learning. In: Danaher, P. A. \& Umar, A. (Eds.) Teacher Education through Open and Distance Learning (pp. 1-6). Vancouver: Commonwealth of Learning.

Vazquez-Cano, E., Sevillano, G., \& Ma, L. (2015). Analysis of Risks in a Learning Management System: A Case Study in the Spanish National University of Distance Education (UNED). Journal of New Approaches in Educational Research, 4(1), 62-68.

Wang, Q. Y., Huang, C. Q., \& Quek, C. L. (2018). Students' Perspectives on the Design and Implementation of a Blended Synchronous Learning Environment. Australasian Journal of Educational Technology, 34(1), 1-13.

Wise, T. L. (2012). The Influence of Interactivity and Instructional Strategies on Retention and Satisfaction in Distance Learning Environments. (Doctoral dissertation). The University of West Florida, 85 pp. Available: ProQuest LLC. 789 East Eisenhower Parkway, P. O. Box 1346, Ann Arbor, MI 48106. Tel: 800-521-0600. Retrieved from http://datubazes. lanet.lv:2236/en-US/products/dissertations/individuals.shtml.

Yuzer, V. T., \& Gulsun, E. (2014). Handbook of Research on Emerging Priorities and Trends in Distance Education: Communication, Pedagogy, and Technology. Hershey, PA: IGI Global. 


\title{
ASSESSMENT IN MARITIME EDUCATION BY STUDENTS' MUTUAL COLLABORATION
}

\begin{abstract}
Student's self-assessment must be taken into account as well as teacher's assessment to evaluate educational process and the level gained. Students in Latvian Maritime Academy get a unique sea going experience that can be shared. Students in self-assessment charts marked course mate made assessment about their competencies. They assess each other rather seldom. As self-assessment in educational psychology is explained as parameter that arises also in relationship with others, it is important to organize involvement of fellow students in assessing process. Results of questionnaire about mutual assessment made by students about other students showed that such assessing method can be reliable if such opportunity is offered and criteria are known. Important abilities to assess in other students' activities include choosing an objective, ability to enrich self-experience. In this process collaboration is improved and mutual trust can be raised.
\end{abstract}

Keywords: awareness, collaboration, evaluation, self-assessment.

\section{Introduction}

Insufficient student's self-assessment leads to increasing pedagogue evaluation into educational process by using assessment done by pedagogue. Such criteria as the only one does not fully describe the quality of educational process and the level of qualification gained. There is a specification of minimum standard of competences for officers in charge of navigational watch, chief mates and masters on ships to prove ability of safe operation and management of vessels. Such standards are stipulated in the International Convention on Standards of Training, Certification and Watchkeeping for Seafarers and included in professional maritime education subjects (International Maritime Organization, 2011). 
Self-assessment derives from valuation made by student own and valuation made by others around. L.S.Vygotsky's sociocultural theory of human learning describes learning as a social process, in which author believes that before learning individually, everything is learned through interaction with others (Vygotsky, 1978). This theory is further investigated by several researchers. That is essential to organize such interaction to make self-assessment as a component of study process (Maslo, 2006, Meikšāne, Plostnieks, 1998).

Studies in Latvian Maritime Academy (LMA) are alternated with sea going practice at least twice to get a ship officer's qualification. A board of the ship is made as study environment as well as academy. In this way students get unique self-experience that can be shared among fellow students. After completing Watchkeeping studies every half year in LMA students filled self-assessment charts to determine their level of understanding ship collision avoidance rules and watchkeeping principles. Beside students marked source from which such understanding is determined. Whether it is self-assessment, teacher's evaluation or assessment is made by course mate. Unfortunately, students assess each other rather seldom and reasons for that must be found. In the second step a questionnaire about mutual collaboration between students in assessing each other were given to make conclusions about study process and possibility to improve that.

\section{Self-assessment in studies}

Five questions of quest do exist. Three of them about facts - what, where, when? Two of those questions are about cause and motivation of activity why and wherefore? That makes students think about personal and social objectives in activity. An interaction in society leads to sense of study and answers what to do, if question about causes had been highlighted. None of the cause exists without consequences, so cause and consequences are sides of causation. Defining the cause means to explain, but not contrariwise (Vedins, 2008). A switch from changing person to offering a relationship which this person may use for his own personal growth makes that the change and personal development will occur (Rogers, 1993).

The teacher can offer system how to develop needed competencies by organizing work in groups, discussions, different tasks. Competence can be explained as proved ability to use knowledge and skills for personal and social growth in methodical and educational situations, also professional cases. Competence in relevance with personal responsibility and autonomy create dynamic combination of cognitive and metacognitive skills, ability to use and understand gained knowledge as well as interpersonal, intellectual, practical and ethical skills (Taurina, 2013). Competence is described as 
quality level of human activity that divulges in exact situation. It is found in observing and self-evaluating (Tillla, 2005).

Collaboration between students and teacher as well as among students themselves creates transfer of competence by self-experience. That is useful in professional subjects in LMA. A perfection of self-experience is professional growth. Skills that are gained in one particular subject can be used in other subjects and for solving problematic cases. So the transfer of theoretical competence from learning to practice happens. Ability to use conclusions is being developed. Evaluating of self-experience is complex and difficult to realize because it evolves personal for each student individually.

Self-assessment in educational psychology is explained as a cognitive parameter that grows out of self and other valuation. It starts to develop in childhood and firstly comes from comparison of surrounding people. Self-assessment arises and discloses not only in activity, but in relationship with others as well (Šteinberga, 2013). Furthermore McKay and Fanning (2000) point out that ability to define identity and give a value to that, so as awareness about himself, are critical factors for human being. They express that self-awareness comes together with self-esteem. It is crucial to open up for others, to hear critics, ask for help or additional explanation or problem solving. Authors link that with being afraid among course mates. Significance of freedom expands as perception and sense of judgments changes.

\section{Methodology}

In LMA self-assessment charts where given for the third and fourth year students of Navigation Department to mark the level of knowledge after completing studies in Watchkeeping. The fourth year students filled selfassessment charts in year 2016 and 2017 (respectively 49 and 36 students), but the third year students in year 2017 only (36 students) to show whether they mastered totally, partly or did not learn or gained abilities at all.

Parameters they marked were defined as competencies concerning the International Rules for Avoiding Collisions at Sea and watchkeeping principles stipulated in the International Convention on Standards of Training, Certification and Watchkeeping for Seafarers. That includes competence as skills proving knowledge and ability to provide safe navigation watch on the ship's bridge to avoid collisions and steer the ship safely.

Assistance for maritime education and training institutions and their teaching staff can be found in International Maritime Organization model courses. Precisely for officers in charge of navigational watch, chief mates and masters on ships model courses 7.03 Officer in Charge of a Navigational Watch and 7.01 Master and Chief Mates are made to introduce and organize 
new training courses and enhance existing training material. In such manner the quality and effectiveness of education process may be improved. The model course material identifies the basic entry requirements and specifies the technical content and levels of knowledge and skills necessary to fulfill related recommendations and conventions (International Maritime Organization, 2014).

Additional students marked the source from which they know their level of particular knowledge and ability. Whether they think of knowing parameters as teacher said that they know, or course mates said that, or students is aware of knowing parameters by their self-assessment.

Low percentage of course mate evaluation being used in studies led to the next step of research. Causes and solutions are searched for such unpopular method for assessing knowledge and abilities that makes up competence as using course mate's account of level being reached. Creating a questionnaire about using assessment made by the course mates was on purpose to find why students do not use such method so often. Additionally students answered questions under what conditions the assessment made by course mate can be used as a reliable method and if there are professional study subjects where students had been given an opportunity to evaluate each other. Importance factors what abilities must be considered during assessing others among course mates were asked.

The questionnaire covered 11 students of the fourth year and 30 students of the third year. Little number of the fourth year students is due to being at sea going practice on ships during the time when the survey was carried out. Methodology of that questionnaire can be further provided for all students just to obtain data in several subjects and program of studies overall.

\section{Results}

In year 2016 the fourth year students marked self-assessment as the source of their awareness in about $50.63 \%$ of all skills required (average 26.33 out of 52 ), but in $36.19 \%$ of all skills students marked that teacher made evaluation (average 18.82 out of 52). Among the fourth year students in year 2017 these variables had been changed to $39.69 \%$ (20.64 out of 52 skills) of self-assessment and $32.85 \%$ ( 17.08 out of 52 skills) of teachers made. In year 2017 the third year students marked $40.60 \%$ (19.08 out of 47) as self-assessment and $44.62 \%$ (20.97 out of 47) as teacher evaluation of the level they reached in Watchkeeping skills (there are less skills being evaluated in the third grade). Surprisingly that course mate evaluation is not considered, showing only $0.89 \%$ ( 0.42 out of 47 skills in the third grade) to $3.10 \%$ (1.61 out of 52 skills in the fourth grade), in determining students' level of competence (see Tables 1 \& 2). 
Table 1. Source of the knowledge level ( $4^{\text {th }}$ grade)

\begin{tabular}{ccccc}
\hline \multirow{2}{*}{$\begin{array}{c}\text { Assessment } \\
\text { comes from }\end{array}$} & \multicolumn{3}{c}{ skills marked by $4^{\text {th }}$ grade students } \\
\cline { 2 - 5 } & \multicolumn{3}{c}{2016} & \multicolumn{2}{c}{2017} \\
\cline { 2 - 5 } & count & percentage \% & count & percentage \% \\
\hline teacher & 18.82 & $36.19 \%$ & 17.08 & $32.85 \%$ \\
course mate & $\mathbf{0 . 7 8}$ & $\mathbf{1 . 4 9 \%}$ & $\mathbf{1 . 6 1}$ & $\mathbf{3 . 1 0 \%}$ \\
self-assessment & 26.33 & $50.63 \%$ & 20.64 & $39.69 \%$ \\
teacher \& self-assessment & 2.55 & $4.91 \%$ & 4.75 & $9.13 \%$ \\
teacher \& course mate & $\mathbf{0 . 0 0}$ & $\mathbf{0 . 0 0 \%}$ & $\mathbf{0 . 0 3}$ & $\mathbf{0 . 0 5 \%}$ \\
course mate \& self- & $\mathbf{0 . 0 4}$ & $\mathbf{0 . 0 8} \%$ & $\mathbf{0 . 0 0}$ & $\mathbf{0 . 0 0 \%}$ \\
assessment & & & & \\
without answer & 3.43 & $6.59 \%$ & 7.81 & $15.01 \%$ \\
teacher \& course mate \& & $\mathbf{0 . 0 6}$ & $\mathbf{0 . 1 2} \%$ & $\mathbf{0 . 0 8}$ & $\mathbf{0 . 1 6 \%}$ \\
self-assessment & & & & $100.00 \%$ \\
\hline Total & 52.00 & $100.00 \%$ & 52.00 &
\end{tabular}

Results of questionnaire showed that opportunity to evaluate course mates they had in such subjects as Environment Protection, Ship Handling and Maneuvering, Navigation, Meteorology for Navigation and others. On question "Do you think that assessment made by course mate can be considered as reliable?" most of students answered affirmative (see Table 3).

Table 2. Source of the knowledge level ( $3^{\text {rd }}$ grade and summing)

\begin{tabular}{|c|c|c|c|c|c|}
\hline \multirow[t]{3}{*}{$\begin{array}{l}\text { Assessment } \\
\text { comes from }\end{array}$} & \multirow{2}{*}{\multicolumn{2}{|c|}{$\begin{array}{c}\text { skills marked by } \\
3^{\text {rd }} \text { grade students } \\
2017\end{array}$}} & \multirow{3}{*}{$\begin{array}{c}\text { Average } \\
2017 \\
\text { (3 }^{\text {rd }} \& \\
4^{\text {th }} \text { grade) }\end{array}$} & \multicolumn{2}{|c|}{ Difference of } \\
\hline & & & & \multirow[b]{2}{*}{$4^{\text {th }}$ grade } & \multirow[b]{2}{*}{ years } \\
\hline & count & $\begin{array}{c}\text { percentage } \\
\%\end{array}$ & & & \\
\hline teacher & 20.97 & $44.62 \%$ & $38.74 \%$ & $-3.33 \%$ & $2.55 \%$ \\
\hline course mate & 0.42 & $0.89 \%$ & $1.99 \%$ & $1.61 \%$ & $0.50 \%$ \\
\hline self-assessment & 19.08 & $40.60 \%$ & $40.15 \%$ & $-10.94 \%$ & $-10.48 \%$ \\
\hline teacher \& self-assessment & 2.39 & $5.08 \%$ & $7.11 \%$ & $4.23 \%$ & $2.20 \%$ \\
\hline teacher \& course mate & 0.00 & $0.00 \%$ & $0.03 \%$ & $0.05 \%$ & $0.03 \%$ \\
\hline course mate $\&$ self-assessment & 0.11 & $0.24 \%$ & $0.12 \%$ & $-0.08 \%$ & $0.04 \%$ \\
\hline without answer & 4.03 & $8.57 \%$ & $11.79 \%$ & $8.42 \%$ & $5.20 \%$ \\
\hline $\begin{array}{c}\text { teacher \& course mate \& } \\
\text { self-assessment }\end{array}$ & 0.00 & $0.00 \%$ & $0.08 \%$ & $0.04 \%$ & $-0.04 \%$ \\
\hline Total & 47.00 & $100.00 \%$ & $100.00 \%$ & & \\
\hline
\end{tabular}


Table 3. Reliability of assessment made by course mate

\begin{tabular}{ccccc}
\hline \multirow{2}{*}{$\begin{array}{c}\text { Do You think that assessment made } \\
\text { by course mate can be considered as } \\
\text { reliable? }\end{array}$} & \multicolumn{2}{c}{$3^{\text {rd }}$ year students } & \multicolumn{2}{c}{$4^{\text {th }}$ year students } \\
\cline { 2 - 5 } & count & $\begin{array}{c}\text { percentage } \\
\%\end{array}$ & count & $\begin{array}{c}\text { percentage } \\
\%\end{array}$ \\
\hline Yes & 17 & 56.7 & 7 & 63.6 \\
No & 13 & 43.3 & 4 & 36.4 \\
\hline Total & 30 & 100.0 & 11 & 100.0 \\
\hline
\end{tabular}

Results showed that ability to choose an objective (a goal), ability to enrich self-experience with new knowledge, skills and attitudes were first two abilities for the fourth year students as well as for the third year students. Ability to take responsibility for learning outcomes was ranked as the third. Position in the rank is made by summing every answer's points (1 - the most important, 5 - the least important) (see Table 4).

Table 4. Important abilities to consider during assessing course mates

\begin{tabular}{ccc}
\hline What is the most and the least important abilities to & $\begin{array}{c}3^{\text {rd }} \text { year } \\
\text { assess course mates? }\end{array}$ & $\begin{array}{c}4^{\text {th }} \text { year } \\
\text { students }\end{array}$ \\
\cline { 2 - 3 } (1 - the most important, 5 - the least important) & Points & Points \\
\hline Ability to choose an objective (a goal) & 69 & 23 \\
Ability to enrich self-experience with new knowledge, \\
$\begin{array}{c}\text { skills and attitudes } \\
\text { Ability to take responsibility for learning outcomes }\end{array}$ & 74 & 23 \\
Ability to choose means for reaching an objective & 84 & 24 \\
Ability to assess collaboration "student-student-teacher" & 126 & 34 \\
\hline
\end{tabular}

Answers on question "For what reasons in Your opinion it is so low proportion of and insignificant changes in course mate made assessment (see Table 1)?" showed that mainly such situation is due to little emphasis of such option, fears that it will make negative impact on self-esteem and there are not known criteria for assessing (see Table 5). Other answers that were given in open form included several opinions. For example, course mate can give positive assessment that does not show his knowledge; attitude about evaluating is differing from ones resentment to not worrying about that; unwillingness to assess course mates low; self-assessment is the most precise because student better know his benefits from process of study. 
Table 5. Reasons for low proportion and insignificant changes in course mate made assessment

\begin{tabular}{|c|c|c|c|c|}
\hline \multirow{2}{*}{$\begin{array}{l}\text { For what reasons in Your opinion it is } \\
\text { so low proportion of and insignificant } \\
\text { changes in course mate made } \\
\text { assessment (see Table 1)? } \\
\text { (more than one answer possible) }\end{array}$} & \multicolumn{2}{|c|}{$3^{\text {rd }}$ year students } & \multicolumn{2}{|c|}{$4^{\text {th }}$ year students } \\
\hline & count & $\begin{array}{l}\text { percentage } \\
\quad \%\end{array}$ & count & $\begin{array}{l}\text { percentage } \\
\quad \%\end{array}$ \\
\hline Such option is not emphasized & 17 & 30.9 & 5 & 35.7 \\
\hline Criteria for assessing is not known & 10 & 18.2 & 5 & 35.7 \\
\hline $\begin{array}{l}\text { Impact on overall result of studies is } \\
\text { not known }\end{array}$ & 8 & 14.5 & 1 & 7.1 \\
\hline $\begin{array}{l}\text { Fears that it will make negative impact } \\
\text { on self-esteem }\end{array}$ & 14 & 25.5 & 3 & 21.4 \\
\hline Other & 6 & 10.9 & 0 & 0 \\
\hline Total & 55 & 100.0 & 14 & 100.0 \\
\hline
\end{tabular}

Self-awareness can be raised if course mate made assessment and selfassessment is coming closes each to other. That would lead for social unity in vocational studies. Answers of students showed that they can think about others as well as about themselves if such opportunity is created and exact parameters are known for evaluation.

\section{Conclusions}

Theoretical analysis and questionnaire that had been done gives reasonable chance to improve the quality of studies in Watchkeeping. By organizing collaboration among students mutual trust can be raised under known conditions. International Maritime Organization gives solutions for technical skills and abilities that must be accomplished to prove the level of competence. By including such parameters in self-assessment charts pedagogical objectives are reached. Self-awareness and self-esteem are raised as students become more responsible, more involved in the process of studies. Low percentage of course mate made assessment in the educational process can be improved by giving opportunity to evaluate each other. It is showed that assessment from course mates is recognized as reliable if criteria for assessing are known. 


\section{References}

International Maritime Organization (2011). International Convention on Standards of Training, Certification and Watchkeeping for Seafarers. $3^{\text {rd }}$ consolidated edition. IMO Publication.

International Maritime Organization (2014). Master and Chief Mate. Model Course 7.01. UK, IMO Publication.

International Maritime Organization (2014). Officer in charge of a navigational watch. Model Course 7.03. UK, IMO Publication.

Maslo, I. (2006). No zināšanām uz kompetentu darbību (From knowledge to competent activities). Rīga: LU, 186 lpp.

McKay, M., Fanning, P. (2000). Self esteem, a proven program of cognitive techniques for assessing, improving, and maintaining your self-esteem. $3^{\text {rd }}$ ed. New York: Barnes\&Noble books, $316 \mathrm{p}$.

Meišāne, Dz., Plostnieks, I. (1998). Personības pašizjūta un identitāte (Self-knowledge and identity of personality). Rīga: Māc. apg. NC, 203 lpp.

Rogers, C. R. (1993). A therapist's view of psychotherapy - On becoming a Person. London: Constable, $420 \mathrm{p}$.

Šteinberga, A. (2013). Pedagoğiskā psiholoğija (Educational Psychology). Rīga: Raka, 176 lpp.

Tauriņa, Ž. (2013). Skolēna kompetenču pašvērtējums (Self-assessment of pupil's competencies). Rīga: Raka, 171 lpp.

Tillıa, I. (2005). Sociālkultūras mācīšanās organizācijas sistēma (Organization System of Sociocultural Learning). Rīga: Raka, 295 lpp.

Vedins, I. (2008). Zinātne un patiesība (Science and truth). Rīga: Avots, 702 lpp.

Vygotsky, L. S. (1978). Mind in society. Cambridge. MA: Harvard University Press. 133 p. 
Māra Urdziṇa-Deruma, Mārīte Kokina-Lilo, Gunta Treimane, Lolita Šelvaha

University of Latvia, Latvia

\title{
LATVIAN PUBLIC OPINION ON THE QUALITY OF HOME ECONOMICS AND TECHNOLOGIES
}

\begin{abstract}
At the moment in Latvia, general education reform is being implemented, introducing a competence-based learning approach and content. While implementing education reform, it is vital to learn public opinion. The goal of this study is to explore Latvian public opinion on the acquisition of materials processing technologies in comprehensive schools by finding out what Latvian society understands through a qualitative process of materials processing technologies' acquisition. In the study a questionnaire methodology has been used. The results are analysed from a qualitative and quantitative point of view. The obtained results show that Latvian society considers educators' competence and the materials supplies of workshops to be the most essential aspects for ensuring a quality Home Economics and Technologies subject. The respondents think that the domestic and practical skills and competencies are the key input in pupils' education. When expressing an opinion on the necessary changes, the largest percentage of respondents wanted to improve the content of learning and to include more practical tasks. Respondents' opinions are divided on the question as to whether all topics that have traditionally been optional should be mastered by all pupils equally. Respondents pay little attention to the aesthetic and cultural aspect, as well as the skills of creating craft design and artistic expression.
\end{abstract}

Keywords: home economics and technologies subject, quality of craft education, content of learning, craft skills.

\section{Introduction}

In Latvia, the subject Home Economics and Technologies has undergone changes both in name and goals, as well as a different subject curriculum. In each period of history, there have been different focuses on the subject's goals and curriculum. Already during the first Free State of Latvia 
(1918-1940) specialists of Home Economics and manual training saw the diverse importance of handiwork in personal development: physical development; preparation for practical life; linking theoretical knowledge to practice; development of creative capacities; and teaching taste of art (Urdziņa-Deruma, Mīlgrāve, 2014, p. 118). In the Soviet period (19401990) the major focus was on poly-technical education and production training (Žukovs, 1987). Since the occupation of Latvia and annexation by the USSR until the present, the curriculum of home economics has been embracing acquisition of various manual training techniques within one subject. In the current valid Home Economy and Technologies Standard (Noteikumi par valsts pamatizglītības standartu, pamatizglītības mācību priekšmetu standartiem un pamatizglìtības programmu paraugiem, 2014) both pupils' practical creative activities ranging from an idea to a creative product (including evaluation of the activity and work process) as well as promotion of cooperative skills have been emphasised. Regarding content, the subject is very similar to Estonia's model, where one subject contains both Home Economics and Craft (National curriculum for basic schools, 2014). In Latvia, the acquirable curriculum of Technologies is similar to the Craft curriculum (e.g., Käsitöö in Finland (Pöllänen, 2009) or Sloyd in Sweden (Borg, 2006)). In the context of a subject term, "Technologies" is understood as a processing of various materials (textiles, wood, metal, and others). In the Home Economics and Technologies standard it is defined as "For the acquisition of the technological process of product making, school offers two equivalent programmes for pupils that mainly differ in the choice of materials needed for product making and processing specifics: I technologies for textile and similar materials II - technologies for wood, wooden materials, metal and other similar materials" (Noteikumi par valsts pamatizglītības standartu, pamatizglītības mācību priekšmetu standartiem un pamatizglītibas programmu paraugiem, 2014).

An extensive education reform is being implemented for a transition toward a competence approach (Izglītība mūsdienu lietpratībai: mācību satura un pieejas apraksts, 2017), which affects each subject and the learning process in general; therefore, it is necessary to cover not only the foreign studies but also comprehensive research in education, including identification of public opinion.

The goal of this study is to explore Latvian public opinion on the acquisition of materials processing technologies in comprehensive schools by finding out what Latvian society understands by a qualitative process of materials processing technologies' acquisition.

In the "Explanatory Dictionary of Pedagogical Terms" (Blinkena, 2000, p. 90) quality is defined as "An indication, feature or set that characterises compliance of a subject, phenomenon or process to certain predetermined 
(imposed) requirements. In the pedagogical process the quality of consecutively related processes and their results is of vital significance."

The unique situation of Latvia in the context of the EU and the world should also be taken into account, and an appropriate model of materials processing technologies should be created. Fadels, Bialika, and Trilings (2017, pp. 34-36) indicate that for a $21^{\text {st }}$ century learning programme to be truly holistic, it should contain and be able to balance different educational objectives. The authors present numerous examples, from which the most important ones for this study are: balance between modern knowledge and traditional subjects; balance between profundity and breadth; balance between natural sciences, technologies, engineering, mathematics (STEM), and the humanities and art; balance between mind and body; balance between knowledge, skills, character, and meta-learning; and balance between outcome and process. One questions is: what modern knowledge should be included in the Home Economy and Technologies subject, and how profoundly and extensively each topic in the Home Economy and Technologies content should be learned. A balance between natural sciences, technologies, engineering, mathematics (STEM), and the humanities and art should be found in the very subject of Home Economy and Technologies. As M. Urdzina-Deruma (2001) has investigated in her doctoral thesis, textile technologies should be learned in the framework of artistic education. Acquisition of other materials processing technologies can be justified similarly, because artistic means of expression and principles are used when creating products; consequently, it is a language of art. Luutonen, et al. (1999, p. 7) and Ihatsu (2002, pp. 54-77) show the close link between art, design, and craft. Ihatsu (2002) writes that craft and art have close points of contact, art-craft being the intermediary between the two. The close correlation between craft and art is indicated also by the fact that in Norway there's a subject called "Arts and Crafts" (Lutnces, 2013, p. 76). In the currently proposed content model within the framework of project "Competence approach in the learning content" (Izglītība mūsdienu lietpratībai: mācību satura un pieejas apraksts, 2017) the learning content of Home Economy and Technologies is included in the domain of "Technology", not "Art and Cultural Awareness". It is similar to Estonia, where subjects related to handicraft are included in the domain of technology. "Although the name of the domain suggests a technical orientation of the subject, the content pays a lot of attention on developing the creative side. It is important to point out that the syllabus indicates the connections between handicraft and applied art" (Lind, 2013, p. 156). Anspaks (2006, p. 250) alerts us about the pressure of one-sided intellectualism, rationalism, and the prevailing technocracy and practicism. Traditionally, in the subject content the cultural dimension 
was of great importance, as indicated also by Lind (2013, p. 156). Finnish researcher Ihatsu (2002, p. 54) has explored that handicraft has always been an important part of culture. Latvia has adopted the Intangible Cultural Heritage Law (2016), which determines that intangible cultural heritage, including traditional craft skills, should be incorporated in both formal and informal education. What is stated in the law relates to Anspaks' (2006, p. 23) idea that without unity of change and preservation principles and their interaction it is not possible to achieve a genuine implementation of educational opportunities. In theory and practice of any cultural domain, inheritance and succession help to retain thoroughness.

In relation to the example suggested by Fadels, Bialika, and Trilings, in the search for balance between mind and body, Home Economics and Technologies gives the chance to practice a healthy diet as well as develop the mind, sight, and hands in a coordinated manner. In Home Economics and Technologies, possibly more than in other subjects, the acquisition of learning content can be balanced with practical skills applicable in the real world, and it can stimulate the development of character traits. Swedish researcher Johansson (2006, p. 169) has explored that in handicraft lessons the learning process is very similar to life situations outside the classroom. The final result is directly related to the pupils' working process. Very often the outcome is a product that can be practically used.

By learning technologies, it is very important to apply a balance between results and processes. In the opinion of the authors, it means paying equal attention to the creation process of the product by taking the product design, formation of composition, selection of materials, and technique/technologies, as well as experimental opportunities and aesthetic and technically qualitative results into consideration. Only then does the product give pleasure and satisfaction, and develops patience and other important character traits. Fadels, Bialika, and Trilings (2017, p. 5657) point out that each subject holds three value aspects: 1) the practical aspect that is related to applicability in everyday life; 2) the cognitive aspect that refers to the development of the highest level and development of character; and 3) the emotional aspect reflecting the fact that the subject possesses beauty and power to help understand the world. Crafts are related to many spheres of life. The model provided by Kaukinen (2006, p. 149) shows the necessary skills for craft-making from material to cultural artifacts. The development of craft design skills is influenced by the culture, technologies, and the personal skill to make decisions and experience in the creation of craft design. Borg (2006, pp. 42-45) points out that an essential part of the craft (Sloyjd) subject identity is the aesthetic aspect; craft education promotes aesthetic preparedness, and it develops an understanding of how selection of the material, processing, 
and designing affects the functionality and durability of the objects. Pupils should be educated about the environment, safety, and the importance of prudent use of resources. Teaching should be tied to the national cultural heritage of handicraft and foreign cultures. Handicraft belongs to the cycle of aesthetic subjects.

Finland's craft science model defines domains that need to be respected, because craft products are related to several aspects: cultural; social; temporality; environmental; and economic. The tangible and intangible characteristics of a craft product are interlinked. Their inseparability is reflected in the concept of aesthetics. The aesthetic qualities are dependent on the material, structure, method of creation, and the cultural perception of the material's characterisation. (Luutonen, et al., 1999, pp. 3-6). The aesthetic quality of the product is also taken into account when assessing pupils' craft products (Syrjäläinen \& Seitamaa-Hakkarainen, 2014). Similar to craft product, craft science is related to many sciences: psychological; cognitive; social; cultural-historical; and socioeconomic, as well as the natural sciences' and technologies' dimensions of human activities (Luutonen, et al., 1999, pp. 3-6).

As Elorinne, Arai, and Autio $(2017,145)$ point out, "Home Economics is constructed as both a practical discipline and as a human science. The field of Home Economics has a specific cultural research object: the household and its activities".

In today's global context the skills to be acquired in the $21^{\text {st }}$ century are defined; they can be broadly acquired in the Home Economics and Technologies subject. Finnish researchers distinguish two types of craftmaking processes: the holistic one that includes generation of an idea, experiments, creation of the product, and analysis of the result, as well as the ordinary one, where the handicraft is being made by following a sample. Pöllänen (2009) looks at four pedagogical models for learning craft at school: craft as product-making; craft as skill and knowledge-building; craft as design and problem-solving; and craft as self-expression. In each of these pedagogical models, the teacher's role is different. In the model of craft as product-making the teacher uses already-prepared samples called "ordinary craft" because in most cases the technique and materials are already defined. Craft as skill and knowledge-building is like a transitional phase between ordinary craft and holistic craft. The greatest emphasis is laid on skill acquisition in dealing with materials and techniques. Craft as design and problem-solving fully complies with holistic craft, because it includes solving a real problem, generating an idea, experimenting with materials and techniques, and making a design product with a practical function. The model of craft as self-expression also complies with holistic craft: in this model, the emphasis is on pupils' self-expression in the 
process of product creation, whereas the teacher is responsible for creating a supportive environment.

Root-Bernstein's study (2015, pp. 206-207) shows that “... here is a compelling statistical correlation between the highest levels of creative success and entrepreneurial endeavors in mathematics, science, and engineering and persistent participation in arts and crafts from childhood through Professional training and into career years. ...Arts and craft provide STEM students and professionals with (1) mental skills such as observing, imaging and abstracting, (2) sensual and manipulative skills, (3) analogies that provide novel approaches to solving STEM problems, (4) experience with materials, structures, phenomena and techniques, (5) practice with creative process; and (6) recreation to relax and re-energise their minds".

In the framework of education reform, the question of gender equality has become highly topical. By designing the content of future material processing technologies, an idea that all pupils should acquire all subject content has been put forward. However, Kalke, and Gonzalez Urrea (2016, p. 64) have explored that gender-differentiated education owes its origins to the ancient world (Mesopotamia), and such a way of learning had been particularly apparent in the Middle Ages. Presently, such an organization of educational activity is being practised in many countries, where boys and girls are learning separately. These may be schools, grades, or separate lessons where pupils are differentiated by gender. Historically, the Home Economics and Technologies subject was officially divided according to gender starting from the $5^{\text {th }}$ grade. For certain periods, that had started from the $4^{\text {th }}$ grade. As of 1998, the content of learning is not divided according to gender; in grades 1-4 all pupils learn the subject together but starting from the $5^{\text {th }}$ grade each pupil can choose whether to learn textiles and other similar materials or wood, metal technologies, and other similar technologies, but all of them should acquire Home Economics (Mājturība. Pamatizglìtības standarts, 1998; Noteikumi par valsts pamatizglìtības standartu, pamatizglìiîbas mācību priekšmetu standartiem un pamatizglìīibas programmu paraugiem, 2014).

\section{The methodology of the study}

A questionnaire was used in the study. The questionnaire contained multiple-choice questions and open questions. The questionnaire was distributed in paper format and over the internet. The respondents were asked to fill out the questionnaire to express their opinion with the aim of developing the learning content of Home Economics and Technologies. The pilot study was carried out from March 2017 to May 2017. Then the acquired data were analysed and more questions were added to the questionnaire. 
The basic study was carried out from June 2017 until April 2018. The aim of the research was to find out what the Latvian public understands with the acquisition of a high-quality Home Economics and Technology subject.

Questions of the study:

- In the view of respondents, what is a qualitative process of Home Economics and Technologies acquisition?

- What qualities does acquisition of Home Economics and Technologies develop in pupils?

- Where is the knowledge, skills, and competencies gained in Home Economics and Technologies used/applied?

- Which material processing technologies need to be included in the content of Home Economics and Technologies?

- In what directions should the content of Home Economics and Technologies be developed?

- Should all pupils learn an identical content of learning in Home Economics and Technologies or is an optional choice necessary?

- Which of the pedagogical models of handicraft learning suit to the expectations of Latvian society?

Both qualitative and quantitative methodologies have been used in the study. According to the methodology of the qualitative study, respondents' answers to the open questions were gathered in tables and grouped by making up categories (Kroplijs \& Raščevska, 2010). Then the categories were analysed quantitatively, whereas the answers to multiple-choice questions were analysed quantitatively.

\section{Characterisation of the respondents}

The respondents totaled 1,068: 942 or $88 \%$ were women and $12 \%$ or 126 were men. $68 \%$ of respondents had higher education, $12 \%$ had secondary professional education, $11 \%$ had secondary education, $6 \%$ had an unaccomplished higher education. The ages of respondents ranged from 15 to 92 years. Respondents represented all of Latvia: 33\% of respondents represented the small towns; 29\% represented Riga; 26\% represented the countryside; and 12\% represented the biggest cities of Latvia.

Occupations of the respondents participating in the survey were aggregated in accordance with the provisions regarding classification of occupations, basic tasks appropriate to an occupation and basic requirements of qualification (2017), where occupations were classified in accordance with the International Labour Organisation's (2008) International Standard classification of occupations ISCO-08, and were grouped into ten major groups in ascending order. Most respondents had occupations belonging to the second major group (see Figure 2). 


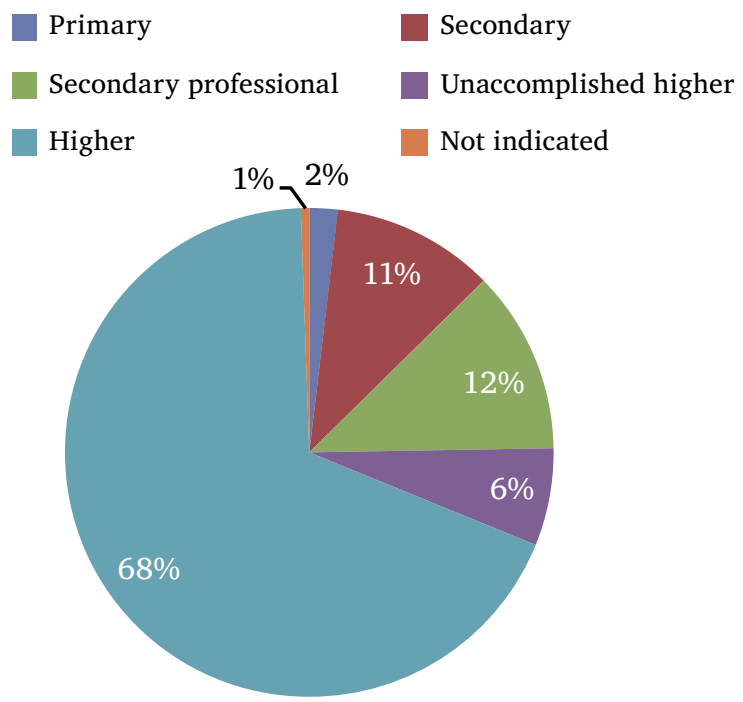

Figure 1. Education of the respondents

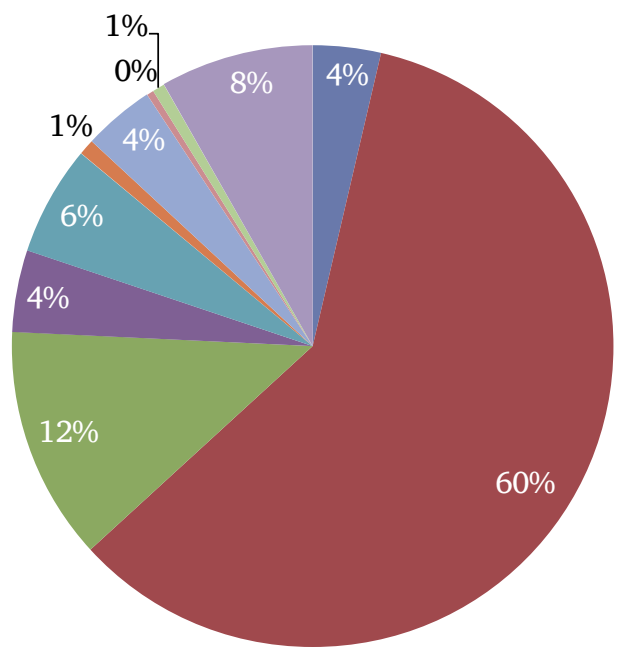

1. Heads of companies and institutions

2. Teachers, doctors, lawyers, scientists, artists, engineers, etc.

3. Specialists of various domains, technologists, culture professionals

4. Clerks, administrators, secretaries, accountants

5. Employees of service sector

6. Farmers, pisciculturists, forest labourers

7. Craftsmen, woodworkers, handicraftsmen, florists, tailors

8. Drivers, machine-operators

Figure 2. Occupations of the respondents

\section{Results of the study}

$90 \%$ of respondents thought that Home Economics and Technologies is an important subject, 6\% thought that it is an unimportant subject, $4 \%$ gave other replies. Respondents' answers testified that the Home Economics and Technologies subject has had a significant role in their lives, and for $36 \%$ of respondents it had influenced their choice of profession, for $68 \%$ 
of respondents it had influenced the choice of a hobby, and for $74 \%$ of respondents it had influenced their everyday lives.

For $32 \%$ of respondents the most important category for describing a qualitative acquisition process of Home Economics and Technologies was the teacher (see Figure 4), such as their competence, engagement, creativity, positive attitude, novelty, the ability to engage, experience, the teacher's personality, and talent (see Figure 3). Some respondents named several qualities that are important for a teacher, for example:

S17 A professional, creative and inspiring teacher.

J26 A proficient and creative teacher.
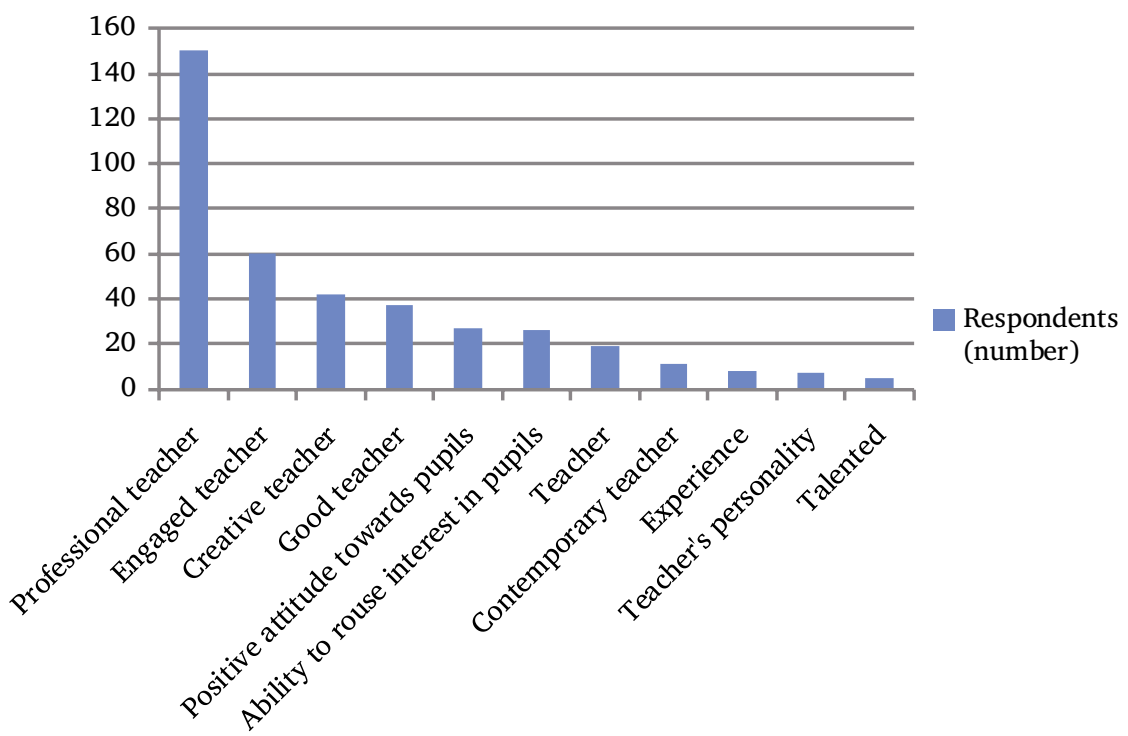

Figure 3. Respondents' views concerning the teacher - provider of qualitative Home Economics and Technologies subject

$24 \%$ of respondents thought that the most important category for describing the quality of Home Economics and Technologies was a qualitative material supply base, accessible materials, and the latest technologies. Respondents expressed it in various ways by mentioning it generally or by giving specific examples referring to the learning of a specific technology.

M15 A spacious, qualitative and modern material supply base

K5 Well-equipped rooms with all necessary equipment (sewing-machines, looms, kitchen, stoves, furnaces)

MK17 Workbenches should be available at schools where pupils can practice wooden and metal works 
119 respondents pointed out that quality was reflected by motivated and engaged pupils. Fewer respondents (106) thought that the indicator of quality was the fact that the mastered skills could be applied in the household. It follows that $1 / 10$ of all respondents thought that the subject should teach skills applicable in the household. A comparatively small part of respondents viewed the quality of the subject as skills achieved by the pupil and the pupil's ability to make use of the learned skills (94 respondents). 80 respondents thought that qualitative acquisition of Home Economics and Technologies was proven by novelty in content and implementation. 66 respondents mentioned creativity as a category representing quality. Ihatsu wrote (2002, p. 18) that the process of handicraft creativity is understood as an extensive and integrated phenomenon. 63 respondents pointed out practical work as a category of quality. As a category representing quality 45 respondents indicated this result, whereas 44 respondents indicated enjoyment of pupils attending Home Economics and Technologies classes. A similar number of respondents $(31,29,28)$ mentioned application of skills, production of products and, application of up-to-date technologies, respectively, as a category of quality (see Figure 4).

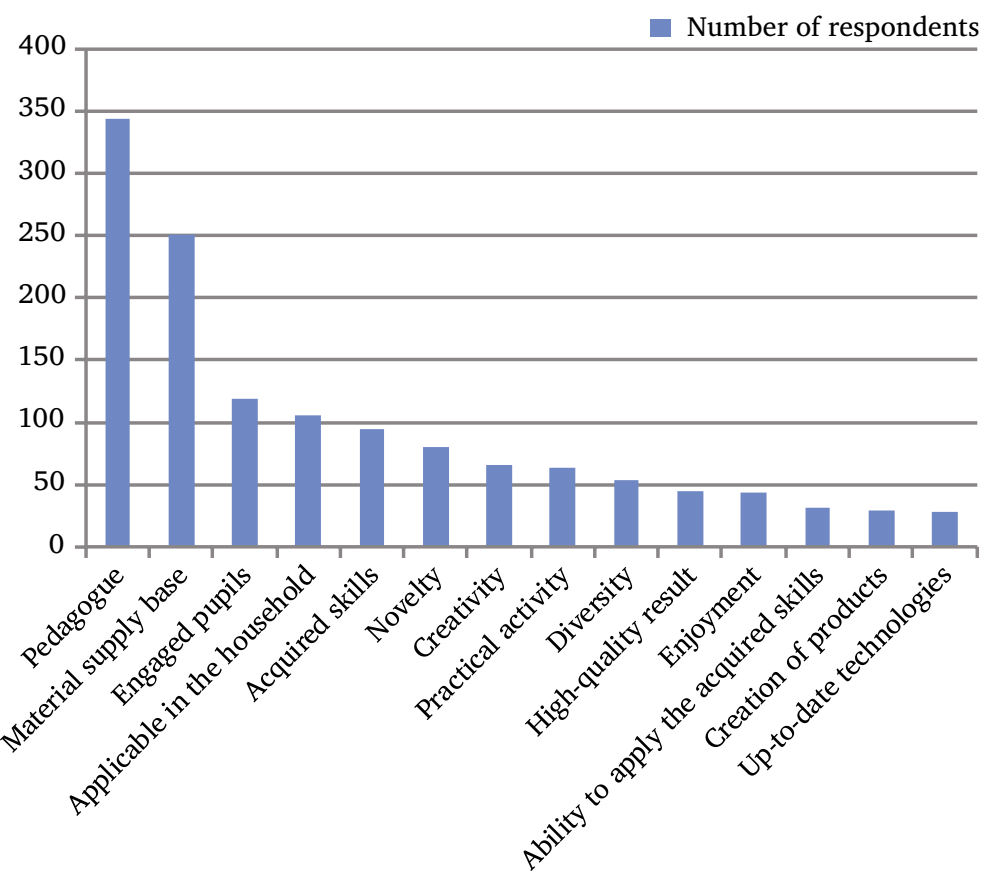

Figure 4. Respondents' views concerning categories that represent qualitative acquisition of Home Economics and Technologies subject 
The obtained results comply with Ihatsu's opinion (2002, p. 23-24) that acquisition of skills is an emotional, intellectual, and physical process, instead of just a mechanical process, and that acquisition of practical knowledge is a slow process. Tacit knowledge is always contained in practical skills, and it is fundamentally necessary for society to create ideas. This knowledge is learned by senses and practical experience.

Just a few respondents (less than 1\%) characterising quality of Home Economics and Technologies mentioned the learning programme, diversity of topics, assessment of pupils' learning achievements, exhibition of their works, achievements in olympiads, division and non-division in genders, implementation of cross-curricular links, use of excursions, as well as the use of knowledges and skills gained in Home Economics and Technologies when choosing a hobby or a profession, inheritance of traditional culture, and parents' attitude toward the subject (see Figure 5). 5\% of respondents did not answer this question.

Respondents' answers prove that in Latvian society a comparatively large percentage of people are engaged in various types of handicraft

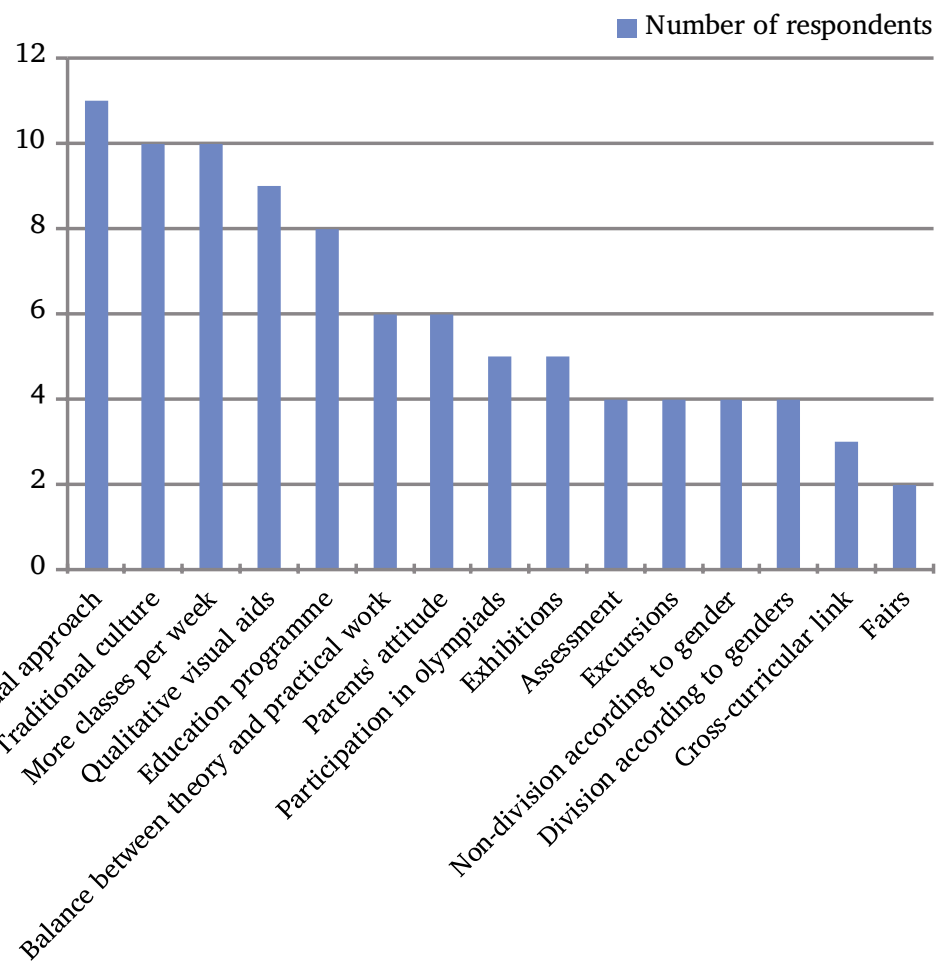

Figure 5. Respondents' views concerning categories that represent qualitative acquisition of Home Economics and Technologies subject 
because $94 \%$ of respondents did repair works, 93\% made various products manually, and $86 \%$ made various handicraft together with children.

In the context of education reform, the issue of whether all pupils should learn all topics has caught attention. Respondents held different viewpoints on this question: $48 \%$ of respondents thought that pupils should be given a choice to learn the technologies as before, whereas $41 \%$ of respondents thought that all pupils should learn all topics. $11 \%$ of respondents gave a different answer.

The highest share of answers to the question "What teaching topics were absent in Home Economics and Technologies that you would like to learn?" was related to textiles (42\% of all respondents; $46 \%$ of women and $10 \%$ of men). Many respondents emphasised that they would have liked to have had more classes and they would have liked to have learned sewing and traditional handicraft like knitting, crochet, embroidery, weaving, and card weaving in greater depth. Many respondents noted that they would have liked to have learned these techniques according to modern technological possibilities and new materials. For example, in knitting - loom knit; in embroidery - ribbon embroidery or machine embroidery; and in weaving - pearl weaving. Many textile techniques were named in relation to fashion trends, such as textile mosaics, various creative decorative techniques of fabrics, pearl knitting, and synthesis of various textile techniques. Many respondents wanted to learn such fabric decorating methods as printing, batik, and silk painting. Related to sewing, basic knowledge of sewing, clothing construction and modelling, as well as clothing culture, etiquette, and care of clothes were mentioned. Some specific products were also mentioned as ones that should be learned in greater depth, such as knitting of socks and caps and weaving of dolls. It was also requested to dye yarns with natural and synthetic dyes.

The second most popular topic was wood and metal $(32 \%$ of respondents). This category was mostly mentioned by men (48\%) and $30 \%$ of women. Women believed that girls should be taught "boys' works and learning topics" like woodworking and metal. Girls should learn the traditional working tools and skills of these materials. Women held an opinion that girls should also know how to carry out small repairs indoors, as well as repairs of electrical devices and furniture. Some respondents named specific skills like how to hammer in a nail, how to screw, turn, shave, etc. Men held an opinion that skills in work with electrical machinery and electrical devices should be learned in terms of both using and repairing them, and basics of electrical installations should be learned. In woodworking specific skills and processing types, such as joinery, wood-carving, and wood-engraving were mentioned. Such skills as repairing domestic appliances and rooms were also named. 
Men suggested also knowledge of plumbing works and learning of specific materials and skills, such as stone engraving. Both women and men mentioned driving skills and car mechanics. The need for technical graphics skills was also named for the purpose of reading technical drawings and designing.

The third largest category was related to various materials, their application, new technological opportunities, and development of specific skills and competencies ( $23 \%$ of respondents). Respondents named ceramics and clay modelling, decoupage, floristics and flower arranging, leather processing, bookbinding, candle-making, glass painting, wicker-work, giftwrapping, and preparation of greeting cards. Unspecific formulations related to new materials, trends, and topicalities were also pointed out. Multipleuse materials, new materials, "from defect to effect", transformation of materials, and application of ecological materials were mentioned. Specific materials and skills, such as painting and alternative methods of painting, glass painting, cosmetology and henna drawings, photography, fishing, etc. were also named.

The fourth category (21\%) represented very unspecific answers that are not related to the content of Home Economics and Technologies. For example, "we learned the basics of everything", "that was my favorite subject", "I learned all feminine skills", "I learned in Lithuania", "it covered all topics", "the fashion trends are changing", "I don't remember", "I don't have an opinion", and "each topic needs more time".

The fifth most popular category was nutriment (18\% of respondents). Most respondents suggested that there should be much more practical training in cooking, that emphasis should be put on healthy diet and lifestyle, on creating menus, and correct preparation of healthful food. Inclusion of hospitality, table manners, and etiquette were also mentioned. Specific topics such as preparation of dairy dishes, various cuisines, cooking of popular and modern meals, preservation, confectionery, herbal teas, and e-substances were marked. Men specifically emphasised the necessity of practical cooking skills.

The sixth most relevant category was household and home economics (11\%). A wish related to agricultural topics such as horticulture and floriculture was specifically expressed. Other topics were related to the planning of budget and resources, upholding and managing of the household, waste sorting and application of household chemicals, inventory of readings, and indoor repair works and furniture repair.

With less proportion (3\% and less), such categories as ethnography, interior design, composition and color teaching, life skills, establishment of a family, and childcare were mentioned. Very little attention was paid to the category of technologies, computers, and equipment. See Figure 6. 


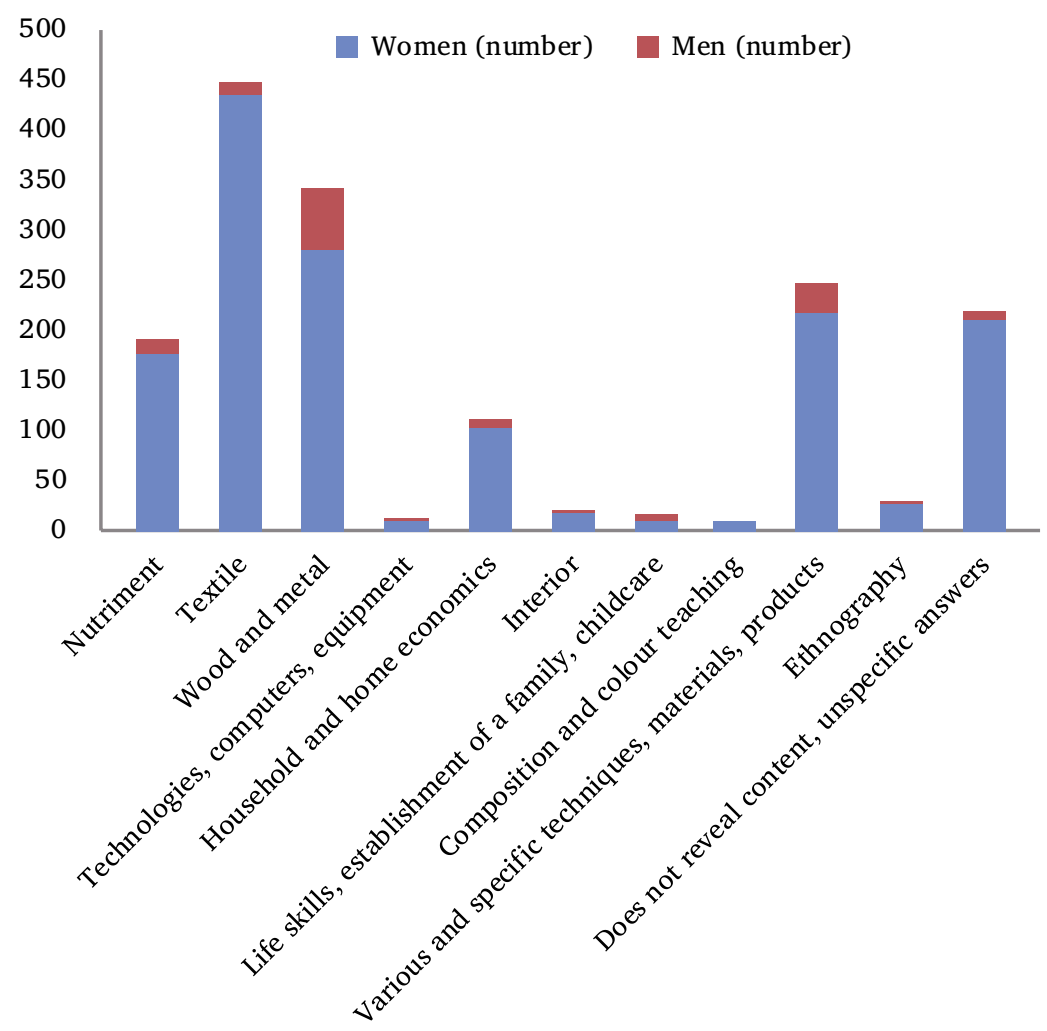

Figure 6. Respondents thoughts about teaching topics that were absent in Home Economics and Technologies and that they would like to learn

Related to the question of what topics should be definitely acquired, the most popular answer was nutritional education, pointed out by 643 respondents (60\% of respondents). As respondents' answers differed in terms of gender, they were further analysed for each gender separately. The largest percentage of women (65\%) indicated nutritional education as a compulsory subject, followed by sewing (35\%), knitting (30\%), crochet (20\%), and clothing (16\%). Attention should be paid to the fact that $12 \%$ of women indicated "all handicraft" as a compulsory subject. Whereas men mostly mentioned woodworking ( $38 \%$ of men), followed by nutritional education (24\%), metalworking (23\%), technical drawing (18\%), and electricity (14\%). See Figure 7.

The respondents' answers related to the question in which directions the subject should be developed did not significantly differ by gender. A strong focus was on content development (17\%). 15\% of respondents wanted more practical tasks, making products that can be utilised in everyday life. $12 \%$ of respondents would not change anything; Home Economics and Technologies 


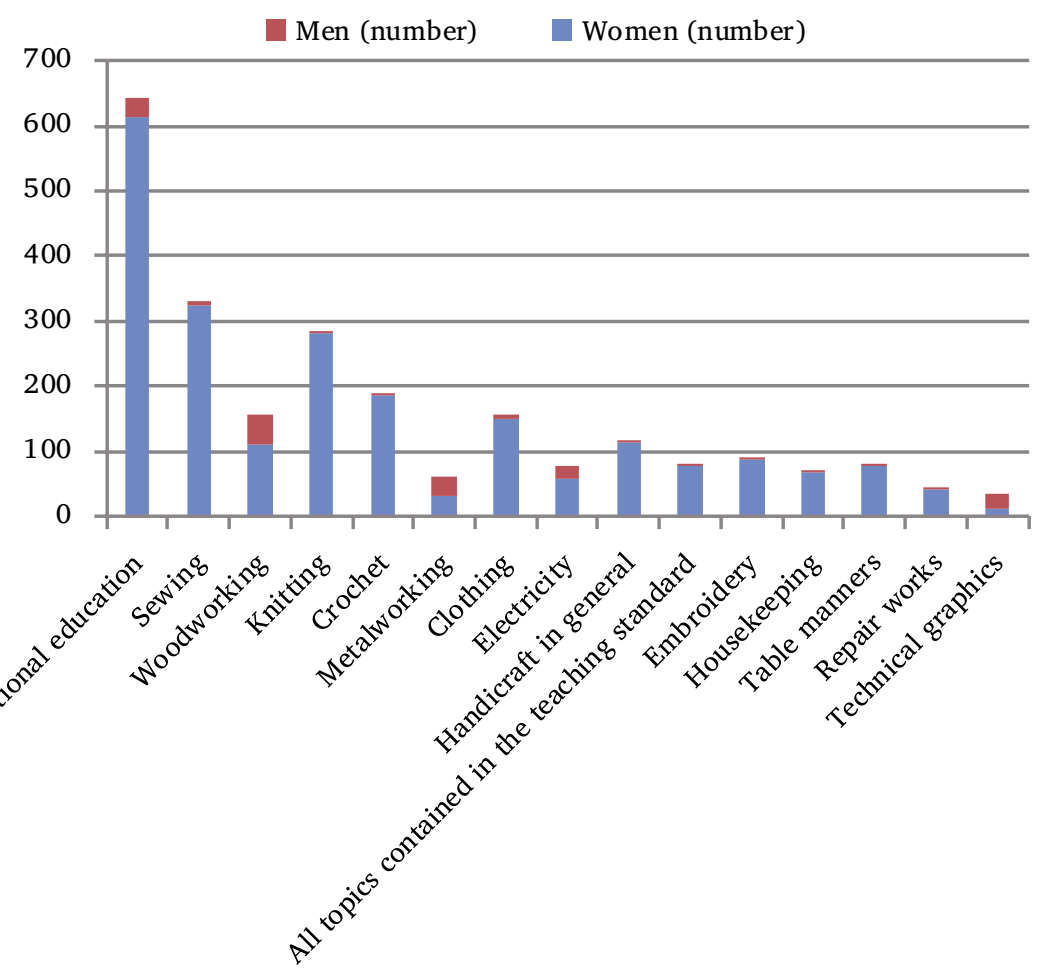

Figure 7. Respondents' views concerning learning topics that should definitely be included in the content of Home Economics and Technologies subject

had been their favorite subject. $12 \%$ of respondents suggested an improved methodology, stimulation of greater interest, use of educational excursions, teamwork, an introduction of a teacher's assistant, and more freedom of choice to pupils. The respondents' answers prove that $9 \%$ of them wanted to bring in more innovation, freedom of choice, creative works, a creative approach, new types of handicraft, opportunity for teachers and pupils to diversify more, diversity, and multilateralism. 9\% of respondents answered that they did not know what they would change as they had no direct link with school, they did not know the current programme, and the situation in each school differs. 7\% of respondents suggested introducing more classes per week as well as introducing it as a compulsory subject also in secondary school, and increasing the number of classes for those who want to get an in-depth learning. $6 \%$ of respondents suggested not breaking the subject by genders, to teach boys some theme elements that are tailored for girls and vice versa, common activities for boys and girls, and classes divided into groups to ensure individual work. $6 \%$ of respondents wanted less volume of work, more work in classes and more adjustment to each pupil 
according to his/her skills. 5\% of respondents suggested improving the material supply base, better-equipped workshops, innovative technologies, and implementation of modern materials. $3 \%$ of respondents suggested reviewing the assessment, putting enrolled/non-enrolled instead of marks, and assessing attitude and work according to accomplishments during the class (see Figure 8). Similar results were obtained from the interviews $(N=14)$ with Latvian students who have been in the student exchange programme in foreign universities. The results shows that the greatest number of suggestions (19 content classifiers from 49) is in the category 'Supplement curriculum'. Students suggest different content aspects for development of the Home Economics and Technologies: introducing other techniques, such as felting and bead crocheting, the use of untraditional and recycled materials, and combining wood, textiles, and metal. Three stress modern elements. The next most-frequently mentioned categories are 'Supplement teaching methods' (10 content classifiers), 'Improve material availability' ( 9 content classifiers) and 'Encourage student self-expression' (5 content classifiers) (Urdziña-Deruma, Šelvaha, 2018).
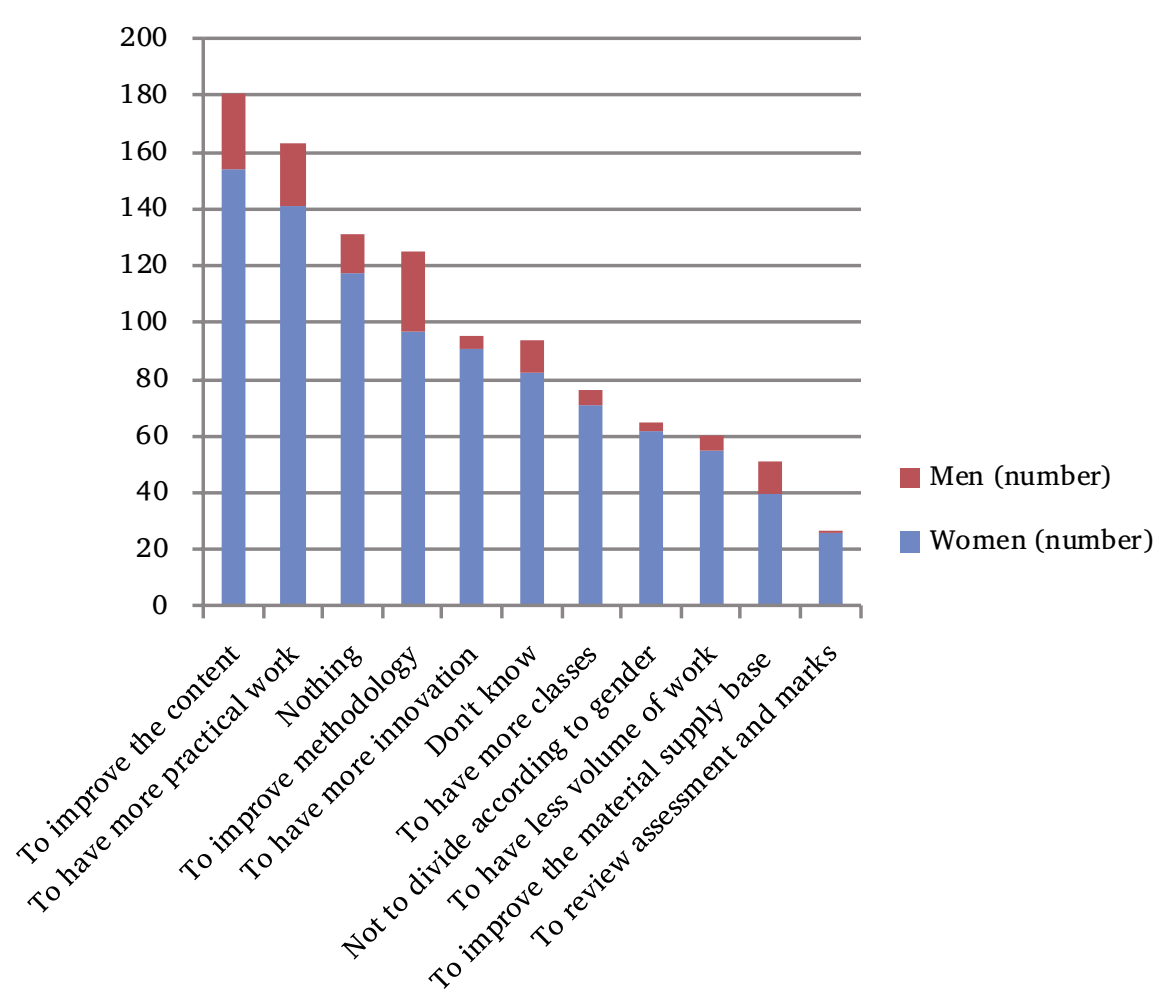

Figure 8. Respondents' views on the development of Home Economics and Technologies subject 
According to the respondents, the most important and essential contribution of Home Economics and Technologies in the education of pupils (339 respondents) was skills and competencies that can be applied in the household. The term "life skills" often appeared in the answers.

As the most important aspect many (242) respondents mentioned specific practical skills in various handicraft techniques, work with different materials, instruments, and creation of various useful products. Many respondents (115) thought that the main aspects were creativity, development of creative thinking, and the ability to express and implement ideas. Almost as many respondents indicated theoretical and practical knowledge as a benefit. Many respondents stressed the importance of handicraft by pointing out that it is important to create things, not just look at them on the Internet. Manual work improves motor coordination. Apart from that, development of fine motor skills in fingers has been mentioned as the main benefit. 55 of respondents thought that the greatest benefit was the gained experience that serves as a foundation for independent living. Many respondents (53) pointed out it is very important that pupils learn to comprehend how things are made and thus evaluate them. In some responses, the ability to work according to a scheme, technical drawing, description, and instructions were mentioned. Development of mind and thinking was named as a benefit. By practical working, the logical and dimensional thinking is
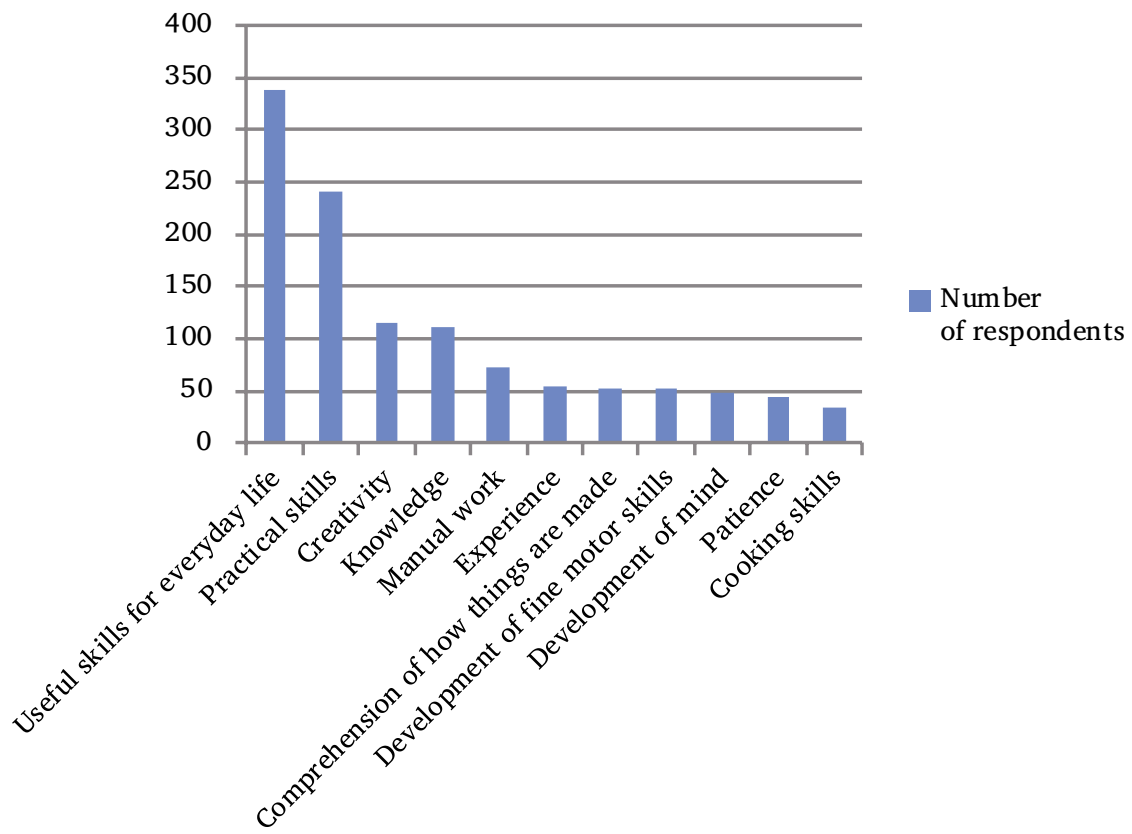

Figure 9. Respondents' views on the main benefits pupils gain by learning the content of the Home Economics and Technologies subject 
trained. Respondents pointed out that the impact of Home Economics and Technologies on the development of positive character traits is very important; it stimulates patience, precision, and accuracy, self-dependence, self-confidence, responsibility, attention, diligence, and sense of taste. Learning cooking skills, including table setting and awareness of nutritional education, was separately pointed out as a special benefit (see Figure 9).

Responses that were mentioned fewer than 30 times were not included in the figure. The mentioned benefits included: deriving insight into various occupations; chance to find one's own hobby; identification of interests and talents; learning of historical heritage and traditions; getting prepared for family life; planning skills (regarding time and resources); and cooperation skills.

\section{Conclusions}

The results of the study show that Latvian society considers the teacher's competence and material supply provision of workshops as the main aspects of ensuring a quality Home Economics and Technologies subject. As for the most substantial contribution in pupils' teaching, respondents see skills that can be applied in the household. It shows that according to the theory about pedagogical models of handicraft education (Pöllänen, 2009) the expectations of Latvian society mostly conforms to the model "Craft as skill and knowledge building". It shows that Latvian society expects to acquire existentially important skills from this subject. A comparatively small portion of respondents emphasised creation of specific products, creation of design objects, and craft as learning of artistic self-expression. There were comparatively few responses indicating the importance of the aesthetical aspect. When responding to the question on what changes respondents would like to see in the subject, the majority of respondents wanted to have more practical work. Respondents had varying views on whether all topics that had traditionally been optional for pupils should be learned by all pupils equally. To a large extent, it relates to the differences appearing in men's and women's responses about the necessary learning topics. A majority of female respondents thought that nutrition should be a compulsory topic (65\%). This was followed by sewing, knitting, crochet, and clothing. A majority of the male respondents indicated woodworking (38\%), followed by nutritional education, metalworking, technical graphics, and electricity. There was a contradiction regarding the fact that learning about traditional cultural heritage was mentioned as a quality criterion by only a few (10) respondents, and as the most substantial benefit by 26 respondents, whereas when talking about topics that should be learned, the acquisition of traditional techniques prevailed. 


\section{References}

Anspaks, J. (2006). Mākslas pedagogíija. 2. daḷa. Metodologija. Teorija. Prakse (Art pedagogic. Part II. Methodology. Theory. Practice). Rìga: RaKa.

Blinkena, A. (Ed.). (2000). Pedagogijjas terminu skaidrojošā vārdnica: aptuveni 1500 terminu latviešu, anglu, vācu un krievu valodā (Explanatory Dictionary of Pedagogical Terms: 1500 terms in Latvian, English, German and Russian). Sast. aut. kol. Valentīnas Skujinnas vadībā. Rīga: Zvaigzne $A B C$.

Borg, K. (2006). What is sloyd? A question of legitimacy and identity. Theme: SloydTradition in transition. Journal of Research in Teacher Education, 2-3, 34-61.

Elorinne, A.-L., Arai, N., \& Autio, M. (2017). Pedagogics in Home Economics meet everyday life: Crossing boundaries and developing insight in Finland and in Japan. In: E. Kimonen, \& R. Nevalainen (Eds.), Reforming Teaching and Teacher Education: Bright Prospects for active Schools (pp. 145-168). Sense Publishers.

Fadels, Č., Bialika, M. \& Trilings, B. (2017). Četru dimensiju izglīïba: Skolēnu panākumiem nepieciešamās kompetences (Four-Dimensional Education: The Competencies Learners Need to Succeeded). Lielvārde: Izglītības uzñēmums "Lielvārds".

Ihatsu, A.-M. (2002). Making sense of contemporary American craft. Publications in education, 73. University of Joensuu.

Izglīî̉a mūsdienu lietpratībai: mācību satura un pieejas apraksts (Education for contemporary competence: description of the content of learning and approach). (2017). Retrieved from https://domaundari.lv/cepure/Macibu\%20satura\%20un\%20pieejas\%20 apraksts.pdf.

Johansson, M. (2006). The work in the classroom for sloyd. Theme: Sloyd-Tradition in Transition. Journal of Research in Teacher Education, 2-3, 152-171.

Kalıke, B., \& Gonzalez Urrea, J. (2016). Dzimumdiferencēta izglītība pedagoơiskajā procesā (Single Gender Education in the Pedagogical Process). Latvijas Universitātes Raksti, 811. sēj. Pedagogija un skolotāju izglitïba (Scientific Papers University of Latvia, Vol. 811. Pedagogy and Teacher Education), 59-66.

Kaukinen, L. (2006). Domains of skills and craft design. In: A.-I. Rauma, S. Pöllänen, \& P. Seitamaa-Hakkarainen (Eds.), Human Perspective of Sustainable Future (pp. 143-151). University of Joensuu.

Kroplijs, A. \& Raščevska, M. (2010). Kvalitativās pētniecibas metodes sociālajās zinātnēs (Qualitative research methods in the Social Sciences). $2^{\text {nd }}$ ed. Rìga: RaKa.

Lind, E. (2013). Possibilities for creative self-actualisation in craft. Differences and similarities in handicraft in the $19^{\text {th }}$ and $21^{\text {st }}$ century in Estonian general education schools. The Changing Face of Music \& Art Education, 5(1), 149-159.

Lutnæs, E. (2013). Regimes of competence in the subject art and crafts. Techne Series A, 20(3), 76-87.

Luutonen, M. Koskennurmi-Sivonen, M., Koski, J. T., Raunio, A.-M., Kirsti SaloMattila, K., Seitamaa-Hakkarainen, P. \& Syrjäläinen, E. (1999). Research at the Section of Craft Science and Textiles Teacher Education at the University of Helsinki. Retrieved from https://rkosken.kapsi.fi/tyorukkanen-en.pdf.

Mājturïba. Pamatizglitibas standarts (Handicraft and Home Economics. Curriculum for elementary education) (1998). Latvijas Republikas Izglītības un zinātnes ministrija Izglìtỉbas satura un eksaminācijas centrs (Ministry of Education of Latvian Republic, Centre for the Content of Education and Examination). Rìga: SIA "Mācību apgāds NT". 
National curriculum for basic schools (2014). Estonia: Riigi Teataja. Passed 06.01.2011. Retrieved from https://www.riigiteataja.ee/en/eli/524092014014/consolide.

Noteikumi par Profesiju klasifikatoru, profesijai atbilstošiem pamatuzdevumiem un kvalifikācijas pamatprasībām (Regulations regarding the classification of occupations, basic tasks and essential qualifications of the profession). (2017). Latvija: Ministru Kabinets. Pienemts 23.05.2017. Retrieved from https://likumi.lv/doc.php?id $=291004$.

Noteikumi par valsts pamatizglitibas standartu, pamatizglitibas mācïbu priekšmetu standartiem un pamatizglitibas programmu paraugiem (Regulations regarding the National elementary education standard, elementary education subject standards and examples of elementary education syllabus) (2014). Latvija: Ministru Kabinets. Retrieved from http://likumi.lv/ doc.php?id $=268342$.

Pöllänen, S. (2009). Contextualising craft: Pedagogical models for craft education. International Journal of Art \& Design Education, 28(3), 249-260. DOI: 10.1111/ j.1476-8070.2009.01619.x.

Root-Bernstein, R. (2015). Arts and crafts as adjuncts to STEM education to foster creativity in gifted and talented students. Asia Pacific Education Review, 16(2), 203-212. Retrieved from https://doi.org/10.1007/s12564-015-9362-0.

Syrjäläinen, E. \& Seitamaa-Hakkarainen, P. (2014). The quality of design in $9^{\text {th }}$ grade pupils' design-and-make assignments in craft education. Design and Technology Education: An International Journal, 19(2), 30-39. Retrieved from http://ojs.lboro.ac.uk/ojs/index. php/DATE/article/view/1931/1972.

Urdziņa-Deruma, M. \& Mīlgrāve, I. (2014). Rokdarbu kā mākslas jomas vēsturiskā attīstība (Historical Devolopment Manual Training as a Branch of Art). Latvijas Universitātes Raksti, 795. sēj., Pedagoğija un skolotāju izglitïba (Scientific Papers University of Latvia, Vol. 811, Pedagogy and Teacher Education), 114.-129. lpp.

Urdziņa-Deruma, M. \& Šelvaha, L. (2018). Crafts and Home Economics studies abroad. Students identified differences and suggestions for teacher education in Latvia. International Journal of Smart Education and Urban Society, 9(4), 77-89.

Urdziņa-Deruma, M. (2001). Tekstils kā mākslas izglītības sastāvdalı topošo mājturïbas skolotāju studijās augstskolā (Textile as a Part of Art Education in the Studies of Future Teacher's of Handicraft and Home Economics in Higher Education Institution). Doctoral dissertation. Retrieved from https://dspace.lu.lv/dspace/handle/7/546.

Žukovs, L. (1987). Darbmācības satura attīstības tendences Latvijas vispārizglītojošajās skolās (Tendencies of developing Manual training content in LSSR general schools). In: Mācību un audzināšanas satura attīstības galvenās tendences Latvijas PSR vispārizglītojošajā skolā (Tendencies of developing of the content of learning in LSSR general schools) (pp. 72-89). Rīga: LPSR IM. 


\title{
MALADAPTIVE COGNITIONS, HYPERACTIVITY AND INCONSISTENT PARENTING AS RISK FACTORS OF ADOLESCENT PROBLEMATIC INTERNET USE
}

\begin{abstract}
The aim of this study was to examine the interrelationships of specific adolescent biological, environmental (parental), and cognitive factors in relation to adolescent problematic internet use (PIU). The design of the present study was influenced by the theoretical framework presented by Brand and colleagues (Brand, et al., 2016), who have proposed a multi-faceted model, including a vast number of interacting variables. This study was with the intent of focusing upon three possible risk factors suggested by this model. Participating in the study were 307 middle-school and high-school adolescents, who completed questionnaires regarding hyperactivity, parenting practices, and maladaptive cognitions. After controlling for age, gender and family economic status, regression analysis showed hyperactivity, inconsistent parenting, and maladaptive cognitions to be predictive of PIU. Maladaptive cognitions were shown to partially mediate the effect between insonsistent parenting and PIU. Results are discussed in regard to the necessity of considering multiple prevention and treatment approaches in light of the various PIU risk factors within the neuropsychological, familial and cognitive domains.
\end{abstract}

Keywords: Problematic internet use, Hyperactivity, Parenting practices, Maladaptive cognitions.

\section{Introduction}

Internet use is becomming an ever more increasing and almost indispensable part of an adolescent's daily life. This includes the necessity of using the internet for academic purposes in completing school assignments, but also for daily communication with peers and parents. As a result of the 
increased use of the internet, the risks of internet overuse and development of internet dependency are augmented. Recently researchers of internet use (Brand, Young, \& Laier, 2014; Brand, et al., 2016; Davis, 2001) have developed several models depicting an integration of internet dependency risk factors, including neurobiological, experiential, affective and cognitive components contributing to internet use disorders, and these models have helped to provide a theoretical framework for the present research study.

Two decades have passed since Kimberly Young (Young, 1998) began to examine the potential psychological dangers and the severe psychosocial problems which can result from excessive internet use. Since this initial acknowledgment of the potential psychological difficulties associated with intensified internet use, various terms have been applied to these difficulties, including Internet addiction, Internet addiction disorder, Problematic internet use (PIU), Pathological internet use, and Compulsive internet use (Ciarrochi, et al., 2016). In general, these terms similarly refer to an inability to exert control over one's use of the internet, with subsequent negative consequences for meaningful daily activities. Internet addiction or Problematic internet use shares similar symptoms with other addictive disorders, including preoccupation, uncontrolled impulse to engage, withdrawal phenomena, tolerance, excessive time and effort devoted to the addictive behavior, and negative social repercussions (Ko, et al., 2007; Pies, 2009).

The relationship between adolescent problematic internet use and predictive, concurrent or subsequent socioemotional difficulty has been examined in many parts of the world, with the use of both cross-sectional and longitudinal studies. In general, associations have been found between intensified, problematic internet use and a wide range of indices of mental health, including lowered self-esteem, loneliness, depression, anxiety and social phobia (Park, et al., 2008; Selfhout, et al., 2009). A cross-sectional study examining PIU in association with psychological impairments among European adolescents showed that suicidal behaviors (suicidal ideation and suicide attempts), depression, anxiety, conduct problems and hyperactivity/inattention were significant and independent predictors of PIU (Kaess, et al., 2014).

Previous studies of adolescent Problematic Internet use (PIU) in Latvia have shown direct associations with aggression, as well as associations with anxiety, dissociation and sexual concerns (Miltuze, Bite, \& Sebre, 2012). In Lithuania adolescent Problematic internet use (PIU) was found to be associated with negative emotionality and less satisfaction in friendships and familial relationships (Jusiene, Cesniene, \& Mordas, 2015). As a significant risk factor for the development of Internet addiction, Ko and colleagues have accentuated the importance of the amount of time spend in online gaming (Ko, et al., 2007). 


\section{Hyperactivity as a risk factor for PIU}

Hyperactivity has been linked to internet addiction in several previous studies, as indicated by meta-analyses investigating this association (Carli, 2013; Wang, et al., 2017). It has been shown that adolescents diagnosed with attention deficit hyperactivity disorder (ADHD) were more likely to be addicted to the internet than those with other difficulties such as agression or social phobia. Researchers have suggested that since one of the symptoms of ADHD is "being easily bored", the internet use may serve to alleviate feelings of boredom because it is possible to play several games simultaneously, or participate in several chat conversations within the same time frame. Another symptom of ADHD is increased impulsivity, and having an aversion for delayed rewards. This may facilitate internet addiction because the internet provides opportunity for receiving immediate stimulation and immediate rewards, such as game points. Also, as indicated by Brand and colleagues (Brand, et al., 2014; Brand, et al., 2016), differences in the prefrontal lobe brain activity of individuals with ADHD are linked to impaired inhibition and lack of self-control, which would make it more difficult for individuals with hyperactivity to stop using the internet once they have begun. Hyperactivity is largely considered to be genetically influenced, with genetic factors accounting for $73 \%$ of the variability in hyperactivity, as shown in a recent meta-analysis (Nikolas \& Burt, 2010).

\section{Parenting practices as a risk factors for PIU}

Parenting practices and other aspects of family functioning have been found to be associated with problematic internet use in numerous studies (e.g., Ko, et al., 2007; Yen, et al., 2007), and the results of these studies have indicated that higher parent-adolescent conflict, habitual alcohol use by siblings, and perceived parents' negative attitude toward adolescent substance use is predictive of PIU. Low family functioning and increased amount of online gaming has predicted the emergence of internet addiction. In contrast, emotionally supportive parenting style has been found to be predictive of a lower likelihood of internet addiction (Chen, Chen \& Gau, 2015; Park, Kim, \& Cho, 2008; Van den Eijenden, 2010). Negative experiences in the parent-child relationship have been linked to insecure attachment style, and insecure attachment has been found to be associated with internet use disorders (Schimmenti, et al., 2014). It has consistently been shown that emotionally warm and supportive parenting practices facilitate child mental health, whereas punishment oriented practices facilitate child internalizing and externalizing problems (e.g. Sebre, et al., 2014). In addition, inconsistent disciplining, when discipline 
may erratically fluctuate depending upon the parents' mood or the child's powers of persuasion, has also shown to directly contribute to child mental health problems and delinquent-oriented attitudes (Balan, et al., 2017; Halgunseth, et al., 2013).

\section{Maladaptive cognitions as risk factors for PIU}

Maladaptive cognitions have been linked to Problematic internet use in a theoretical model based upon a cognitive-behavioral approach. Davis (2001) has proposed that maladaptive cognitions can serve as a "main source" of maladaptive behavior, and can encourage maladaptive behaviors such as PIU. Davis frames his consideration of the role of maladaptive cognitions within the diathesis-stress model, whereby the individual's predisposing vulnerability is accelerated within stressful life situations. Specifically, Davis proposes that if a predisposing vulnerability such as depression or anxiety is coupled with a stressful situation such as lack of support from family and friends, these can be facilitating factors which thereby promote maladaptive cognitions. Similar to the types of negative cognitions proposed by cognitive-behaviouralists Ehlers \& Clark (2000), Davis considers the distinction between negative thoughts about the self, and negative thoughts about the world. Predisposing socioemotional factors, in conjunction with maladaptive cognitions, can facilitate overuse of the internet. This may be further augmented in situations where the internet user experiences positive reinforcement, for example, temporary relief from anxiety, and a fulfillment of internet-related expectations, such as being able to "make friends" more easily. The role of cognition, specifically agressive cognitions, has also been accentuated by Anderson and colleagues (Anderson, et al., 2017), who have found that the association between violent video-gaming and aggression is partially mediated by aggressive cognitions.

Integrated model of biological, social and cognitive risks factors for PIU

Several of the leading scientists concerned with internet addiction (e.g., Brand, Young, \& Laier, 2014) have acknowledged the significance of the cognitive-behavioral model proposed by Davis, but have elaborated upon this model by including neuropsychological mechanisms, specifically the control processes mediated by prefrontal brain areas. During the past decade there have been numerous studies linking PIU with executive functions, for example, difficulties in inhibiting automatic responses and difficulties with mental flexibility, i.e. set-shifting (Zhou, et al., 2012). Studies employing 
functional magnetic resonance imaging (e.g. Dong, et al., 2013) have shown that patients with internet addiction have reductions in decision-making performance, and this may contribute to their continuation of game playing even though they are confronted with negative consequences. Brand and colleagues (Brand, Young, \& Laier, 2014) have concluded that individuals with internet addiction may have reduced effectiveness of the prefrontal control processes, and this may be related to their loss of control over how many hours they spend engaged with the internet.

Brand has now expanded his team of collaborators (Brand, et al., 2016), and they have elaborated the theoretical framework in proposing the Interaction of Person-Affect-Cognition-Execution (I-PACE) model. This model includes several of the components initially proposed by

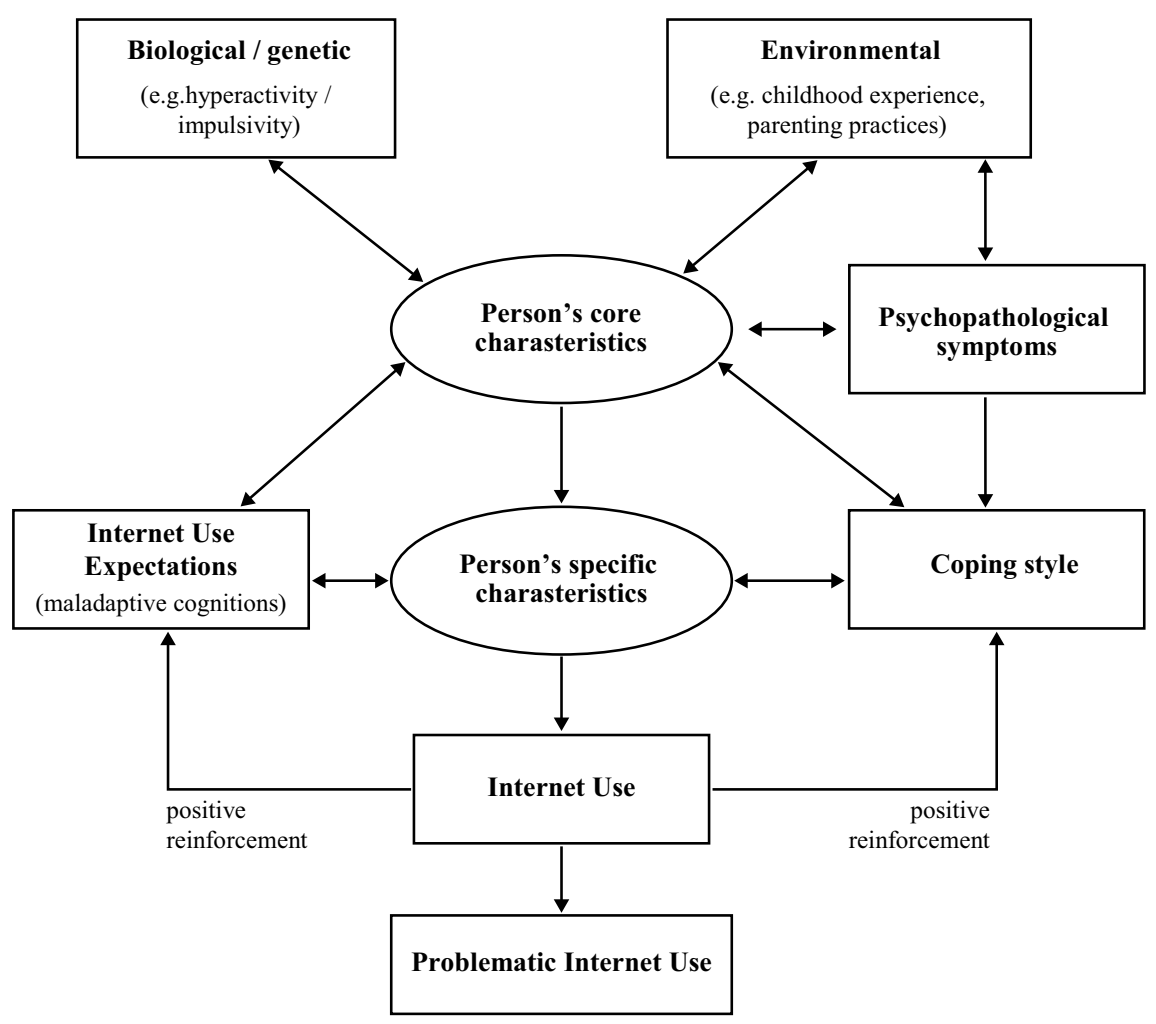

Figure 1. Theoretical model, based upon the models of Brand and colleagues (Brand, Young, \& Laier, 2014; Brand, et al., 2016) of interrelationships of biological, early environmental, psychopathological symptoms, coping style and maldaptive cognitions as facilitating Problematic Internet Use. The variable addressed int the present study are hyperactivity, parenting practices and maladaptive cognitions. 
Davis (2001), such as biopsychological vulnerability factors, including depression and anxiety disorders, as well as early childhood experiences and insecurity of attachment. The I-PACE model also incorporates internetrelated cognitive biases or maladaptive expectations which can promote internet addiction, as well as the coping styles by which a person attempts to deal with stressful situations. In addition, the I-PACE model includes neuropsychological mechanisms and executive control functions such as difficulties with inhibition and impulsivity as seen in attention-deficit/ hyperacitivity disorder (ADHD), one of the identified co-morbid conditions of internet-use disorders (Ho, et al., 2014). Brand and colleagues conclude with a call for additional research, specifically in investigating the interactions of these variables instead of studying them separately. Already Zhang, Li and Li (2015) have investigated several interactions of the above noted risk factors and found that maladaptive cognitions mediated the relation between temperament (e.g. effortful control and sensation seeking) and PIU, and that this relation was moderated by parenting styles.

Few studies to date have examined simultaneously biological, social and cognitive aspects as predictors of PIU. The present study is with the goal of examining the interrelationships between several potential risk factors of PIU, including possible "biopsychological contributions" (Brand, et al., 2016) such as hyperactivity and parenting practices, as well as internetrelated maladaptive cognitions. We hypothesize that adolescent reported hyperactivity, unsupportive parenting practices, as well as internet-related maladaptive cognitions will be predictive of PIU. We also hypothesize maladaptive cognitions to partially mediate the effect between parenting practices and PIU.

\section{Method}

\section{Participants}

Participants of the study were 307 adolescents (185 girls and 122 boys) aged between 13 to 19 years $(M=15.96$; $S D=2.45)$. The study participants were in attendance at middle school or high school, in classes from $7^{\text {th }}$ through $12^{\text {th }}$ grade. The participants were from various regions of Latvia, including both large and middle-sized cities. Schools were chosen according to accesibility. Adolescents reported their ethnicity as follows: $93.1 \%$ Latvian, $6.2 \%$ Russian, $0.7 \%$ other. Almost all of the study participants reported that computers and smart phones are readily available to them: $97 \%$ reported that they have a computer at home; $98 \%$ reported that they have internet access at home; 96\% reported that they have their own smart phone with internet access. 


\section{Procedure}

Permission was received from the school principals to conduct the study. Parents were informed, and passive consent was received, meaning that the parents were advised to indicate if they did not want their child to participate. Students were informed about the purpose of the study, principles of anonymity and voluntary participation. Active consent was received from all of the study participants. Questionnaires were distributed and collected by trained research assistants during homeroom class sessions.

\section{Measures}

All measures were forward and back-translated from English to Latvian and back by bilingual translators, with each translation performed independently. Consensus agreement was reached in regard to any discrepancies between the translations. The agreed upon translation was then pilot-tested and after initial psychometric analysis, including reliability and factor analysis, some items were relocated from one subscale to another. In some other cases the translation was made more precise in order to ensure conceptual equivalence of the items in comparison to the original. The questionnaire format was universally adapted to a 5-point Likert-type scale in order to facilitate the adolescents' familiarity and ease with the questionnaire format.

\section{Hyperactivity}

Hyperactivity was assessed with the hyperactivity subscale of the adolescent self-report form of the Strengths and Difficulties Questionnaire (SDQ; Goodman, 1997). The hyperactivity subscale has 5 items (e.g. "I am constantly fidgeting or squirming", and "I think before I do things", to be coded in reverse). The adolescents were asked to rate each item on a 5-point Likert-type scale from 0 ("never") to 4 ("always"). Cronbach's alpha rating for this scale was 71 in the present study.

\section{Parenting practices}

Parenting practices were assessed with several subscales from the Alabama Parenting Questionnaire (APQ; Frick, 1991; Shelton, Frick, \& Wootton, 1996): positive parenting, inconsistent discipline, and harsh punishment. The questionnaire completed by the adolescents included 11 items from the positive parenting subscale (e.g., "My parents have friendly talks with me"); seven items from the inconsistent discipline 
subscale (e.g., "My parents threaten to punish me but then actually do not punish me"); and four items concerning harsh punishment, adapted to their childhood experience (e.g., "When I was a child my parents spanked me when I had done something wrong"). All items were rated on a 5-point Likert-type scale from 0 ("never") to 4 ("always"). Cronbach's alpha ratings were from .67 to .84 in the present study.

\section{Maladaptive cognitions}

In this study the construct of maladaptive cognitions was considered as stemming from often unrealistic expectations or exagerated believs which favor the online world. In this study adolescents responded to 9 items, similar to those used by Li, et al. (2010), and Zhang, Li and Li (2015). Items such as "Friends online are more trustable than those offline" implies a negative cognition of others in the real world as untrustable, and the expectation that others who are online can be trusted. Items such as "When I am online I don't have do think about my problems related to school assignments" implies a distrust in one's own abilities to deal with one's school problems in a more adaptive way, such as completing one's assignments, but rather in dealing with school problems by escaping in the internet. The 9 maladaptive cognitions were rated on a 5-point Likerttype scale from 1 ("totally disagree") to 5 ("totally agree"). The Cronbach's alpha was .81 for the present sample.

\section{Problematic internet use}

The Problematic Internet Use scale was developed specifically for this study, based upon the Compulsive Internet Use Scale (Meerkerk, et al., 2009). This brief self-report measure included 4 items involving diagnostic criteria for problematic internet use: preoccupation with using the internet; need to use increased amounts of time; restless, moody or depressed when not using the internet; using the internet as way of escaping from problems. Items were rated on a 5-point scale, ranging from 1 ("never") to 5 ("always"). Cronbach's alpha was .78 for the present sample.

\section{Family economic status}

The adolescent's perception of family economic status was measured by asking the adolescent to mark one of the following: "my family can afford all that we want"; "my family is fairly well off"; "we get along at an average level"; "my family can afford only basic necessities"; "we are lacking even in the basic necessities". 


\section{Data Analysis}

Statistical analyses were conducted using SPSS version 22. First, zeroorder correlation coefficients were calculated to examine bivariate associations among the ratings of hyperactivity, parenting practices, maladaptive cognitions and PIU. Second, regression analyses were conducted, controlling for age, gender and family economic situation entered in the first step, in order to examine the predictive effects of hyperactivity, maladaptive cognitions, and which of the three measured parenting practices (positive parenting, harsh punishment and inconsistent discipline) would be shown to be significant predictors of PIU, when all four ratings were simultaneously entered in the second step. Third, the significant independent variables from the above regression analyses were entered into a combined regression model, again with age, gender and economic status entered in the first step. Fourth, the possibility of a mediation effect, as seen in the combined regression model was tested with an additional series of four regression analyses, all of which included the control variables age, gender and family economic status: PIU was regressed on maladaptive cognitions and inconsistent parenting; maladaptive cognitions were regressed on inconsistent parenting: and PIU was regressed on inconsistent parenting, accounting for the mediator maladaptive cognitions.

\section{Results}

Descriptive statistics and bivariate associations between the study variables are presented in Table 1. Problematic internet use was found to be positively correlated with hyperactivity, harsh parenting, inconsistent parenting, as well as maladaptive cognitions. Maladaptive cognitions were negatively correlated with positive parenting, but positively correlated with hyperactivity and inconsistent parenting.

When analyzing the two parenting practices (harsh discipline and inconsistent parenting) which had been shown to correlated positively with PIU, initial regression analysis showed inconsistent discipline to remain as the only significant predictor of PIU, when controlling for age, gender and family economic status, $\mathrm{F}(5,290)=5.450, p<.001$. The main regression model was computed in order to examine the combined effects of a biological factor (hyperactivity), social factor (inconsistent parenting) and cognitive factor (maladaptive cognitions), while controlling for age, gender and family economic status in the first step, in prediction of PIU. The results showed hyperactivity to be a significant contributing factor in the second step. In the third step both hyperactivity and inconsistent discipline were shown to be independent contributing factors to the variation in 
PIU ratings. However, with the addition of maladaptive cognitions ratings in the fourth step, there was a change in the Beta value of inconsistent discipline ratings (from $.20, p<.01$ to $.10, p=.079$ ), while hyperactivity and maladaptive cognitions were shown to be predictive of PIU ratings.

Table 1. Descriptive statistics and zero-order bivariante correlations between study variables

\begin{tabular}{lcccccc}
\hline & $\mathbf{1}$ & $\mathbf{2}$ & $\mathbf{3}$ & $\mathbf{4}$ & $\mathbf{5}$ & $\mathbf{6}$ \\
\hline 1. Problematic internet use & & $.31^{* * *}$ & -.06 & $.12^{*}$ & $.25^{* * *}$ & $.44^{* * *}$ \\
2. Hyperactivity & & & $-.26^{* * *}$ & .10 & $.29^{* * *}$ & $.19^{* *}$ \\
3. Positive parenting & & & & $-.26^{* * *}$ & $-.14^{*}$ & $-.12^{*}$ \\
4. Harsh punishment & & & & & $.29 * * *$ & .07 \\
5. Inconsistent parenting & & & & & & $.26^{* * *}$ \\
6. Maladaptive cognitions & & & & & & \\
Mean & 2.20 & 2.56 & 3.75 & 1.62 & 2.15 & 1.99 \\
SD & .79 & .68 & .80 & .77 & .71 & .71 \\
\hline
\end{tabular}

$* p<.05, * * p<.01, * * * p<.001$

Table 2. Hierarchical regression analyses including age, gender, material well-being, hyperactivity, inconsistent discipline and maladaptive cognitions predicting Problematic Internet Use $(N=305)$

\begin{tabular}{lcccccc}
\hline Predictor variable & & $\boldsymbol{B}$ & $\boldsymbol{S E}$ & $\boldsymbol{\beta}$ & $\boldsymbol{p}$ & $\boldsymbol{R}^{2}$ \\
\hline Step 1 & & & & & & .01 \\
& Age & -.02 & .02 & -.05 & .44 & \\
& Gender & .06 & .10 & .03 & .56 & \\
\hline Step 2 & .12 & .07 & .10 & .09 & \\
& Material well-being & & & & & .10 \\
& Age & -.02 & .02 & -.06 & .33 & \\
& Gender & -.03 & .09 & -.02 & .78 & \\
& Material well-being & .13 & .07 & .11 & .06 & \\
Step 3 & .35 & .07 & $.30 * * *$ & .00 & \\
& Hyperactivity & & & & & .14 \\
& Age & -.02 & .09 & -.06 & .27 & \\
& Gender & -.06 & .09 & -.04 & .49 & \\
& Material well-being & .10 & .07 & .08 & .13 & \\
& Hyperactivity & .28 & .07 & $.24 * * *$ & .00 & \\
& Inconsistent discipline & .26 & .08 & $.20 * *$ & .00 & \\
\hline
\end{tabular}




\begin{tabular}{lccccc}
\hline Predictor variable & $\boldsymbol{B}$ & $\boldsymbol{S E}$ & $\boldsymbol{\beta}$ & $\boldsymbol{p}$ & $\boldsymbol{R}^{2}$ \\
\hline Step 4 & & & & & .26 \\
Age & .01 & .02 & .02 & .69 & \\
Gender & -.08 & .08 & -.05 & .32 & \\
Material well-being & .08 & .06 & .07 & .20 & \\
Hyperactivity & .24 & .06 & $.21 * * *$ & .00 & \\
Inconsistent discipline & .13 & .07 & .10 & .08 & \\
Maladaptive cognitions & .42 & .06 & $.38 * * *$ & .00 & \\
\hline
\end{tabular}

$* * p<.01 ; * * * p<.001 ; \mathrm{F}(6,289)=16.509, p<.001$.

A final examination of mediation affects showed there to be a partial mediation effect of maladaptive cognitions between inconsistent parenting and PIU (see Table 3). Again all regressions were calculated controlling for age, gender and family economic status in the first step. Results showed a significant direct relation between inconsistent parenting and PIU $(\beta=.28$, $S E=.07)$, and a significant direct relation between maladaptive cognitions and PIU $(\beta=.44, S E=.06)$. After controlling for maladaptive cognitions, inconsistent parenting still significantly predicted PIU $(\beta=.16, S E=.07)$. The application of the Sobel test to the mediation effect showed that a statistically significant change occurs upon the introduction of maladaptive cognitions into the mediation model $(z=2.75 ; p<.01)$. Nevertheless, inconsistent parenting ratings maintain prognostic value, which indicates a partial meditational role of maladaptive cognitions between inconsistent parenting and PIU ratings.

Table 3. Maladaptive Cognitions mediating the association between Inconsistent Parenting and Problematic Internet Use (PIU) $(n=307)$

\begin{tabular}{|c|c|c|c|c|c|}
\hline & $\boldsymbol{B}$ & $S D(B)$ & $\beta$ & $\boldsymbol{F}$ & $R^{2}$ \\
\hline 1. Inconsistent parenting $\rightarrow$ & & & & $12.11 * * *$ & .14 \\
\hline Maladaptive cognitions & .32 & .06 & $.29 * * *$ & & \\
\hline 2. Maladaptive cognitions $\rightarrow$ & & & & $17.80 * * *$ & .20 \\
\hline PIU & .50 & .06 & $.44 * * *$ & & \\
\hline 3. Inconsistent parenting $\rightarrow$ & & & & $6.833 * * *$ & .09 \\
\hline PIU & .36 & .07 & $.28 * * *$ & & \\
\hline 4. Predicting PIU & & & & $16.214 * * * *$ & .22 \\
\hline Inconsistent parenting & .20 & .07 & $.16 * *$ & & \\
\hline Maladaptive cognitions & .44 & .06 & $.39 * * *$ & & \\
\hline
\end{tabular}

$* * p<0,01 ; * * * p<0,001$. Note: included in the first step of each regression was age, gender and family economic situation. Sobel test confirmation of the partial mediation effect, $z=2.75 ; p<.01$. 


\section{Discussion}

The aim of this study was to examine the interrelationships of adolescent problematic internet use (PIU) and specific biological, social (parental) and cognitive factors. The design of the present study was based upon the theoretical framework presented by Brand and colleagues (Brand, et al., 2016), who have proposed the Interaction of Person-AffectCognition-Execution (I-PACE) model. This model is multi-faceted, including a vast number of interacting variables, and the present study was not with the intention of exploring all of the variables proposed in the I-PACE model. Rather, this study was with the intent of focusing upon three specific risk factors - hyperactivity ratings as an indication of biological/ genetic vulnerabilities; adolescent-rated parenting practices as reflecting the immediate social, familial environment in whch the adolescent is developing; and maldaptive cognitions, as proposed by Davis (2001) to be facilitating factors of problematic internet use.

The initial correlational analysis showed that hyperactivity ratings and maladaptive cognition ratings were positively and directly correlated with PIU. Also positively correlated with PIU were inconsistent parenting and harsh parenting practices. The final regression model, explaining $26 \%$ of the variance of PIU ratings showed the following to be significant predictors: hyperactivity and maladaptive cognitions. Maladaptive cognition ratings were shown to have a partial mediation effect on the association between inconsistent parenting and PIU ratings.

The positive association between hyperactivity and PIU ratings is consistent with that found in previous studies and supported by several meta-analyses investigating this relation (Carli, 2013; Wang, et al., 2017). One of the most prominent aspects of ADHD is a tendency to react impulsively, with difficulty in controlling one's behavioral and emotional reactions. This difficulty in self-control can help to explain why the adolescent with hyperactivity symptoms may have difficulty in self-imposing time limits in regard to internet use - and, as is known, an accelerated amount of time spent on the internet is facilitative of internet addiction. The "aversion for delayed rewards" which is characteristic of individuals with hyperactivity, may facilitate internet addiction because the internet does provide immediate rewards in the form of game points and other bonuses. Certainly, the immediacy of reward (whether in winning points in a game or making new online friends) available in the internet often far surpasses that which one encounters in real life.

Parental inconsistent discipline was found to be predictive of internet dependency, both directly and also as partially mediated by maladaptive cognition ratings. Inconsistent discipline indicates that parents may 
erratically fluctuate on whether or not to follow-through on certain threatened punishments, depending upon the parents' mood or the child's powers of persuasion. This implies that although the parent may be attempting to limit the adolescent's internet use, their efforts are inconsistent and thereby likely to be unsuccessful, and that inconsistent parenting can facilitate the development of maladaptive cognitions (Halgunseth, et al., 2013). In addition, a parent who is inconsistent in disciplining their child may also be inconsistent in providing emotional support and understanding, which would then implicate insecure parent-child attachment. It has been widely recognized from an attachment theory perspective (Bowlby, 1989; Scimmenti, et al., 2014) that insecure attachment relationships encourage the development of less adaptive cognitions of self and others - including a distrust of others. The results of the present study seem to support these theoretical propositions - faced with the social context of inconsistent parenting and insecure attachment, the adolescent has been more likely to develop a basic mistrust of others in his immediate environment, and therefore more likely to develop maladaptive cognitions such as "friends online are more trustable than those offline".

\section{Limitations and Future Direction}

Among the limitations of the present study is its cross-sectional nature. It would be meaningful to look at the interrelationships between the biological, emotional, cognitive and behavioral aspects of problematic internet use within a longitudinal study design, so as to examine possible unidirectional and bidirectional effects. Another possible limitation is that all ratings were self-reported by the adolescents. Although it has been variously argued that the adolescents' own perception of the behavior of him or herself and others within the near environment is more important than the perceptions of others (Jessor, et al., 2003), nevertheless the possibility of utilizing multiple sources in order to access ratings of behavior (e.g. particularly in regard to hyperactivity and parenting practices) would be of added benefit. Reliance solely upon the adolescents' reports may have inflated the correlations due to shared method variance.

Practical implications. The present study points to the value of considering the possible interrelationships of various risk-factors for PIU, and, subsequently, the value of considering preventive measures addressing these various aspects, and a combination of assessment measures and treatment methods when providing rehabilitation for adolescents suffering from internet addiction. When considering treatment for PIU, then it is important to consider various therapeutic techniques - for example, behavioral techniques in regard to minimizing hyperactivity symptoms, 
psychoeducational approaches with the parents in order to help them to understand the importance of emotional support and consistent structuring, and cognitive-behavioral approaches to address and restructure the adolescent's maladaptive cognitions.

\section{Conclusion}

Few studies to date have examined simultaneously biological, social and cognitive aspects as predictors of PIU. This study investigated hyperactivity, parenting practices and maladaptive cognitions, as examples of biological, social and cognitive processes which may pose as risk factors for the development of PIU. It was found that after controlling for age, gender and family economic status, regression analysis showed hyperactivity, inconsistent parenting and maladaptive cognitions to be predictive of PIU. Maladaptive cognitions were shown to partially mediate the effect between insonsistent parenting and PIU. The practical implications of our study include the necessity of considerting various preventive and treatment approaches for adolescents who are at risk of problematic internet use which hinders adaptive functioning in their daily academic and personal lives.

\section{References}

Anderson, C. A., Suzuki, K., Swing, E. L., Groves, C. L., Gentile, D. A., Prot, A., Lam, C. P., Sakamoto, A., Horiuchi, Y., Krahé, B., Jelic, M., Liuqing, W., Toma, R., Warburton, W. A., Zhang, X.-M., Tajima, S., Qing, F., \& Petrescu, P. (2017). Media violence and other aggression risk factors in seven nations. Personality and Social Psychology Bulletin, 43(7), 986-998.

Balan, R., Dobrean, A., Roman, G. D., \& Balazsi, R. (2017). Indirect effects of parenting practices on internalizing problems among adolescents: The role of expressive suppression. Journal of Child and Family Studies, 26, 40-47.

Bowlby, J. (1988). A Secure Base: Parent-Child Attachment and Healthy Human Development. Tavistock professional book. London: Routledge.

Brand, M., Young, K. S., \& Laier, C. (2014). Prefrontal control and internet addiction: atheoretical model and review of neuropsychological and neuroimagingfindings. Frontiers of Human Neuroscience, 8(375), 1-13.

Brand, M., Young, K. S., Laiera, C., Wölfling, K., \& Potenza, M. N. (2016). Integrating psychological and neurobiological considerations regarding the development and maintenance of specific Internet-use disorders: An Interaction of Person-Affect-CognitionExecution (I-PACE) model. Neuroscience and Biobehavioral Reviews, 71, 252-266.

Carli, V., Durkee, T., Wasserman, D., Hadlaczky, G., Despalins, R., Kramarz, E., Wasserman, C., Sarchiapone, M., Hoven, C. W., Brunner, R., et al. (2013). The association between pathological internet use and comorbid psychopathology: a systematic review. Psychopathology, 46(1), 1-13. 
Chen, Y. L., Chen, S. H., \& Gau, S. F. S. (2015). ADHD and autistic traits, family function, parenting style, and social adjustment for internet addiction among children and adolescents in Taiwan: A longitudinal study. Research in Developmental Disabilities, $39,20-31$.

Ciarrochi, J., Parker, P., Sahdra, B., Marshall, S., Jackson, C., Gloster, A. T., \& Heaven, P. (2016). The Development of compulsive internet use and mental health: A four-year study of adolescence, Developmental Psychology, 52(2), 272-283.

Davis, R. A. (2001). A cognitive-behavioral model of pathological internet use. Computers in Human Behavior, 17, 187-195.

Dong, G., Shen, Y., Huang, J., \& Du, X. (2013). Impaired error-monitoring function inpeople with internet addiction disorder: an event-related fMRI study. European Addiciton Research, 19, 269-275.

Ehlers, A., \& Clark, D. M. (2000). A cognitive model of posttraumatic stress disorder. Behavior Research and Therapy, 38, 319-345.

Eijnden, R. J. J. M. van den, Spijkerman, R., Vermulst, A. A., van Rooij, T. J., \& Engels, R. C. (2010). Compulsive internet use among adolescents: Bidirectional parentchild relationships. Journal of Abnormal Child Psychology, 38, 77-89.

Frick, P. J. (1991). The Alabama Parenting Questionnaire. Unpublished rating scale. University of Alabama.

Goodman, R. (1997). The Strengths and Difficulties Questionnaire: A research note. Journal of Child Psychology and Psychiatry, 38, 581-586.

Halgunseth, L. C., Perkins, D. F., Lippold, M. A., \& Nix, R. L. (2013). Delinquentoriented attitudes mediate the relation between parental inconsistent discipline and early adolescent behavior. Journal of Family Psychology, 27(2), 293-302.

Ho, R. C., Zhang, M. W. B., Tsang, T. Y., Toh, A. H., Pan, F., Lu, Y., \& Mak, K.-K. (2014). The association between internet addiction and psychiatric co-morbidity: A meta-analysis. BMC Psychiatr, 14, 183. Retrieved from http://dx.doi.org/10.1186/1471-244X-14-183.

Jessor, R.,Turbin, M. S., Costa, F. M., Dong, Q., Zhang, H. \& Wang, C. (2003). Adolescent Problem Behavior in China and the United States: A Cross-National Study of Psychosocial Protective Factors. Journal of Research on Adolescence, 13(3), 329-360.

Jusiene, R., Cesniene, I., \& Mordas, V. (2015). Problematic internet use and psychological well-being in adolescence. $17^{\text {th }}$ European Conference on Developmental Psychology. Braga, Portugal.

Kaess, M., Durkee, T., Brunner, R., Carli, V., Parzer, P., Wasserman, C., et al. (2014). Pathological internet use among European adolescents: Psychopathology and selfdestructive behaviours. European Child \& Adolescent Psychiatry, 23, 1093-1102.

Ko, C. H., Yen, J. Y., Yen, C. F., Lin, H. C., \& Yang, M. J. (2007). Factors predictive for incidence and remission of internet addiction in young adolescents: A prospective study. Cyberpsychology \& Behavior, 10, 545-551.

Li, D., Zhang, W., Li, X., Zhen, S., \& Wang, Y. (2010). Stressful life events and problematic internet use by adolescent females and males: A mediated moderation model. Computers in Human Behavior, 26, 1199-1207.

Meerkerk, G. J., Van Den Eijnden, R. J. J. M., Vermulst, A. A., \& Garretsen, H. F. L. (2009). The Compulsive Internet Use Scale (CIUS): Some psychometric properties. CyberPsychology \& Behavior, 12(1), 1-6. 
Miltuze, A., Bite, I., \& Sebre, S. (2012). Adolescent identity development, problematic internet use, computer game playing, dissociation, anxiety and sexual concerns. $15^{\text {th }}$ European Conference on Developmental Psychology, Proceedings, 251-257.

Nikolas, M. A., \& Burt, S. A. (2010). Genetic and environmental influences on and symptom dimensions of inattention and hyperactivity: A meta-analysis. Journal of Abnormal Psychology, 119(1), 1-17.

Park, S. K., Kim, J. Y., \& Cho, C. B. (2008). Prevalence of internet addiction and correlations with family factors among South Korean adolescents. Adolescence, 43(172), 895-909.

Pies, R. (2009). Should DSM-V designate "Internet addiction" a mental disorder? Psychiatry, 6, 31-37.

Schimmenti, A., Passanisi, A., Gervasi, A. M., Manzella, S., \& Famà, F. I. (2014). Insecure attachment attitudes in the onset of problematic internet use among late adolescents. Child Psychiatry and Human Development, 45, 588-595.

Sebre, S., Jusiene, R., Dapkevice, E., Skreitule-Pikse, I., \& Bieliauskaite, R. (2015). Parenting dimensions in relation to preschoolers' behavior problems in Latvia and Lithuania. International Journal of Behavioral Development, 39(5), 458-466.

Selfhout, M. H. W., Branje, S. J. T, Delsing, M., ter Bogt, T. F. M., \& Meeus, W. H. J. (2009). Different types of Internet use, depression, and social anxiety: The role of perceived friendship quality. Journal of Adolescence, 32(4), 819-833.

Shelton, K. K., Frick, P. J., \& Wootton, J. (1996). Assessment of parenting practices in families of elementary school-age children. Journal of Clinical Child Psychology, 25, 317-329.

Wang, B-Q., Yao, N-Q., Zhou, X., Liu, J., \& Lv, Z-T. (2017). The association between attention deficit/ hyperactivity disorder and internet addiction: a systematic review and metaanalysis. BMC Psychiatry, 17, 260. DOI 10.1186/s12888-017-1408-x.

Yen, J. Y., Yen, C. F., Chen, C. C., Chen, S. H., \& Ko, C. H. (2007). Family factors of internet addiction and substance use experience in Taiwanese adolescents. CyberPsychology \& Behavior, 10, 323-329.

Young, K. S. (1998). Internet addiction: The emergence of a new clinical disorder. CyberPsychology \& Behavior, 1, 237-244.

Zhang, H., Li, D., \& Li, X. (2015). Temperament and problematic internet use in adolescents: A moderated mediation model of maladaptive cognition and parenting styles. Journal of Child and Family Studies, 24, 1886-1897.

Zhou, Z., Yuan, G., \& Yao, J. (2012). Cognitive biases toward internet game-related pictures and executive deficits in individuals with an Internet game addiction. PLoS One, 7(11), e48961. Retrieved from http://dx.doi.org/10.1371/journal.pone.0048961. 


\title{
CURRICULUM DEVELOPMENT MODEL FOR THE LATVIAN LANGUAGE AND LATVIA STUDIES PROGRAM IN CHINA
}

\begin{abstract}
This article discusses the curriculum development model for the Latvian Language and Latvia Studies Program in China. Based on the existing models of language curriculum development, as well as the administrative and pedagogical practice in the Less Commonly Taught European Languages (LCTELS) programs at Beijing Foreign Studies University (BFSU), this article aims to develop a curriculum model specific for the LCTELs programs in China. Document analysis, observation, questionnaire and semi-structured interview are used to reach the set target. This article examines language curricular models, and describes the outcomes of the LCTELs programs practice both in administrative and pedagogical procedures that aim to create a curriculum development model for the Latvian Language and Latvia Studies Program and expectantly, also for other new initial language programs in China's context, in order to get prepared for student enrolment in bachelor's level.
\end{abstract}

Keywords: China's context, language curriculum models, the Latvian Language and Latvia Studies Program.

\author{
ABBREVIATIONS: \\ BFSU - Beijing Foreign Studies University \\ CEFR - Common European Framework of Reference for Languages \\ $\mathrm{EFL}$ - English as a Foreign Language \\ ESL - English as a Second Language \\ LCTELs - Less Commonly Taught European Languages \\ LCTLs - Less Commonly Taught Languages
}




\section{Introduction}

Depth of China-Europe relations is accompanied by the increasing interest and high demand in learning of different European languages, with particular emphasis on Less Commonly Taught European Languages (LCTELs), amongst which Latvian language also takes place.

The Latvian Language and Latvia Studies Program in China (Chinese: 拉脱维亚语专业; hereafter called the Latvian Program) was started in 2010 at Beijing Foreign Studies University (BFSU). So far the program mainly conducts elective courses for non-LCTELs students with the instruction of expatriate teacher from Latvia. However it is planned to recruit the first class of postgraduate students by 2020, when Chinese local teachers accomplish training in Latvia.

The Latvian Program belongs to the group of the LCTELs programs in administration. LCTELs group is a branch of Less Commonly Taught Languages (LCTLs) from a geographical aspect. LCTELs as foreign language teaching in China can be dated back to the 1950s at BFSU with the start of the Polish and Czech language programs. Nowadays BFSU is the main university engaged in the LCTELs programs and offers the widest range of language studies in China, comprising of 20 bachelor programs, 12 master programs, and 4 doctorate programs. The administrative and pedagogical practice of the LCTELs programs at BFSU, primarily at the bachelor level, is the basis of this article.

Curriculum is continuously the central issue in both LCTELs teaching and learning. With the changes in social context, based on environment and need analysis, the LCTELs curriculum has been discussed and improved. Especially since 2000s, the development progress of information and technology field, led to fundamental changes and unprecedented challenges in education. As a result, the curriculum was in frequent revise to meet the evaluation standards and the social demands in the $21^{\text {st }}$ century. In 2007, based on the Common European Framework of Reference for Languages (CEFR), the General Curriculum for Teaching in LCTELs Bachelor Programs was created by a team of LCTELs professors at BFSU. In the same year, BFSU issued the official curriculum of the LCTELs programs, and continuously modifies it every four or five years; this process is guided by latest theories in the field, and classroom and social feedback as well. Coupled with increased national attention - the National Undergraduate Education Evaluation in 2012, the initial of the project "National Quality Standards for Undergraduate Programs" and "Belt and Road" Initiative in 2013, numerous seminars and workshops for LCTELs instructors and curriculum design specialists quest for more effective model to train/teach LCTELs learners. The latest modification for 
the official curriculum of the LCTELs programs at BFSU was completed in 2016. The new curriculum accepted the feedback of graduates, who are now working in different fields; kept the two main parts in previous curriculum, classroom teaching and extracurricular practice; and introduced the "Discipline Directional Module", which is instructed in the target language, in order to prepare students specialised in popular fields.

Although curriculum is being updated, problems still exist: 1) Nowadays curriculum development theories and models are mainly rooted in ESL or EFL teaching and learning in western context, and they cannot be fully adopted for language teaching and learning in China's context; 2) LCTELs curriculum development mainly follows and copies curriculum models of English language program, and it does not fully reflect the features of LCTELs teaching and learning; 3) Most of the LCTELs programs implementers are empiricists, curriculum development theories and models are not fully employed; 4) In the process of curriculum development, attention is mainly paid to pedagogical issues rather than administrational affairs.

Based on the above considerations, this article defines "curriculum" as the total teaching and learning experience either in pedagogical or in administrational aspect, which is planned and guided by the LCTELs programs in China, whether it is carried out in groups or individually, inside or outside the classroom. Through document analyses, four influential language curriculum models are compared to offer a framework for further LCTELs curriculum development. Nation \& Macalister's Model is chosen as basis for this article (comparative analysis shows in Table 1). This model contains a more comprehensive review of factors in curriculum development process than the rest. It is a stratified structure, which shows the overall relations of the different components (see Figure 1). "Principles" are listed as an independent component, to emphasise the importance and guiding role of theories and researches in the developing process, which are easily avoided by the novice practitioners. It distinguishes "assessment" and "evaluation", which refer to measure students learning results and the quality of curriculum respectively. This distinction makes the whole model more concrete and less vague.

Wang (2009) claims that educators and scholars are called to engage in rigorous discussion to develop language specific examples and performance indicators to guide program development and decision making for LCTLs instructors. The main aim of this article is to compare the existing curriculum development models, to adjust the factors based on the practical context in China, and to develop a curriculum framework for the Latvian Program. This framework is a necessary preparation for syllabi and the undergraduate students' enrolment by 2020 . 
Table 1. A comparative analysis of four language curriculum development models (Comparison was developed by the author)

\begin{tabular}{|c|c|c|c|}
\hline $\begin{array}{l}\text { Nation \& } \\
\text { Macalister's } \\
\text { Model (2010) }\end{array}$ & Murdoch's Model (1989) & $\begin{array}{l}\text { Graves' Model } \\
(1996)\end{array}$ & $\begin{array}{l}\text { Richards' } \\
\text { Model (2001) }\end{array}$ \\
\hline $\begin{array}{l}\text { Environment } \\
\text { analysis }\end{array}$ & $\begin{array}{l}\text { Resource limitations that } \\
\text { affect classroom activity; } \\
\text { Socio-cultural factors and } \\
\text { learning habits of relevance } \\
\text { to English teaching; } \\
\text { Aspects of target culture } \\
\text { that will interest learners } \\
\text { and can be exploited in } \\
\text { materials }\end{array}$ & $\begin{array}{l}\text { Consideration } \\
\text { of resources and } \\
\text { constraints }\end{array}$ & $\begin{array}{l}\text { Situation } \\
\text { analysis }\end{array}$ \\
\hline \multirow[b]{2}{*}{ Needs analysis } & $\begin{array}{l}\text { Learners' age group, present } \\
\text { lifestyle and interests }\end{array}$ & \multirow[b]{2}{*}{$\begin{array}{l}\text { Needs } \\
\text { assessment }\end{array}$} & \multirow[b]{2}{*}{ Needs analysis } \\
\hline & $\begin{array}{l}\text { Learners' present level of } \\
\text { competence; } \\
\text { Reasons for studying } \\
\text { English and long-term } \\
\text { learning aims }\end{array}$ & & \\
\hline Principles & - & $\begin{array}{l}\text { Articulating } \\
\text { beliefs (revised } \\
\text { in 2000) }\end{array}$ & - \\
\hline Goals & Course objectives & $\begin{array}{l}\text { Determining } \\
\text { goals and } \\
\text { objectives }\end{array}$ & $\begin{array}{l}\text { Planning goals } \\
\text { and learning } \\
\text { outcomes }\end{array}$ \\
\hline \multirow[b]{2}{*}{$\begin{array}{l}\text { Content and } \\
\text { sequencing }\end{array}$} & \multirow{2}{*}{$\begin{array}{l}\text { Language and procedures to } \\
\text { be covered by the course; } \\
\text { Emphasis on particular } \\
\text { skills; } \\
\text { Themes for course materials } \\
\text { and texts: Choice of suitable } \\
\text { textbooks. }\end{array}$} & $\begin{array}{l}\text { Conceptualizing } \\
\text { content }\end{array}$ & \multirow{2}{*}{$\begin{array}{l}\text { Course planning } \\
\text { and syllabus } \\
\text { design; } \\
\text { Design of } \\
\text { instructional } \\
\text { materials. }\end{array}$} \\
\hline & & $\begin{array}{l}\text { Selecting and } \\
\text { developing } \\
\text { materials and } \\
\text { activities }\end{array}$ & \\
\hline $\begin{array}{l}\text { Format and } \\
\text { presentation }\end{array}$ & $\begin{array}{l}\text { Methodology to be used: } \\
\text { type and sequencing of } \\
\text { activities }\end{array}$ & $\begin{array}{l}\text { Organization } \\
\text { of content and } \\
\text { activities }\end{array}$ & $\begin{array}{l}\text { Providing } \\
\text { for effective } \\
\text { teaching }\end{array}$ \\
\hline $\begin{array}{l}\text { Monitoring and } \\
\text { assessment }\end{array}$ & - & \multirow[t]{2}{*}{ Evaluation } & \multirow{2}{*}{$\begin{array}{l}\text { Approaches to } \\
\text { evaluation }\end{array}$} \\
\hline Evaluation & - & & \\
\hline
\end{tabular}




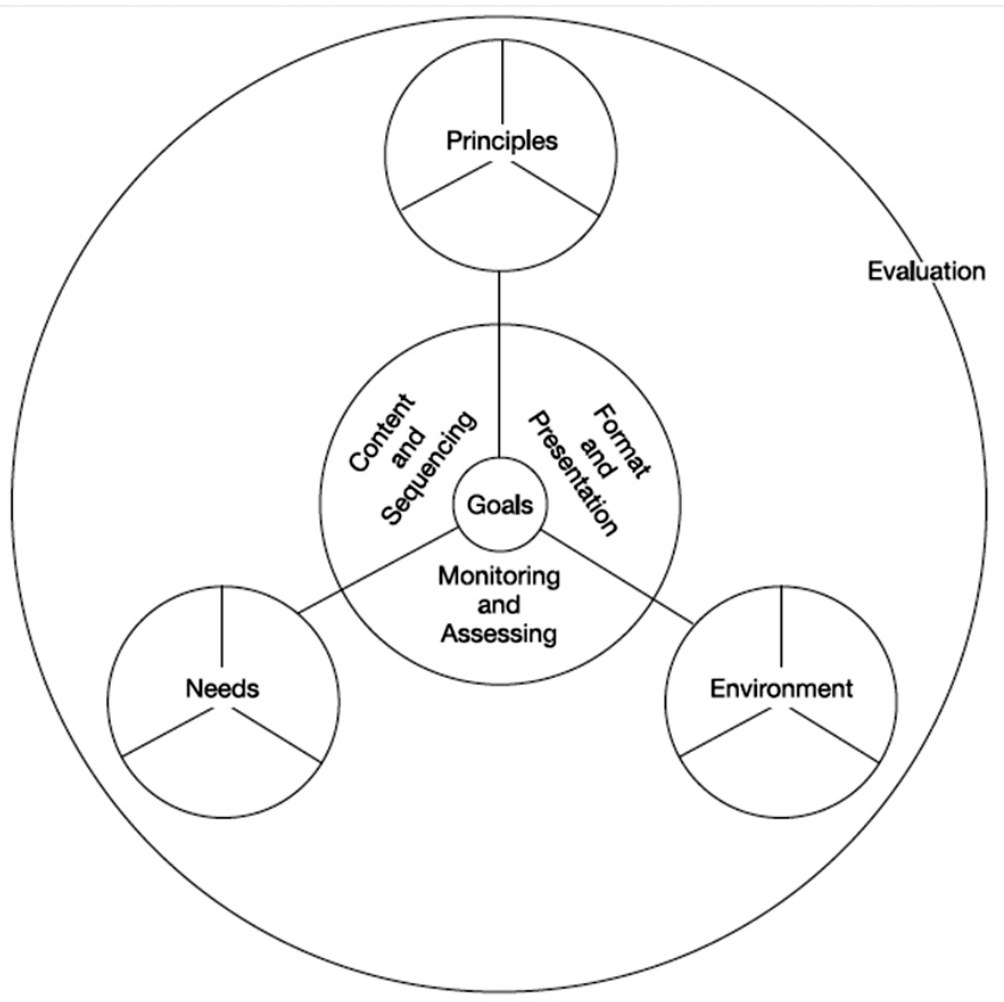

Figure 1. Nation \& Macalister's Model (Nation \& Macalister, 2010)

\section{Methods and Materials}

This article mainly uses the following methods: 1) Document analyses: reviewing the existing language curriculum development models, and the pedagogical/administrative documents in the LCTELs programs. 2) Observation: observing the pedagogical and administrative activities in the LCTELs programs. The full-time administrator of teaching affairs took charge of the whole observation process. Everyday's administrative work was recorded in worksheet. In each semester, 6 lectures in the different LCTELs programs were attended randomly. The observation period is from July, 2012 to December 2017, including 11 semesters. 3) Questionnaire on the theme of "motivation and motivating strategies", which was carried out in January, 2017. Questionnaire employed the Likert Scale with 5 degrees (Strongly agree $\rightarrow$ strongly disagree). Basic information and 36 multiple-choice questions were presented in two parts (Cronbach $\alpha$ were 0.754 and 0.920 respectively). The whole process was organized by e-mail and online questionnaire system, and involved 259 students 
and 31 teachers in 15 LCTELs programs. (Lu, 2018). 4) Semi-structured interviews on the theme of "the brief history of curriculum development in the LCTELs programs" with 51 teachers and administrative staff in the 23 LCTELs programs, which was carried out in July-August, 2017. 5 openended questions were raised to each participant, and snowball method was employed to obtain detailed information.

\section{Results and Discussions}

In this part, particular curriculum development considerations for the LCTELs programs, including the Latvian Program, were discussed in context of China.

\section{Component 1: Environment analysis}

The comprehensive discussion about environment/situation analysis is in Richards' model (Richards, 2001, 90-111); six layers are listed: societal, project, institutional, teacher, learner and adoption factors. For commonly taught languages, especially for English, the theories and researches are rather mature, the materials and resources are abundant, and the communication among different communities is quite frequent, thus societal factors in daily teaching generally are confined to own inner community. However, LCTLs are facing inadequate teacher education programs, the unavailability of pedagogically sound teaching materials and geographical and professional isolation (Brown, 2009; Johnston, Janus, 2003). In order to compensate these disadvantages, factors in wider range - the global context must be analysed. Global factors play a role mainly in two really wide aspects: 1) Target country/region governments and people. Policy and institutions for language promotion, teaching materials and resources, educational organisations, students exchange mechanism, and people's attitude are essential factors for the LCTELs programs; 2) The worldwide teaching situation of LCTELs. Regular communication and cooperation among the LCTELs programs in different countries can share experience and suggestions, and it is an effective way to break geographical isolation.

\section{Component 2: Needs analysis}

When it comes to "needs analysis" in different models, attention is unanimously paid to "learners' needs". This article also explores needs of other main stockholders in practice. 


\section{Learners' needs}

Unlike the direct exploration to learners' needs in the English learning, the analysis in the LCTELs programs is circuitous. Due to geographical distance, students have little knowledge about most of LCTELs and cultures when they enrol in the current programs and hardly express specific needs. Additionally higher education admission system in China cannot guarantee the students enrolled for their first or main interest. LCTELs programs admission requirements, to some extent, are lower than the commonly taught languages programs. If students in the National College Entrance Examination cannot achieve the requirements of the more popular programs, they might be accepted by the LCTELs programs in case if they want. In the questionnaire which was carried out in January, 2017, 62.1\% of respondents answered that the programs they enrolled are not their first choices. But the result does not mean that they are not interested or satisfied in future studies. In the same investigation, $80.5 \%$ and $80.2 \%$ of them showed interests in the target languages and cultures respectively. In the LCTELs programs, to certain degree, to quest the needs of learners is an overlapped process for teachers and administrators to motivate students to find their own needs. As observed, motivating can lead to three results: 1) Fully-motivated. Students are devoted to the LCTEL learning, and decide to pursue professions or further studies related to the language and culture. 2) Partly-motivated. Students can fulfil the assessments in the program, but their expectation of the program is more about completing higher education degree. 3) Non-motivated. Students show no interest in study, and cannot fulfil the assessments in the program.

As three situations may coexist in one program and it makes the curriculum management very complicated, effective administrative process should be considered to lower the contradiction and maximise the concordance. The main measure is to break the barriers between programs/ faculties/universities, to design sub-curriculum, as well as standards for delisting, to offer students more opportunities. The administrative process can be designed as showed in Figure 2.

As Spratt, Humphreys and Chan (2002) reported the case in Hong Kong that students expected their teachers to make all the pedagogical decisions instead of themselves, believing that to teach is the teachers' job. Students who enrol in the university are not always ready for next chapter of life and enjoy autonomy in university. Concluded from teachers' feedback and observation records, the causes are mainly two: (1) education in China's traditional context contains a history of compliance with teachers' 


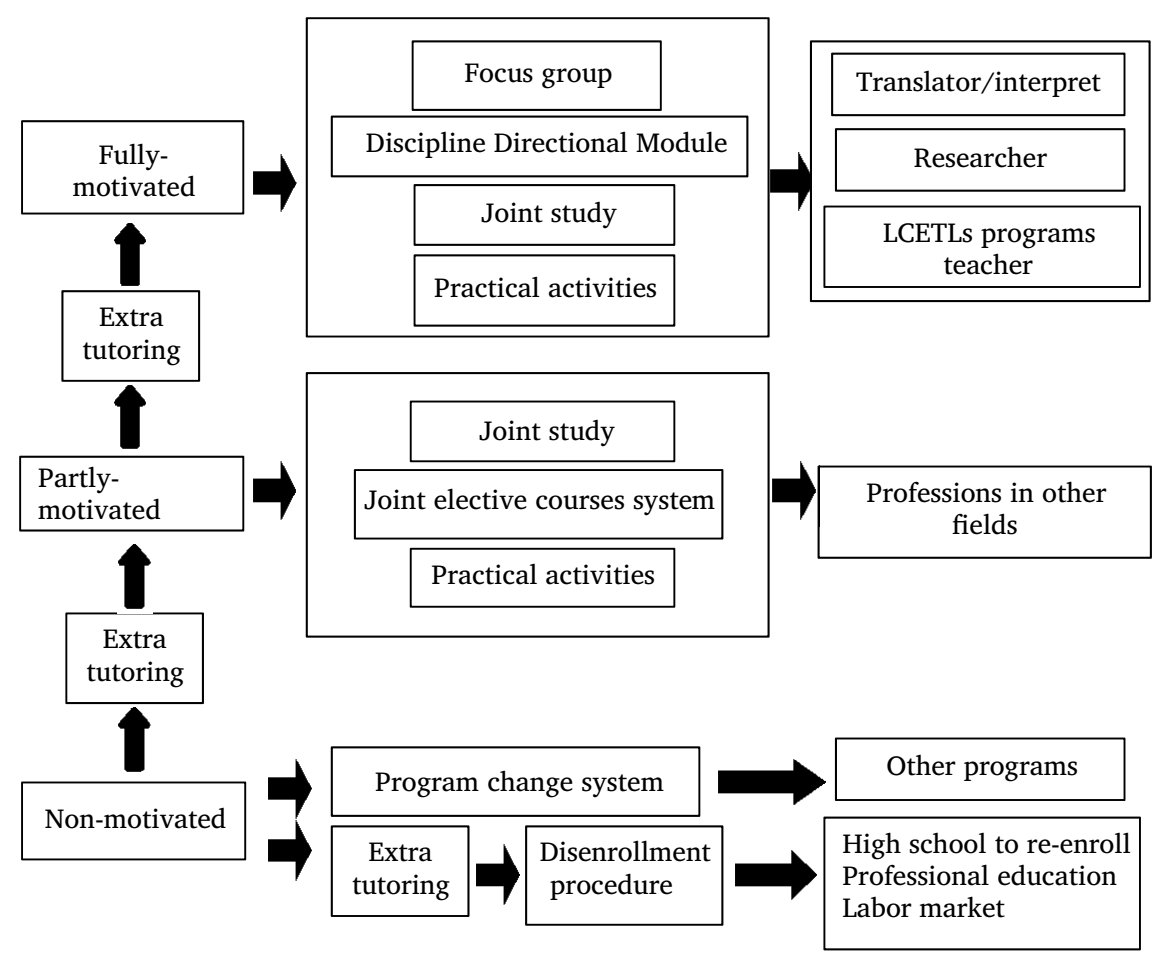

Figure 2. Administrative process in the three motivating situations

instruction; (2) after the National College Entrance Examination, many students feel relaxed from previous pressure and lose the willingness to study as hard as before. For the fully-motivated students, "focus groups" and "Discipline Directional Module" (which guides students to specialise in one social or humanities science sphere with the target language) are designed to deepen their interests and channel them to certain professions, mainly translator/interpreter, researcher and LCTELs teacher/administrator. For the partly-motivated students, while leading them to find their real interest in the "Discipline Directional Module", the curriculum encourages them to join "joint study program", such as LCTELs-Law, LCTELs-Economics programs. Students are encouraged to learn knowledge of another discipline sphere in Chinese or English, while they can succeed in the assessment of LCTEL proficiency. For the non-motivated students, program offers opportunity to be tested for another program in the university during the first academic year. Students, who neither qualify for other programs nor pass assessment in own program after certain amount of extra tutoring hours, will be persuaded to quit and try other possibilities. 


\section{Teachers' needs}

The observation in the teaching process and feedback in the interview show that all the LCTELs programs suffer a shortage of qualified instructors. Generally, the staff structure for one program is 1-3 local teachers and 1 expatriate teacher. LCTELs teachers have very heavy work load: they need to manage and design curriculum, to instruct all courses in different types, to collect and develop teaching materials, to maintain relationship with other stockholders and cooperation with institutions overseas, to care about students and to do research in related fields. Nowadays, in higher educational institutions, one important measurement to teachers is their research capability. And the teachers' continuous level of research will also decide the quality of courses in the "Discipline Directional Module". However, due to inadequate experience and resources, limited time and training programs, this task is much more challenging for LCTELs teachers. A win-win method is to organise research teams guided by specialists, to make interdependence of teaching and research, to collect the hot issues and to assign work according to teachers' individual interest. Therefore, to investigate teachers' research interest, which is also one of teachers' needs, is important for curriculum development. Even in the phase of teachers' recruitment, special attention should be paid to organise research team with teachers of different interest fields.

\section{Institutional needs}

Although many cases on cooperation between the LCTELs programs and the institutions in the target country/region have successfully been implemented, the incompatibility of the different systems and mismatch of needs and supplies remain amount of memorandums on papers. In order to improve the effectiveness of cooperation, the needs analysis of both sides is necessary. From the LCTELs programs' side, the main need is serious courses on language and culture to improve both teachers' and students' language proficiency and culture understanding in the authentic language environment. Scholarship provided to support students in the study by the target country government or educational institutions is also a favourable complementary. From the target country/region side, the needs might be such as: 1) Language and culture promotion abroad; 2) Building of international and intercultural relationships; 3) Increasing international students number leading to raise the place in world university rankings; 4) Exchanging students to study in China, preferably in the program of Chinese language and culture; 5) Sharing the teaching and research resources by exchange of scholars; 6) Gaining profit or financial support; etc. 
In practice, two dilemmas often emerge: 1) the language courses' levels or studying hours offered by the target institutions are not applicable to the students from the LCTELs programs; 2) the faculty which sends students to target country/region and the faculty which is expected to receive students from the target country/region is not the same one. To solve these problems requires further negotiation based on the need analysis.

\section{Component 3: Principles}

Most of the LCTELs instructors are specialised in their chosen language and literature studies, and have little or no background in foreign language teaching methodologies and curriculum design. During the semi-structured interview in July-August, 2017, responses showed that just 4 out of 51 respondents have received systematic training in foreign language acquisition and curriculum design during their master or doctorate studies. The LCTELs instructors have deeper understanding and practical experience in teaching and managing courses, and often follow intuition, not "principles" to make decisions. Practice and theory are disjointed in this situation.

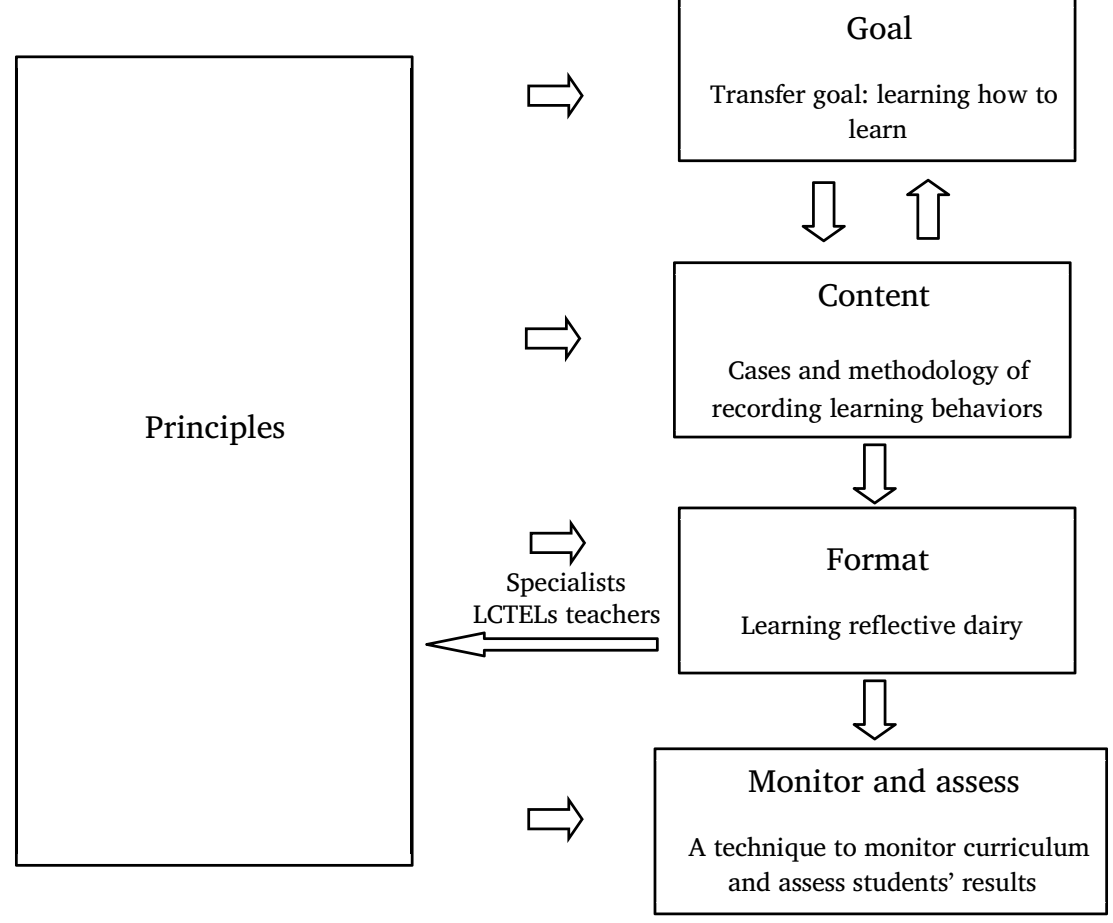

Figure 3. Students' participation in the factor "Principles" 
Increased national attention and the development of LCTLs programs lead researchers in foreign language acquisition and specialists in curriculum design to pay attention more actively to LCTLs. A cooperative mode gradually forms, which consists of such specialists and LCTLs teachers. In joint researches, specialists guide LCTLs teachers to analyse teaching materials with suitable theory and methodology. This mode breaks the boundary between institutions, achieves mutual benefits and gives positive results (Wen, 2016; Wen, Zhang, 2017; Dong, 2016).

Empirical research plays a very important role in investigating teachers' and learners' behaviours to produce "principles". However, it requires long-time and thorough accumulation in daily learning process. Two or three teachers can hardly fulfil such task. Current situation could be turned around with encouragement of students to participate in the active process. It is also a way to connect the factors of curriculum closer. This process can be designed as in Figure 3 .

\section{Component 4: Goals}

Stern (1992) proposed rather comprehensive and applicable classification of goals. He divided goals in the process of language learning into four categories: proficiency goals, cognitive goals, affective goals, and transfer goals. Proficiency goals include general competency, mastery of the four skills (speaking, listening, reading, and writing), or mastery of specific language behaviours. Cognitive goals include mastery of linguistic knowledge and mastery of cultural knowledge. Affective goals include achieving positive attitudes and feelings about the target language, achieving confidence as a user of the language, and achieving confidence in oneself as a learner. Transfer goals involve learning how to learn so that one can call upon learning skills gained in one situation to meet future learning challenges, (Graves, 1996, 17). Good psychological condition and adaptive learning methods are strong support to obtainment of knowledge and skills, thus the last two goals should be emphatically addressed. For students in the LCTELs programs, most of them received good results during their high school period, and their self-expectation is always quite high. LCTELs are relatively unfamiliar and difficult to Chinese learners. When students start new studies in university, they often suffer from uncertainty and stress in competition with other classmates; especially the ones, who had less practice in foreign language communication, in result they easily lose confidence in speaking publicly. When designing curriculum, the communicative approach is applied not only to improve language proficiency, but to achieve positive attitude and to gain techniques for maintaining personal and interpersonal development. 
Language is a tool for communication; however, it is not just a tool. It interrelates with amount of disciplines and offers countless possibilities of future career development. But in one program, it is impossible to exhaust all the possibilities for students. To teach them how to learn and how to plan for their career is more important than the particular skills and knowledge. In order to fulfil the "transfer goals", there is necessary to have, in the curriculum, courses or modules based on general theories and methodologies.

\section{Component 5: Content and sequencing}

One highlight in present LCTELs curriculum is the exchange studies in the target country/region during the $2^{\text {nd }}$ or $3^{\text {rd }}$ academic year. The content of curriculum in this year focuses on improvement of language proficiency and broadening understanding about culture itself. The aim of language proficiency is level B1-B2 in the $2^{\text {nd }}$ academic year or B2-C1 in the $3^{\text {rd }}$ academic year.

However, whether the aim can be achieved or not, mainly depends on the courses provided by the cooperative institutions in the target country/ region. For the Latvian Program, considering the present conditions, if no special fund is offered to customise courses, it is hard to achieve the above-mentioned aim. Currently, in the educational institutions in Latvia, exchange students have opportunity either to attend programs for local students instructed in Latvian, or to join programs for international students mainly instructed in English. If students enter the local students group, the lower language level might make them lag behind; while if they enter the international students group, the academic hours for Latvian language learning are not enough to succeed intended language level. Although in authentic language environment, communicating with local people might be a compensatory method, it is not a systematic way for learning foreign language, especially for adults. Besides, many students are not ready for such autonomous learning. 30 of 134 students in other LCTELs programs, who participated in the questionnaire carried in January, 2017, confirmed that they did not progress much during exchange study, due to their bad management of "free" time.

To revise the "content" or "sequencing" of the curriculum during exchange study can reduce the incompatibility.

\section{Component 6: Evaluation}

Evaluation in Nation \& Macalister's Model specifically refers to assessment of curriculum. Evaluation varies from different levels, mainly including 
national level, university level, faculty level and program level. The first two levels are implemented in a top-down way by curriculum specialists. They are authoritative and executive in the process, and are expected to provide more meaningful instructions for further development. But often in practice, lack of effective feedback system makes the end stay in form. Nowadays, Office Automation System is popularised in educational administration. To publish and share information in such a platform can offer stockholders opportunity to check the evaluation results as they wish. Summative discussion is also necessary to make sure that all staff is well informed.

Evaluation in faculty and program level on the whole is self-check and spontaneous, depending on teachers' schedule. It is often neglected when teachers have heavy workload. However, evaluation in these levels has greater help to teachers either in teaching practice or in research. LCTELs teachers know better the situations in LCTELs teaching. Evaluating each other is an efficient way to find advantages and disadvantages, to achieve self-reflection and to accumulate empirical materials. From faculty administration level, some compulsory measures can be taken to encourage these kinds of evaluation, such as to list it as part of teachers' assessment.

\section{Conclusion}

In recent researches curriculum development was mentioned as essential to enhancing instruction within LCTLs programs. Developing curriculum needs language curriculum development models, which aim at producing relevant, effective and efficient language teaching programs. However, at the present language curriculum development models are mainly rooted in ESL/EFL teaching and learning. Although they give curriculum practitioners good instruction, but still no single model of language curriculum development can claim to have satisfactorily resolved the question of how these criteria are best applied in every case. To achieve a relevant, effective and efficient curriculum development process, on one hand, adoption of the general language curriculum development theory and models are necessary; on the other hand, adaption according to different language teaching and learning features and contexts is also indispensable. Based on the comparison of the existing language curriculum development models, this article adopted Nation \& Macalister's Model as basis, adapted most of the components with considerations in other models and LCTELs teaching practice in China, broadens the discussion to more stockholders involved and explored an expanded model, which is more suitable to the forthcoming enrolment of the Latvian Program either in pedagogic or administrative aspect in China's context, expectedly also to other young LCTELs programs. All considerations in each component still need to be 
examined and revised in further practice, and detailed content of the curriculum will be the further research work.

\section{Acknowledgment}

The research was instructed by Prof. Ilze Kangro and supported by China Scholarship Council.

\section{References}

Brown, A. (2009). LCTL and CTL Students: A Demographic and Academic Comparison. Foreign Language Annals, 42(3), 405-423.

Diffey, N. (1992). Second-language Curriculum Models and Program Design: Recent Trends in North America. Canadian Journal of Education, 17(2), 208-219.

Dong, X. (2016). The Problems of Lesser-Used European Languages Education in China and Some Relevant Advice. Journal of Language Planning, (2), 68-75.

Graves, K. (1996). A Framework of Course Development Processes. In: Graves, K. (Eds.) Teachers as Course Developers (pp. 12-38). Cambridge: Cambridge University Press.

Graves, K. (2000). Designing Language Courses: A Guide for Teachers. Boston: Heinle and Heinle.

Graves, K. (2008). The Language Curriculum: A Social Contextual Perspective. Language Teaching, 41(2), 147-181.

Hutchinson, T., \& Waters, A. (1987). English for Specific Purposes. Cambridge: Cambridge University Press.

Janus, L. (2000). An Overview of Less Commonly Taught Language in the United States. MASSP Bulletin, 84, 25-29.

Johnston, B., \&Janus, L. (2003). Teacher professional development for the less commonly taught languages. Minneapolis, MN: Centre for Advanced Research on Language Acquisition.

Kelly, A. V. (2004). The Curriculum: Theory and Practice. London: SAGE Publications.

Kennedy, C. (1987). Innovating for A Change: Teacher Development and Innovation. ELT Journal, 41(3), 163-169.

Kerr, J. F. (1968). Changing the Curriculum. London: University of London Press.

Lee, Y. A. (2006). Towards Respecification of Communicative Competence: Condition of L2 Instruction or Its Objective. Applied Linguistics, 27(3), 349-376.

Lu, Y. (2018). Investigation of Learning Motivation and Motivating Strategies in Less Commonly Taught European Languages Teaching Context in China. LU Raksti. Izglitibas vadiba, 817, 72-82.

Marsh, C. J. (1997). Perspectives: Key Concepts for Understanding Curriculum. London: The Falmer Press.

Mills, N., Minuchehr, P. (2014). The Development of A National Curriculum Guide for Persian: Themes, Genres, Standards-based Goals, and Models. Journals of NCOLCTL, 16(2), 111-146. 
Murdoch, G. S. (1989). A Pragmatic Basis for Curriculum Design. English Teaching Forum, 27(1), 15-18.

Nation, I. S. P., Macalister, J. (2010). Language Curriculum Design. New York: Routledge.

Nunan, D. (1985). Language Teaching Course Design: Trends and Issues. Adelaide, Australia: National Curriculum Resource Centre.

Nunan, D. (1987). The Teacher as Curriculum Developer. Sydney: National Curriculum Resource Centre, Adult Migrant Education Program.

Richards, J. C. (1985). Language curriculum development. Retrieved from https://scholarspace.manoa.hawaii.edu/bitstream/10125/38633/1/Richards\%20(1985)_WP4(1).pdf

Richards, J. C. (2001). Curriculum Development in Language Teaching. Cambridge: Cambridge University Press.

Richards, J. C. (2013). Curriculum Approaches in Language Teaching: Forward, Central, and Backward Design. RELC Journal, 44(1), 5-33.

Sprrat, M., Humphreys, G., Chan, V. (2002). Autonomy and Motivation: Which Comes First? Language Teaching Research, 6(3), 245-266.

Stern, H. H. (1992). Issues and Options in Language Teaching. Oxford: Oxford University Press.

Tarone, E. (2015). Second Language Acquisition in Applied Linguistics: 1925-2015 and Beyond. Applied Linguistics, 36(4), 444-453.

Wang, S. (2009). Preparing and Supporting Teachers of Less Commonly Taught Languages. Modern Language Journal, 93(2), 282-287.

Wen, Q. (2016). Producing Language-qualified Personnel for "the Belt and Road Initiatives". Chinese Journal of Language Policy and Planning, 2, 20-25.

Wen, Q., Zhang, H. (2017). Career Development of University Teachers of LessCommonly-Taught Foreign Languages: Challenges and Dilemmas, Foreign Languages in China, 6, 96-100.

Yilmaz, F. (2011). Evaluating the Turkish Language Curriculum at Jagiellonian University in Poland: A Case Study. Život i škola, 25(1), 76-90.

Zhong, W. (2015). The Innovative Development of English Majors under the Direction of National Standards of Teaching Quality for Undergraduate English Majors. Foreign Language World, 3, 2-8. 


\title{
TEACHER EDUCATORS AS PARTICIPANTS OF INTERNATIONAL PROJECTS: EXPERIENCE, CHALLENGES AND OPPORTUNITIES FOR THE DEVELOPMENT OF TEACHER EDUCATION
}

\begin{abstract}
Internationalisation is an integral part of the overall mission and strategy of higher education institutions. National, international and even global cooperativeness and partnerships have become indispensable components of teacher education institutions. The paper discusses the rationale for teacher educators' participation in international projects and reflects on the gains and lessons learnt from the participation in three multilateral projects. Findings suggest that any participation in partnerships should provide considerable benefits not only for the actively involved teacher educators and students, but also home institution, its departments, other colleagues and students who did not participate in the international project. More teacher educators and students gain experience abroad, broadening their understanding of the contemporary teacher education, more world and open-minded the faculty and student teachers become thanks to various project dissemination and follow-up events.
\end{abstract}

Keywords: collaboration, internationalisation, partnership, project, teacher education.

\section{Introduction}

Increasing interconnectivities, interdependencies, cultural interactions, moreover, competitiveness characterise the contemporary world (Cohen \& Kennedy, 2013), where the globalisation has led to "exposure to and contact with" (Greene, 2009, p. 328) differences on a greater scale, and cooperation is not always easy. Nevertheless, interaction, collaboration and partnerships with other like-minded institutions of the same or 
similar discipline is common in higher education. In other words, global cooperativeness, global competitiveness and internationalisation have entered the core aims of the university strategy and development.

Although Duffield, Olson and Kerzman (2013) consider that higher education institutions are not designed for collaboration with one another as they have their own individual mission, unique and recognisable identities, the necessity for collaboration and partnership building underlies the modernisation and internationalisation strategies. Changing student demographics, contemporary demands in the labour market for teachers, challenges that have resulted from the impact of economy, technology, politics and even business require the cooperation of teacher educators to become more aware of the concerns and search for multilateral solutions (Blūma, 2016). Husso, Korpinen and Asunta (2006) see that "networking and equal cooperation-partnerships are important starting points to create a new definition of teachers' professionalism with teachers' work changing from action alone to action together" (p. 116). Hence, this paper discusses the rationale for teacher educators' participation and collaboration in international projects.

When examining the collaboration of teacher education institutions in practice, first, it should be stated that it is a fundamental and strategic necessity to collaborate across departments and faculties within an institution to develop and realise qualitative teacher education programmes and interdisciplinary teaching opportunities. Second, it is essential to maintain an active collaboration with schools at all levels of education, other universities and higher education institutions, public, scientific, social and business organisations, NGOs, government, municipalities, and even media. Third, a collaboration with international partners, realising similar teacher education programmes, adds the international dimension to the goals of the institution. This means the international dimensions of curricula, a positive and efficient approach to foreign language learning, staff and student incoming and outgoing mobility, international partnerships to acquire research funding and complete collaborative teaching or research projects, networking, associations and consortia. Besides, with reference to European Commission (2013), an explicit internationalisation strategy must be an integral part of the overall mission and strategy of the individual higher education institution.

In this context the identity of teacher educators can be reviewed. Boyer (1990) reminds that teaching was the primary role of academics, historically; however, currently, their roles become increasingly complex (Blackmore \& Blackwell, 2003). Klecka, Donovan, Venditti and Short's (2008) research identified five facets of the identity of teacher educators: teacher, scholar in teaching, collaborator, learner and leader. Indeed, key 
responsibilities of teacher educators are multifaceted, covering such areas as teaching, consultancy, management, community of practice engagement, research and professional development (Boyer, 1990; Augstskolu likums, 1995-2018; Blackmore \& Blackwell, 2003; Higgs \& McCarthy, 2008; Blūma, 2016).

Besides, Eddy and Garza Mitchell's (2012) research shows that "changes in faculty work have led to an increased need for faculty members to garner research funding and other support in addition to regular teaching, service, and research duties" (p. 284). This is relevant to many higher education institutions; academic staff is invited to involve and generate more income from externally paid projects. Apparently, it is a pragmatic concern to excel in research, improve the attractiveness and obtain efficient enrolment rates in study programmes.

Looking from the dean's position, Jarchow (1997) states the necessity to establish and participate in international projects as the institution and its faculty can benefit considerably. First, teacher educators can take advantage of opportunities to keep up with those international changes that affect their discipline, develop their global competence, collaborating with multicultural teacher educators, meanwhile, think globally but act locally within their institution and community. Second, the institution's openness to international perspectives provides a better study experience for students: a global climate due to faculty exchanges, visiting scholars, incoming international students as a local resource to offer opportunity to learn more about the world, giving seminars on educational issues in their home countries; student study tours and summer schools where students can gain from hands-on activities with international participants. Third, Jarchow (1997) sees a benefit from joining organisations and consortia that focus on activities which can enhance the further development of the teacher education quality. Knowledge sharing, collaboration to excel in research, teaching and curriculum development, exchange of academic staff and students, cooperation between higher education, government and other sectors to develop a worldwide network of resources for innovative teacher education programmes are just few of activity examples.

Projects that cross borders can offer unique opportunities (Freedman \& Katz, 2007), when the gained international experience is valued, encouraged and supported (Eddy \& Garza Mitchell, 2012; Duffield, Olson, \& Kerzman, 2013) in the teacher education institution. Joining international initiatives, organisations and consortia related to higher education and pedagogy is worth endeavours to broaden the understanding of the contemporary teacher education, advance knowledge within disciplines of education, explore best practices and, as a result of collaborative projects, introduce and disseminate intellectual outputs, innovations and services 
that were not possible without the partnership. Creamer (2004) reveals that collaboration, especially if it is long-term, can move faculty members beyond individualistic thinking to global perspectives that challenge their preconceived notions of knowledge. Thus, collaborators are able to accomplish more together than they would have on their own, meanwhile, with reference to Heffernan and Poole (2005), providing a competitive advantage to an institution.

However, Eddy and Garza Mitchell (2012) consider the danger of an increased academic workload that could lead to dissatisfaction with one's faculty role and a lag in productivity. It cannot be denied that an active participation in any project requires additional time and increased workload to carry out project activities, make valuable contribution, attend meetings, moreover, be away from the home institution for some time.

As a teacher educator herself, the author can admit the considerable tension she senses between the teaching, research and project related opportunities and activities; each of them is time consuming, still crucial for the professional development. A clear definition of project goals and objectives can help to decide upon agreeing to join and contribute with one's endeavours and time. Besides, strong motivation, international interests and expertise in specific academic disciplines, openness, communication, trust and relationship commitment, identified long-term benefits of experience and loyalty to the home institution are aspects that can support teacher educators' decision to participate in international projects.

\section{Methods and Materials}

To explore the rationale for teacher educators' participation in international partnerships, this study presents an overview of theoretical underpinnings for collaboration in teacher education and uses a case study methodology, characterized as being particularistic, descriptive, heuristic in nature and with specific time boundaries (Merriam, 1998). The author introduces three cases of multilateral projects, she had the opportunity to be involved, and reflects on the gains and lessons learnt from the participation in them. The project analysis is done on the basis of project documents and evaluation reports, meeting minutes, project partners' and students' questionnaire results and the participant's observations during the project realization process.

Considering the teacher education institution's internationalisation efforts, the projects were selected according to the following criteria: the project had to be international; the teacher educators had opportunities for collaborative research and joint activities, furthermore, improving their professional skills and global competence; the teacher educators' 
professional development experience, gained during the international project, became a part of the prospective teachers' learning opportunity and development at the university. Thus, these three international projects contributed towards the professional development of a relatively large group of participants, i.e. faculty, international partners, above all, local and international students.

\section{Results and Discussions}

Case 1. To initiate a cooperation partnership for innovation and exchange of good practice a multilateral two-year project (2014-2016; ERASMUS + "Open the Door to Europe" Project No. 2014-1-ES01-KA204-004738) was carried out by six partners, representing universities, institutes and competence centres for adult education from Bulgaria, Germany, Italy, Latvia, Poland, Spain and Turkey. The aim of the partnership was to exchange experience and knowledge of foreign language teaching and meaningful gamification in education. Partners' collaboration resulted with a developed, tested and adapted e-learning platform with English, French, German, Italian, Spanish, Latvian, Polish, Bulgarian and Turkish six-unit language courses of job relevant linguistic and intercultural materials. The target audience was basic language users (A1, A2 levels, according to Common European Framework of Reference for Languages). The e-learning platform was supplemented with resource library for students and teachers, and a social network room for creating language tandems, i.e. an opportunity to practise the chosen language with native speakers.

Challenges: an increased workload; the in-depth research of meaningful gamification in education and the development of intellectual output of the project were time-critical; some issues of miscommunication, misunderstanding and commitment due to geographically and culturally diverse project colleagues, opportunely an effective and timely communication helped to clarify the critical issues.

Benefits of the teacher educator's professional development experience: expanded knowledge of gamification theory; improved technological skills through an online language course developing journey from an idea to its realisation, closely cooperating with project partners and platform system administrators; developed global competence, promoted in respectful and trust-based interaction with the diverse community of practice. Besides, the project partners were invited to participate in international teacheroriented conferences and workshops, based on their internationally-focused work.

Benefits for student teachers. First, a study course on modern technologies in foreign language studies was supplemented with a content 
on gamification; in practice, student teachers were encouraged to design their English lesson plans applying game elements and game design techniques in non-game contexts. There were students who decided to concentrate and explore further the gamification in language learning in their Term Papers. Second, a blended-learning course was offered for student teachers with basic English proficiency, thus they had an opportunity to develop a positive and constructive approach to effective oral and written communication for educational and self- improvement; moreover, they reflected and contributed in the process of testing the developed e-learning platform.

As the project occurred during the European migrant and refugee crisis, when more than a million migrants and refugees crossed into Europe in 2015, working together with professional learning communities to create the interdisciplinary online course became even more meaningful to support newly-arrived immigrants in the need of social and labour inclusion. Especially it was essential in those partnership countries which experienced the migrant and refugee crisis most of all.

Case 2. The case represents a partnership between universities, institutes and centres of research, innovation, language and competence development from Germany, Italy, Ireland, France, Latvia and Spain. The multilateral two-year project (2013-2015; Lifelong Learning Programme Project No. 543194-LLP-1-2013-1-ES-KA2-KA2MP) was carried out with an aim to address challenges of adult language learning. During the initial interaction phase the partnership was focused on the study to determine the needs of learners, language teachers and language centres for second and foreign language learning and oral expression practising in each partner country. Then a web platform containing interactive videos in English, French, German and Spanish languages was created to motivate adult learners to speak in their target language and improve oral language skills relevant to the job market.

The consortium partners transferred and further developed already existing learning platform, which was originally developed by the research group GHyM of the University of the Basque Country (Babelium Team, 2015). Face-to-face meetings and e-correspondence showed a strong impact on effective communication of project partners, especially during the video task piloting phase when even tiny but confusing technical issues were crucial to be detected, examined and tackled. Good collaboration within partnership was visible in small things.

Teacher educators and student teachers were involved to contribute during the piloting phase of the platform. Future English and German language teachers piloted videos with diverse exercises (e.g. storytelling, dubbing, conversation) for the development of communicative competences. 
In addition, they could make their own videos using simple tools (a webcam and microphone) and share with native speakers and other learners for assessment and improvement of their speaking skills, thus a collaborative learning in the network was encouraged, too. During seminars the students discussed the gained experience, provided feedback on the open-source collaborative educational tool, constructing a vision how they could use it in their teaching. Thus, the project encouraged a partnership between different teacher education study programme students and faculty within a home institution. Furthermore, an international conference was organised to introduce a wider community of teachers to different online learning tools for speaking practice in foreign languages.

Case 3. This international project (2014-2016; ERASMUS + Project No. 2014-1-TR01-KA203-011611) encouraged collaboration between teacher education universities from Croatia, Poland, Latvia, Slovakia and Turkey. The aim was to increase awareness among future language teachers of the value of learner autonomy and self-assessment; besides, the dissemination of the European Portfolio for Student Teachers of Language (EPOSTL) as a self-assessment tool and its electronic version was facilitated by partners.

Although the author of this paper was not a part of the team of two academics and eight students who were the delegated participants within the project from the home institution, this case was chosen to show the contribution of and benefits for the faculty and students during the preparation phase before two Intensive Programme (IP) meetings and project follow-up events.

The offered opportunity to join the project activities abroad could pose threats to the selected students due to their already full study schedules or provoke jealousy among other students, staying at home. Nevertheless, the faculty and fellow students worked as a team and helped to accomplish project related research assignments, e.g. students completed needs analysis questionnaires, teacher educators were interviewed and supervised the research papers, outgoing students carried out their researches, wrote reports, prepared presentations, which they practised presenting in front of their study mates. Everything required additional time commitment; however, the IP follow-up seminars let other students learn about the gained experience, best practices for self-assessment of student teachers' professional activities, thus they had an opportunity to learn and become more world and open-minded. Moreover, the collaborative learning resulted in Term Papers and Diploma Papers of student teachers, who had experienced their international mobility.

The selected cases of multilateral projects helped the author to illustrated how teacher educators and student teachers actually experience internationalisation, when being open to international cooperation and 
participation in joint educational and research projects. The cases point to the rationale for teacher educators' participation in international partnerships: to meet and collaborate with international community of practice in order to exchange specific experience and knowledge; to come up with joint research output, innovative teaching and learning methodology, approaches and tools, so bridging theory and practice; to address and meet the needs of student teachers and help them prepare for future employability, improving foreign language skills (Case 1), exploring technology enhanced language learning innovations (Case 2) or increasing one's awareness of the value of learner autonomy and teacher self-assessment (Case 3).

Projects encouraged teacher educators to open up additional opportunities for professional growth in a wider international context, apart from regular workload demands in the home institution. As a project is a unique time-related process undertaken to achieve the set aim and objectives within a defined period of time (International Standards Organisation, 2017), it should be noted that the lifetime of the described projects was concurrent. Case 1 and Case 2 revealed that any intellectual contribution and project related activity required the teacher educators' additional time commitment and increased workload. However, it was a professionally rewarding experience, especially when the key actions, project goals, objectives and timelines were clear and the expected project results and benefits contributed to the current student teachers' study process.

Consequently, a multi-project environment provided greater learning and development opportunities for more teacher educators and various student groups in the home institution, either being encouraged to support the project related activities during the piloting phase of the intellectual output (Case 1 and 2) or to participate in project dissemination and followup events (Case 1, 2 and 3). In addition, it is priceless when the teacher education institution meets the international and strategic aspirations of being recognised for research and innovation and sees the professional, research and teaching related benefits from international engagements of academics and students, promoting even short-term intensive programmes abroad, as in Case 3. The students, involved in mobility programmes, are likely to become open and internationally minded teachers in future.

\section{Conclusions}

1. This study revealed that teacher educators' openness to participation in international projects conforms to home institution's internationalisation strategy where collaboration initiatives are valued, encouraged and supported. 
2. A partnership experience can be professionally rewarding; however, it requires additional time commitment and increased workload.

3. Participation in international projects is worth the effort and contribution if academics foresee and understand how the intellectual output, project dissemination and follow-up events can provide a better study experience for students and benefits for professional development of teacher educators.

4. The focus of collaborative partnerships in teacher education is on knowledge sharing, exploration of best practices, research for bridging theory and practice, and technology enhanced learning innovations.

\section{References}

Augstskolu likums (Law on Institutions of Higher Education) (1995-2018). Rīga: Latvijas Vēstnesis. Retrieved from https://likumi.lv/ta/id/37967-augstskolu-likums.

Babelium Team (2015). Babelium Project Trainer's Guide. An Innovative ICT-based Learning Methodology for Second-language Oral Expression Practice. Retrieved from http:// llp.babeliumproject.com.

Blackmore, P., \& Blackwell, R. (2003). Academic Roles and Relationships. In: R. Blackwell, \& P. Blackmore (Eds.), Towards Strategic Staff Development in Higher Education (pp. 16-28). Maidenhead: SRHE and Open University Press.

Blūma, D. (2016). Skolotāju izglitīiba Latvijā paradigmu mainas kontekstā (1991-2000) (Teacher Education in the Context of Paradigm Shift in Latvia (1991-2000)). Izglitïbas pētniecība Latvijā, Nr. 9. Rīga: LU, PPMF, IPI.

Boyer, E. L. (1990). Scholarship Reconsidered. Priorities of the Professoriate. New York: Jossey-Bass Publishers.

Cohen, R., \& Kennedy, P. (2013). Global Sociology. Third Edition. London: Palgrave Macmillan.

Creamer, E. G. (2004). Assessing the Outcomes of Long-term Research Collaboration. The Canadian Journal of Higher Education, 34(1), 24-41.

Duffield, S., Olson, A., \& Kerzman, R. (2013). Crossing Borders, Breaking Boundaries: Collaboration Among Higher Education Institutions. Innovative Higher Education, 38, 237-250.

Eddy, P. L., \& Garza Mitchell, R. L. (2012). Faculty as Learners: Developing Thinking Communities. Innovative Higher Education, 37, 283-296.

European Commission. (2013). Report to the European Commission on Improving the Quality of Teaching and Learning in Europe's Higher Education Institutions. Luxembourg: Publications Office of the European Union.

Freedman, S., \& Katz, L. (2007). Critical Success Factors for International Projects. PM World Today, 9(10), 1-8.

Greene, J. C. (2009). Meaningfully Engaging with Difference Through Mixed Methods Educational Evaluation. In: K. E. Ryan, \& J. Bradley Cousins (Eds.) The SAGE International Handbook of Educational Evaluation (pp. 323-340). Thousand Oaks, Ca: SAGE Publications, Inc. 
Heffernan, T., \& Poole, D. (2005). In: Search of "The Vibe": Creating Effective International Education Partnerships. Higher Education, 50, 223-245.

Higgs, B., \& McCarthy, M. (Eds.) (2008). Emerging Issues II: The Changing Roles and Identities of Teachers and Learners in Higher Education. Dublin: NAIRTL.

Husso, M. L., Korpinen, E., \& Asunta, T. (2006). Teacher Researcher Net - A Forum of Interactive Professionalism and Empowerment. In: R. Jakku-Sihvonen, \& H. Niemi (Eds.) Research-based Teacher Education in Finland. Reflections by Finnish Teacher Educators (pp. 103-121). Turku: Finnish Educational Research Association.

International Standards Organisation (2017). ISO 10006. Quality Management. Guidelines for Quality Management in Projects. $3^{\text {rd }}$ edition. Geneva: International Standards Organisation.

Jarchow, E. (1997). The Dean's Role in Infusing Global Perspectives Throughout a College of Education. In: M. M. Merryfield, E. Jarchow, \& S. Pickert (Eds.) Preparing Teachers to Teaching Global Perspectives, A Handbook for Teacher Educators (pp. 209-225). London: SAGE Publications Ltd.

Klecka, C. L., Donovan, L., Venditti, K. J., \& Short, B. (2008). Who Is a Teacher Educator? Enactment of Teacher Educator Identity through Electronic Portfolio Development. Action in Teacher Education, 29(4), 83-91.

Merriam, S. B. (1998). Qualitative Research and Case Study Application in Education. San Francisco, CA: Jossey-Bass Publishers. 
https://doi.org/10.22364/htqe.2018.12

\author{
Normunds Rečs
}

University of Latvia, Latvia

\title{
THE ROLE OF A HEADMASTER IN THE ERA OF PUBLIC GOVERNANCE
}

\begin{abstract}
Changes in school management in the world over the last decades have been a part of the increasing use of comprehensive tendencies in the organization of public sector services, which is characterized by the decline of the old public administration model and a new management approach commonly referred to as public governance. Any public sector institution management in the era of public governance includes use of public administration, quasi-market and network management paradigm principles. Following these changes and in connection with the planned reform of the curriculum and teaching approach of general education in Latvia it is important to answer such questions as: what is the role of a headmaster in contemporary school and what does it mean to be $a$ headmaster - leader? The main goal of the article is to provide an overview of the main trends in the transformation of the role of a headmaster in the context of the development of public sector management and to look at the current findings of researchers in the work of headmasters. The research method is analysis of scientific publications. The article deals with the theoretical concepts of public sector management, school management and school leadership development. The author of the article concludes that the elements of manifestation of all three public sector management paradigms in the era of public governance also form the work of a headmaster, and headmaster must take the role of administrator, manager and leader at the same time. However, unlike the head of any other company or public sector institution, headmaster should focus on the leadership of the pedagogical process by improving teaching and learning and ensuring conditions for an effective learning process.
\end{abstract}

Keywords: distributed leadership, instructional leadership, pedagogical leadership, public governance, transformational leadership. 


\section{Introduction}

The improvement of school management becomes the priority of education policy worldwide (Pont, Nusche, 2008). The provision of effective school management is increasingly seen as a major large-scale educational reform, which would improve the educational outcomes (OECD, 2009). In addition, it is not expected that headmasters will become better managers or administrators than before, but that they will become leaders of the school as the learning organization (Hargreaves, Halasz, 2008; OECD, 2016). As Andreas Schleicher, the director for the Directorate of Education and Skills of the Organisation for Economic Co-operation and Development (OECD), points out, there are three key components needed to build a high-quality school in the $21^{\text {st }}$ century: (a) teachers who are confident in their ability to teach, (b) the desire to innovate, and (c) a strong school leader who promotes the conditions in the school, allowing the first two components to flourish (Schleicher, 2015).

In the context of the reform of the curriculum of general education initiated in Latvia, which also involves changing the teaching approach, the issue of the role of a headmaster has been raised. Schools will have to function as a professional learning community that are constantly changing and adapting to new circumstances to support each pupil's learning and implement a deep learning approach (National Centre ..., 2017). To implement the new curriculum and teaching approach, it will be necessary to strengthen and develop cooperation among teachers at the school level of planning and implementation of the teaching process. The new approach will require an active learning process, which means that there is nothing more important than the addressing of didactic issues in schools to match the curricula and improving educational programmes in order to regularly analyse learning outcomes and find the best ways to improve each pupil's performance so that the teachers share good pedagogical practice for teaching improvement purposes. In this way only, it will be possible to link new ideas and goals with practical teaching work, which is the task of school management. Good school management is perhaps the most important factor for introducing changes in teaching approach and ensuring school development. For a school to grow there is a need of a headmaster leader, not just a headmaster - manager (Pont, Nusche, 2008).

There is an opinion that contemporary school should be managed as any other company (Kārklina, 2013). However, in the author's opinion and based on the awareness of challenge posed by the change, it is important to find answers to such questions as: Is the school really like any other company? What is the role of a headmaster in contemporary school? What does it mean to be a headmaster - leader? To answer these questions, 
the article analyses the concepts of the transformation of the role of a headmaster in the context of public sector management development and examines the general conclusions of Western researchers and the OECD on the leadership content of a headmaster of contemporary school. Due to the limited scope the article does not include a detailed analysis of the situation and conclusions about leadership in Latvian schools, which will be discussed in subsequent publications by the author.

\section{Methods and Materials}

The research method is analysis of scientific publications in areas of public management development and school management and leadership. In the preparation of the article, general analyses and meta-analyses of leading researchers in the field of public administration and school management in the English language published in the last two decades have been used. In the general analysis of public sector governance reforms and development trends, studies from researchers of the University of Leuven Christopher Pollitt and Geert Bouckaert (Pollitt, Bouckaert, 2011), the Dutch researcher Louis Meuleman (Meuleman, 2008) and the Norwegian authors Nick Sitter and Kjell Arnold Eliassen (Eliassen, Sitter, 2008) have been used. The analysis of the transformation of the role of the headmaster and the findings of the content of management and leadership of the contemporary headmaster are based on the report by the Finnish researchers (Alava, Halttunen, 2012) and publications by the Organisation for Economic Co-operation and Development (OECD) on improving school management in the OECD countries (Pont, Nusche, 2008; OECD, 2009; OECD 2013; Schleicher 2015; OECD, 2016). The relationship between public sector governance reforms and the development of school management has been illustrated by the studies of Bill Mulford (Mulford, 2003), Petros Pashiardis and Stefan Brauckmann (Pashiardis, Brauckmann, 2009). The impact of school management and leadership on student learning outcomes is analysed in meta-analysis by the New Zealand team of researchers (Robinson, Hohepa, 2009) and studied by the University of Nottingham (Day, Sammons, 2009). In contrast, the analysis of individual school leadership patterns is based on the publications of researchers who have developed the concept of leadership in their studies: professor from the University of Toronto Kenneth Leithwood and co-authors on transformational leadership (Leithwood, Tomlinson, 1996; Leithwood, Yantzi, 2006; Leithwood, Sun, 2012); professor at the Hong Kong Institute of Education Philip Hallinger, on instructional leadership (Hallinger, 2003; Hallinger, 2009); Professor Peter Gronn of the Cambridge University and the American scientist James P. Spillane on distributed leadership (Gronn 2000; Spillane 2005; Spillane, 2015), and 
the American scholars Helen M. Marks and Susan M. Printy on integrated leadership (Marks, Printy, 2003).

\section{Results and Discussions}

School management has significantly changed over time as there has been and continues to be a significant change in the society to which they provide educational services. Under the influence of globalization and the development of information technologies public sector management transformation processes are taking place, which promotes the application of new management approaches and principles in the management of public sector institutions, including schools. Though due to the differences of organizational structure of historical, cultural and educational systems there is a different school management approach in different countries, several common global trends that affect the development of school management in all OECD countries can be observed (Pont, Nusche, 2008).

In the research (Eliassen, Sitter, 2008; Meuleman, 2008; Pollitt, Bouckaert, 2011) since the beginning of the $20^{\text {th }}$ century three public sector management development periods have been highlighted. These periods can be characterized by significant differences, emphasizing the prevailing public sector management paradigm in each of them:

- by the end of the 1970s - traditional public administration;

- from the late 1970s to the late 1990s - the new public management;

- Since the 1990s, continues the era what researchers call the public governance.

The traditional public administration corresponds to the hierarchical, bureaucratic management paradigm, the basic principles of which are in a strict compliance with norms and instructions, a hierarchical relationship, a role of a passive citizen or employee. In a traditional public administration model, the manager performs the functions of administrator. The main element of the new public sector management is the introduction of quasimarket and private sector business management principles in public administration, with the main emphasis on decentralization, competition, customer and service provider relations in the public-sector management. This paradigm management approach is dominated by managerialism, and the functions of the head of a public sector institution are somewhat similar to the work of a business manager. Over the past twenty years, with the development of communications technology, public administration has become more and more involved with such members of society as target groups and social partners by putting emphasis on the cooperation of different levels and directions of management, the paradigm of network is developing. Under the influence of these changes, heads in public sector organizations, 
including schools, must be able to fulfil new competences by taking the role of a leader. According to management theorists, public sector management approaches based on all three paradigms in public sector institution management still exists at the same time, but the intensity of each management paradigm is different - one of the approaches in practice is usually dominant (Meuleman, 2008). It should be noted that public governance combines all three public-sector management paradigms - the principles of public and quasi-market management and the use of network management methods in the public sector (Meuleman, 2008; Pollitt, Bouckaert, 2011).

The comprehensive changes in the organization of public sector services in recent decades are also reflecting in school management (Mulford, 2003; OECD, 2009), and elements of all three paradigms in public sector governance forms the content of the work of a headmaster. Consequently, the headmaster is administrator, manager and leader at the same time (Pashiardis, Brauckmann, 2009).

When assessing which of the role of a headmaster in the era of public governance is more significant, one should not forget the basic function of the school activity - the pedagogical process. As Finnish researchers point out, school management is not just administration and management, but also pedagogical and knowledge-based leadership (Alava, Halttunen, 2012). The common trends in national education system reform management practices show that more and more attention is paid to the pedagogical autonomy of schools and the responsibility for the learning outcomes (Eurydice, 2007). Such national education policy is a part of a wider trend - to restore the emphasis on teaching and learning to improve pupils' performance (Pont, Nusche, 2008). Teaching and learning or emphasizing the meaning of the pedagogical process as a school activity, as compared to the understanding of the $20^{\text {th }}$ century, significantly changes the role of a headmaster (Pont, Nusche, 2008). It is no longer enough that headmaster is a good administrator and manager. To ensure the growth of the school, the role of the leader of the school is becoming the key. In addition, the main task of headmasters is to become leaders in the pedagogical process by improving teaching and learning in schools and ensuring conditions for an effective learning process (Pont, Nusche, 2008). Headmasters are expected to take more active action in teaching management through teacher assessment and feedback to teachers on their work by organizing and leading teachers' professional collaborative teams for planning and directing the professional development of teachers. In contrast to the traditional roles of the administrator or manager, more and more emphasis is put on the primary role of the headmaster as a leader who maintains the vision and strategy of the school, constitutes the learning culture and purposefully encourages the formation of the school as the learning organization (Pont, Nusche, 2008). 
The concept of leadership of a headmaster since 80 s of the $20^{\text {th }}$ century has gradually evolved and expanded to a comprehensive school leadership perspective, which in recent years has been called leadership for learning (Hallinger, 2009; Townsend, MacBeath, 2011; OECD, 2016) or pedagogical leadership (Robinson, Hohepa, 2009; OECD, 2013; Day, Sammons, 2016). The role of headmasters is based on two major theoretical concepts of effective school leadership - the concept of transformational leadership and the concept of instructional leadership. The two concepts are also the most studied in the context of school management (see, for example, Leithwood, Jantzi, 2006; Day; Sammons; 2009; Robinson; Hohepa; 2009; Leithwood, Sun, 2012).

\section{Transformational leadership}

Transformational leadership is the theory of general management, not the theory of education management (Robinson, Hohepa, 2009). The transformational leadership approach in schools is most often associated with identifying the school vision and direction of development, school restructuring and change management, the development of employees and curricula, the involvement of the external community (Leithwood, Jantzi, 2006). Research reveals seven transformational leadership roles: building a school vision and setting school goals; providing intellectual stimulation; offering personalized support; modelling and promoting good practice and maintaining the core values of the school; demonstrating high performance expectations to create a productive school culture; creating and developing structures that promote participation in decision making at school (Leithwood, Tomlinson, 1996). The transformational leadership features emphasize school's as organization's overall development and support for people, but this leadership model lacks the element of school education process management (Robinson, Hohepa, 2009). The report, which analyses 33 studies on transformational leadership in schools, concluded that the transformational leadership model had a small indirect impact on pupil learning outcomes or social growth outcomes (Leithwood, Jantzi, 2006). Researchers conclude that the transformational leadership approach is more conducive to creating a collaborative school staff culture, rather than contributing to increased pupil learning outcomes (Robinson, Hohepa, 2009).

\section{Instructional leadership}

The theoretical model of instructional leadership emerged in the first half of the $20^{\text {th }}$ century in studies on school efficiency (Stewart, 2006). Unlike the transformational leadership, this model focuses on the way 
school leadership improves pupil learning outcomes. The initial concept of instructional leadership was essentially focusing the headmaster on how teachers work towards the aim - helping pupils to learn. Based on early studies on school efficiency, instructional leadership was designed as an active part of the headmaster in promoting school curriculum coherence, setting the key objectives, setting high academic standards, visiting classrooms regularly, monitoring teacher attitudes and encouraging better teaching (OECD, 2016).

The instructional leadership model has been developed by Philip Hallinger, a professor at the Hong Kong Institute of Education (Hallinger, 2003; Hallinger, 2009). His instructional leadership model consists of 10 leadership functions in three categories: the definition of a school mission (with such functions as definition of school goals and information about school goals); the management of the learning process (with such functions as monitor and evaluation, coordination of curriculum and monitoring of pupils' progress) and monitoring the school environment (including learning time protection, promoting career development, raising awareness of the school, stimulating teachers and motivating them).

When analysing disadvantages of instructional leadership model, the researchers conclude that in many schools the headmaster is not a learning expert (Stewart, 2006). In addition, some headmasters think that their main function is merely administration, and therefore they are purposefully distanced from what is happening in the classroom. Hallinger also points out that in many cases headmasters have less knowledge of pedagogy and curriculum than teachers which they monitor. Furthermore, decentralization and the increase in the degree of autonomy of the school also diverts the headmaster's attention from the main mission of the school. Many headmasters are so overtaken with school management and administrative routine tasks that they rarely have time to influence and inspire others in teaching and learning (Hallinger, 2003).

Both of these leadership approaches vary depending on which school areas of activity headmasters and teachers focus to improve pupils' teaching and learning. Meta-analysis by the New Zealand researchers on the impact of different leadership approaches on pupil learning outcomes has concluded that the impact of instructional leadership is three to four times higher than the impact of transformational leadership (Robinson, Hohepa, 2009). The reason for such a significant dominance of the impact of the instructional leadership approach on the results of pupil learning outcomes is that the transformational leadership model focuses more on the relationships between leaders and their followers and on school restructuring, improving school conditions in general, and these processes do not have a direct impact on the quality of pupil learning outcomes 
(Robinson, Hohepa, 2009). Instructional leaders, in turn, focus on school goals, curriculum development, learning and school environment (Stewart, 2006).

\section{Distributed leadership}

Over the last two decades, the initial concept of a headmaster as a sole leader in teaching, which has been actively involved in all learning process issues, has gradually changed as it did not involve the influence and leadership of other school staff. This lack of this instructional leadership concept has contributed to the development of the concept of distributed leadership model (Gronn 2000; Marks, Printy, 2003; Spillane, 2005; Spillane, 2015).

The concept of distributed leadership is based on the hypothesis that leadership is not a feature of one person or a person's leader role, function or behaviour, but rather the whole organization's characteristic. Respectively, leadership is distributed within the organization (Gronn 2000; Spillane 2005). It is formed by an interaction between the various employees of the organization and the environmental conditions, namely, it is a product of formal leaders and employees (leader's followers), as well as the interaction of circumstances and situation (Gronn 2000; Spillane 2005; Spillane, 2015). In addition, not only the leader affects the followers, but the followers influence the leaders as well in this interaction (Spillane, 2015).

Researchers emphasize that distributed leadership approach does not involve delegation or transfer of leadership to other school staff, but rather the dispersion of leadership roles within a wider range of staff, while ensuring a joint, coherent activity and emphasizing interaction between the headmaster and school staff (Fullan, 2003, Spillane 2005; Spillane, 2015).

When analysing this leadership approach in the context of public sector management paradigms, the author concludes that the distributed leadership model is in line with the public governance network paradigm, because it involves refusing of the traditional hierarchical structure in organization management, replacing it with self-organizing networks in which employees form the necessary structural interrelationships. Consequently, the management model of the leadership network enables organizations to create professional learning communities that allow employees to learn from one another, making the organization a learning organization.

\section{Integrated leadership model - pedagogical leadership}

In recent years, public sector researchers have begun to develop and test integrated leadership models that combine elements from the 
original separate leadership concepts (Fernandez, Cho, 2010). Education management in this regard is no exception. Effective school management practices describe several integrated leadership models (Marks, Printy, 2003; Hallinger, 2009; Townsend, MacBeath, 2011; Day, Sammons, 2013; OECD, 2016). American scholars Helen M. Marks and Susan M. Printy suggest that leadership in school management is seen in a wider context by combining instructional leadership and transformational leadership concepts and justifies the opinion that there is a need of transformative leadership in school to promote the changes, but distributed instructional leadership is required to improve learning outcomes (Marks, Printy, 2003). According to researchers, the two leadership theories in the context of school management are not mutually exclusive and the implementation of the management principles discussed in contemporary schools can improve pupil learning outcomes by supporting and promoting teaching and learning conditions that have a direct impact on teachers and their work (Day, Sammons, 2013).

In recent years, the term "pedagogical leadership" is used to describe the integrated leadership model (Robinson, Hohepa, 2009; OECD, 2013; Day, Sammons, 2016), thus covering all school management activities which are focusing on teaching and learning.

The transformational leadership component in the pedagogical leadership model emphasizes the role of the headmaster leader in improving school environment. In practice, this implies the headmaster focusing on what might be called "secondary processes", shaping the organization and culture of the school, and improving the skills of the staff. In the context of transformational leadership, one of the main tasks of a headmaster is to promote processes within the school framework and to create structures that ensure mutual professional cooperation between teachers and their participation in decision-making. This approach is based on the fact that teachers in many schools work autonomously and in isolation, which means that the headmaster should, instead of directly engaging in the learning process, promote the formation of a teacher-centred learning community aimed at improving school performance. In other words, the main task of the headmaster is to create a working environment in which teachers are strongly aware of the school's mission, cooperate with and learn from each other (Hendriks, Scheerens, 2013).

The component of distributed instructional leadership in a pedagogical leadership model in school means cooperation between the headmaster and teacher in improving curricula, teaching and assessment. The headmaster stimulates teacher's engagement and development and works together to improve learning process. Consequently, in the pedagogical leadership model, the headmaster is no longer the only teacher who is solely 
responsible for instructional leadership initiatives at school but is a "leader in pedagogical leadership" (Stewart, 2006). In this context, the main task of the headmaster as a pedagogical leader is to focus on the emphasis and support of teaching and learning in schools and the promotion of the professional development of teachers to ensure that all teachers know how and can improve pupil performance (OECD, 2016). Thus, headmasters pedagogical leaders - set goals, ensure that pedagogical staff is competent in executing their duties, assesses whether the goals have been achieved, provides teachers with feedback on their work and necessary improvements (Robinson, Hohepa, 2009).

\section{Conclusions}

- In the era of public governance, the headmaster must play the role of administrator, manager and leader at the same time. However, unlike manager of any other company or public sector institution, the headmaster should focus primarily on pedagogical leadership, emphasizing teaching and learning as the meaning of school activity.

- Pedagogical leadership is an integrated leadership model, which consists of the elements of the concepts of transformational leadership and distributed instructional leadership.

- In the context of transformational leadership, the role of a headmaster is to create school environment in which teachers are strongly committed to the mission of the school by interacting with each other professionally and learning from one another.

- Distributed instructional leadership component in the pedagogical leadership model means cooperation between the headmaster and teacher in improving curricula, teaching and assessment.

- In the pedagogical leadership model, the headmaster is leader of pedagogical leaders who sets goals together with teachers, ensures that teachers are competent in execution of their duties, assesses whether the goals have been achieved, provides teachers with feedback on their work and necessary improvements.

\section{References}

Alava, J., Halttunen, L., Risku, M. (2012). Changing School Management. Status review May 2012. Helsinki: Finnish National Board of Education.

Day, C., Sammons, P. (2016). Successful School Leadership. Education Development Trust.

Day, C., Sammons, P., Hopkins, D., Harris, A., Leithwood, K., Gu, Q., Brown, E., Ahtaridou, E., Kington, A. (2009). The impact of school leadership on pupil outcomes: final report. London: DCSF. 
Eliassen, K. A., Sitter, N. (2008). Understanding Public Management. SAGE Publications. Eurydice (2007). School Autonomy in Europe. Policies and Measures. Brussels: Eurydice.

Fernandez, S., Cho, Y. J., Perry, J. L. (2010). Exploring the link between integrated leadership and public sector performance. The Leadership Quarterly, 21, 308-323.

Fullan, M. (2003). The moral imperative of school leadership. Thousand Oaks: Corwin Press.

Gronn, P. (2000). Distributed Properties: A New Architecture for Leadership. Educational Management Administration \& Leadership, 28, 317-338.

Hallinger, P. (2003). Leading educational change: Reflections on the practice of instructional and transformational leadership. Cambridge Journal of Education, 33 (3), 329-351.

Hallinger, P. (2009). Leadership for $21^{\text {st }}$ Century Schools: From Instructional Leadership to Leadership for Learning. The Hong Kong Institute of Education.

Hargreaves, A., Halasz, G., Pont, B. (2008). The Finnish approach to system leadership. In: Pont, B., Nusche, D., Hopkins, D. (Eds.), Improving School Leadership, Vol. 2: Case Studies on System Leadership (pp. 69-110). Paris: OECD.

Hendriks, M. A., Scheerens, J. (2013). School leadership effects revisited: a review of empirical studies guided by indirect-effect models. School Leadership \& Management, 33(4), 373-394.

Kārkliṇa, D. (2013). Skola jāvada kā uzṇēmums, bet - kā radošs uzṇēmums. Diena, 29.11.2013. (in Latvian). Retrieved from http://www.diena.lv/skolas-diena/skolajavada-ka-uznemums-bet-ka-radoss-uznemums-14034872.

Leithwood, K., Jantzi, D. (2006). Transformational school leadership for large-scale reform: Effects on students, teachers, and their classroom practices. School Effectiveness and School Improvement, 17(2), 201-227.

Leithwood, K., Sun, J. (2012). The Nature and Effects of Transformational School Leadership: A Meta-Analytic Review of Unpublished Research. Educational Administration Quarterly, 48(3), 387-423.

Leithwood, K., Tomlinson, D., Genge, M. (1996). Transformational school leadership. In: K. Leithwood, J. Chapman, D. Corson, P. Hallinger, Hart, A. (Eds.), International handbook of educational leadership and administration (pp. 785-840). Dordrecht: Kluwer Academic.

Marks, H. M., Printy, S. M. (2003). Principal Leadership and School Performance: An Integration of Transformational and Instructional Leadership. Educational Administration Quarterly, 39(3), 370-397.

Meuleman, L. (2008). Public management and the metagovernance of hierarchies, networks and markets: the feasibility of designing and managing governance style combinations. Springer.

Mulford, B. (2003). School leaders: challenging roles and impact on teacher and school effectiveness. OECD commissioned paper.

National Centre for Education of the Republic of Latvia (2017). Skola 2030. Izglitiba mūsdienigai lietpratibai: mācību satura un pieejas apraksts. Projekta Nr.8.3.1.1./16/I/002 "Kompetenču pieeja mācību saturā" materiāls sabiedriskajai apspriešanai. Rīga: VISC (in Latvian). 
OECD (2009). Creating Effective Teaching and Learning Environments. First Results from TALIS. Paris: OECD.

OECD (2013). Leadership for $21^{\text {st }}$ Century Learning. Educational Research and Innovation. Paris: OECD Publishing.

OECD (2016). School Leadership for Learning: Insights from TALIS 2013. Paris: OECD Publishing.

Pashiardis, P., Brauckmann, S. (2009). Professional development needs of school principals. In: Commonwealth Education Partnerships (pp. 120-124).

Pollitt, C., Bouckaert, G. (2011). Public management reform: a comparative analysis: New Public management, Governance and the Neo-Weberian State. Oxford: Oxford University Press.

Pont, B., Nusche, D., Moorman, H. (2008). Improving school leadership, Vol. 1, Policy and practice. Paris: OECD Publishing.

Robinson, V. M. J., Hohepa, M., Lloyd, C. (2009). School Leadership and Student Outcomes: Identifying What Works and Why. Wellington: New Zealand Ministry of Education.

Schleicher, A. (2015). Schools for $21^{\text {st }}$ Century Learners: Strong Leaders, Confident Teachers, Innovative Approaches. International Summit on the Teaching Profession. Paris: OECD Publishing.

Spillane, J. P. (2005). Distributed Leadership. The Educational Forum, 69, 143-150.

Spillane, J. P. (2015). Leadership and Learning: Conceptualizing Relations between School Administrative Practice and Instructional Practice. Societies, 5, 277-294.

Stewart, J. (2006). Transformational Leadership: An Evolving Concept Examined through the Works of Burns, Bass, Avolio, and Leithwood. Canadian Journal of Educational Administration and Policy, 54, 1-29.

Townsend, T., \& MacBeath, J. (Eds.) (2011). International Handbook of Leadership for Learning. Springer. 


\title{
IMAGINATION AS PART OF LITERATURE STUDY PROCESS IN SECONDARY SCHOOL LEVEL
}

\begin{abstract}
In creative culture, as well as in scientific and methodological literature, the question of how the human mind works is in its renaissance. Consequently, education content and teaching methods should also be in line with modern requirements, as pupils of today tend to reject knowledge and teaching if they do not see personal significance in them. It is important to look for new learning approaches, focused on the pupil's personality. Pupils have to become much more active participants in their learning, while teachers must perfect themselves professionally to provide knowledge, develop pupil's skills and to efficiently implement interdisciplinarity in different study fields, thus fostering pupil's cognitive interest, empathy, personality; paying special attention to learning and thinking processes (how one learns and how one thinks). Therefore, the question that arises is how to associate critical thinking with creativity and how to promote creativity, developing the pupil's imagination as a personality cognition promoting factor. The aim of this article is to draw attention to the promotion of imagination in secondary school literature study process from three aspects: imagination and language; imagination and co-operation; imagination and creation. A topical problem is how to promote a versatile imagination in the pupils through various pedagogical means, and how the competence of secondary school pupils acquired during school hours is related to the importance of imagination in thinking and to the synthesis of acquired knowledge, creating new original conclusions, cultivating these pupils' self-expression and self-experience.
\end{abstract}

Keywords: cognition, co-operation, imagination, self-expression, study process.

\section{Introduction}

Research on creativity often refers to an essential component of thinking processes i.e. imagination. The phenomenon of imagination is a subject of philosophy, psychology and pedagogy. Traditionally, imagination is 
explained as a mental process, creating something new in consciousness in the form of a picture, a vision, an idea, and a figurative concept. The notion of imagination is often understood in a simplified way and as synonymous with the notion of imagining: to characterize, to show something different than it is in reality, to portray, for example, to imagine what is desired to be real. Classically, creativity and imagination are thought to be the ability to find new solutions to a particular problem (Guilford, 1967). Imagination is a natural feedback that each person is endowed with, for it creates feelings, and feelings lead to action. Imagination is like a tool for self-programming (Vidnere, 2015). Imagination and associations are the foundation of deep thinking (Smith \& Colby, 2007) and memory enhancement, therefore Buzan (2008) offers a witty game of letters and notions called "I AM", where I stands for imagination, A for associations and $\mathrm{M}$ for memory.

Understanding a literary text from the aspect of content, as well as form, has always been a challenge, as one can often observe rational associations, the inertness of imagination, the inability to get into the characters or situations. Literature teaching methodology researcher in Latvia and Doctor in Pedagogy Rudzitis (2000) points out that one of the causes of failure is the inadequacy of teaching methods to the specificities of the study of fiction as a verbal art form. This discrepancy manifests itself in the excessive application of logic to these art works, the emotional imagery impoverishment (Rudzītis, 2000).

Why is it in secondary school specifically that it is important to master literature as an art subject? Because in the secondary school level pupil's perception of the world begins to resemble that of an adult; pupils become more critical and demanding towards themselves and teachers, secondary school pupils are better able to see the interdisciplinarity of their subjects, they become aware (although occasionally they do not) of the importance of literature teaching to their future life. Instructional activity, secondary school level included, is one that promotes or impedes motivation of personal activity, extends pupil self-experience, because the competence acquired in literature lessons is related to the following manifestations of emotional intelligence: recognition and management of one's emotions, recognition of other people's emotions, empathy, ability to form diverse relationships with peers (Šteinberga, 2013). Therefore, the development of imagination in the literary learning process is manifests itself as a significant component of self-expression, self-assertion and introspection.

When looking for an answer to one of the most important questions about the conditions for thinking and knowledge, researchers in philosophy, psychology and pedagogy are confronted with the problem of imagination. Even Aristotle (2008) paid attention to the fact that thinking was impossible without images. Imagination as a challenge for thought is one 
of the research subjects of hermeneutics by Gadamer (1999) and Ricoeur (1976), emphasizing that preconditions for personal freedom and thinking are based on imagination. Creativity and imagination are an integral component of many fields of knowledge and skills, i.e. science, mathematics, business, design, and arts. A pedagogical activity that stimulates imagination develops thinking, for it integrates what has been learned in the other subjects and reveals the interconnections between different fields. Albert Einstein's conclusion - "Imagination is more important than knowledge. For knowledge is limited to all we now know and understand, while imagination embraces the entire world, and all there ever will be to know and understand" - has already become an aphorism (Fadel, Bialik, \& Trilling, 2017, p. 74).

In phenomenology, imagination is viewed not as a reproductive and also as a productive act of consciousness; imagination is not an empty play of images, it is a tool of truth and creative discernment, and thus the preconditions for human freedom based on imagination (Narkēviča, 2010). However, to be free is to create. This is why in a literature class it is essential to organise perception of the text as a creative thinking activity. The development of imagination ensures that learning activities are not only reproductive, they are also creative.

\section{Imagination and Language}

From the point of hermeneutics, human experience derives its ultimate fulfilment not from any aggregated knowledge but from openness to the experience that comes with life experience. (Ricœur \& Thompson, 2016) in his studies also goes from phenomenology of imagination to hermeneutics of imagination, viewing imagination as a language dimension, because language is the place where imagination is recorded, strengthened in longevity (Narkēviča, 2010, pp. 7-8).

Literature is an art of the word. What does it mean to master a language? Hermeneutics offers a philosophical conclusion that "we are linguistic residents" because "language does not manifest in statements, it is realized as a conversation, as a unit of meaning which is shaped by a question and an answer. Any statement is a fragment of a dialogue, a conversation, through which and in which the language lives" (Gadamer, 2002, p. 12). In the context of hermeneutics, Gadamer (2002) explains that understanding is misunderstanding at the same time. Consequently, the subject of understanding is the language itself, where understanding becomes an endless task of human life. Significant is the way to get behind the pronounced, closer to the essence of language, also to soul of what has been expressed, and then understanding the text becomes the continuation 
of the conversation started. Gadamer (2002) adds something important: the soul of hermeneutics is characterized by the ability to recognize another truth; the fundamental principle of philosophical hermeneutics is a conversation and a dialogue.

"Paul Ricoeur shows that the reader's relationship with the text is their relationship with the world that the text offers us. A read goes beyond the borders of the linguistic theory. This is an existential activity in which the reader, by following the meaning of the text, finds the reference - the world showed by the text. The culmination of a read is the acquisition of the meaning of the text, which the reader appropriates (...)" (Ābels, et al., 2015, p. 421), thus, reading is a creative activity that results in new images and imaginative models. When addressing different levels of language use, notes that besides an informative nature a language also carries a specific kind of beauty, because speech creates reality, presenting human knowledge of the world in its different aspects (Tinjakova, 2018, p. 15).

The text comprehension process makes one ask various questions. Why, when reading the same text at different stages and situations of life, the same reader notices new details that they did not notice before? Why are new reading variants continuously appearing in the text? What is it that gives the language a dimension of depth? Gadamer explains that there a meeting takes place between the reader and the worlds of the text, and he emphasizes the purpose of the interplay between imagination and understanding, as if one could somehow get behind what has been said (Gadamer, 2002, p. 67). In these interactions between understanding and imagination, when imagination is reproductive, yet also a productive act of consciousness, the pupil's self-realization takes place. The so called "full picture" continues beyond the work of art and text, it should be perceived with the "third eye" or the "sixth sense". The essence lies in the search for differences, in noticing nuances, in training the focus, in alertness.

The cognitive process activity (perception, conception, memorization, comprehension and others) is stimulated by the pupil's cognitive process activity. Depending on the purpose of the teaching, learning reflects the nature of studies; it can be reproductive, interpretative or productive (Žogla, 2001).

Pupils themselves appreciate the literature lessons. Last year's pupil of Secondary School wrote: "Literature inspires me. Every time I read something new, I understand how much I still have to discover about myself. A new book is a new chance to discover something new and unknown. Literature is a science linked to philosophy, imagination, language, understanding of life. Literature is like a synonym to the concept of thinking on the highest level. Sophisticated thinking is start for a good life. Book reading improves 
personality and inner faces of one's character, it highlights how different and unique we all are."

\section{Artistic Inquiry and Imagination as Co-operation in Literature Lessons}

Philosophical hermeneutics is opposed to an overly narrow understanding of a text, it is explained as a semiotic structure closed in itself that has no connection to reality (Ābels, et al., 2015, p. 419). A text (including those of fiction) acquires its meaning if it becomes part of a person's search for truth and part of knowing oneself, if the text is able to reach the thoughts of its reader, to change their attitude and behaviour. Often poetic texts are those that are capable of reaching those layers of human existence that are difficult to rationalize and to be expressed in a language. Owing to the means of expression of the poetic language, narration or poem is able to "collect" the messy and fragmentary human life experiences in a single, coherent whole (Ābels, et al., 2015, p. 422).

Therefore, it is important to teach literature in secondary school as an art subject. This realization has been well explained by Riga Technical University professor and Doctor in Psychology Šteinberga in an interview about School Reform in Latvia: "Once the secondary school level is reached, there is a need to learn the foundations of philosophy, to develop their own views on life, to create conscious values. There is no use to talk about values any sooner than when they are understandable and comprehensible. Each type of attitude has its sensitive developmental period. (...) We worry that the child has no motivation, although first we need to know whether what we are doing corresponds to their age and their needs" (Klanska, 2018, p. 10). Art cannot be understood at a glance. In order to understand the symbol language and the subtexts, the pupil must be mature enough, on their intuitive way to internal freedom. In the same interview professor from the University of Latvia and Doctor in Pedagogy Špona added: "Learning is self-expression. If one does not have the chance to express themselves in the class, then they do not know what to do further with themselves in order to pursue a purposeful development. Freedom is free will and self-realization" (Klanska, 2018, p. 10). A pupil's competence will only arise if they come to the conclusion by themselves. A conclusion is arrived at through reason, through teacher-pupil cooperation. Human thinking abilities mature not by themselves, they only do so in contact with the world, its objects and individuals (Piaget, 2002). Therefore, the result of literature learning is often not immediately visible and measurable, since the process of co-operation itself is more relevant than the apparent result. It is precisely the openness to new experiences, 
through interaction, that directs students towards the subjective quests for meaning.

Some researchers have noted that creativity is highly determined by motivation. The scientific creativity is highly dependent on motivation, especially intrinsic motivation. Therefore, the overall classroom environment, aimed at improving pupils' intrinsic motivation is essential (Zulkarnaen, Supardi, \& Jatmiko, 2017).

The literature learning process has the advantage of using artistic inquiry as a co-operation where there is a mutual exchange of spiritual values between pupils, an also between pupils and teachers, where differences of opinion are tolerated and even desirable as a manifestation of critical thinking; the student searches, analyses, discovers interrelations, develops the skill to evaluate, interpret, to express an opinion, to express creatively. It is important not only to coordinate literature as an art subject with the content and methodological basis of other art subjects, but also to plan it as a subject that organises the experiences of values.

Rudzitis (1994) emphasizes the value orientating aspect of fiction as an art of words and suggests that the study of literature in school should be interpreted broadly as a circulation process of culture, particularly aesthetic culture, in which a significant place is given to the revelation of life and art values. The actualization of life and art values, and the development of such skills in pupils are all methodically important for these pupils to be capable of defining and discovering values important in their own lives (Rudzitis, 1994, p. 5). Fiction art works, their ideas, images, ideals, artistic values are perceived, felt and understood as aesthetic experiences, therefore it is important to seek a balance between the intellectual and emotional components by the use of both reproductive and productive imagination and by promoting self-actualization.

\section{Imagination and Creation}

The understanding of art, including literature, is perfectible and directable. An artwork is never really fully discoverable and understandable, therefore, to a greater or lesser extent it cannot be fully finished in the imagination. Contact with an artwork is at the same time watching it, experiencing it, understanding it, transforming it creatively in the imagination, subjecting it to personal interpretation and enjoyment and satisfaction for the success of these activities.

Creativity in learning process can take many forms, although usually it is linked to artistic creativity and creation of artworks. Purēns notes that several components are important in this process: topicality, experience, emotions, opinions and heritage. For a pupil, creation of an artistic artwork 
can be a cognitive process where they can better discover regularities in art creation and cultivate self-actualization (Purēns, 2017, p. 97).

Creativity in literature lessons can be acted in different ways, both as cocreation and as creative writing, as the generation and implementation of new ideas, as well as co-operation, for example, by working in groups and by conveying their ideas to the members of the group, classmates, teacher, thereby promoting mutual understanding, exchange of opinions, mutual trust. The creative process helps self-expression, develops self-esteem. Creativity and imagination tasks in literature lessons develop skills, selfexamination, and they become more attentive towards the language, the pleasure of learning a language is growing. The Secondary School pupils themselves, in spite of their lack of education in pedagogy, intuitively value and acknowledge the importance of the literature study process and the creative imagination tasks to their personality development. This is evidenced by a reflection written by a pupil: "Literature is not just a study subject, it is a vast science in which everyone can find their place even if they do not like to read or write. Each autumn our school produces a performance of poetry, music and movement. I participated in it last year and I was surprised both by my ability to read a poem in front of a large audience and by the fact that my involvement in this event touched me quite a bit, creating a pleasant emotional uplift. This indicates that the activities related to literature can have diverse effects, and for me it is positive. It seems to me that it depends on the topic and that it is important to participate actively. Even if your contribution is small, it feels like you are part of everything. It's all based on the hidden power of literature, which makes you get to know and understand yourself, because before this performance I did not expect that these would be my memories. The tasks range from learning a poem by heart, text reading, visualization to presentation and research. I am lazy doer, but when really go into it, literature does not let me go, because literature is study of oneself. I call this process self-exploration. In my opinion, people must be encouraged to take interest in literature as it offers more opportunities and makes people freer."

The words of this pupil are conformed by research of philosophers and educators. For example, Play, Symbol, Festival - these are the objects of Gadamer's (2002) philosophical hermeneutics study where some of the qualities of the play mentioned are the following: play as a free impulse; the aimless rationality of the play; a play involves co-playing; a play as reflection; a play as a communicative action, which all together develop the "depth dimension of perception" (Fadel, Bialik, \& Trilling, 2017). This is a peculiar reinterpretation. All this is actualized in the self-expression of the pupils. Any contact with art must be developed and directed. An artwork is "discovered"; it can be more or less completed in the imagination. This 
apparent uncertainty, the acquisition of certain fast-evaluable results, problems in evaluating creative work lead to discussions about the usefulness of the literature subject (Rudzitis, 2000).

Literature education promotes aesthetic sensitivity and language development, the development of fancy and communication, empathy, identity formation, the formation of a social opinion and knowledge on reality (Skalberga, 2012). Like art, literature does not conform to normativity, it encourages critical thinking and awareness of your national identity as part of the world cultural space, it develops self-expression and self-confidence in a person, forms a student into a free, responsible, independent, creative personality.

\section{Methodology}

The work has been drafted under the cultural-historical approach and with attitude that humans are the highest value in society. Studying literature as an art subject is not possible without gaining philosophical insights on the significance of imagination its cultivation in pupils in the learning process. Therefore, the following methods are used in this study: literature analysis, revealing interconnectivity, analysis of one's own experience.

\section{Results}

During the research theoretical correlations were discovered between imagination and language, imagination and co-operation, imagination and creativity, revealing the significance of promoting imagination in the literature study process as well as in cultivating self-expression in the students (see Table 1).

\section{Discussion and Conclusions}

Literature essays, functions of literature, its teaching at school, artistic and ethical values, artistic perceptions have always been subject to acute arguments and discussions, and the literature subject should justify its meaning and significance from time to time. For example, one might defend the fictional cat from a Kārlis Skalbe's story for children "The Cat's Mill", who from an everyday point of view had an unsuccessful business project. When the cat loses it all, he doesn't lose his self-respect and continues to believe that people have good in them. This story repeatedly has raised in the Latvian cultural space, as well as in the context of education program planning discussions on fundamental values and the role of fiction in the 
Table 1. Interconnections with imagination in the literature study process

\begin{tabular}{|c|c|c|c|}
\hline $\begin{array}{l}\text { Interconnec- } \\
\text { tion }\end{array}$ & $\begin{array}{l}\text { Imagination and } \\
\text { language }\end{array}$ & $\begin{array}{l}\text { Imagination and } \\
\text { co-operation }\end{array}$ & $\begin{array}{l}\text { Imagination and } \\
\text { creativity }\end{array}$ \\
\hline Detection & $\begin{array}{l}\text { Imagination as } \\
\text { an initiator of } \\
\text { new thoughts or } \\
\text { associations } \\
\text { "Language is } \\
\text { the place where } \\
\text { imagination } \\
\text { is recorded, } \\
\text { strengthened in } \\
\text { longevity" } \\
\text { (Narkēviča, 2010, } \\
\text { p. 8). }\end{array}$ & $\begin{array}{l}\text { Imagination as } \\
\text { co-operation } \\
\text { Exchange of } \\
\text { individual ethical } \\
\text { and aesthetic } \\
\text { values, interests and } \\
\text { creation of joy and } \\
\text { empathy } \\
\text { "Human thinking } \\
\text { abilities mature not } \\
\text { by themselves but } \\
\text { in contact with the } \\
\text { world, its objects } \\
\text { and individuals" } \\
\text { (Piaget, 2002). }\end{array}$ & $\begin{array}{l}\text { Imagination as } \\
\text { co-creation and new } \\
\text { creation } \\
\text { Openness to a new } \\
\text { experience because } \\
\text { of one's own } \\
\text { experience } \\
\text { "Imagination is } \\
\text { art hidden in the } \\
\text { depths of the soul, } \\
\text { without which we } \\
\text { would have no } \\
\text { cognition at all" } \\
\text { (Kant \& Kūlis, } \\
\text { 2011). }\end{array}$ \\
\hline Understanding & $\begin{array}{l}\text { Conversation, dia- } \\
\text { logue } \\
\text { Text reading (work } \\
\text { with text) as a } \\
\text { creative activity } \\
\text { Grasp and } \\
\text { imagination - } \\
\text { self-realization } \\
\text { Imagination as a } \\
\text { reproductive and } \\
\text { productive act of } \\
\text { consciousness }\end{array}$ & $\begin{array}{l}\text { Interactive } \\
\text { co-operation: } \\
\text { pupil - pupil } \\
\text { pupil - teacher } \\
\text { teacher - teacher } \\
\text { Artistic inquiry - } \\
\text { Understanding } \\
\text { yourself and the } \\
\text { world through } \\
\text { artwork } \\
\text { Pupils come to } \\
\text { conclusions by } \\
\text { themselves - } \\
\text { Self-actualization }\end{array}$ & $\begin{array}{l}\text { Synthesis } \\
\text { Deep learning, } \\
\text { generalization } \\
\text { Extended } \\
\text { abstraction } \\
\text { Play - facilitator of } \\
\text { self-expression }\end{array}$ \\
\hline Application & $\begin{array}{l}\text { New images } \\
\text { (figurative models) } \\
\text { Introspection }\end{array}$ & $\begin{array}{l}\text { Value-orientating } \\
\text { co-operation } \\
\text { Self-guided learning }\end{array}$ & $\begin{array}{l}\text { Creative work } \\
\text { Self-expression in } \\
\text { action }\end{array}$ \\
\hline
\end{tabular}

learning process. The most important message in this story is in the subtext message of love and forgiveness, because "Why should one amplify the pain? Let us amplify the joy instead! (Skalbe, 1998)". This realization is still relevant today in the $21^{\text {st }}$ century. This problem was also discussed in a Latvian television series episode where the main question was whether Latvian literature could be dangerous to mental health (Latvijas Televizija, 2017). Literature and pedagogy science experts contradicted the view that only successful people should be portrayed in literature since art works filled 
with problem situations and issues could affect pupils' mental health. This view demonstrates that sometimes vulgarization, simplification, superficial understanding of literature as a work of art takes place, because an art work does not necessarily need to have a didactical purpose. Educational, value orientating goal emerges in the process of analysing and interpreting the artwork by contemplating, co-experiencing and co-creating it.

By analysing the literature of philosophy, psychology and pedagogy, the author broadens the understanding of the role of imagination in thinking in the process of studying literature in Secondary School and reveals correlations where imagination is a factor contributing to the personal cognitive activity. The study and analysis of the theoretical literature reveals the interrelations between imagination and language, where imagination is an initiator of new thought and association; significant interrelations between imagination and cooperation, where interactive collaboration provides for the exchange of individual ethical and aesthetic values; and the close interrelations between imagination and creation, which through cocreation and novel creation provide openness to new experiences and strengthens self-confidence. The versatile imagination of pupils can be stimulated if the teacher is aware of the importance of imagination in thinking processes and various pedagogical tools such as creative tasks, the creation of joy and empathy, value-orienting co-operation and creativity, aimed at encouraging motivation and self-expression in action, illustrated in this publication by author's self-experience and passages from pupil writings. Imagination stimulating activities develop thinking, because it integrates what has been learned in other subjects, discovering the interconnections between different fields.

Literature critic and Doctor of Philology Bībers (1986) says that fairytale heroes love paths. However, these paths are not so much paths in the world, paths leading to the transformation of the world, as they are paths leading to oneself, self-exploration and transformation of the self. These words also apply to the path of cognition and knowledge acquisition as a whole, because only through the self-exploration and self-improvement is it possible to discover, achieve and create something. When being aware of the meaning of imagination, it is possible to enrich the literature lessons as well as the emotional world and the world of values of the pupils, stimulating both emotional and logical thinking processes and discovering a creative thinking energy in oneself.

There is no unified understanding of the essence of pedagogy, educational science, pedagogical psychology, art, and culture. Also, the teaching methodology stands for not one single, universally productive teaching model, it directs teachers' thinking in a way that they can look for and find optimal options for co-operation with the pupils, in accordance 
with the professional competence of the teacher. In the literature learning, the process itself is often more important than the measurable results, creating long-term feedback and student self-realization, as one of the tasks of the literature teacher is to develop pupils' self-activity and selfexpression. "The highest human freedom is to interpret yourself into the most beautiful sound that one can make of themselves. This is the ultimate purpose" (Ziedonis, 1999). The author would very much like to believe that, in the framework of School Reform in Latvia, literature studies in secondary school level will rise to a new quality, because the literature learning process develops imagination, imaginative and analytical thinking, promotes the subtle mental force that forms a person into a personality with a critical mind and a sensitive heart into a free, responsible, independent and creative personality.

\section{References}

Aristotle (2008). Poētika (Poetics). Ģiezens, A. (Transl.). Rīga: Jāņa Rozes apgāds.

Ābels, G., Bičevskis, R., Dāboliņ̌š, A., Derflingers, B., Gedina, L., Hefe \& O., Kiope, M. (2015). Kants, Heidegers un dzives pasaule (Kant, Heidegger and the World of life). Riga: Institute of Philosophy and Sociology, University of Latvia.

Bībers, G. (1986). Drāmas teorijas jautājumi (Drama Theory Questions). Rīga: P. Stučkas Latvijas Valsts universitāte.

Buzan, T. (2008). Efektivas mācǐšanās rokasgrāmata (The Buzan Study skills handbook). Teibe, I. (Transl.). Rīga: Jāña Rozes apgāds. (Original work published 2007).

Fadel, C., Bialik, M. \& Trilling, B. (2017). Četru dimensiju izglitiba (Four-dimensional education: The Competencies learners). Lielvārde: Lielvārds. (Original work published 2015).

Gadamer, H. G. (1999). Patiesiba un metode (Truth and Method). Šuvajevs, I. (Transl.). Rìga: Jumava. (Original work published 1979).

Gadamer, H. G. (2002). Skaistā aktualitāte: Māksla kā spēle, simbols un svētki (The Relevance of the Beautiful: Art as Play, Symbol and Festival). Šuvajevs, I. (Transl.). Rìga: Zvaigzne ABC. (Original work published 1977).

Guilford, J. P. (1967). The nature of human intelligence. New York: McGraw-Hill.

Kant, I. \& Kūlis, R. (2011). Türā prāta kritika (Pure mind Criticism). Rīga: Zinātne.

Klanska, D. (2018). Iedzīvināsim pieeju mācīties darīt un jebkuru soli sāksim ar attieksmi (Let us revitalize our Approach to Learning how to be active and let us start with our Attitude). Izglitiba un kultūra, 2(534), 10-11.

Latvijas Televīzija. (2017, October $20^{\text {th }}$ ). Vai latviešu literatūra ir bīstama cilvēka psihiskajai veselïbai? (Is Latvian literature dangerous to personal mental health?) [Television series episode]. In: LTV1 Kultūršoks. Rīga: Latvijas Televīzija.

Narkēviča, Ž. (2010). Iztēle un valodas jaunrade Pola Rikēra filosofijā (Imagination and Creativity of Language in the Philosophy of Paul Ricoeur). Doctoral dissertation. Retrieved from https://dspace.lu.lv/dspace/handle/7/4548. 
Piaget, J. (2002). Bèrna intelektuālā attistiba (The Construction of Reality in the Child). Meinerte, S. (Transl.) Rīga: Pētergailis. (Original work published 1937).

Purēns, V. (2017). Kā attīstīt radošumu (How to develop creativity). In: Didaktika. Kā attistit kompetenci (Didactics. How to develop competency). Rīga: RaKa.

Ricoeur, P. (1976). Interpretation Theory: Discourse and the Surplus of Meaning. Fort Worth, TX: Texas Christian Univ. Press.

Ricœur, P., \& Thompson, J. B. (2016). Metaphor and the Main Problem of Hermeneutics. In: Hermeneutics and the human sciences. Cambridge, United Kingdom: Cambridge University Press.

Rudzītis, J. (1994). Metodiski materiāli latviešu literatūras skolotājam (Methodical materials for Latvian literature teachers), Vol. 1. Rìga: Izglìtība.

Rudzītis, J. (2000). Literatūras mācỉbas skolā (Literature studies at School). Rīga: RaKa.

Skalbe, K. (1998). Kaķī̌sa dzirnavas (Cat's Mill). In: Duka, V. (Ed.), Pasakas (Children's stories) (pp. 111-124). Rīga: Atēna. (Original work published 1913).

Skalberga, A. (2012). Vidusskolēna literārās kompetences veidošanās (Formation of HighSchool Student's Literary Competence). Doctoral dissertation. Retrieved from https:// dspace.lu.lv/dspace/handle/7/4834.

Smith, T. W. \& Colby, S. A. (2007). Teaching for deep learning. The Clearing House. A Journal of Educational Strategies, Issues and Ideas, 80(5), 205-210. DOI: 10.3200/ TCHS.80.5.205-210.

Šteinberga, A. (2013). Pedagoğiskā psiholog̣ija (Pedagogical psychology). Rīga: RaKa.

Tinjakova, E. A. (2018). Filozofija daet kljuch $k$ mezhdiciniplinarnomu padhodu v izucheniji jazika (Philosophy provides the key to an interdisciplinary approach to language learning). Moskva, Russia: Direkt-Media.

Vidnere, M. (2015). Iztēle: psihologíija un terapija (Imagination: psychology and therapy). Rìga: RaKa.

Ziedonis, I. (1999). Par iedvesmu (On Inspiration). In: Konste, A. (Ed.), Raksti 12 sējumos (pp. 31-36). Rīga: Nordik.

Zulkarnaen, Supardi, Z. A. I., \& Jatmiko, B. (2017). Feasibility of creative exploration, creative elaboration, creative modeling, practice scientific creativity, discussion, reflection (c3pdr) teaching model to improve students' scientific creativity of junior high school. Journal of Baltic Science Education, November 1, 2017, 1020-1034.

Žogla, I. (2001). Didaktikas teorētiskie pamati (Theoretical Basics of Didactics). Rīga: RaKa. 
https://doi.org/10.22364/htqe.2018.14

Jānis Skābardis, Andrejs Gluščuks, Ilvis Ābeḷkalns

FS "Metta”, University of Latvia, Latvia

\title{
ANALYSIS AND USE OF PHYSICAL CHARACTERISTIC TESTS IN THE TRAINING PROCESS FOR FOOTBALL PLAYERS OF DIFFERENT AGES
}

\begin{abstract}
The Objective of the study Analysis and Use of Physical Characteristic Tests in the Training Process for Football Players of Different Ages is to develop the physical characteristic profile of Football School (FS) "Metta" football players based on the data analysis of the applied study, and to assess the practical application towards the improvement of the training process. The authors conducted a study involving $n=61$ football players (boys) in U14 age group, as well as $n=55$ football players in U15 age group and $n=52$ football players in U16 age group. All participants were tested by using a flying $20 \mathrm{~m}$ sprint test, and a modified T agility test and YYIR test (U14 and U15 - $1^{\text {st }}$ level and U16 - $2^{\text {nd }}$ level). U15 FS “Metta" football players are $1.7 \mathrm{~km} / \mathrm{h}$ faster than U14 players and these differences are statistically reliable $(p<0.05)$ with an average effect size $(d=0.94)$. When comparing results obtained from both groups in YYIR1 and T agility tests, the differences are statistically reliable but with a low effect size: $290 \mathrm{~m}(d=0.51)$ and $0.16(d=0.41)$ respectively, in favour of U15. Differences between $\mathrm{U} 15$ and $\mathrm{U} 16$ in the T agility test (turns to rights and left) are statistically reliable $(p<0.05)$ but with low effect size: $0.22(d=0.59)$ and $0.25(d=0.58)$ seconds respectively. U15 football players of FS "Metta," who have been included in the first team, exceed the average indicators in the physical characteristic profiles. In terms of speed, the player is close to the average adult level $(\sim 30 \mathrm{~km} / \mathrm{h})$.
\end{abstract}

Keywords: physical characteristics, football players' profile, physical characteristic test.

\section{Introduction}

The scientific study of football and its training practice dates back to the 1970s (Drust, Green, 2013) when movements of football players in 
various positions were analysed (Reilly, 1976). To improve the performance of football players during competitions, it is necessary to describe the game itself as it stands nowadays according to various parameters: physiological, technical, tactical, physical, etc. Therefore, it is crucial not only to assess the performance of the competition, but also to assess and analyse the training process. It was discovered that the aerobic energy system dominates a player for most of the match. However, the game of football is characterized by various operations at different intervals, and thus the anaerobic energy system is in use more often. During interaction with differing combinations of low, medium, and high intensity football activities, the average oxygen consumption is $70 \%-80 \%$ of the maximum oxygen consumption rate (V02max), and the average heart rate is about $80 \%-90 \%$ of the maximum heart rate HRmax (Bangsbo, Mohr, 2006; Mohr, Krustrup, 2003).

Kraemer and Hakkinen (2002) explain that the ratio for high and low intensity work is $1: 7$. The average blood lactate level is from $2-10 \mathrm{mmol} / \mathrm{l}$, halfway through the final phase (normally, a match is split up into 15 minute intervals), the level increases (Gonçalves, Coutinho, 2017; Bloomfield, Polman, 2007; Bangsbo, Mohr, 2006; Mohr, Krustrup, 2003; Kraemer, Hakkinen, 2002). The data obtained is then used both to solve technical/tactical tasks and develop physical abilities. The used measuring devices (e.g. heart rate monitor, global positioning systems) enable workload dosage according to individual needs and the assessment of its compliance with pre-defined tasks.

The data gathered on a player's individual skills and abilities is crucial when assessing a football player's potential. There is a research (Höner, Leyhr, 2017; Gonaus, Müller, 2012; Unnithan, White, 2012; Gall, Carling, 2010; Williams, Reilly, 2010), for talent identification models, and the abilities and skills of young people are assessed to predict a football player's career opportunities and development directions. Over the course of this assessment process, football players' biomotor abilities, technical skills and other strengths are measured and analysed. The selection of football players, who play on a professional level (have participated in an official game) show better results. However, the assessment of results must also recognize young people whose biological age is behind their chronological age and therefore their development is delayed (Höner, Leyhr, 2017; Gonaus, Müller, 2012; Unnithan, White, 2012; Gall, Carling, 2010; Williams, Reilly, 2010; Reilly, Williams, 2010). Höner and Leyhr (2017) having surveyed 14178 young footballers (from the age of 12), their physical characteristics (speed and agility), as well as elementary footballing parameters, through a long term study concluded that the average effect size $(d=0.70)$ in speed parameters is between those who become professional footballers 
and those who do not reach the professional level. Gall and Carling (2010), working with speed parameters among youth players (U14), who reach a professional level (participating in an official match), as well as amateurs, found that the results were higher for the former, with a low effect size $(d=0.50)$ There is also a contrasting belief stating that it is not possible to use physical parameters to assess a football player's talent (Pankhurst, Collins, 2013; Buchheit, Simpson, 2012; Lidor, Côté, 2011; Franks, Williams, 1999). What is lacking in the testing of physical characteristics, according to Lidor and Côté (2011) is the failure to rate the match understanding components. Testing procedures do not include situational predictions of decision making. In addition, testing is done on an individual basis and does not include the demands of being part of a team game. However, it is possible to use the information acquired about an athlete's physical characteristics in the planning and execution of training. The information can also be adequately presented to the athlete, potentially serving as motivation for the player (Lidor, Côté, 2011).

The objective of the study: to develop the physical characteristic profile of FS "Metta" football players based on the data analysis of the applied study and to assess the practical application thereof to the improvement of the training process.

Study question: How to use physical characteristic testing parameters in order to evaluate the career development of a footballer and to improve training methods?

Within the research project, the authors will employ the biomotor ability test to define a footballer's maximum speed, agility and endurance. They also developed football players' profiles at FS "Metta" for the age group from U14 (people younger than 14) to U16. Furthermore, the obtained information will be used to improve the training process. In the long-term, this database will allow analysis of the gathered data in terms of the developmental direction of the football player's career. Therefore, this will allow the assessment and improvement the current training methods. In the view of Buchheit (2009), explaining a footballer's indicators in $5 \mathrm{~m}, 10 \mathrm{~m}$, and $20 \mathrm{~m}$ sprints, indicators about a players' acceleration are acquired, which gives no practical benefit the the improvement of the training process. However, in examining a footballer's maximum speed and $\mathrm{V}_{\text {YYIRT }}$, it is possible to use these values in the improvement of the training process. Therefore it is possible to adjust individual running speeds during interval training (Buchheit, Simpson, 2002, Buchheit, 2009). 


\section{Research methods}

The physical characteristic assessment protocol of football players includes the following tests: flying $20 \mathrm{~m}$ sprint, $\mathrm{T}$ agility test, Yo-Yo Intermittent Test (YYIRT) $1^{\text {st }}$ (up to U15 age group included) and $2^{\text {nd }}$ level. The physical characteristics are assessed three times per year:

1. On second week after resuming training in January.

2. In June or July, depending on the championship schedule and match dates.

3. After the end of the championship (November).

Test protocol: 20 min warmup, trial run, two attempts of flying $20 \mathrm{~m}$ sprint with at least three minutes of rest in-between the runs, trial run, and a $\mathrm{T}$ agility test with one attempt on the right side and one attempt on the left side. Both "Microgate Witty Wireless Training Timer" system to record time results. YYIR test is performed after the speed and agility tests. The testing results are registered with "Bitworks Team Beep Test" programme which also includes playing of an audio recording.

The average sprint/acceleration distance covered by players in team sports is $\sim 20 \mathrm{~m}$ and the start position takes place in movement (Brown, Vescovi 2012; Mohr, Krustrup, 2003). The maximum speed is reached in 20-30 m (Vescovi, Rupf, 2010). Based on the pre-defined information as to reaching the maximum speed, the authors used flying $20 \mathrm{~m}$ sprint with $25 \mathrm{~m}$ of run-up. The maximum speed is calculated.

The authors had previously learned from the football analysis sources that a player's manoeuvrability (agility) is an important aspect in football. The authors selected the $\mathrm{T}$ agility test as their core approach (Semenick, 1990), applying certain modifications (see Figure 1) so that the realization process would be as practical as possible (adopted from the Nike Football Academy, 2014). Unlike the initial test version, the type of movement is no longer regulated.

The game of football includes a certain regiment of intervals (e.g. slow or moderate intensity runs, sprints, jumps, stops) (Bloomfield, Polman, 2007; Bangsbo, Mohr, 2006; Mohr, Krustrup, 2003; Kraemer, Hakkinen, 2002). Therefore, to determine the football players' endurance (ability to recover in-between intensive outbursts, as well as the speed at which the participant comes to a stop $-\mathrm{V}_{\text {YYIRT }}$ ) the authors employed the YYIR test (Bangsbo, Iaia, 2008). The obtained $\mathrm{V}_{\text {YYIRT }}$ results can be used in the training process to develop interval exercises as close as possible to the maximum speed of oxygen uptake (vVO2max). When interpreting the obtained results, it must be remembered that $\mathrm{V}_{\text {YYIRT }}$ is lower than vVO2max and thus it must be considered when planning the training workloads (Buchheit, 2009). The $1^{\text {st }}$ level test which starts with $10 \mathrm{~km} / \mathrm{h}$ interval is performed by U14-U15 


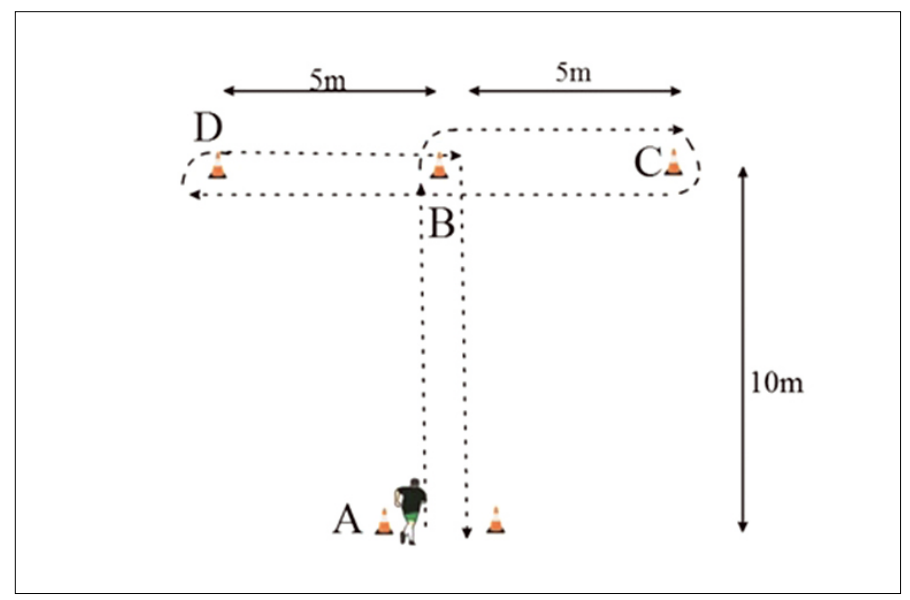

Figure 1. Nike Academy modification of the T agility test (adopted from the Nike Football Academy, 2014)

(included) age groups. The $2^{\text {nd }}$ level test which starts with $13 \mathrm{~km} / \mathrm{h}$ interval is performed by U16 and older athletes.

The Microsoft Excel program was used for statistical analysis. The obtained results were processed by the use of descriptive statistics. In order to develop the football players' profile in each age group, the authors used \pm standard deviation of average arithmetic values. When comparing the groups among themselves, the authors used student $t$ value for independent groups with the significance level $p<0.05$. Such methodology was employed because each age group had different methods as well as different composition of participants. Furthermore, each age group had its own coach. Therefore, age groups must be assessed as not connected. To determine the effect size of differences between the groups, we are to use the model developed by Hopkins W. G. (2010) according to which there is trivial $(d<0.2)$, low $(0.2<d<0.6)$, average $(0.6<d<1.2)$, high $(1.2<d<2.0)$ and very high $(2.0<d<4.0)$ level of significance.

\section{Results}

To develop FS “Metta" football players' profile, U14 group includes $n=61$ players. The total number of measurements in flying $20 \mathrm{~m}$ sprint and maximum speed -124 , YYIR test -120 and T agility test - 126. U15 group includes $n=55$ players. The total number of measurements in flying $20 \mathrm{~m}$ sprint and maximum speed - 116, YYIR test -106 and T agility test -111 . U16 group includes $n=52$ players. The total number of measurements in flying 20m sprint and maximum speed - 91, YYIR test - 79 and T agility test -87 . The results are not grouped according to player positions. 
Table 1. FS “Metta" football players' profile in respective age groups

\begin{tabular}{|c|c|c|c|c|c|}
\hline \multirow{2}{*}{$\begin{array}{c}\text { Age } \\
\text { group }\end{array}$} & $\begin{array}{c}\text { Plying 20 m } \\
\text { sprint, sec }\end{array}$ & $\begin{array}{c}\text { Max speed, } \\
\mathbf{k m} / \mathbf{h}\end{array}$ & $\begin{array}{c}\text { YYIRT, } \\
\mathbf{m}\end{array}$ & $\begin{array}{c}\text { T agility on } \\
\text { the right } \\
\text { side, } \\
\text { sec }\end{array}$ & $\begin{array}{c}\text { T agility on } \\
\text { the left side, } \\
\text { sec }\end{array}$ \\
\hline U14 & $2.65 \pm 0.16$ & $27.2 \pm 1.7$ & $\begin{array}{c}\text { YYIRT1 } \\
1170 \pm 516\end{array}$ & $9.85 \pm 0.40$ & $9.81 \pm 0.36$ \\
\hline & & & $\begin{array}{c}\text { YYIRT1 } \\
1460 \pm 652\end{array}$ & $9.69 \pm 0.38$ & $9.69 \pm 0.41$ \\
\hline U15 & $2.50 \pm 0.18$ & $28.97 \pm 2.05$ & YYIRT2 & & \\
U16 & $2.46 \pm 0.14$ & $29.4 \pm 1.7$ & $636 \pm 279$ & $9.48 \pm 0.34$ & $9.47 \pm 0.35$ \\
\hline
\end{tabular}

When comparing U14 and U15 age groups, the authors found out that the differences in flying $20 \mathrm{~m}$ sprint and subsequently the maximum speed were statistically reliable $(p<0.05)$ with average significance $(d=0.94)$. U15 football players are $0.15 \mathrm{sec}(1.7 \mathrm{~km} / \mathrm{h})$ faster than U14 football players (see Table 1). The differences between the age groups in the YYIR 1 test and the T agility test with turning to right are statistically reliable $(p<0.05)$ but with low level of significance: $290 \mathrm{~m}(d=0.51)$ and $0.16 \mathrm{sec}(d=0.41)$ in favour of U15. In terms of turning to left, the difference is statistically reliable. There is information suggesting that differences between the levels of different players cannot be observed in isolated agility actions. This can only be observed when the test also addresses the decision making-process in the context of football. The $\mathrm{T}$ agility test does not address this aspect (Trecroci, Milanović, 2018).

The comparison between U15 and U16 speed characteristics shows that the difference between both groups is neither significant nor statistically reliable. The endurance tests were not compared because execution was different. U16 football players were faster in the $\mathrm{T}$ agility tests in both right and left turns: 0.22 and $0.25 \mathrm{sec}$ respectively. These differences are statistically reliable $(p<0.05)$ with low level of significance $(d=0.59$, $d=0.58)$.

\section{Discussion}

When assessing the results from all of the work done in this study, it must be noted that measurements are taken without the context of football. As indicated by Trecroci and Milanovič (2018) having observed U15 footballers' agility, there is no difference between elites and average level footballers. Although the $\mathrm{T}$ agility test results characterize a football player's ability to accelerate speed and swiftly stop and change direction, it 
must be noted that the test is carried out without the context of a football game (decision-making) (Trecroci, Milanović, 2018).

Therefore, these results must be seen in conjunction with the performance in a football game in order to obtain even more accurate measurements for the football player's profile. In further studies, it is necessary to develop measurement/indicator methods with included assessment for understanding of football.

Physical characteristic differences can be seen in the transition from U14 to U15. It is possibly related to the rapid growth period (Fernāte, 2018). Furthermore, FS "Metta" training methodology employs specialized and football-related speed and endurance exercises starting from U15 age group. From U15 to U16, the physical characteristics differ in terms of agility. This could be explained by the fact that within a year after the rapid growth period (Fernāte, 2008) the body has adapted and thus the football player is more capable of controlling his own body in turns, accelerations and direction changes. The maximum speed once again improves from U16 to U17; however, to gain confirmation for the aforementioned statement, it is necessary to increase the data volume for the U17 age group.

The physical characteristics of FS "Metta" players (starting from U15 age group) who have played in an adult team are above the average profile of football players (maximum speed $=28.97 \pm 2.05 \mathrm{~km} / \mathrm{h}$, YYIR1 test $=1460 \pm 652 \mathrm{~m}, \mathrm{~T}$ agility test to right and left $=9.69 \pm 0.38$, $9.69 \pm 0.41 \mathrm{sec})$ and their speed results reach the elite level norms of adults ( $>30 \mathrm{~km} / \mathrm{h}$ ) (Andrzejewski, Chmura, 2015; Bangsbo, Mohr, 2006). Further studies are required to learn what level of athleticism is reached by football players with the respective results and whether these results are decisive to become a professional football player.

\section{Conclusions}

Based on the study's theoretical part, the authors conclude that the obtained information will improve the training process through forming groups with equal speed or durability characteristics, thus customizing a football player's training plan. The results obtained were used to develop football players' physical characteristic profiles (see Table 1), e.g.: U16 FS "Metta" football player can reach $29.4 \pm 1.7 \mathrm{~km} / \mathrm{h}$; in the same profile, the YYIR2 test results show $636 \pm 279 \mathrm{~m}$, where the $\mathrm{V}_{\text {YYIR2T }}=17.5 \pm$ $0.5 \mathrm{~km} / \mathrm{h}$, but the $\mathrm{T}$ agility test results show $9.48 \pm 0.34 \mathrm{sec}, 9.47 \pm$ $0.35 \mathrm{sec}$ in turns to right and left respectively. This gives a representation of FS "Metta" students (U14-U16) in the period from 2016 to 2018. The information acquired will allow the understanding of which parameters are necessary to reach the level of Latvian competition, foreign competition, 
or to remain at the amateur level. Upon gathering information about FS "Metta" students who have played professionally (played on the field in an adult game), it can be concluded that the adult level is reached by the players who exceed physical characteristics of U15 age group profile. However, it is still necessary to extend the data to clarify the desirable thresholds. Further studies on the same topic require introduction of results of understanding the game of football, as well as assessment of development of the football player's career after the age of 18, 21 and 25.

\section{References}

Andrzejewski, M., Chmura, J., Pluta, B., \& Konarski, J. (2015). Sprinting Activities and Distance Covered by Top Level Europa League Soccer Players. International Journal of Sports Science and Coaching, 10, 39-50. DOI: 10.1260/1747-9541.10.1.39.

Bangsbo, J., Iaia, F. M., \& Krustrup, P. (2008). The Yo-Yo intermittent recovery test: a useful tool for evaluation of physical performance in intermittent sports. Sports Med., 38(1), 37-51. Review. PubMed PMID: 18081366.

Bangsbo, J., Mohr, M., \& Krustrup, P. (2006). Physical and metabolic demands of training and match-play in the elite football player. Journal of Sports Sciences. Jul, 24(7), 665-74. Review. PubMed PMID: 16766496.

Bloomfield, J., Polman, R., \& O’Donoghue, P. (2007). Physical Demands of Different Positions in FA Premier League Soccer. Journal of Sports Sciences Med, 6(1), 63-70. eCollection. PubMed PMID: 24149226; PubMed Central PMCID: PMC3778701.

Brown, T. D. \& Vescovi, J. D. (2012) Maximum Speed: Misconceptions of Sprinting. Strength and Conditioning Journal, 34(2), 37-41. DOI: 10.1519/SSC.0b013e31824ea156.

Buchheit, M. (2009). The 30-15 Intermittent Fitness Test: 10 year review. Myorobie Journal, 1.

Buchheit, M., Simpson, B., Peltola, E., Mendez-Villanueva, A. (2012). Assessing Maximal Sprinting Speed in Highly Trained Young Soccer Players. International Journal of Sports Physiology and Performance, 7, 76-8. DOI: 10.1123/ijspp.7.1.76.

Drust, B., \& Green, M. (2013). Science and football: evaluating the influence of science on performance. Journal of Sports Sciences, 31(13), 1377-1382, DOI: $10.1080 / 02640414.2013 .828544$.

Fernāte, A. (2008) Vispusība - galvenais princips bērnu un jauniešu sportā. No: Bērnu un Pusaudžu Trenera Rokasgrāmata (Comprehensiveness - the main principles of youth and adolescent sports). Latvijas treneru tālākizglītības centrs. Rīga, p. 41.

Franks, A. M., Williams, A. M., Reilly, T., Nevill, A. (1999). Talent identification in elite youth soccer players: Physical and physiological characteristics. Communication to the $4^{\text {th }}$ World Congress on Science and Football, Sydney. Journal of Sports Sciences, 17, 812.

Gonaus, C., \& Müller, E. (2012). Using physiological data to predict future career progression in 14- to 17-year-old Austrian soccer academy players. Journal of Sports Sciences, 30(15). DOI: 10.1080/02640414.2012.713980.

Gonçalves, B., Coutinho, D., Santos, S., Lago-Penas, C., Jiménez, S., \& Sampaio, J. (2017). Exploring Team Passing Networks and Player Movement Dynamics in Youth Association Football. PLOS ONE, 12(1), e0171156. Retrieved from http://doi.org/10.1371/journal. pone.0171156. 
Höner, O., Leyhr, D., \& Kelava, A. (2017). The influence of speed abilities and technical skills in early adolescence on adult success in soccer: A long-term prospective analysis using ANOVA and SEM approaches. PLOS ONE, 12(8), e0182211. Retrieved from http:// doi.org/10.1371/journal.pone.0182211.

Hopkins W. G. (2010). Linear models and effect magnitudes for research, clinical and practical applications. Sportscience. 14. Retrieved from sportsci.org/2010/wghlinmod. htm; accessed on 10.02.2013.

Kraemer, J. W., \& Hakkinen, K. (2002). Strength Ttraining For Sport. Blackwel Science, pp. 75-91.

Le Gall, F., Carling, C., Williams, M., \& Reilly, T. (2010). Anthropometric and fitness characteristics of international, professional and amateur male graduate soccer players from an elite youth academy. $J$ Sci Med Sport, 13(1), 90-95. DOI: 10.1016/j. jsams.2008.07.004. Epub 2008 Oct 2. PubMed PMID: 18835220.

Lidor, R., Côté, J., \& Hackfort, D. (2011). ISSP position stand: To test or not to test? The use of physical skill tests in talent detection and in early phases of sport development. Int J Sport Exerc Psychol, 9. DOI: 10.1080/1612197X.2009.9671896.

Mohr, M., Krustrup, P., \& Bangsbo, J. (2003). Match performance of high-standard soccer players with special reference to development of fatigue. Journal of Sports Sciences, 21(7), 519-28. PubMed PMID: 12848386.

Mohr, M., Krustrup, P., \& Bangsbo, J. (2003). Match performance of high-standard soccer players with special reference to development of fatigue. Journal of Sports Sciences, 21, 519-528.

Nike Football Academy. (2014). Retrieved from https://www.nike.com/academy/ training/index.html.

Pankhurst, A., \& Collins, D. (2013). Talent identification and development: The need for coherence between research, system, and process. Quest, 65(1), 83-97. Retrieved from https://doi.org/10.1080/00336297.2012. 727374.

Reilly, T., \& Thomas, V. (1976). A motion analysis of work-rate in different positional roles in professional football match-play. Journal of Human Movement Studies, 2, 87-89.

Reilly, T., Williams, A. M., Nevill, A., \& Franks, A. (2010). A multidisciplinary approach to talent identification in soccer. Journal of Sports Sciences, 18(9), 695-702. DOI: 10.1080/02640410050120078.

Semenick, D. (1990) Tests and measurements: The T-test. NSCA J. 12(1), 36-37.

Trecroci, A., Milanović, Z., Frontini, M., Iaia, F. M., \& Alberti, G. (2018). Physical Performance Comparison between Under 15 Elite and Sub-Elite Soccer Players. Journal of Human Kinetics, 61, 209-216. Retrieved from http://doi.org/10.1515/hukin-2017-0126.

Unnithan, V., White, J., Georgiou, A., Iga, J., \& Drust, B. (2012). Talent identification in youth soccer. Journal of Sports Sciences, 30(15), 1719-26. DOI: $10.1080 / 02640414.2012 .731515$.

Vescovi, J. D., Rupf, R., Brown, T. D., \& Marques, M. C. (2010) Physical performance characteristics of high-level female soccerplayers 12-21 years of age. Scandinavian Journal of Medicine and Science in Sports, 11(11).

Williams, A. M., \& Reilly, T. (2010) Talent identification and development in soccer. Journal of Sports Sciences, 18(9), 657-667. DOI: 10.1080/02640410050120041. 


\title{
CONTRIBUTION OF ORCHESTRA CONDUCTORS TO DEVELOPMENT OF LATVIAN SYMPHONY ORCHESTRA CONDUCTING SCHOOL SINCE THE BEGINNING OF THE $20^{\text {TH }}$ CENTURY AND UNTIL THE END OF THE WORLD WAR II
}

\begin{abstract}
The article "Contribution of orchestra conductors to development of Latvian symphony orchestra conducting school since the beginning of the $20^{\text {th }}$ century and until the end of the World War II" characterises the personalities of the conductors Artūrs Bobkovics, Emīls Kupers, Georg Schneevoigt, Teodors Reiters, Jānis Kalniṇš, Jānis Mediṇš, Oḷǵerts Bištēvin,š, Bruno Skulte and Ādolfs Ābele, who played a significant role in development and inheriting of the traditions of symphony orchestra conducting in Latvia, as well as in interaction of art of conducting and composition, along with promotion of interaction with the world music culture traditions. The outstanding artistic activities of the aforementioned conductors may be viewed as a substantial precondition for the formation of the Latvian symphony orchestra conducting school in the period from the beginning of the $20^{\text {th }}$ century and until the end of World WII.
\end{abstract}

Keywords: conducting school, personality, conductor, traditions, development of principles, symphony orchestra.

The purpose of the study: To evaluate the contribution of the foremost conductors in the earliest stage of the formation of the Latvian symphony orchestra conducting school.

The concept of the principles of a national conducting school as a certain aesthetic direction, the essence and purpose of which is the acquisition of views and traditions, their preservation and dissemination is based on the principles of modern art education as defined by Jānis Anspaks (Anspaks, 
2006(a)). The national conducting school is a direction in the music culture, based on a set of certain artistic aesthetic principles, culture traditions and experience, and, as said above, its basic tasks acquisition, preservation, elaboration and dissemination of these values.

Exceptional personalities in the art of conducting are a precondition for the formation of the national symphony orchestra conducting school, therefore it is important to assess the contribution of outstanding conductors in the Latvian music culture.

- the age: "An age sets the requirements for a personality, marks the ways of Latvian, while the personality with one's creative, purposeful actions influences the direction of the society";

- pedagogy: “... having performed significant research, enriched such areas of pedagogy science as pedagogy history, psychological pedagogy, methodology";

- ideas and conclusions "... based on the results of a research";

- the essence of a personality, revealed in "... action, achievement, or in a wider sense - in the life achievement, lifeworld" (Krūze, 2008, pp. 4-5).

Another aspect characterising personality and its greatness, is revealed in the statement of $\mathrm{J}$. Anspaks, that in preservation and Latvian of culture values the activity of every individual - self-education - plays a great role (Anspaks, 2006).

A. Maslow, characterising the structure of a creative personality, attaches great significance to relation of a creative personality and its self-actualization. Maslow connects the self-actualisation with such traits of a creative personality as openness to emotional experience, natural and free behaviour, naivety in perception and ways of expression, strive for that what is beyond the grasp of the human mind, lack of fear. Such human activity is characterised by structured cognition, mind governed by intuition (Maslow, 1987).

In study of personality also the following needs to be emphasised:

- social relationships characterising a personality - "(..) a personality is a human being having entered into certain social relationships, being aware of these relationships and as a subject of active action can change the world and be responsible for the results of this change." (Karpova, 1998, p. 13);

- a personality having (..) a certain scale of influence, that can be calculated from a territorial perspective (..). Influence can also be measured in generations and number of contemporaries and descendants covered by the ideas and emotions (..)." (Karpova, 2005, p. 10). 
Assessment of the ideas by A. Dauge, J. Anspaks, Ā. Karpova, A. Krūze was the conclusive factor in selection of the personalities, in order to characterise their contribution in development of Latvian symphony orchestra conducting school. For the present research those personalities conductors significant for the Latvian and existence of the Latvian symphony orchestra conducting school - were chosen whose lifework shows the following:

- self-actualisation as the most substantial element in the characterisation of a creative personality (A. Maslow);

- self-perfection and self-education (A. Dauge, J. Anspaks);

- the scale of a personality's influence that can be evaluated in a certain territory and whose influence can be felt in several generations (A. Karpova);

- individual peculiarities, unique individual features, individual style (A. Karpova);

- teaching activities.

- the evaluation of conductors' contribution was based on the elements characterising the formation, existence and development of the Latvian symphony orchestra conducting school, and namely: contribution in popularisation of the Latvian national composition school that promoted the inclusion of folk traditions, norms and values in the symphony orchestra music culture;

- contribution in the establishment or work of the conservatory that contributed to teaching of new professional symphony orchestra conductors;

- relationship with the choir music culture traditions that to a great extent promoted the formation of orchestra conducting traditions;

- rich experience in direction of professional ensembles, orchestras, musical theatres and choirs;

- openness towards other musical cultures and contribution to the world musical culture.

The activity of individual conductors reflects significant elements characterising the formation, existence and development of the Latvian symphony orchestra conducting school, as a talented performer can in any circumstances surprise and inspire the audience with a fresh, original and unique interpretation of the performed piece that leaves an impression on the public opinion. The basis of this phenomenon is the personality of the artist, as defined by his value orientation and inimitable individuality (Karpova, 1994) that substantially influences the performance of the musical piece, as the development of performing art is closely related to the development of individual personalities. 


\section{Artūrs Bobkovics}

(1885-1959)

Artūrs Bobkovics was not only the first professionally educated Latvian symphony orchestra conductor, but also a teacher and the long-term director of Latvian University choir. ${ }^{1}$ His importance is also increased by the fact that Bobkovics was the founder of the Latvian University chamber orchestra. Thus in his lifework he has realised himself in the fields, that have also been of importance for the activities of other Latvian symphony orchestra conductors.

In his day neither Moscow, nor Petersburg conservatories had special conductors departments, also in Germany at the beginning of the $20^{\text {th }}$ century there were only two such departments - in Leipzig and Sondershausen. From this it may be concluded that G. Schneevoigt urged A. Bobkovics to choose Sondershausen as his university, as at the beginning of 1903 A. Bobkovics entered Leipzig conservatory, but moved to Sondershausen the autumn of the same year, becoming the student of K. Schroeder ${ }^{2}$, who also were the conducting teacher of G. Schneevoigt.

On 4 January, 1907 in the grand hall of the Latvian Society Artūrs Bobkovics on his own responsibility and his material contribution organised a symphony concert with the orchestra of the Riga's German Theatre (Opera). This extraordinary fact initiated a new era in the history of Latvian musical culture, as also in the coming years, despite different obstacles, A. Bobkovics organised 4-6 symphony concerts each winter seasons (Jaugiets, 1970).

"Bobkovics' conducting was so convincing, that even musically less sophisticated members of the audience immediately instinctively felt that they are observing a true talent" (Dārziņš, 1975, 121-122).

A great merit of Artūrs Bobkovics is also the fact that in these regular symphony concerts he included not only the works by the music classics (L. Beethoven, F. Liszt, R. Schumann, R. Wagner, K. M. Weber, P. Tchaikovsky) but also by Latvian composers (E. Dārziņš, A. Kalniņ̌s, J. Vìtols), premiering many of those (Jaugiets, 1970).

The contribution of Artūrs Bobkovics to development of Latvian symphony orchestra conducting traditions and education of concert audiences is undeniable, as testified by his regularly organised concerts, but the fact that A. Bobkovics turned to choir conducting emphasises a peculiarity characteristic not only to the Latvian situation - connection of symphony orchestra conductors with choir conducting.

\footnotetext{
${ }^{1}$ Artūrs Bobkovics//Skolotāja lieta. LVVA, 1632. f., 1. apr., 2606. l., p. 7.

${ }^{2}$ Turpat, p. 11.
} 
In relation to activities of $\mathrm{A}$. Bobkovics another aspect characteristic to work Latvian symphony orchestra conductors becomes obvious, namely - rivalry.

\section{Emil Kuper}

(1877-1960)

"A new life to the life of symphony music in Riga was brought by the conductor E. Kuper" (Kārklinšs, 1990, 78). Anatoliy Kuznetsov, the author of the introduction to a book about Emil Kuper counts E. Kuper as a representative of the Russian conducting school: "The name of E Kuper is inscribed in the history of the Russian conducting school" (Купер, 1988, p. 7), allowing to conclude that during his time of activity in Riga from the end of 1925 until the end of 1928, Emil Kuper brought the best traditions of the Russian music culture into the Latvia's music life. His importance for the Latvian symphony orchestra conducting school formation process is also increased by the fact that on the invitation of Jāzeps Vittols in the academic year 1927/1928 the Latvian Conservatory opened the Conductors' class under Kuper's leadership ${ }^{3}$. Emil Kuper led the class for less than three seasons, and the following conductors were among his students: Viktors Babins, Jānis Norvilis, Voldemars Ozoliņš, Juozas (Jazeps) Karosas, Jēkabs Vītolinš, Alfrēds Feils, Austra Šiller, Helmers Pavasars, Vladislavs Jakubenas, Volfgangs Dārzin̄šs, Arturs Sīlis ${ }^{4}$. Leonīds Vīgners must be mentioned as one of the best among Kuper's students, as testified by the records of E. Kuper's conducting class available at the Latvian State Archive found journals. ${ }^{5}$

The most important contribution of Emil Kuper to the development of the Latvian symphony orchestra conducting school is as follows:

- being the first teacher of the newly founded Latvian Conservatory Conducting class;

- enrichment of Latvian symphony orchestra conducting traditions with the experience of Russian and German conducting traditions;

- raising the artistic level of the performances of the Latvian National Opera.

\footnotetext{
${ }^{3}$ Latvijas Konservatorija // Emils Kupers. LVA, 1655. f., 1. apr., 66. l. 1. lp.

${ }^{4}$ Latvijas Konservatorija // Spec. pr. Dirigenta E. Kupera k-ga klase 1926./27. m. g. LVA, 1655. f., 1. apr., 720. l., p. 1.

${ }^{5}$ Latvijas Konservatorija // Spec. pr. Diriǵenta E. Kupera k-ga klase 1927./28. m. g. LVA, 1655. f., 1. apr., 721. l., pp. 1.-5.
} 


\section{Georg Schneevoigt}

(1872-1947)

Georg Schneevoigt was an important personality in the formation process of the Latvian conducting traditions. Being a Finnish conductor, he had periodic ties with the Latvian music life for more than a quarter of a century.

"The concert organised by the orchestra of the German Theatre under the leadership of the conductor Mr. Schneevoigt was equally excellent in regard to its content as it was in regard to the performance" ( Dārziņš, 1975, 228).

"Also the Latvian conductors (Bobkovics) should thank him for education and friendly attitude" (Sudrabkalns, 1926).

In the seasons of 1929/30 and 1930/31 the work of Georg Schneevoigta in Riga is of great importance both for the National Opera, as he was the main guest conductor of it, and the Latvian Conservatory, where he continues the work started by Emil Kuper, for two years being the Head of the Conducting class and also the Orchestra class. ${ }^{6}$ The following conductors were his students: Arnolds Lapiņšs, Rudolfs Krippe, Kārlis Lietiņš, Jānis Ivanovs, Arturs Sīlis, Mārtiņš Jansons, ${ }^{7}$ Oḷgerts Bištēviṇš, Jānis Norvilis, Volfgangs Dārziņ̃̌ and Leonīds Vīgners. ${ }^{8}$

The most important contribution of Georg Schneevoigt to the development of the Latvian symphony orchestra conducting school is as follows:

- enrichment of the Latvian symphony orchestra conducting traditions with the experience of the German conducting traditions;

- teaching work a the Conducting class of the Latvian Conservatory and support provided for the younger Latvian colleagues, as well as promotion of education;

- during the second half of his artist's life he undertook the popularisation of the values of Latvian national music.

\section{Teodors Reiters}

(1884-1956)

From August of 1918 and until October 1944 T. Reiters held the position of the leading conductor and for several times - also the director of the National Opera. He was the producer and conductor of numerous operas, and symphonic music concerts. His work in the field of the choral music

${ }^{6}$ Latvijas Konservatorija // Šnēfogts Georgs. LVA, 1655. f., 1. apr., 116. l. p. 1.

${ }^{7}$ Latvijas Konservatorija // Spec. pr. Diriğenta Šnēfogta klase 1929./30. m. g. LVA, 1655. f., 1. apr., 724. l. pp. 1.-5.

${ }^{8}$ Latvijas Konservatorija // Spec. pr. Diriǵenta Šnēfogta klase 1930./31. m. g. LVA, 1655. f., 1. apr., 725. l. pp. 1.-5. 
deserves the highest appraisal, as also his talent is the best demonstrated in this field. "Obviously the true element of T. Reiters was choral music and interpretations of large format oratorial works" (Kārkliņš, 1990, 71).

It deserves a special mention that during his career as an opera conductor Reiters has worked along not only outstanding Latvian conductors - Jānis Mediņ̌s, Jānis Kalniņš, Leonīds Vīgners - but also exceptional foreign masters of conducting - Emil Kuper, Grzegorz Fitelberg, Richard Hagel, the patriarch of the Russian conducting school Nikolai Malko, Lovro von Matačič, Ignaz Waghalter, the exceptional Leo Blech and the majestic Hermann Abendroth.

The most important achievement of Teodors Reiters' life is the foundation of the Latvian National Opera and active work in the position of its conductor, for several times holding not only the position of the chief conductor, but also its director. Along with this direction of his activities the foundation of the Reiters' choir with its exceptionally high artistic level is of no less importance.

The activities of Teodors Reiters display the following aspects of formation of the Latvian national conducting school:

- inclusion of Latvian music in the repertory and its popularisation abroad;

- inclusion in the repertory of large form works, thus indicating the quality of national symphony conducting traditions;

- foundation of a professional Latvian opera music theatre;

- ties with the choral conducting, allowing to popularise the works by Latvian composers abroad, gaining success internationally, promoting the interaction of the Latvian music culture with the art of the world.

\section{Jānis Kalniṇš}

(1904-2000)

Jānis Kalniņš became a conductor at an early age - when he was only 19, he became the head of the Music Department of the National Theatre replacing gin the position his own father - Alfrēds Kalniņš. After ten years of work at the National theatre J. Kalniņš received a proposal to become one of the conductors of the National Opera.

There are testimonies of the fact that in 1979 during the Sixth Song Festival in Garezers (USA) Jānis Kalniņš has been commenting conducting skills and lectured on the topic (Kalns, 2004). According to the aforementioned author, J. Kalniņš considered the following as the basis of conductor's technique development:

- good musical education; 
- developed musical hearing;

- relax musculature and strong, expressive gestures.

J. Kalniņš considered the plasticity of conductor's gestures as especially important, as it is clearly illustrated by the following quote: "There are conductors with stiff movements, spasmodic-looking arms and shoulders. Imagine such a miserable person conducting Aida, Otello or the operas of The Ring of the Nibelungs, or just any other large format opera. He would be carried away to a hospital or even the crematorium already after the Act 1 ! I had such a colleague in Riga, younger than me. I gave him an advice to learn relaxing his body at the dance studio of one of his relatives. He obviously did not take my advice, as - despite his studies in Germany - the literally appallingly lame movements of his arms and the whole body could only repulse, not inspire, not be understood or enjoyed. And this was tolerated and suffered by choirs, orchestras and the audiences. And this musician had the absolute musical hearing and good education." (Kalns, 2004, p. 349).

Evaluating the life activity of Jānis Kalniņš, the following is believed to be his most important contribution to the development of the Latvian symphony and opera conducting school:

- the expressive composing style, that furthered the interaction of traditions of conducting and art of composition;

- ties with the choir conducting processes (being song festival chief conductor in Canada and the USA);

- forming one's own individual methodological ideas regarding the most substantial conditions of conducting technique development;

- originality of his personality, serving as a proof of the role of extraordinary personalities in the art of composition and conducting.

\section{Jānis Mediṇš}

(1890-1966)

Ingrīda Zemzare in her introduction to the book "Toni un pustonii" (Mediņš, 1992) and A. Kalns (Kalns, 2004) express the same idea that Jānis Medins, despite the fact that he was an autodidact in conducting, displayed remarkable ability in this field. His activities as a conductor at the early stages of the National Opera, but also later, being the leader of the Symphony Orchestra of the Radio has received favourable reviews from numerous music critics. The practical work with a symphony orchestra in the capacity of a conductor has been favourable for the advancement of the composer's creative activity (Kārkliņš, 1990).

Regarding the beginning of his conductor's career at the National Opera, Medin̄š writes: "Now I needed just more practice. Without practice a conductor is good for nothing. The students, graduating from the 
conductors class of the Conservatory only become real conductors after a period of practice. These graduates of the conductors class may believe that that they are fully prepared artists, but they are miles away from such a stage, and God forbid such a newbie to come to stand in front of a good orchestra! Then the musicians, as they say, "play pranks on them", that is, they try to play some wrong notes. When the young conductor fails to notice, then he is done, he loses all respect." (Mediņš, 1992, p. 120).

The quote clearly shows the idea expressed in the analysis of the formation of conductor's competencies, namely, that the only way to become a conductor is by practically working with an orchestra. Any previous learning and study experience is just an intermediary stage on the way to the heights of the art of conducting.

"One must return again to Kuper and repeat that I am grateful to him still today. By following his work at rehearsals I was able to learn much more than a any Conservatory. It was a direct, useful practice, not some dry teachings and theories." (Mediňš, 1992, p. 122).

These quotes by J. Medinšs also emphasise one of the basic principles of conducting technique formation - necessity for the conductor to improve his knowledge, skills and abilities constantly.

Already then Medinš understood the essence substantial for the teaching process still today: "My work with the students of the Conservatory was very interesting. It was also useful for myself. I was still young then. There were questions asked by the students, and they made me think. I encountered problems that needed to be solved on the spot and without any delay. Thus, by teaching others, I learned something myself." (Medin̄š, 1992, p. 156).

This proves that already then Medinš had understood the interrelation between the teacher and the student which is of such great importance for the teaching process. Mediņš assigned great importance to self-education in the study process. For example, he suggested his students to study scores. "But I have to admit time and again that it is impossible to learn the skills of instrumentation from theories and textbooks alone. The best schooling in this always be the study of scores." (Mediňš, 1992, p. 157).

"Leading the Conducting Class at the Latvian Conservatory was not a pleasant position. Conservatory Orchestra has always been small and always with something like accidental character to it. Our instrumentalists-to-be excused themselves with lack of time, and in other ways, but the truth was that they had no interest in participation in the Conservatory Orchestra. To force them to attend the Orchestra class was completely beyond my ability. When there is no will, no compulsion can help." (Mediñš, 1992, pp. 157-158). This last sentence very clearly indicates that will is the trait of character primarily necessary in order to become a conductor. 
As the result of the study along the lines of the research topic formulated above the most important contribution of Jānis Medinšs to the development of the Latvian symphony orchestra conducting school is the following:

- the composer's talent, which through popularisation of Latvian symphonic music abroad promoted its interaction with traditions of the world conducting art;

- the extraordinary conductor's talent, that contributed to the popularisation of the Latvian conducting traditions abroad;

- professional leadership of the Latvian Radio Symphony Orchestra over the period of more than fifteen years;

- the work as conducting and instrumentation teacher at the Latvian Conservatory, that resulted in the continuity of the Latvian conducting traditions (Bruno Skulte, Jānis Ivanovs, Jānis Kepītis, Valentīns Utkins).

\section{Oḷǵerts Bištēviṇš}

(1907-1972)

Oḷgerts Bištēviņš is an interesting and outstanding personality among the most recognisable representatives of the Latvian conducting school. The musicologist Ludvigs Kārklinš, in his study of symphonic music creation and performance processes in Latvia, expresses the idea that the creation of symphonic music was promoted by the practical work of composers in the capacity of conductors of symphony orchestras (Kārkliņš, 1990).

This idea appears quite well based, as O. Bištēviņš started his work as a conductor with the performance of his own work "Orkestra dziesma".

The most recognisable conductors, active in the period from the beginning of the $20^{\text {th }}$ century and until 1944 in Latvia, either had acquired education in composition or were prolific authors. Of conductors active in the aforementioned period and studied only Artūrs Bobkovics did not have any education in composition. This is to a great extent the result of the condition that at the end of 1920s and in 1930s only students having already acquired the basics of composition were allowed to enter the Conducting class.

\section{Bruno Skulte}

(1905-1976)

Was known not only as a composer but also a conductor, pianist and organist. At the end of 1930s he was the conductor of the Radio Symphony Orchestra, later also worked as a conductor of the Liepāja Opera orchestra. The concerts conducted by him quite often became outstanding events 
for the music scene of the pre-WWII Latvia (Kārkliņš, 1990). During World War II Bruno Skulte received high public acclaim for the excellent premiere of the IV symphony by Jānis Ivanovs "Atlantīda" (1943) as well as performances of other musical works. (Grāvītis, 2009).

\section{Ādolfs Ābele}

(1889-1967)

When conscripted into the Russian army he soon found place in the music company of the $4^{\text {th }}$ Vidzeme Latvian infantry regiment, where he became the commander of the regiment's brass orchestra shortly after. This may have been the reason why Jāzeps Vìtols invited Ādolfs Ābele to become the teacher of army orchestra conductors at the Latvian Conservatory. $\bar{A}$. Âbele starts his work at the Conservatory as the youngest head of a special - theory class beginning with the 1st September, $1924 .{ }^{9}$ For twenty years Äbele is the teacher of military bandmasters - who were the leading brass band conductors of the time. (Grāvitis, 2009). This is also a kind of paradox, as neither in 1920s and 1930s, nor later in the exile while in Germany and USA he had practically no connection to the orchestra conducting.

\section{Conclusions}

The present study reflects the contribution of different orchestra conductors to the development of the Latvian symphony orchestra conducting school in the period from the beginning of the $20^{\text {th }}$ century and until the end of the World War II. This period is of importance for the author of the study, as it is exactly this period when serious preconditions for the establishment and development of the Latvian symphony orchestra conducting school were created.

Also socially determined processes such as the formation of a conducting school are shaped by the principle of the development of a balanced individual. A conductor who really wants to reach (or already has reached) the top level of art must be a human being, a personality with vast and deep knowledge not only in his professional field, but one must also be a person of generally developed mind, extensive knowledge of culture in general and philosophy in particular. A unique personality is a substantial pre-requisite for the existence and development of a national conducting school.

${ }^{9}$ Latvijas Konservatorija // Ādolfs Ābele. LVA, 1655. f., 1. apr., 16. l., p. 16. 
In the present study the conductors' contribution was analysed evaluating their activities in promotion of the national composers' school, their participation in establishing the conservatory or in its further work, thus enabling the education of the new generation of professional symphony orchestra conductors. Analysis of the experience in leading ensembles, orchestras, musical theatres and choirs acquired by the selected personalities was of special importance, along with their openness towards other music cultures and general contribution to the world music culture. In the course of the research a problem was identified: the methodology principles of symphony orchestra conducting and other theoretical problems have been little studied, also the research dealing with personalities of outstanding conductors is scarce.

\section{References}

\section{Archive sources}

Artūrs Bobkovics. Skolotāja lieta (Artūrs Bobkovics. Teacher's file). LNA LVVA, 1632. f., 1. apr., 2606. 1., 7., 11. lp.

Latvijas Konservatorija. Ādolfs Ābele (Latvian Conservatory. Ādolfs Ābele.) LNA LVA, 1655. f., 1. apr., 16. 1., 2.-22. lp.

Latvijas Konservatorija. Emils Kupers (Latvian Conservatory. Emil Kuper). LNA LVA, 1655 f., 1. apr., 66. 1., 1. lp.

Latvijas Konservatorija. Klases žurnāls. Diriǵentu klase. E. Kupera klase (Latvian Conservatory. Special course, class of the conductor Mr. E. Kuper) 1928./29. m. g. LNA LVA, 1655. f., 1. apr., 722. 1., 1.-5. 1p.

Latvijas Konservatorija. Šnēfogts Georgs (Latvian Conservatory. Schneevoigt Georg) LNA LVA, 1655. f., 1. apr., 116. 1., 1 lp.

Latvijas Konservatorija. Spec. pr. Diriǵgenta E. Kupera k-ga klase (Latvian Conservatory. Special course, class of the conductor Mr. E. Kuper) 1926./27. m. g. LNA LVA, 1655. f., 1. apr., 720. 1., 1. lp.

Latvijas Konservatorija. Spec. pr. Dirigenta E. Kupera k-ga klase (Latvian Conservatory. Special course, class of the conductor Mr. E. Kuper) 1927./28. m. g. LNA LVA, 1655. f., 1. apr., 721. 1., 1.-5. lp.

Latvijas Konservatorija. Spec. pr. Diriǵenta Šnēfogta klase (Latvian Conservatory. Special course, class of the conductor Schneevoigt) 1929./30. m. g. LNA LVA, 1655. f., 1. apr., 724. 1., 1.-5. lp.

Latvijas Konservatorija. Spec. pr. Diriǵenta Šnēfogta klase (Latvian Conservatory. Special course, class of the conductor Schneevoigt) 1930./31. m. g. LNA LVA, 1655. f., 1. apr., 725. 1., 1.-5. lp.

\section{Literature}

Anspaks, J. (2006a). Mākslas pedagogiija 1. daḷa. Mākslas pedagoǵijas teorijas un prakses veidotäji (Art pedagogy, Part 1. The formers of the art pedagogy theory and practice). Rìga: Raka. 
Anspaks, J. (2006b). Mākslas pedagogiija 2. dalı. Metodologiija. Teorija. Prakse (Art pedagogy, Part 2. Metodology. Theory. Practice). Rīga: Raka.

Dārziņš, E. (1975). Raksti. Atminas par Emïlu Dārziṇu (Articles. Recollections of Emīls Dārziņš). Rīga: Liesma.

Grāvītis, O. (2009). Ādolfs Ābele un Dziesmuvara (Power of Song; the choir of the University of Latvia). Rīga: Dziesmuvaras latviešu mūzikas fonds.

Jauǵiets, V. (1970). Artūrs Bobkovics - simfoniskā orḳestra diriǵents. In: Latviešu mūzika (Artūrs Bobkovics - a conductor of symphony orchestra). A. Darkevics un L. Kārkliņš (sak.). Rīga: Liesma.

Kalns, A. (2004). Janka 100. Komponists un diriǵents Jānis Kalniņš mūzikā un dzīvēe (Janka 100. Composer and conductor Jānis Kalniņš in music and life). Rīga: Valters un Rapa.

Kārkliņ̧̌̌, L. (1990). Simfoniskā mūzika Latvijā (The symphonic music in Latvia). Rīga: Liesma.

Karpova, Ā. (1994). Personība un individuālais stils (Personality and an individual style). Rīga: Latvijas Universitāte.

Karpova, Ā. (1998). Personiba. Teorijas un to raditāji (Personality. Theories and their indicators). Rìga: Zvaigzne ABC.

Karpova, Ā. (2005). Personības psihologiskie modeḷi izcilo pedagogiiskās domas kopēju dzivesdarbības atspogul,ojumos (Psychological models of personality in descriptions of the life activities of the outstanding developers of the pedagogical thought.). In: Laikmets un personiba. Krūze, A. (Ed.) (pp. 9-39). Rīga: RaKa.

Krūze, A. (2008). Priekšvārds (A foreword). In: Laikmets un personïba. Rakstu krājums 9 (pp. 4-9). Rīga: RaKa.

Kuper, E. (1988). Stat'i. Vospominanija. Materialy (Articles. Recollections. Materials). Moskva: Sov. Kompozitor.

Maslow, A. (1987). Motivation and Personality. Revised by R. Frager, J. Fadiman, C. McReynolds and R. Cox. [n. d.]: Longman.

Mediņš, J. (1992). Toṇi un pustoṇi (Tones and halftones). Rīga: Liesma.

Sudrabkalns, J. (1926). Atkalredzēšanās ar Šnēfogtu (A reunion with Schneevoigt). Sociāldemokrāts, 28. oktobris, Nr. 243, 4. lpp. 
https://doi.org/10.22364/htqe.2018.16

Ilvis Ābeḷkalns

University of Latvia, Latvia

\title{
SPECIFIC FEATURES OF FOOTBALL CLASS IN GENERAL EDUCATION SCHOOLS
}

\begin{abstract}
The aim of the present study "Specific Features of Football Class in General Education Schools" is to study and analyse specific features of football class in general education schools as well as give recommendations to football club "Metta" and school administration. The author of the study performed qualitative and a quantitative research, the obtained data were analysed using such programs as AQUAD Seven, EXCEL data statistical analysis methods - descriptive statistics, inferential statistics, factor analysis, content analysis.

To obtain data there was semi-structured interview with predetermined set of open questions used in the present work. As a result, the factors prompting dual career in football players, as well as benefits and drawbacks of creating "football class" and working with students on daily basis were found out.

The author has arrived at the conclusion that such "football classes" have positive impact on the team microclimate, and they also save time. Using special programme in secondary school helps to balance study plan, and interorganizational communication should be improved to successfully deal with various questions.
\end{abstract}

Keywords: dual career, football, football class, students, study programme.

\section{Introduction}

Sport is an important part of social and cultural life of $21^{\text {st }}$ century. It is not considered only a hobby or free time activities, but it also plays crucial educational, social, economic and health improvement role in European community. Sport is a compulsory part of the curriculum in general education schools, but this is not enough for students who wish to improve their physical condition and master one of the various kinds of sport. They need to attend additional classes which are not included in 
the school curriculum, participate in study groups, visit sport schools, sport clubs, thus, students' activity schedule becomes too intensive which in turn has negative impact on studying and training process in general.

To pursue dual career, learners-athletes spend much time on their training routine. Each year both curriculum tasks and training activities become more advanced, with higher intensity of training load and growing frequency of sport competitions. This undoubtfully leads to the point when one needs to choose whether to pay more attention to his/her academic studies or training routine to build sport career in future. Football popularity in Latvia has declined dramatically reaching its lowest point $-131^{\text {st }}$ place in FIFA ranking (Latvijas Futbola federācija, 2017). Nevertheless, children and young people are interested in football. The author of the present work searches for the factors determined by the age group. With the maturation of young footballers and increasing of training load studying process has not been paid enough attention to. The research focuses on how the creation of a football class in general educational schools promotes students-athletes' dual career development.

In accordance with Stambulova's (2010) interpretation, "dual career" is a harmonized activity process when an athlete has been developing his physical and academic competence as well as stimulating his psycho-social and psychologic progress (Stambulova, 2010).

The goal of a football class is to ensure growth and development of young athletes without lowering requirements of the National educational standard or reducing training load.

It should be noted that general secondary education helps to acquire skills, attitudes and values which are crucial for higher education studies and the choice of future profession, therefore, this education stage must introduce learners to versatile creative activity experience, thus motivating them to further develop their skills. General secondary education stage should give an opportunity to creatively express oneself in those areas the one is talented in and can continue developing through further education stages. As most of the learners of this age group have not yet decided about their further study direction and are prone to radically change their mind, opportunity of creativity expression must be included in all study programme directions and study subjects (Valsts kanceleja, 2012).

Fernate (2008) in sport theory points out that in the age group of 16 years the main emphasis is put on specific performance and physical condition characteristic of the particular kind of sport. Technical and tactical instruction specific to the particular kind of sport and performance in competition circumstances is accentuated with the integration of cognitive and emotional development. Young football players of this age group are advised to have specific technical, tactical, psychological and 
physical training 9 to 12 times a week (Fernāte, 2008). From the above mentioned it is understood that developing learners' dual career it is significant to organize compact studying and training environment which is related to the social setting of an athlete's daily routine. Family, childhood experience, peers, friends, school environment, mass media have the greatest influence. Sport with its specific activity impact is one of the most important personality development environments both in socialization and enhancing individual competences. This impact is expressed the most in the age of adolescence. Specific environment factors in sport are:

- competition circumstances,

- continuous and monotonous repetitive activity,

- frequent influence of stress situations,

- behaviour of a personality in circumstances of maximum training load,

- expressed influence of achievement motivation on personality performance evaluation (Malina, Clark, 2003).

Education environment, in turn, has been defined as purposefully organized environment (certain set of material, social and mental conditions), where learners form their experience, values, skills, knowledge and attitudes towards themselves and the surrounding world. This is the environment which is created by a person and environment which plays great role in the creation of a person (Šūmane, 2004).

There are similar classes of ice hockey and basketball as well as general education schools with orientation to music and arts created in Latvia.

The aim of the research: to study and analyse specific features of football class in general education schools and give recommendations to football club "Metta" leaders.

Looking at general education law in the Republic of Latvia it is seen that general secondary education curriculum is determined by national general secondary education standard. General secondary education programmes are divided into the following directions:

- General education study direction determined by programme group without specially emphasized study subjects;

- Humanitarian and social study direction determined by programme group with enhanced emphasis on humanitarian and social sciences study subjects;

- Study direction of mathematics, science and technics which is determined by educational programme group putting special emphasis on the related study subjects;

- Professional study direction which is determined by educational program group where professional orientation (e.g. in art, music, commercial sciences, sport) has been accentuated. 
General education programmes are implemented in secondary schools or gymnasiums where full primary education curriculum has been accomplished. A gymnasium basically carries out only general secondary education programmes but there may also be completed a part of primary education curriculum starting from Form 7. At least 2 or 3 educational programme directions is a must in gymnasium. Learners of the same class belong to one educational programme direction (Saeima, 1999).

General secondary direction-oriented programme (code: 31014011) beginning with Form 10 has been implemented in the target school of the present research. The programme focuses on commercial sciences or is sport-oriented (football).

\section{Research Methodology}

Research was performed, interview questionnaire as measuring instrument was created taking into consideration similar published studies of high-performance athletes' dual career (Wylleman, Lavallee, 2004; Aquilina, 2009). Eight teachers and trainers of the sport school took part in the present research. Three of them were "football class" teachers with work experience from 4 to 20 years, and five were sport school trainers with work experience from 5 to 12 years.

The obtained data were processed and analysed by qualitative data analysis program AQUAD Seven, EXCEL data statistical analysis methods descriptive statistics, inferential statistics, factor analysis, content analysis.

There was conducted semi-structured interview with predetermined set of open questions applied in the present work. Using this type of the interview allows to ask additional questions in the process of the interview and obtain more detailed information if required. Open questions, in turn, reduce tendency to give fixed answers, and thus unbiased data can be obtained (Geske, Grīnfelds, 2006).

Individual interviews were audiotaped and then transcribed for further analysis.

Before the interviews were performed the author of the research had personally met 8 respondents -5 men and 3 women in order to receive their consent to be interviewed and inform about the purpose of the interview. All the obtained data and opinions only appear aggregated. All the interviews were audiotaped. The length of the performed interviews corresponded to the expected -20 to 30 minutes.

The aim of the interviews was to collect information, views and opinions about specific features of football class in general education schools, about how young football players managed both studies at school and training routine. 
Within the present research document analysis was performed in order to compare learners' average grades in study subjects (mathematics, Latvian, foreign language).

\section{Results}

The present research focuses on young football players' dual career in sport and education. Therefore, to obtain more credible data, all the respondents were divided in two groups. Respondents of the first group (R1-3) work at school, but respondents of the second group (R4-8) work at football school.

At the beginning of the study it was found out why education was important to young football players. The respondents gave long and exhaustive answers putting special emphasis on education as a means of gaining stability and a place in the society. Education gives more comprehensive self-understanding, and knowledge helps to obtain better results in sport. The author of the study performed data analysis using the programme AQUAD 7 and arrived at the conclusion that the respondents stressed the importance of future profession, but school representatives, in turn, emphasized the role of education and knowledge played in selfdevelopment and further self-advancement (descriptive code "advancement" was mentioned 10 times).

Dual career in the contest of the present research consists of two components - sport and education, therefore, it is crucial to learn respondents' opinions about what knowledge and skills young footballers developed outside the mandatory curriculum. R2 states: "My long practice at school shows that young athletes and musicians who participate in different after-school activities usually also study well, they are focused, tend to achieve their aims and are able to manage their time." R5 claims that "students are able to work in a team, learn to listen to each other, respect each other". R8 asserts that "football is a game where one has to make decisions independently and very quickly and take responsibility for his/her decisions. Making decisions and acting on them is crucial. Smart football player is a good player, and our players show high intellect both on the field and elsewhere".

Performing opinion analysis, the author concluded that learners-athletes (football players) learned from each other, gained life experience.

There were factors leading to the creation of "football classes" found out in the process of the research. The respondents R4-8 expressed the same opinion about young football players' age impact on the increase of training load and curriculum advancement - the older the athletes, the more school subjects to study and the higher intensity of training load. This resulted in learners-athletes' difficulty to manage their school studies and 
high-intensity training routine. Athletic achievements can be improved by ensuring proper study and training environment. R1 states that "...it was a new challenge to attract pupils, popularize healthy life style."

The author proceeded with clarifying the criteria of creation of "football classes". Summary of respondents' opinions showed that young football players were invited to voluntarily join a football class but with the preference to select the most talented adolescents according to the age group where there are football players no older than 14 years and age group with the players no older than 15 years (U14, U15, etc.) beginning with Form 7. Presently, on average there are 7 to 10 football players in one class, and they are put in one parallel class so that educational work could be planned more easily. Table 1 reflects the benefits and drawbacks observed working with "football classes" for 4 years. R1: “...on the whole, weighing all pros and cons I can admit that there are more positive things, let's say, 60/40".

Table 1. Benefits and drawbacks of "football classes"

\begin{tabular}{|c|c|}
\hline Benefits of a "football class" & Drawbacks of a "football class" \\
\hline $\begin{array}{l}\text { Training and studies are organized at the } \\
\text { same place; } \\
\text { - Unity of the team; } \\
\text { - Predictable sustainability of the football club; } \\
\text { - Trainers belong to the school system; } \\
\text { - The school is attractive to more pupils; } \\
\text { - The school becomes more prestigious; } \\
\text { - The number of boys in secondary school } \\
\text { grades increases; } \\
\text { - Socialization of class mates; } \\
\text { - More free time obtained due to organization } \\
\text { of training activities and studies at the same } \\
\text { place; } \\
\text { - Close cooperation between trainers and class } \\
\text { teachers; } \\
\text { - Learners improve their time management } \\
\text { skills. }\end{array}$ & $\begin{array}{l}\text { - Pupils need to change } \\
\text { educational institution; } \\
\text { - More complicated lesson } \\
\text { planning; } \\
\text { - Less free time; } \\
\text { - Football school gives higher } \\
\text { evaluation to football priority; } \\
\text { - Some learners must spend more } \\
\text { time on their way to and from } \\
\text { school; } \\
\text { - Planning common school } \\
\text { events. }\end{array}$ \\
\hline
\end{tabular}

In order to improve football players' dual career, it was important to find out what aspects interfered with development in both directions. The main factor mentioned by the respondents was lack of time (descriptive code "lack of time" was mentioned 12 times) followed by "lack of motivation" (8 times) and fatigue (6 times). R3 pointed out: “...sometimes after a morning workout he is sitting at the desk with a dazed look in the eyes struggling with fatigue...". Studying the importance of "football classes" the respondents were asked to tell about football players' scores in study subjects. Analysing learners' average grades in study subjects (mathematics, Latvian, foreign 
language) the author of the present work came to the conclusion that football players' average grade was higher $(7,19)$ than class average. This fact was also mentioned in respondents' answers. R2 claimed:"...generally football players are good learners; comparing scores in all subjects I can say that they show better results in Math than language subjects and literature...". The author assumed that this could be related to football players' thinking speed and logical thinking which was crucial for successful football match. R5 stated: 'in our sports school we are always aware of our athletes' grades as we have good cooperation with the teachers. There have even been cases when a player is not allowed to take part in a football match because of low grades...".

During the interviews the respondents were asked to suggest how studying and training process in "football classes" can be improved in future. Summing up the results there appeared a tendency - R1-3 wished better communication from football school (descriptive code "communication" was mentioned 13 times). R2 pointed out that “...we plan different school events, excursions, and on the day of an event football players are absent because they are in a training camp. As they (football school) do not inform us beforehand we do not know whether football players can attend our planned events". The respondents also suggested organization of educational seminars about training routine, dual career, time management for learners, parents, trainers and teachers.

\section{Discussion}

According to Wylleman, Lavallee (2004) dual career of young athletes begins to develop at the age of 13 to 15 when sports specialization stage starts, and fundamental sports skills are mastered. This stage usually runs parallel to studies at secondary school and higher educational institution. Figure 1 reflects dual career development stage of elite athletes (in the oval) corresponding to the situation in Latvia.

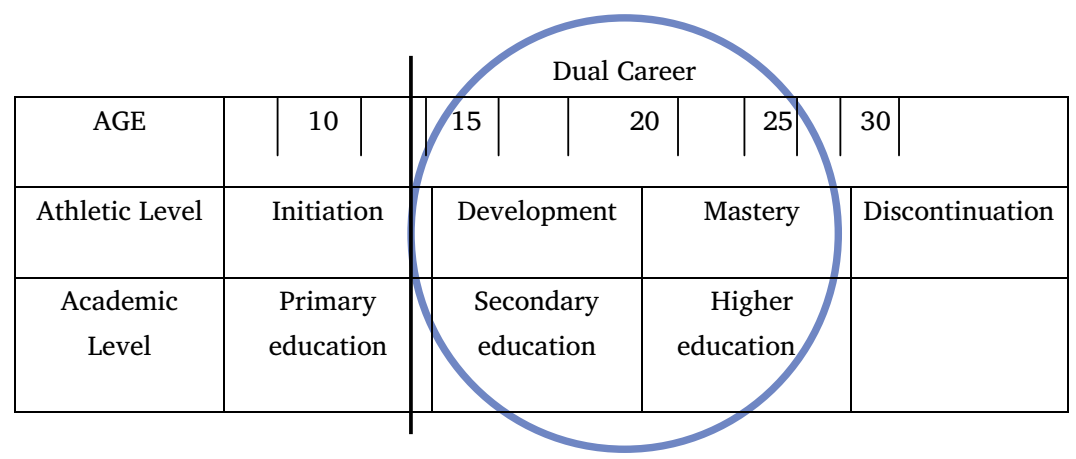

Figure 1. High performance athletes' dual career development stage 
In the figure a straight line marks the period conforming with the age of 13 when secondary schools/gymnasiums carry out a part of primary education programme beginning with Form 7, while, at the age of 15, beginning with Form 10, dual career is being developed expeditiously acquiring general secondary direction-oriented programme (code 31014011) with more profound studies of commercial sciences or sports (football). There is a study plan with the subjects of the programme reflected in the Table 2 .

The respondents R5 and R6 told that secondary school learners studying in "football classes" had 8 lessons and 2 training workouts a day: "some mornings start with a workout, other mornings we have 2 or 3 lessons followed

Table 2. Study subjects and lesson plan of general education secondary school professionally oriented direction (football) programme

\begin{tabular}{|c|c|c|c|c|}
\hline Study subjects & Total & $\begin{array}{l}10^{\text {th }} \\
\text { grade }\end{array}$ & $\begin{array}{l}11^{\text {th }} \\
\text { grade }\end{array}$ & $\begin{array}{l}12^{\text {th }} \\
\text { grade }\end{array}$ \\
\hline Latvian & 210 & 2 & 2 & 2 \\
\hline First foreign language (English) & 315 & 3 & 3 & 3 \\
\hline $\begin{array}{l}\text { Second foreign language (German or } \\
\text { Russian) }\end{array}$ & 315 & 3 & 3 & 3 \\
\hline Mathematics & 525 & 5 & 5 & 5 \\
\hline Informatics & 105 & 2 & 1 & \\
\hline Sports & 420 & 4 & 4 & 4 \\
\hline Biology & 210 & 2 & 2 & 2 \\
\hline Natural sciences & 210 & 2 & 2 & 2 \\
\hline History of Latvia and the world & 210 & 2 & 2 & 2 \\
\hline Literature & 315 & 3 & 3 & 3 \\
\hline Fine arts & 70 & 1 & 1 & \\
\hline Economics & 105 & & 1 & 2 \\
\hline Geography & 105 & 1 & 1 & 1 \\
\hline Culturology & 105 & 1 & 1 & 1 \\
\hline Politics and law & 70 & & & 2 \\
\hline Psychology & 70 & 1 & 1 & \\
\hline Health education & 35 & 1 & & \\
\hline Basics of general pedagogy & 35 & 1 & & \\
\hline Basics of public speech & 70 & & 1 & 1 \\
\hline Football teaching and training methods & 175 & 2 & 2 & 1 \\
\hline Organisation of sports events & 35 & & 1 & \\
\hline LEARNER'S STUDY LOAD & 3710 & 36 & 36 & 34 \\
\hline
\end{tabular}


by training workouts. Then we proceed with school studies until 4 p.m., then the second workout follows. Football players are free every day at around 6 or 6.30 p.m. and can plan their spare time activities".

In regard to lesson planning, R3 admitted: "Lesson planning in secondary school is easier as football players have their special study subjects while other learners have other study subjects related to commercial sciences".

Considering principles of dual career management, not only development tendencies characteristic of modern society (economic, political and social), but also dimensions characteristic of educational management - conceptual, education process management and career education specifics, must be taken into account. It should be noted that both teachers and trainers need to explain to young football players that education is highly important for building their future career.

Figure 2 shows that football players' average grade is 7.19 which is higher than class average, and this leads to a conclusion that sports helps to improve academic achievements. The same can be said about athletes' dual career where studying and training process is a means of selfrealization and personality development. These days, the process of dual career development is accentuated leaving achievements for the future. Dual career incorporates gaining knowledge, developing various skills and effectively managing education and sport career (Ābeḷkalns 2014).

Besides learners' achievements perceptions of their future life and desired social status are being formed. Young people strongly agree that the best way to earn respect of peers is to have pleasant visual appearance

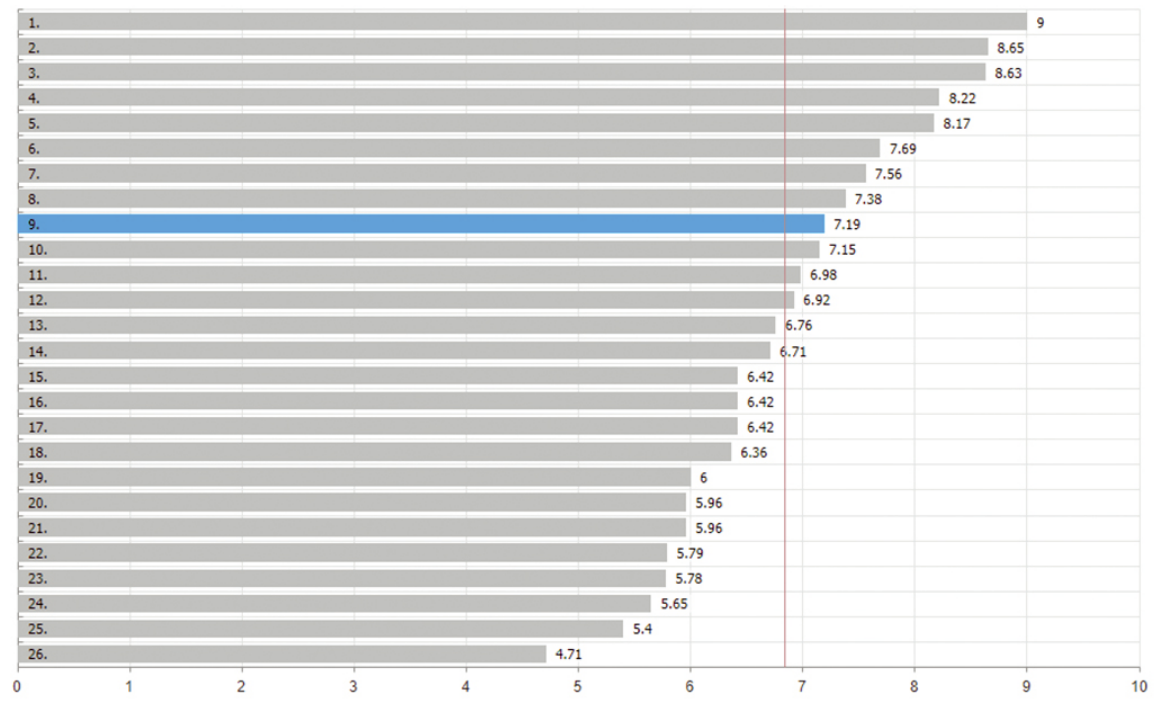

Figure 2. Average grades of a learner-football player 
and athletic achievements, academic achievements are mentioned less. This means that positive motivation among young people prevails over negative, destructive motivation (Koroleva, Rungule, 2009; Акишин, 2013).

Identity formation of young people is highly dependent on the values predominating among them, on friendships they maintain and on the support their friends give. Support from friends can play a significant role in developing sense of belonging to peer group, but lack of supportive friends and attention may lead to negative, destructive leisure activities. Several authors in their research (Koroleva, Rungule, 2009; Ефимова, Будыка, 2003), point out that most of the time teenagers spend talking to each other when they get together. The authors also state that approximately two thirds of young people spend leisure time together with their friends outside their homes going in for sports or doing something else. "Football classes" in this context is a positive factor because football players constantly communicate with other learners during school lessons, thus, obtaining new skills and moving towards their future career.

\section{Conclusions}

On the basis of theoretical and practical analysis of the present research the author concludes that it is educationally, socially, economically important and contributes to health improvement. To pursue dual career, learners-athletes spend much time on their training routine. Each year both curriculum tasks and training activities become more advanced, with higher intensity of training load and growing frequency of sport competitions. This undoubtfully leads to the point when young athletes need to choose whether to pay more attention to their academic studies or devote more time to sport in order to achieve athletic performance mastery in future. The goal of creation of a "football class" is to ensure growth and development of young athletes without lowering requirements of the National educational standard or reducing training load.

Performing the analysis of questionnaire data, the author concludes that in the process of dual career formation young football players consider future profession highly significant, and knowledge obtained at school important to further self-development. Clarifying advantages and disadvantages of a "football class", the respondents admit that there are more advantages, approximately $60 \%$, than disadvantages. A positive aspect is football players' average grade (7.19) which is above class average, and they score better in mathematics than language subjects. Planning of study work both meeting the requirements of training routine and general secondary direction-oriented programme (football) is crucial for successful implementation and continuation of a "football class". 
Recommendations: to improve communication with school working on socialization and taking part into study work planning; to attract more learners of a certain age group to "football classes" so that positive team microclimate is created.

\section{References}

Ābeḷkalns, I. (2014). Augstas klases sportistu duālās karjeras vadība Latvijas augstskolās (High Performance Athletes' Dual Career Management in Higher Educational Establishments of Latvia). Rīga: Latvijas Universitāte. 197 lpp.

Akishin, B. A. (2013). Fizicheskoe vospitanie studentov (Physical Education of Students). Kazan': Izd-vo Kazan. Gos. Tehn. Un-ta.

Aquilina, D. A. (2009). Degrees of Success: Negotiating Dual Career Paths in Elite Sport and University Education in Finland, France and the UK: a Doctoral Thesis. Loughborough (UK): University of Loughborough.

Efimova, I. V., Budyka, E. V., Prohodovskaja, R. F. (2003). Psihologicheskie osnovy zdorov'ja studentov (Psychological Basis of Students' Health). Irkutsk: Irkut. Un-t.

Fernāte, A. (2008). Vispusība - galvenais princips bērnu un jauniešu sportā (Comprehensiveness - the Main Principle in Children's and Youth Sport). No: Bērnu un pusaudžu trenera rokasgrāmata. Rīga: Latvijas Treneru tālākizglītības centrs, 36.-48. lpp.

Geske, A., Grīnfelds, A. (2006). Izglitïbas pētniecỉba (Educational Research). Rīga: LU Akadēmiskais apgāds.

Koroḷeva, I., Rungule, R., Sniķere, S., Aleksandrovs A. (2009). Jauniešu identitāte un līdzdalība (Youth Identity and Participation). No: Latvijas jaunatnes portrets: integrācija sabiedrībā un marginalizācijas riski. Rīga: LU Akadēmiskais apgāds, 145.-188. lpp.

Latvijas Futbola federācija (2017). Latvijas futbola izlase (Latvian Football Team). Retrieved from http://www.lff.lv/lv/latvijas-izlases/viriesu-izlases/nacionala-izlase/) [accessed 10.01.2013].

Malina, R. M., Clark, M. (2003). Youth Sports - Perspectives for a New Century. Monterey: Coaches Choice.

Saeima (1999). Vispārējās izglitïbas likums (Law on General Education). Retrieved from https://likumi.lv/doc.php?id = 20243 [accessed 12.01.2017].

Stambulova, N. (2010). Why a Dual Career? Consideration Based on Career Development Research in Sport Psychology. Paper presented at the Dual Career Conference, Bosön, Sweden.

Šūmane, I. (2004). Mācību vides veidošanās (Formation of the Learning Environment). Izglītības zinātnes un pedagoğija mūsdienu pasaulē. Latvijas Universitātes Raksti, 670. sēj. Rìga: LU, 70.-75. lpp.

Valsts kanceleja (2012). Starpziņojums par Latvijas izglïtibas novērtējumu radošās izglitibas joma (Interim Report on the Evaluation of Latvian Education in the Field of Creative Education). Retrieved from https://www.mk.gov.lv/sites/default/files/ editor/starpzinojums_par_latvijas_izglitibas_sist_novertejumu_radosas_izgl.pdf. [accessed 12.01.2018].

Wylleman, P., Lavallee, D. (2004). A Developmental Perspective on Transitions Faced by Athletes. In: Weiss, M. (ed.) Developmental Sport and Exercise Psychology: A Lifespan Perspective (pp. 507-527). Morgantown, WV: Fitness Information Technology. 


\title{
THE RELATION OF THE ICT USE PATTERNS WITH STUDENTS' READING LITERACY ACHIEVEMENT IN IEA PIRLS AND OECD PISA
}

\begin{abstract}
The article deals with one of the contextual aspects that plays an important role in understanding the factors affecting modern reading literacy - the association of the information and communication technologies (ICT) use patterns with the students' literacy achievement. The relationship between the use of ICT and student achievement in reading literacy and the trends of overall development of achievement in reading literacy have been analyzed by using Latvian data from IEA PIRLS and OECD PISA studies. The research question is: How is the usage of ICT linked to the reading literacy achievement of students? The main results of the study show that there is a negative relationship between student achievement in reading and ICT use at school and at home in Latvia. Therefore it can be concluded that the role of technology in the field of general education might be heavily overrated or its full positive potential might be much harder to be meaningfully implemented in students' everyday learning activities as it seems at the first glance. Equipping a child and/or a teacher with huge amount of different ICT tools and letting them be is not the right approach if an excellence in education is what we are all heading to.
\end{abstract}

Keywords: reading literacy, achievement in reading, ICT, PIRLS, PISA.

\section{Introduction}

In this article the data from the IEA (International Association for the Evaluation of Educational Achievement) PIRLS study (the Progress in International Reading Literacy Study) and the OECD (the Organisation for Economic Co-operation and Development) PISA study (Programme for International Student Assessment) about students' reading achievement in 
correlation with their reported frequency of the usage of ICT at home and at school environments are analyzed and compared.

IEA PIRLS is an international reading literacy study which is composed of a reading comprehension test for $4^{\text {th }}$ grade students followed by a student questionnaire and accompanied with parent, teacher and school questionnaires to help to gather not only the achievement data but also as much context information as possible along with the test results. This approach of large scale studies covers up an enormous field of information to be used in evidence-based educational research and policy. PIRLS is conducted every 5 years since year 2001 and usually the size of a representative sample in each participating country is around 4000 students.

OECD PISA also is worldwide study which measures performance of 15-year-olds in the fields of reading, math and science. OECD PISA study also exploits context questionnaires along with the testing. Since 2000 PISA study is repeated every 3 years.

Since both - the PIRLS and the PISA study deal with students' achievement in reading, definitions of reading literacy used by each of the studies are provided. The definition of reading literacy driving the PIRLS 2016 cycle is as follows:

"Reading literacy is the ability to understand and use those written language forms required by society and/or valued by the individual. Readers can construct meaning from texts in a variety of forms. They read to learn, to participate in communities of readers in school and everyday life, for enjoyment." (Mullis \& Martin, 2015, p. 12).

In PISA 2015 a definition of reading literacy was rather similar:

"Reading literacy is understanding, using, reflecting on and engaging with written texts, in order to achieve one's goals, to develop one's knowledge and potential, and to participate in society." (OECD, n.d.).

Reading literacy is a complex cultural and social phenomenon that has a profound impact on our lives, both at the individual and at the community level.

In general, this skill should be discussed in various dimensions (Knaflič, 2012):

- Linguistic,

- Cognitive,

- Social and cultural,

- Developmental,

- Educational.

Taking into account the place and role of reading in the development, growth and living of each person, the IEA and the OECD research programs (IEA PIRLS, OECD PISA) have been focusing on various aspects of reading literacy for more than 20 years, including context factors that could 
be related to reading literacy achievement among different age students (Leino, 2014; OECD, 2005; OECD, 2015). In this article the authors draw attention to one of today's very topical issues related to reading literacy - the relationship between the use of information and communication technology (ICT) and the reading literacy achievement of students in general education.

The use of computers in the teaching process is based on a variety of grounds, including the need to provide students with the opportunity to become full members of today's digitalized society who have the necessary digital competence to successfully compete in the labor market. For teachers, the extensive use of ICT at school makes it possible to try and implement a new teaching methodology. For these reasons, significant resources are being allocated in many countries of the world for the purchase of computers, the Internet and software for school purposes. However, as illustrated by the results of the IEA PIRLS and OECD PISA studies, schools and education systems as a whole have not been as effective in capturing the potential of ICT as it could have been expected.

The beginning of the 80's of the last century was a time when the world was increasingly focused on the rapid development of modern technology and its growing influence on various areas of society's life, including education. Integrating ICT in education is a complex process that involves both changes in teacher education and the changes in the content and goals of teaching, and the provision of special infrastructure in educational institutions. Given the complexity of the integration process, the uncertainties about the effectiveness of ICT use in learning and the need for research on innovative ICT-related pedagogy, between the years 1990 and 2006, the IEA organized and implemented a number of full-scale, detailed research on the integration of modern technology and its role in general education schools as well as the study of various methodological and didactic aspects related to the use of ICT in training (COMPED (Computers in Education Study), SITES (Second Information Technology in Education Study) and SITES 2006) (Pelgrum, Plomp, 1991; Pelgrum, Anderson, 2000; Pelgrum, Janssen-Reinen, Plomp, 1993; Grinfelds, Kangro, 1996). At least two major studies on ICT education should be noted in the period to 2015: International Report ICILS (Fraillon, et al., 2013) issued by IEA in 2013 and European Commission Survey on ICT in Education, 2013 (European Commission, 2013).

\section{Methods and results}

All data on student achievement in reading literacy used in this section is derived from public databases of the international studies of IEA PIRLS and OECD PISA. Standard error calculations were performed according to an internationally accepted methodology (see for example, Martin, M. O., 
Mullis, I. V. S., \& Hooper, M., 2017). All differences of achievement regarding different groups of students and contextual factors presented in tables were statistically significant. One of the contextual factors of these studies was the use of information and communication technology habits and their possible links with the achievements in reading literacy (Ozola, 2017; Geske, Ozola, 2007; Geske, et al., 2015).

In both studies student surveys included questions about how often computers were used. In the IEA PIRLS 2016 study $4^{\text {th }}$ grade students were asked how often they use computer at home and at school (see Figure 1).

\section{How often do you use a computer or tablet in each of these places for schoolwork (including classroom tasks, homework, or studying outside of class)?}

Fill one circle for each line.

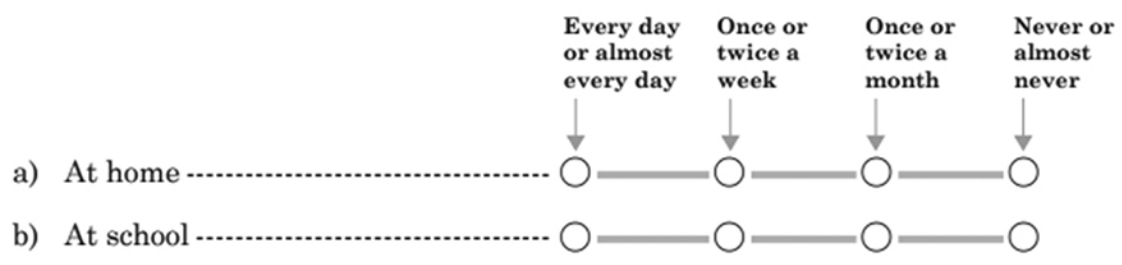

Figure 1. A student questionnaire item about the frequency of computer use from the IEA PIRLS 2016 study

The Latvian students' answers to this question were summarized, linking them with the average reading literacy achievement. The study found that the increased use of computers both at home and at school was associated with lower average achievement in reading literacy (see Table 1).

It should be noted that the negative link was more pronounced in terms of computer use at school: the students who replied that they used computers at school every day, had 32 points lower average reading literacy result than those who said that they did not use computers at school.

The more frequent use of the computer at home was also associated with lower average achievement, but the difference was less pronounced for the students who replied that they use computer at home every day, the average score in the reading literacy test was 15 points lower than for those students who said that they did not use the computer at home at all.

Contrary, when students' access levels of digital devices at home are analyzed in the context of reading literacy achievement, results show that higher access to devices is associated with higher average achievement score in the PIRLS test (Mullis, Martin, Foy, Hooper, 2017). According to (Martin, Mullis, Hooper, 2017), those children whose parents reported having computer/tablet and internet connection along with 7 or more 
Table 1. The average achievement in reading comprehension of Latvian $4^{\text {th }}$ grade students in relation to the frequency of use of computers at home and at school (IEA PIRLS 2016)

\begin{tabular}{|c|c|c|c|c|c|}
\hline \multirow{2}{*}{$\begin{array}{l}\text { Computer } \\
\text { use }\end{array}$} & \multicolumn{4}{|c|}{$\begin{array}{l}\text { Frequency of computer use and average } \\
\text { achievement (Latvia; IEA PIRLS } 2016 \text { reading test) }\end{array}$} & \multirow{2}{*}{$\begin{array}{l}\text { Achievement dif- } \\
\text { ference between } \\
\text { answer categories } \\
\text { "never..." and } \\
\text { "every day..." }\end{array}$} \\
\hline & $\begin{array}{c}\text { Never or } \\
\text { almost } \\
\text { never }\end{array}$ & $\begin{array}{l}\text { Once or } \\
\text { twice a } \\
\text { month }\end{array}$ & $\begin{array}{c}\text { Once or } \\
\text { twice a } \\
\text { week }\end{array}$ & $\begin{array}{c}\text { Every day or } \\
\text { almost every } \\
\text { day }\end{array}$ & \\
\hline At home & 567 & 572 & 563 & 552 & -15 points \\
\hline At school & 567 & 565 & 550 & 535 & -32 points \\
\hline
\end{tabular}

digital devices and a digital device for reading both for parent and a child, were fitted in the high index category. The average reading achievement of Latvian students in this category was 572 score points. The medium access category included children whose parents responded that they have a computer/tablet or an Internet connection, 4-6 digital devices and a digital device for reading either for parents or children. The average reading literacy score of pupils in this index category in Latvia was 556 points which is significantly lower than in the high access index category. And pupils who did not have a digital device for reading, computer/tablet or internet at home and whose family only had up to three digital devices in the household, were assigned to the index category of low access to digital devices at home. In Latvia the average PIRLS score of this index group could not be estimated because there were almost no students who fitted in the low access index category. The same pattern where a higher access to digital devices at home was associated with higher students' reading literacy scores was found in all PIRLS 2016 countries.

In this case the positive relationship between access to digital devices at home and reading literacy results in PIRLS can very well be attributed to the socio-economic status of the family. It has been well proven that the socio-economic situation of the family is the strongest factor influencing student achievement (Papanastasiou, Paparistodemou, 2007; Tinklin, 2003; Johansone, 2009).

Many studies have shown that various proxy measures of social class (usually referred to as socio-economic status, or SES), such as mother's education, parents' education, articles or books in the home, are correlated with students' academic achievement (Carnoy, et al., 2013). Researchers (Papanastasiou, Paparistodemou, 2007) claim that it is a well-known fact that students' SES influences their learning achievement at school. There are proofs of learning performance correlating with social advantages found in econometric research as well (Entorf, Minoiu, 2004). So, the availability of digital devices at home has to be perceived solely as an indicator of 
family SES and the fact of owning a wide range of ICT devices cannot help to predict a purposefulness of its usage and capacity of raising students' reading literacy.

In the OECD PISA study, since the first cycle in the year 2000, survey respondents - fifteen-year-olds in general education also had to respond to a number of questions related to the use of information and communication technology, including the length of time students use computers at school and at home, and the use of different peripherals, Internet etc. In this paper, authors drew attention to just a few of the factors mentioned above and their possible association with student achievement in the reading literacy domain of the OECD PISA test.

The Latvian students' achievements in reading skills in the OECD PISA 2009-2015 cycles were negatively related to the frequency of use of ICT at school (see Table 2). The average reading achievement of 15-year-olds who "rarely or totally not" used computers at school was by 68 points higher than for students who used computer at school "often or every day".

Table 2. The frequency of use of ICT in school and the average achievement of Latvian students in the OECD PISA 2015 test

\begin{tabular}{|c|c|c|c|}
\hline \multirow{2}{*}{$\begin{array}{c}\text { Reading literacy part of } \\
\text { OECD PISA test }\end{array}$} & \multicolumn{3}{|c|}{$\begin{array}{r}\text { The frequency of ICT use in school and the average } \\
\text { achievement of Latvian students } \\
\text { in the OECD PISA 2015 test }\end{array}$} \\
\cline { 2 - 4 } & $\begin{array}{c}\text { Never or hardly } \\
\text { ever }\end{array}$ & Sometimes & $\begin{array}{c}\text { Frequently or } \\
\text { every day }\end{array}$ \\
\hline Reading & 506 & 480 & 438 \\
\hline
\end{tabular}

The OECD PISA 2009 survey found similar results in relation to the average student achievement in reading and computer use at school (see Table 3).

Table 3. Average achievement of Latvian students in reading, mathematics and science depending on the intensity of computer use at school (OECD PISA 2009)

\begin{tabular}{|c|c|c|}
\hline School subject & $\begin{array}{c}\text { Duration of computer use in the } \\
\text { subject within a study week }\end{array}$ & $\begin{array}{c}\text { Average performance in } \\
\text { OECD PISA 2009 }\end{array}$ \\
\hline \multirow{3}{*}{ Latvian language* } & None & 494 \\
\cline { 2 - 3 } & $1-30$ minutes & 477 \\
\cline { 2 - 3 } & 31-60 minutes & 439 \\
\hline More than 60 minutes & 431 \\
\hline
\end{tabular}

* If the student participated in the survey using the Russian language, the wording here was "Russian language". 
The result was similar also in other countries participating in the OECD PISA study, such as Germany, Greece, Japan and Korea. Overall, more intensive use of computer at school in about half of the research countries was associated with lower student achievement not only in reading but also in other areas of the test content (mathematics and science). Why is this happening? An unequivocal answer cannot be given, as the education systems of the countries are different, and the ICT use strategy is different.

\section{Discussion and conclusions}

Neither IEA PIRLS nor the OECD PISA study did a detailed and thorough study of the various uses of ICT in a general education school.

The IEA PIRLS study did not focus in detail on ICT use and reading literacy, as the student questionnaire contained only three questions about computer use at school and at home.

Students' questionnaires of OECD PISA in all cycles, from 2000, included a wider ICT module with 10 to 15 questions on various computer, peripheral, Internet, and software habits at school and at home. Considering that the inclusion of the ICT question module in the survey was not mandatory, a detailed analysis of ICT usage and achievement commitment was not put forward as the main task of the study.

It must be admitted that the IEA PIRLS and OECD PISA research on the use of ICT and the Internet is slightly superficial, but they indicate that there is no positive relationship with the more intensive use of ICT and reading achievement for students from grade 4 to grade 9 .

In general the relationship between the use of ICT and students' reading achievement is not unequivocal. As stated by Tse, Lam, Loh, and Cheung (2017, p. 4-5) "as for the use of computer software or Internet materials in reading lessons, analysis of the evidence gathered in PIRLS 2016 is not sufficiently comprehensive to establish with certainty whether more extensive use of information and communications technology (ICT) in lessons was definitely associated with higher literacy attainment". The researchers from Hong Kong also concluded that teachers seem to need more support in using computer hard and software to facilitate students' high-level reading strategy development (Tse, et al., 2017).

This conclusion is totally in-line with what has been found as the result of the analysis presented in this paper. It is clear that Latvian teachers definitely need well targeted support and methodological advice on how to use computers meaningfully and fruitfully in the process of learning and especially in the process of learning to read during all stages of general education. 
In both the OECD PISA and the IEA PIRLS study, more intensive computer use at school is associated with lower reading performance. It may be explained in one of the following ways, however, without further research, one cannot safely assert which ones are relevant and which are the less important:

- The strategy of the teaching process envisages more intensive work with computers for students whose achievement is lower,

- To students with lower achievement working with computers takes a relatively longer time,

- A longer time at a computer can be a demotivating factor in learning.

Taking into account that similar results were also obtained in the OECD PISA study cycle 2006, it can be argued that the integration of ICT in education and the methodology of computer use in general education schools is not sufficiently substantiated and elaborated. These results require a serious reflection on issues related to the use of ICT in the learning process, as it cannot be considered appropriate to use intensive computer and Internet-based methodology in the school associated with a decline in achievements in such important learning areas as reading.

Therefore, it should generally be acknowledged that the three OECD PISA cycles found that the increase in intensive use of computers at school is not related to student achievement growth in any of the content areas of the study, including reading. This raises the important issue of ICT integration in education: How can computer use improve the learning process by creating the added value of directly using ICT? This is confirmed by OECD Education Director A. Schleiher's saying that "school technology has raised too many false hopes" (Coughlan, 2015).

\section{Summary}

- The OECD PISA research data on ICT infrastructure and usage shows that schools and education systems as a whole have not been as effective in attracting technology potential in the learning process as they could have been expected.

- The significant amount of investment in ICT infrastructure does not meet our expected impact of ICT use in general schools.

- The results of the OECD PISA and IEA PIRLS studies showed negative relationship between student achievement in reading and ICT use at school and at home. Therefore, the added value associated with ICT usage at school is currently not ensured in the learning process. 


\section{References}

Carnoy, M., Khavenson, T., Ivanova, A., Rothstein, R. (2013). Can International Test Score Comparisons Inform Educational Policy? A Closer Look at Student Performance in Russia and its Neighbors. Retrieved from http://papers.ssrn.com/sol3/papers. cfm?abstract_id $=2289188$

Coughlan, S. (2015). Computers 'do not improve' pupil results, says OECD. Retrieved from http://www.bbc.com/news/business-34174796.

Entorf, H., Minoiu, N. (2004). What a Difference Immigration Law Makes: PISA Results, Migration Background and Social Mobility in Europe and Traditional Countries of Immigration. Discussion Paper Series, IZA DP No. 1021. Retrieved from ftp.zew.de/pub/ zew-docs/dp/dp0417.pdf.

European Commision (2013). Survey of Schools: ICT in Education. Benchmarking Access, Use and Attitudes to Technology in Europe's Schools. FINAL REPORT. A study prepared for the European Commission DG Communications Networks, Content \& Technology. Belgium, Brussels. DOI:10.2759/94499.

Eurydice (2011). Lasītprasmes mācišana Eiropā: konteksts, rīcïbpolitika un prakse. Belgium, Brussels, Education, Audiovisual and Culture Executive Agency.

Fraillon, J., Ainley, J., Schulz, W., Friedman, T., Gebhardt, E. (2014). Preparing for Life in a Digital Age. The IEA International Computer and Information Literacy Study International Report. Springer Open.

Geske, A., Grīnfelds, A., Kangro, A. (Ed.), Kisel̦ova, R., Mihno, L. (2015). Quality of Education: International Comparison. Latvia in OECD Programme for International Student Assessment. Educational Research in Latvia, No. 8. Riga: University of Latvia. Retrieved from https://www.ipi.lu.lv/fileadmin/user_upload/lu_portal/projekti/ipi/Publikacijas/ Quality_Of_Education_-_WEB.pdf.

Geske, A., Ozola, A. (2007). Skolēnu sasniegumi lasïtprasmē Latvijā un pasaulē. Izglītības pētniecība latvijā, Nr. 5. Rīga: LU Akadēmiskais apgāds.

Grinfelds, A., Kangro, A. (1996). Policies on Computers in Education in the Republic of Latvia. Technology-Based education Series. Vol. I. Cross National Policies and Practices on Computers in eucation. Tj. Plomp, R. Anderson, G. Kontogiannopoulou-Polidorides (Eds.). The Netherlands: Kluwer Academic Publishers, p. 319-339.

Johansone, I. (2009). Managing primary education in Latvia to assure quality and achievement equity. Promotion Paper. Riga: University of Latvia.

Knaflič, L. (2012). Psychological aspects of literacy. Libellarium, VII, 1, 41-53. UDC: 028.2:159.946.4. Proceedings of the Summer School in User Studies (SSUS). Zadar, Croatia, 11-14 April, 2012.

Leino K. (2014). The relationship between ICT use and reading literacy. Finland: Jyväskylä University Press.

Martin, M. O., Mullis, I. V. S., \& Hooper, M. (Eds.) (2017). Methods and Procedures in PIRLS 2016. Retrieved from https://timssandpirls.bc.edu/publications/pirls/2016methods.html.

Mullis, I. V. S., \& Martin, M. O. (Eds.) (2015). PIRLS 2016 Assessment Framework. $2^{\text {nd }} e d$. Retrieved from http://timssandpirls.bc.edu/pirls2016/framework.html. 
Mullis, I. V. S., Martin, M. O., Foy, P., \& Hooper, M. (2017). PIRLS 2016 International Results in Reading. Retrieved from http://timssandpirls.bc.edu/pirls2016/international-results/; Library of Congress Catalog Card Number: 2017951161, ISBN: 978-1-889938-44-8.

OECD (2005). Are Students Ready for a Technology-Rich World? What PISA Studies Tell Us. Paris, OECD Publications.

OECD (2015). Students, Computers and Learning. Making the Connection. PISA, OECD Publishing.

OECD [n. d.]. PISA 2018 reading literacy framework. Retrieved from http://www.anep. edu.uy/anep/index.php/codicen-publicaciones/category/143-pisa2018?download = 2162:marco-conceptual-lectura-pisa2018.

Ozola A. (2017). Starptautiskā lasītprasmes novērtēěanas pētijuma IEA PIRLS 2016 pirmie rezultāti par 4. klašu skolēnu lasitprasmi Latvijā un pasaulē. Rīga, Latvijas Universitāte.

Papanastasiou, E. C., Paparistodemou, E. (2007). Examining educational technology and achievement through latent variable modeling. In: Loveless, T. (Ed.) Lessons Learned: What International Assessments Tell Us about Math Achievement. Washington, D.C.: Brookings Institution Press. Retrieved from http://www.iea.nl/fileadmin/user_upload/ IRC/IRC_2006/Papers/IRC2006_Papanastasiou_Paparistodemou.pdf.

Pelgrum, W. J., Anderson, R. E. (2000). ICT and the Emerging Paradigm for Life Long Learning: a Worldwide Educational Assesment of Infrastructure, Goals and Practices. The Netherlands, University of Twente.

Pelgrum, W. J., Janssen Reinen, I. A. M. and Plomp, Tj. (Eds.) (1993). Schools, Teachers, Students and Computers: a Cross-National Perspective. IEA-Comped Study Stage 2. The Netherlands, Enschede, IEA.

Pelgrum, W. J., Plomp, Tj. (1991). The Use of Computers in Education Worldwide. Results from the IEA "Computers in Education" Survey in 19 Education Systems. United Kingdom: Pergamon Press.

Tinklin, T. (2003). Gender Differences and High Attainment. British Educational Research Journal, 29(3), 307-325.

Tse, S. K., Lam, W. I., Loh, K. Y., Cheung, W. M. (2017). Progress in International Reading Literacy Study (PIRLS) 2016 International Report (Hong Kong Section). Press Release. Retrieved from https://www.hku.hk/f/upload/17208/PIRLS2016_e.pdf. 
Manuel Joaquín Fernández González, Tamāra Pīgozne, Svetlana Surikova, Lubova Vasečko

University of Latvia, Latvia

\title{
VOCATIONAL EDUCATION INSTITUTION LEADERS' VIRTUES AND EDUCATIONAL LEADERSHIP PROFILE IN LATVIA: A PERSONALITY PERSPECTIVE OF EDUCATION QUALITY
}

\begin{abstract}
Considering the topicality of vocational education and training (VET) in Latvia, and the relevance of school leaders' personality and leadership abilities for education quality, the purpose of this research paper was to explore the associations between VET institution leaders' civic, intellectual, moral and performance virtues, and the different dimensions of their leadership (charismatic, cultural, emotional, formative, participatory, professional, administrative and anticipatory), using mixed methods research for exploring staff's and students' views about it.

Two groups of research questions guided the study: one about the pedagogical leadership dimensions: What are the most salient pedagogical leadership dimensions of three high-level Latvian VET institutions' leaders; what are the differences between students' and staff's opinions about how their institution leaders embody those dimensions?; and the other group of questions about the associations between leaders' virtues and leadership dimensions: Which leadership dimensions and virtues are more often associated in respondents' discourse about their institution leaders; and what are the differences between respondents' groups regarding these associations? Data collected in 3 high-quality VET institutions from different fields (tourism, sports and maritime education) were used for secondary analysis. The quantitative part of the study was based on 83 answers to the standardized questionnaire "Pedagogical Leadership and Quality of Education". The qualitative part of the study was based on seventeen semistructured interviews: 6 with leading staff, 5 with teachers and 6 with students. Latent content regarding leaders' virtues was explored using qualitative data analysis software AQUAD 7.
\end{abstract}


The most salient leadership dimensions were the 'professional', 'charismatic' and 'emotional' ones. School staff rated the 'professional', 'participatory' and 'cultural' dimensions statistically significantly higher than students. Unexpected associations were found between: leaders' civic virtues and 'charismatic' leadership dimension; intellectual virtues and 'emotional' dimension; and performance virtues and 'participatory' dimension and 'cultural' dimension. Differences among group opinions were also found regarding these associations: students praised VET institution leaders' virtues mostly while speaking about the 'charismatic' dimension of leadership, while leading staff and teachers did so while speaking about the 'emotional' dimension. Leading staff associated VET institution leaders' virtues also with the 'formative' dimension, while teachers - with the 'cultural' dimension.

These results offer an original picture of the specific features of character of the institution leaders and how they are associated with their leadership: these leaders were able to combine personal charisma with civic attitudes and neighbourliness, and to create an emotionally rewarding institutional atmosphere, using their personal acumen and good sense for leading the institution successfully. This study represents also an innovative methodological contribution for investigating educational institution leaders' pedagogical leadership from the lens of virtue ethics.

Keywords: education quality, institution leaders, virtue ethics, pedagogical leadership, vocational education and training.

\section{Introduction}

Education policy makers in Europe and around the world are increasingly aware of the global challenges society is facing in the $21^{\text {st }}$ century, such as tackling environmental issues, reducing corruption, terrorism, social inequalities and increasing employment opportunities (Glenn, et al., 2009). The awareness of the importance of moral agency for addressing these issues, and of the insufficiency of a competence-based educational approach without a strong ethical background, is growing (e.g., Attfield, 2015; Shaw \& Barry, 2015; O’Byrne, 2017).

Another topical concern for education policy makers and educators worldwide is the effectiveness and quality of education. Many external and internal factors contribute to the quality of educational institutions. Recent studies (Taipale, 2012; Fernández González \& Seņkāne, 2015; Çoğaltay \& Karadă̆, 2016; Jäppinen \& Ciussi, 2016; Mårtensson \& Roxå, 2016; Smith, et al., 2017) indicate that quality and effectiveness of education can be partially attributed to the educational leadership practices. Therefore, a research on educational leadership as one of the crucial aspects of the educational process provides an important background for improving this process at all levels of education system. However, the role of pedagogical leadership has changed the last few years, shifting its focus from teaching and learning to professional development (Butt, 2017). Integrated leadership, combining instructional and distributed leadership, 
is an important precondition for creating and sustaining professional learning communities (OECD, 2016a). Many scholars had also stressed the importance of educational leaders' personal qualities and character for ensuring quality of education (e.g., Gurr, 2015; The University of Nottingham, 2015; Butt, 2017). As an example, a recent study (Day \& Gurr, 2011), after a world-wide review of successful school leadership, highlighted the central role of institution leaders' personal qualities and dispositions (such as commitment, resilience, motivation over time, giving priority to establishing good relations), working hard (including courage, commitment and energy), and leaders' beliefs and values (including basic human values as well as moral, professional and social and political values) for leading schools successfully.

Empowering all people of working age to participate in economic and social life through accessible and equitable training opportunities is crucial (European Commission, 2010, p. 3). For vocational education and training (VET) providers, institutional leadership, which shows strategic direction and support collaborative environment for all staff, as well as career development opportunities, is a pivotal condition of success (European Commission, 2012, p. 38). VET provider's quality is built on two key factors, namely good leadership and management. Effective leadership creates a positive organizational culture that values trust, where people are motivated to ask questions, debate issues and contribute to each other's ongoing learning and inquiry (EQAVET, n.d., p. 27).

Latvia, according to recent reports elaborated by CEDEFOP (2015) and OECD (2016b), faces the challenge of improving VET quality and relevance, in order to adequately prepare young people for work, developing adult skills and responding to the needs of the labour-market (OECD, 2016b). Many efforts had been done this direction (The Cabinet of Ministers, 2009; Saeima, 2014; CEDEFOP, 2015; Fernández González, 2015; EQAVET, 2016). In April 2015, the Latvian Parliament (Saeima) adopted amendments to the Vocational Education Law, to ensure a better fit between VET and labour market needs at sectoral, institutional and programme levels (EQAVET, 2016). A new work-based learning model has also been recently initiated (The Ministry of Education and Science, 2014; Fernández González, 2015). Latvian government established sectoral expert councils and collegial advisory bodies (convents) at each VET institution, and created competence centres of vocational education for enhancing synergy between innovationoriented enterprises and scientific institutions in certain sectors (EQAVET, 2016; Latvian Investment and Development Agency, n.d.). In January 2017, a national assessment of all educational institutions leaders (including VET institutions) was launched by the Ministry of Education and Science of the Republic of Latvia (The Cabinet of Ministers, 2016), using international 
quality indicators (EQAVET) and including provisions for implementation of OECD recommendations.

Academics all around the world had addressed this important issue of general education school principalship and leadership (Mulford, 2003; Taipale, 2012; The University of Nottingham, 2015; Gurr, 2015; OECD, 2016a; Uljens, et al, 2016; Butt, 2017, etc.). Successful principals have core sets of deeply held values and moral and ethical purposes, and immense amounts of emotional understandings of themselves and others; are deeply respected and trusted by the communities which they serve; display high expectations and hopefulness in themselves and others; are values led; and perform well in areas such as curiosity, creativity, citizenship, and spirituality (The University of Nottingham, 2015; Gurr, 2015). A principal as a pedagogical leader should be a broad-minded communicator, inspirator, facilitator, and risk-taker, showing enthusiasm, integrity, truthfulness, insightfulness and positive thinking (Butt, 2017).

In the academic field, between 2000 and 2015 several $\mathrm{PhD}$ Theses in the field of school leadership and education management had been defended in Latvia, but this research is fragmentary and does not embrace all aspects of the field (Bluma \& Daiktere, 2016). According to Bluma and Daiktere (2016), after the recovering of the independence of Latvia, one of the first dissertations on education management (Ozola, 2002) discussed the theory of the management of a school and the characteristics of the school principal comparing practices in various countries, and stressed that the school principal should be at the same time a pedagogical leader and an organizer of the work of the school. Celma's dissertation (2004) deals with school principal's role during transition from Soviet education system to democratic school. Another dissertation (Upenieks, 2008) focused on criteria of becoming a school principal, which were based on formal and technical abilities rather than on personal competence. Daiktere's PhD thesis (2012) explores school principals' daily work, and how they influence the formation of the school culture, balancing a personal active role with participative leadership. Their supporting role for enhancing teachers' motivation and improving school culture is also addressed. Kalvans (2012), based on OECD PISA 2006 study, demonstrated the importance of principal's ability to facilitate teachers' professional development and motivation for education quality and the improvement of the learning environment and school microclimate, and provided recommendations for the assessment of quality of the principals' work.

However, till now, there are no academic studies addressing with a modern research methodology the pedagogical leadership of VET institutions in the context of Latvia as a democratic country. Considering the topicality of vocational education and training in the Latvian context, 
and the importance of pedagogical leadership dimensions and educational institution leaders' personality for quality education, it was decided to conduct a mixed method study seeking to highlight the associations between leadership dimensions and character features of pedagogical leaders of VET institutions that are recognized as providing high quality education in Latvia.

\section{Theoretical background}

Two different theoretical backgrounds were used for this study, one regarding virtues and another - leadership dimensions. The "Framework for Character Education" of the Jubilee Centre for Character and Virtues (JCCV) of the University of Birmingham (JCCV, 2017) was used as theoretical background for the analysis of leaders' virtues. The JCCV has largely used this framework for research on character strengths of student and experienced professionals in the fields of teaching, law, medicine, nursing, business and army, but there is not still a research focused on VET school principals using this framework.

The framework includes some prototypical moral virtues recognised and embraced by representatives of most cultures and religions around the world, such as courage (acting with bravery in fearful situations), justice (acting with fairness towards others by honouring rights and responsibilities), honesty (being truthful and sincere), compassion (exhibiting care and concern for others) and gratitude (feeling and expressing thanks for benefits). It includes also specific civic virtues, such as civility, service, citizenship, and volunteering, which regard the person's relations and responsibilities in society. Furthermore, the framework includes the intellectual virtues, which guide the quest for knowledge and information (e.g., curiosity, autonomy, critical thinking, judgement, reasoning, reflection, resourcefulness). This framework addresses also the personal traits that enable the person to manage his/her live effectively under the denomination of performance virtues, including resilience, determination, confidence and teamwork ability.

Gento's model of pedagogical leadership (Gento, 2002) was used as theoretical background for addressing leadership dimensions. This model was designed to be applied in educational institutions and tested with professionals of the educational field. It has been improved continuously since its first version appeared in 1996, contrasting theoretical reflection with the work of professionals and practitioners. According to this conception, educational leadership is characterized by the following eight dimensions: charismatic (attractiveness, trust-inspiring and natural authority), emotional (kindness and consideration of others), anticipatory 
(strategic vision and future-oriented thinking), professional (goal-orientation and competence), participatory (distributive leadership and collaborative style), cultural (identification with institutional culture), formative (promotion of professional development), and administrative (proficiency in bureaucratic and organizational work) (Gento \& González, 2012).

In this paper the authors were particularly interested in highlighting the association of leadership dimensions with positive references to leaders' personality. Based on this theoretical background, four research questions guided our research: a descriptive question about the most salient pedagogical leadership dimensions: an associational question, addressing implicit linkages between leadership dimensions and positive references to VET institutions' leaders' virtues; and two difference questions, for gaining a deeper understanding of group differences regarding opinions on leadership dimensions and their association with leaders' virtues. The questions were formulated as follows:

RQ1: What are the most salient pedagogical leadership dimensions of three

Latvian VET institutions' leaders according to the importance given to and the evidence found of them?

RQ2: What are the differences between students' and staff's opinions about the leaders of those institutions regarding the importance given to and the evidence found of the different pedagogical leadership dimensions?

RQ3: Which leadership dimensions and positive virtues of VET institutions' leaders are more often associated in respondents' discourse?

RQ4: What are the differences between respondents' groups regarding associations of positive virtues with leadership dimensions?

\section{Methodology}

The research was conducted applying a mixed-method approach. In the quantitative part of this study, data obtained in a previous study (2013) by the same research team using a face-to-face assisted web-based questionnaire ("Questionnaire on educational leadership in educational institutions" - 176 items) were used. The questionnaire was elaborated under the direction of Samuel Gento in 2002 (Gento, 2002) and updated in the Fall of 2012 by the research group "Pedagogical Leadership and Quality of Education" at Spain's university UNED, which also translated into English and piloted the questionnaire for usage in international studies such as the present one. The questionnaire addresses the eight dimensions of educational leadership and contains 80 indicators (ten features or characteristics for each leadership dimension).

In the qualitative part of the study, for ethical reasons, the authors decided to avoid asking directly VET teachers and students to make a 
personal evaluation of their VET institution leaders' personality. It was decided to use semi-structured interviews from the same previous study as secondary data for obtaining the necessary information about the features of the character of the pedagogical leaders. The interview guidelines, that were provided in the aforementioned reference frame (Gento, 2002), addressed institution leaders' strengths and weaknesses regarding the leadership dimensions ('charismatic', 'emotional', 'anticipatory' etc.). This approach was less intrusive: respondents spoke freely about their educational leader and, while speaking about how their leaders embodied the different dimensions of leadership, they revealed indirectly the personality characteristics they perceive behind the observed leaders' behaviours. Secondary analysis of these interviews through the lens of virtues provided a rich picture of leaders' personality characteristics.

\section{Participant institutions and data selection}

Two criteria were retained for the choice of the institutions whose primary data were used in this study: recognized excellence in their field, and a profile as different as possible for enriching the perspective of the study. The retained data were collected in three high-quality VET institutions located in Riga. The institution A focussed on tourism and food production, the institution $\mathrm{B}$ worked in the field of maritime education, and the institution $\mathrm{C}$ in the field of sport pedagogy. The time span between primary data collection and its secondary analysis in this study was relatively short (4 years).

In this research, the following primary data (questionnaires and interviews) were used for secondary analysis with a new research focus:

- 83 face-to-face assisted web-based questionnaires: 45 questionnaires from the institution A, 10 from the institution $\mathrm{B}$, and 28 from the institution C. $16 \%$ of the respondents were members of staff $(N=13)$, the rest were students $(N=70 ; 84 \%) .75 \%$ of the respondents were females $(N=62)$.

- 17 interviews: 6 with leading staff, 5 with teachers and 6 with students. 6 interviews were conducted at the institution A (2 students, 2 teachers and 2 members of the leading staff), 4 at the institution B ( 2 teachers and 2 members of the leading staff), and 7 at the institution C (4 students, 1 teacher, 2 members of the leading staff). The average duration was 12 minutes per interview.

All participants in the initial study were informed about anonymization, confidentiality and data protection policy, and they gave informed consent for audio or video recording and data usage for the research. 


\section{Data processing and analysis}

Quantitative data were processed and analysed by two researchers using software SPSS 22. A statistical analysis of quantitative data including both descriptive statistics and inferential statistics (Ho, 2006) was conducted. The descriptive statistics aimed primarily at describing the selected primary data and its major concern was to present information in a convenient, usable, and understandable form. The descriptive statistics were used to describe the data set in terms of frequency of occurrence, central tendency (mean, median, and mode), and dispersion (variances and standard deviations). The reliability and validity of the selected quantitative data set was checked conducting a reliability analysis. The value of Cronbach's Alpha was higher than 0.90 . Therefore, the data set was highly reliable. The Kolmogorov-Smirnov test was used for determining the type of distribution of the statistical data, which were not normally distributed. The non-parametrical Mann-Whitney Test was used for determining the differences between the two respondents' groups (staff and students).

According to Robson and McCartan (2016), in qualitative studies the research question should determine if manifest or latent content analysis should be used. For the reasons explained before, latent content analysis (Neuendorff, 2016) was used in this research for analysing the interviews. A code system based on the JCCV framework (four main codes referring to the four kinds of virtue of the framework, and child-codes corresponding to specific virtues) was adapted for this research and uploaded in a shared Google document for allowing real-time updates of the code list during the coding process. Three coding modes were used for each virtue: positive mode (the virtue is praised), negative mode (respondents complain that the opposite vice is shown in leaders' behaviour) or desirable mode (the respondents stated that it would be desirable that the leader shows a concrete virtue).

Three researchers coded the interviews using AQUAD 7 software (Huber \& Gürtler, 2013), either directly on the audio file or transcribing the interviews. In order to ensure a shared understanding of code content and intercoder reliability, at the beginning of the coding process, researchers coded in pairs two different files. The leading researcher participated in both pairs for unifying the understandings of codes. This step was important because latent content analysis demands a relative high level of inference or interpretation on the part of the coder (Robson \& McCartan, 2016). After that, each researcher worked individually on the interviews of the institution allocated to him or her, coding them and analysing the data with software AQUAD 7 according to a common procedure: if, when answering a question about one of the eight leadership dimensions, 
a respondent mentioned a virtue of the leader, an implicit association between this virtue and this dimension was recorded. Once all files were coded and analysed, the obtained data were assembled in a single Excel file for joint frequency and linkage analysis.

\section{Results}

The presentation of the results was structured according to the research questions. The results regarding the first research question - RQ1 [What are the most salient pedagogical leadership dimensions of three Latvian VET institutions' leaders according to the importance given to and the evidence found of them?] are presented in Table 1 (commented figures highlighted in bold).

Table 1. Importance and evidence of leadership dimensions (Means in a 9-point scale)

\begin{tabular}{|c|c|c|}
\hline Dimension & $\begin{array}{c}\text { Importance } \\
\text { (Mean) }\end{array}$ & $\begin{array}{c}\text { Evidence } \\
\text { (Mean) }\end{array}$ \\
\hline Charismatic & 7.73 & 7.10 \\
\hline Emotional & 7.55 & 7.14 \\
\hline Anticipatory & 7.45 & 7.04 \\
\hline Professional & 7.77 & 7.33 \\
\hline Participatory & 7.37 & 7.00 \\
\hline Cultural & 7.12 & 6.38 \\
\hline Formative & 7.20 & 6.87 \\
\hline Administrative & 7.46 & 7.12 \\
\hline General Mean & 7.46 & 7.00 \\
\hline
\end{tabular}

According to the results of descriptive statistics, the most important dimensions were 'professional' (Mean = 7.77), 'charismatic' (Mean = 7.73), and 'emotional' (Mean $=7.55$ ), and the most evident dimensions were 'professional' (Mean $=7.33$ ), 'emotional' (Mean $=7.14$ ), and 'administrative' (Mean = 7.12). 'Professional' and 'emotional' dimensions were the most salient both in important and evidence. The 'charismatic' dimension was salient in importance and also was rated over the average in evidence.

The results regarding the second research question - RQ2 [What are the differences between students' and staff's opinions about the leaders of those institutions regarding the importance given to and the evidence found of the different pedagogical leadership dimensions?] are presented in Table 2. 
Table 2. Importance and evidence of dimensions (mean rank by the Mann-Whitney test)

\begin{tabular}{l|c|c|r|r|r|r|r}
\hline \multirow{2}{*}{ Dimension } & \multicolumn{3}{|c|}{$\begin{array}{c}\text { Importance by } \\
\text { mean rank }\end{array}$} & \multicolumn{3}{c|}{$\begin{array}{c}\text { Evidence by } \\
\text { mean rank }\end{array}$} & $\begin{array}{c}\text { Sum- } \\
\text { mated } \\
\text { differ- } \\
\text { ence }\end{array}$ \\
\cline { 2 - 8 } & $\begin{array}{c}\text { stu- } \\
\text { dents }\end{array}$ & staff & $\begin{array}{r}\text { differ- } \\
\text { ence }\end{array}$ & $\begin{array}{c}\text { stu- } \\
\text { dents }\end{array}$ & staff & $\begin{array}{r}\text { differ- } \\
\text { ence }\end{array}$ \\
\hline Charismatic & $\mathbf{4 2 . 7 0}$ & 38.23 & 4.47 & $\mathbf{4 2 . 6 6}$ & 38.42 & 4.24 & 8.71 \\
\hline Emotional & $\mathbf{4 2 . 7 2}$ & 38.12 & 4.60 & $\mathbf{4 2 . 5 8}$ & 38.88 & 3.70 & 8.30 \\
\hline Anticipatory & 41.18 & $\mathbf{4 6 . 4 2}$ & -5.24 & 41.39 & $\mathbf{4 5 . 2 7}$ & -3.88 & -9.12 \\
\hline Professional & 39.72 & $\mathbf{5 4 . 2 7}$ & -14.55 & 41.05 & $\mathbf{4 7 . 1 2}$ & -6.07 & -20.62 \\
\hline Participatory & 39.56 & $\mathbf{5 5 . 1 2}$ & -15.56 & 40.98 & $\mathbf{4 7 . 5 0}$ & -6.52 & $\mathbf{- 2 2 . 0 8}$ \\
\hline Cultural & 38.84 & $\mathbf{5 5 . 6 2}$ & -16.78 & 39.88 & $\mathbf{5 0 . 0 8}$ & -10.20 & $\mathbf{- 2 6 . 9 8}$ \\
\hline Formative & 40.02 & $\mathbf{5 2 . 6 5}$ & -12.63 & 40.30 & $\mathbf{4 1 . 5 4}$ & -1.24 & -13.87 \\
\hline Administrative & 41.04 & $\mathbf{4 7 . 1 5}$ & -6.11 & 39.96 & $\mathbf{5 3 . 0 0}$ & -13.04 & -19.15 \\
\hline
\end{tabular}

In general, the students rated higher on importance and evidence of 'charismatic' and 'emotional' dimensions, but the staff (the institution leaders and teachers) rated higher on importance and evidence of all other dimensions. Using the Mann-Whitney Test, statistically significant differences were found between both groups regarding the importance given the 'professional' $(p=.036)$, 'participatory' $(p=.026)$ and 'cultural' dimensions $(p=.015)$. These differences will be addressed in the discussion.

The results regarding the third research question - RQ3 [Which leadership dimensions and positive virtues of VET institutions' leaders are more often associated in respondents' discourse?] are presented in Table 3.

107 associations were found between leadership dimensions and virtues mentioned in a positive mode. Overall, respondents mentioned most often leaders' positive virtues when speaking about the following leadership dimensions: 'emotional' (20 linkages), 'formative' (18), 'anticipatory' (17), and 'charismatic' (15). Although the most salient leadership dimension was the 'professional' one (see Table 1), the number of references to leaders' virtues associated to it is relatively low $(N=11)$. Almost half of the positive virtues mentioned by respondents referred to performance virtues $(N=46$, $45 \%)$, which was particularly associated with the 'participatory' dimension (67\% of the associations within 'participatory' dimension) and the 'cultural' dimension ( $56 \%$ of the association within 'cultural' dimension). A quart of the virtues mentioned were intellectual virtues $(N=28,24 \%)$, and moral and civic virtues account for $15-16 \%$. 
Table 3. Association between leadership dimensions and praised virtues (by type of virtue)

\begin{tabular}{|c|c|c|c|c|c|c|c|c|c|c|c|}
\hline \multirow[b]{2}{*}{$\begin{array}{l}\text { Type of } \\
\text { virtues }\end{array}$} & & \multicolumn{10}{|c|}{ Leadership dimensions } \\
\hline & & 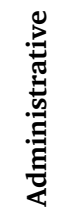 & 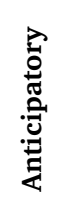 & 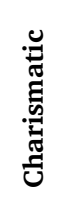 & 丞 & 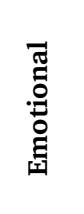 & 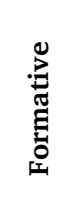 & 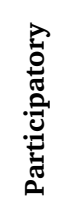 & 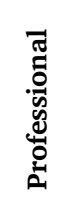 & 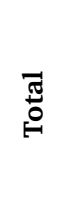 & \\
\hline \multirow{3}{*}{$\begin{array}{l}\text { Civic } \\
\text { virtues }\end{array}$} & count & 1 & 5 & 7 & 1 & 3 & 1 & 0 & 1 & 19 & \\
\hline & $\begin{array}{l}\text { \%within } \\
\text { virtues }\end{array}$ & $5 \%$ & $26 \%$ & $37 \%$ & $5 \%$ & $16 \%$ & $5 \%$ & $0 \%$ & $5 \%$ & $\begin{array}{c}100 \\
\%\end{array}$ & $\begin{array}{c}\text { total } \\
\%\end{array}$ \\
\hline & $\begin{array}{l}\text { \%within } \\
\text { dimensions }\end{array}$ & $13 \%$ & $29 \%$ & $47 \%$ & $11 \%$ & $15 \%$ & $6 \%$ & $0 \%$ & $9 \%$ & $16 \%$ & $\begin{array}{c}\text { mean } \\
\%\end{array}$ \\
\hline \multirow{3}{*}{$\begin{array}{l}\text { Intellectu- } \\
\text { al virtues }\end{array}$} & count & 1 & 2 & 2 & 2 & 8 & 8 & 1 & 4 & 28 & \\
\hline & $\begin{array}{l}\text { \%within } \\
\text { virtues }\end{array}$ & $4 \%$ & $7 \%$ & $7 \%$ & $7 \%$ & $29 \%$ & $29 \%$ & $4 \%$ & $14 \%$ & $\begin{array}{c}100 \\
\%\end{array}$ & $\begin{array}{c}\text { total } \\
\%\end{array}$ \\
\hline & $\begin{array}{l}\text { \%within } \\
\text { dimensions }\end{array}$ & $13 \%$ & $12 \%$ & $13 \%$ & $22 \%$ & $40 \%$ & $44 \%$ & $11 \%$ & $36 \%$ & $24 \%$ & $\begin{array}{c}\text { mean } \\
\%\end{array}$ \\
\hline \multirow{3}{*}{$\begin{array}{l}\text { Moral } \\
\text { virtues }\end{array}$} & count & 2 & 3 & 0 & 1 & 2 & 1 & 2 & 3 & 14 & \\
\hline & $\begin{array}{l}\text { \%within } \\
\text { virtues }\end{array}$ & $14 \%$ & $21 \%$ & $0 \%$ & $7 \%$ & $14 \%$ & $7 \%$ & $14 \%$ & $21 \%$ & $\begin{array}{c}100 \\
\%\end{array}$ & $\begin{array}{c}\text { total } \\
\%\end{array}$ \\
\hline & $\begin{array}{l}\text { \%within } \\
\text { dimensions }\end{array}$ & $25 \%$ & $18 \%$ & $0 \%$ & $11 \%$ & $10 \%$ & $6 \%$ & $22 \%$ & $27 \%$ & $15 \%$ & $\begin{array}{c}\text { mean } \\
\%\end{array}$ \\
\hline \multirow{3}{*}{$\begin{array}{l}\text { Perfor- } \\
\text { mance } \\
\text { virtues }\end{array}$} & count & 4 & 7 & 6 & 5 & 7 & 8 & 6 & 3 & 46 & \\
\hline & $\begin{array}{l}\text { \%within } \\
\text { virtues }\end{array}$ & $9 \%$ & $15 \%$ & $13 \%$ & $11 \%$ & $15 \%$ & $17 \%$ & $13 \%$ & $7 \%$ & $\begin{array}{c}100 \\
\%\end{array}$ & $\begin{array}{c}\text { total } \\
\%\end{array}$ \\
\hline & $\begin{array}{l}\text { \%within } \\
\text { dimensions }\end{array}$ & $50 \%$ & $41 \%$ & $40 \%$ & $56 \%$ & $35 \%$ & $44 \%$ & $67 \%$ & $27 \%$ & $45 \%$ & $\begin{array}{c}\text { mean } \\
\%\end{array}$ \\
\hline \multirow[t]{3}{*}{ Total } & count & 8 & 17 & 15 & 9 & 20 & 18 & 9 & 11 & 107 & \\
\hline & $\begin{array}{l}\text { \%within } \\
\text { virtues }\end{array}$ & $8 \%$ & $18 \%$ & $14 \%$ & $8 \%$ & $18 \%$ & $15 \%$ & $8 \%$ & $12 \%$ & $\begin{array}{c}100 \\
\%\end{array}$ & $\begin{array}{c}\text { total } \\
\%\end{array}$ \\
\hline & $\begin{array}{l}\text { \%within } \\
\text { dimensions }\end{array}$ & $\begin{array}{c}100 \\
\%\end{array}$ & $\begin{array}{c}100 \\
\%\end{array}$ & $\begin{array}{c}100 \\
\%\end{array}$ & $\begin{array}{c}100 \\
\%\end{array}$ & $\begin{array}{c}100 \\
\%\end{array}$ & $\begin{array}{c}100 \\
\%\end{array}$ & $\begin{array}{c}100 \\
\%\end{array}$ & $\begin{array}{c}100 \\
\%\end{array}$ & $\begin{array}{c}100 \\
\%\end{array}$ & $\begin{array}{c}\text { mean } \\
\%\end{array}$ \\
\hline
\end{tabular}

The strongest association was found between civic virtues and the 'charismatic' dimension of leadership: $47 \%$ of the virtues recorded within this 'charismatic' dimension are civic virtues, and more than $1 / 3$ of all civic virtues (37\%) were associated with 'charismatic' dimension. Slightly 
lower bet still high associations were found between intellectual virtues and two leadership dimensions: the 'formative' and 'emotional' ones: $58 \%$ of all intellectual virtues were associated with the 'emotional' or 'formative' dimension in equal proportion ( $29 \%$ each); and $44 \%$ of the virtues associated with the 'formative' dimension were intellectual virtues (the figure for the 'emotional' dimension is $40 \%$ ).

Summarizing the findings about the RQ3 strong associations were found between leaders' civic virtues and 'charismatic' dimension, and between intellectual virtues and the 'formative' and 'emotional' dimensions. These associations will be discussed latter.

The results regarding the fourth research question - RQ4 [What are the differences between respondents' groups regarding associations of positive virtues with leadership dimensions?] are presented in Table 4.

Out of the 107 associations of positive virtues with leadership dimensions, the highest rate of linkages was found within leading staff $(N=44,41 \%)$, and the lowest - within students $(N=26,24 \%)$. Across leadership dimensions, the highest number of association was found within 'emotional' dimension $(N=20,19 \%)$.

Leading staff most often praised leaders' virtues when speaking about 'emotional' and 'formative' dimensions (11 linkages each) and 'anticipatory' dimension (9 linkages). Students praised leaders' virtues when reflecting on the 'charismatic' dimension (8 linkages) and 'professional' dimension (5 linkages). Teachers reported most of leaders' virtues when reflecting on the 'emotional' dimension (8 linkages). They are the group that praised leaders' virtues most often in relation with the 'cultural' dimension of the institution (5 linkages).

Table 4. Frequency of linkages of virtues (positive mode) with leadership dimensions by respondents' group

\begin{tabular}{lccccc}
\hline \multirow{2}{*}{ Leadership dimension } & \multicolumn{3}{c}{ Respondents' group } & \multirow{2}{*}{ Total } & \multirow{2}{*}{$\%$} \\
\cline { 2 - 5 } & Leading staff & Student & Teacher & & \\
\hline Administrative & 3 & 1 & 4 & 8 & $7 \%$ \\
Anticipatory & $\mathbf{9}$ & 4 & 4 & 17 & $16 \%$ \\
Charismatic & 2 & $\mathbf{8}$ & 5 & 15 & $14 \%$ \\
Cultural & 3 & 1 & $\mathbf{5}$ & 9 & $8 \%$ \\
Emotional & $\mathbf{1 1}$ & 1 & $\mathbf{8}$ & 20 & $19 \%$ \\
Formative & $\mathbf{1 1}$ & 2 & 5 & 18 & $17 \%$ \\
Participatory & 3 & 4 & 2 & 9 & $8 \%$ \\
Professional & 2 & $\mathbf{5}$ & 4 & 11 & $10 \%$ \\
Total (\%) & $44(41 \%)$ & $26(24 \%)$ & $37(35 \%)$ & 107 & $100 \%$ \\
\hline
\end{tabular}


Summarizing the findings about the RQ4, leading staff has the highest number of positive virtues linked to leadership dimensions, and respondents most often praised leaders' virtues when speaking about 'emotional' and 'formative' dimension. Students have the lowest number of associations, which appeared mostly around the 'charismatic' dimension; most of the teachers' mentioned virtues were associated with the 'emotional' dimension.

\section{Discussion}

The focus of this discussion is the associations between leadership dimensions and virtues (RQ3), and the differences among groups (RQ4). The quantitative results of the study were used in the discussion when it was necessary for gaining deeper understanding about a concrete leadership dimension (RQ1) or about group specificities (RQ2). In the Figure 1, the main associations of leadership dimensions with the different kind of virtues and with respondent groups' activity mentioning virtues are visualized.

As it can be seen (see Figure 1), students seemed to adopt a position different from leading staff and teachers. They praised most of VET institution leaders' virtues when speaking about the 'charismatic' dimension of leadership, which is strongly associated with civic virtues. On the other hand, both leading staff and teachers were very active recalling leaders' virtues when speaking about the 'emotional' dimension of leadership and, for the leading staff, when speaking about the 'formative' dimension also. Both 'formative' and 'emotional' dimensions were strongly associated with intellectual virtues. We discussed below these differences more in detail.

As regards the association between VET institution leaders' positive virtues and leadership dimensions (RQ3), conceptually it was expected that

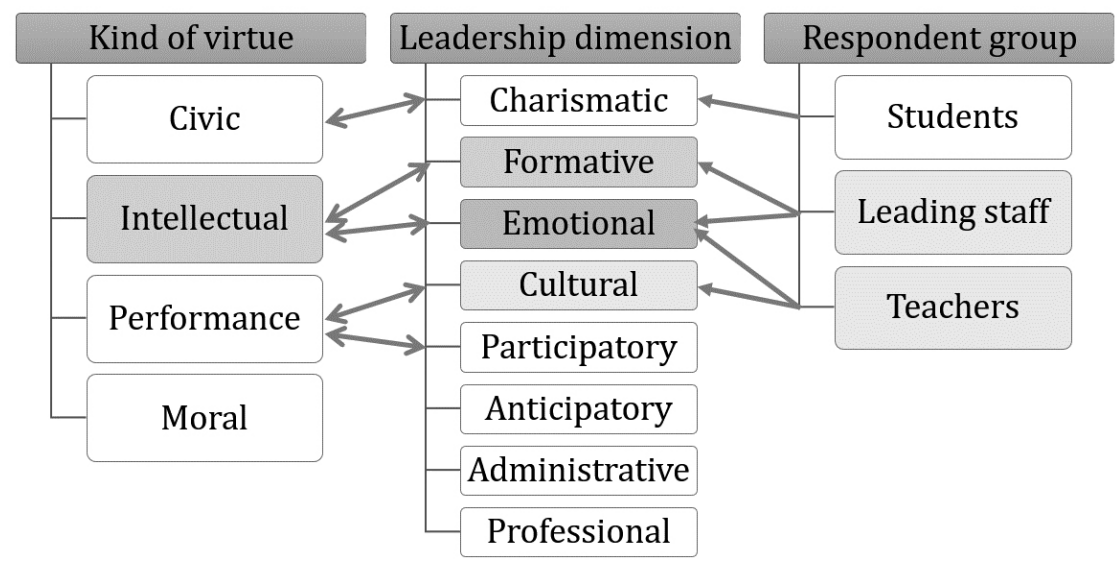

Figure 1. Leadership dimensions association with kind of virtues and respondent groups' activity 
civic virtues will be associated with 'participatory' and 'cultural' dimensions of leadership, which both demand the participative attitudes, civility and service included in the civic virtues. But instead, an unexpected strong association between leaders' civic virtues and the 'charismatic' dimension of leadership was found. This association may mean that, for participants, charismatic (attractive) leaders are the ones who are able to show in practice civic attitudes such as neighbourliness, community awareness and service. These results are coherent with the recent study regarding features of the character of VET institutions' pedagogical leaders (Fernández González, et al., in press), in which it was found that respondents showed higher concern and sensitivity about VET leaders' civic virtues (encouraging others, community awareness, teamwork ability).

It could be also expected that respondents will refer to leaders' intellectual virtues mostly when speaking about 'anticipatory' and 'formative' leadership dimensions, which demand far-sighting, critical thinking and judgement that intellectual virtues facilitate. The association with the 'formative' dimension was found in the data, but an unexpected strong association between intellectual virtues and the 'emotional' dimension of leadership was also revealed. This association may mean that, for participants, emotionally competent leaders (those who made people feel well, comfortable, secure and protected), are the ones who are perceived as having intellectual virtues (critical thinking, reflectivity, judgement and resourcefulness) that allows them to lead the institution smartly and efficiently.

These unexpected associations with 'charismatic' and 'emotional' dimensions were explored in-depth, looking at the results of the quantitative part of the study (see Table 1). 'Emotional' and 'charismatic' dimensions were highly-rated among the 8 leadership dimensions. After the 'professional' dimension, which was the highest rated both in importance and evidence, the 'emotional' dimension got the $2^{\text {nd }}$ rank in evidence and the $3^{\text {rd }}$ in importance; and the 'charismatic' dimension $-2^{\text {nd }}$ rank in importance and $4^{\text {th }}$ in evidence; both dimensions were rated higher than the average in importance and evidence. Conceptually, it could be expected that these two significant leadership dimensions would be associated with leaders' moral virtues (courage, justice, fairness, honesty and compassion), but instead, respondents linked them with civic virtues and intellectual virtues respectively. Respondents did not praise spontaneously their leaders' moral virtues when referring to 'charismatic' and 'emotional' dimensions, and they also rarely mentioned moral virtues in a positive mode, but they did it more often in desirable mode. This finding could be discussed in the light of recent literature stressing the relevance of the moral dimension of pedagogical leaders presented in the introduction (Day \& Gurr, 2011; Gurr, 2015; Butt, 
2017, etc.). This could mean that, in Latvian context, the perceived leaders' efficiency and civic behaviour are appreciated higher that their inner moral qualities, but more research is needed to confirm this hypothesis.

Conceptually, it could be expected that performance virtues will be associated with the 'professional' and 'administrative' dimension of leadership, in which performance virtues (such as resilience, determination and teamwork) would be most useful. Instead, unexpected strong associations of performance virtues with 'participatory' and 'cultural' dimensions were found (respectively, $67 \%$ and $56 \%$ of the associations within those dimensions). This means that, in general, respondents praised leaders' performance virtues when thinking about participation in school work and about the identity of their school. It is interesting to note that, in the quantitative analysis, the largest statistically significant differences between students and staff were found precisely in these two dimensions - 'participatory' and 'cultural' (see Table 2). It seems that institutional culture and participation are important aspects of leadership for school staff, but students rated their importance and evidence much lower.

When looking at the differences between respondent groups regarding the way they associate leaders' virtues with leadership dimensions (RQ4), it was assumed that each group of respondents was willing to highlight leaders' virtues when they were asked about those leadership dimensions that were more personally significant for them. Students praised VET institutional leaders' virtues mostly in relation with the 'charismatic' dimension of leadership, which is strongly related to civic virtues in our data. The personal significance of leaders' charisma for students was confirmed by the quantitative data (RQ2), which show that students rated higher than staff the importance and evidence of the 'charismatic' dimension (see Table 2). This seems to indicate that students appreciate particularly leaders' charismatic and attractive personality and his/her civic virtues, such as neighbourliness, community awareness and service, but more research is needed to confirm these findings at a larger scale.

Leading staff mentioned VET institution leaders' positive virtues in relation with the 'emotional' and 'formative' dimensions of leadership. According to the mentioned assumptions, this would mean that VET institution leaders were particularly concerned about students' and teachers' 'emotional' and 'formative' (professional development) needs. This association of the 'emotional' dimension with professional development, which is related to the intellectual virtues necessary for enhancing professional competence, is coherent with the association of intellectual virtues with the 'emotional' dimension of leadership discussed previously in this section of the paper. Teachers, like leading staff, were quite active when speaking about the 'emotional' dimension of leadership, which could indicate their concern 
about both their own and students' wellbeing. In their case, this emotional concern is not associated with the professional development ('formative' leadership dimension), but with the 'cultural' dimension of leadership (enhancing a sense of belonging). This is another remarkable difference with students, who rated the importance and evidence of the 'cultural' dimension much lower than staff in the quantitative study (see Table 2). More research would be necessary to explain these differences.

\section{Conclusion}

In this study, the most salient pedagogical leadership dimensions and their relationship with character features of the heads of three remarkable VET institutions in Latvia were explored, using quantitative analysis of questionnaire data and latent content analysis of interviews with students, teachers and staff.

The most salient leadership dimensions were the 'professional', 'charismatic' and 'emotional' ones. School staff rated the importance of 'professional', 'participatory' and 'cultural' dimensions statistically significantly higher than students. The following unexpected associations between VET leaders' virtues and leadership dimensions were found: between leaders' civic virtues and the 'charismatic' dimension of leadership (indicating that attractive leaders are the ones who are able to show civic attitudes); between intellectual virtues and the 'emotional' dimension of leadership (indicating that respondents feel emotionally satisfied when the institution is leaded smartly and efficiently); and between performance virtues and the 'participatory' and 'cultural' dimensions. Other group differences were that students praised VET leaders' virtues mostly while speaking about the 'charismatic' dimension of leadership, while leading staff and teachers did so while speaking about 'emotional' dimension. Leading staff also linked leaders' virtues with the 'formative' dimension of leadership, while teachers linked it more often with the 'cultural' dimension.

These results offer an original picture of the specific features of character of these exemplar institution leaders, who were able to combine personal charisma with civic attitudes and neighbourliness, and to create an emotionally rewarding institutional atmosphere, using their personal acumen and good sense for leading the institution successfully.

Compared with former research (Gento \& González, 2012) this study represents an innovative methodological contribution for investigating educational institution leaders' pedagogical leadership from the lens of virtue ethics. The use of a virtue framework for data analysis provided an ethically correct enriching perspective, and deep insights into VET leaders' personality. 
The limitations of the study are inherent to the qualitative methodology adopted. It may be useful to complete this approach with a quantitative study addressing the relation between leadership dimensions and leaders' virtues. It could be also interesting to compare the results of this study with similar ones in different geographical and cultural contexts.

\section{Acknowledgements}

Research financed by the European Regional Development Fund within the post-doctoral project (number 1.1.1.2/VIAA/1/16/071) and by the University of Latvia within the research project "Human, technologies and quality of education" (2016-2018) conducted at the Faculty of Education, Psychology and Art.

\section{References}

Attfield, R. (2015). Ethics of the Global Environment. Edinburgh: Edinburgh University Press.

Bluma, D., \& Daiktere, I. (2016). Latvia: School Principals and Leadership Research in Latvia. In: Ärlestig, H., Day, C., \& Johansson, O. (Eds.) A Decade of Research on School Principals: Cases from 24 Countries, vol. 21, 137-160. Springer, Cham. DOI: 10.1007/978-3-319-23027-6_8.

Butt, M. I. (2017). Principal, as a pedagogical leader: in the perspective of good governance in the public-sector colleges of Pakistan. Proceedings of $59^{\text {th }}$ ISERD International Conference, Sydney, Australia, $4^{\text {th }}-5^{\text {th }}$ January 2017, pp. 24-27.

CEDEFOP. (2015). Vocational education and training in Latvia: Short description. Luxembourg: Publications Office of the European Union. CEDEFOP information series.

Celma, D. (2004). Direktora loma pašpārvaldošas skolas veidošanā (Principal's role in developing a self-managed school). Latvijas Universitātes Raksti, 675, 48-55.

Çoğaltay, N., \& Karadağ, E. (2016). The effect of educational leadership on organizational variables: a meta-analysis study in the sample of Turkey. Educational Sciences: Theory \& Practice, 16(2), 603-646. DOI: 10.12738/estp.2016.2.2519.

Daiktere, I. (2012). School heads 'role in the process of developing school culture of comprehensive educational institutions in Latvia. Dissertation. Riga: University of Latvia.

Day, C., \& Gurr, D. (2011). Leading Schools Successfully: Stories from the Field. Routledge, London.

EQAVET (2016). Results EQAVET Secretariat Survey 2016. Retrieved from https://www. eqavet.eu/Eqavet2017/media/Documents/Report-implementation-of-EQAVET-ResultsEQAVET-Secretariat-Survey-2016.pdf [accessed 28 August 2018].

EQAVET [n. d.]. VET providers' self-monitoring by using the EQAVET toolbox of indicators (A Guide for National Reference Points). Retrieved from https://www.eqavet.eu/ Eqavet2017/media/Documents/GUIDE-VET-providers-self-monitoring-by-using-theEQAVET-toolbox-of-indicators.pdf [accessed 28 August 2018]. 
European Commission (2010). Communication from the commission to the European Parliament, the Council, the European Economic and Social Committee and the committee of the regions. A new impetus for European cooperation in Vocational Education and Training to support the Europe 2020 strategy. Brussels, 9.6.2010 COM(2010) 296 final. Retrieved from http://eur-lex.europa.eu/legal-content/EN/TXT/PDF/?uri=CELEX:5201 0DC0296\&from $=$ EN [accessed 28 August 2018] .

European Commission (2012). Commission staff working document: Vocational education and training for better skills, growth and jobs. Accompanying the document. Communication from the Commission. Rethinking Education: Investing in skills for better socio-economic outcomes. Strasbourg, 20.11.2012 SWD(2012) 375 final. Retrieved from http://eur-lex.europa.eu/legal-content/EN/TXT/PDF/?uri = CELEX:5201 2SC0375\&from $=$ EN [accessed 28 August 2018].

Fernández González, M. J. (2015). Possibilities of bilateral collaboration between Latvia and Switzerland in the field of vocational education and training. Recommendations about the priority fields and modalities of implementation of future collaboration. Report. Riga: University of Latvia.

Fernández González, M. J., \& Seņkāne, L. (2015). Educational leadership in higher education: professionalism versus emotional satisfaction. A case study from Lavia. In: I. Margeviča-Grinberga, G. Krağe, M. J. Fernández González, \& I. Odina (Eds.), Improving the Quality of Thinking and Action in Higher Education; The Roles of Cognition and Emotion. Proceedings of the $3^{\text {rd }}$ International RIAICES Congress (pp. 76-93). Riga: University of Latvia.

Fernández González, M. J., Pīgozne, T., Surikova, S., \& Vasečko, L.. (in press). Pedagogical leaders' personality relevance for vocational education quality. Quality Assurance in Education.

Gento, S. (2002). Instituciones Educativas para la Calidad Total. Madrid: La Muralla.

Gento, S., \& González, R. (2012). Leadership and Quality in Today's Educational Institutions of European Countries. Paper presented at the XIII Workshop of Qualitative Research n Psychology "Building bridges". March $11^{\text {th }}$ to $14^{\text {th }} 2012$, Achva Academi College of Education, Israel. Retrieved from http://www.leadquaed.com/docs/artic\%20ing/ Leadership\%20and\%20quality.pdf [accessed 28 August 2018].

Glenn, J. C., Gordon, T. J., \& Florescu, E. (2009). The Millennium Project. 2007 State of the Future. Washington: The Millennium Project.

Gurr, D. (2015). A model of successful school leadership from the International Successful School Principalship Project, Societies, 5, 136-150. DOI:10.3390/soc5010136.

Ho, R. (2006). Handbook of Univariate and Multivariate Data Analysis and Interpretation with SPSS. Boca Raton: Chapman \& Hall/CRC, Taylor \& Francis Group.

Huber, G. L., \& Gürtler, L. (2013). AQUAD 7 Manual: The Analysis of Qualitative Data. Tübingen, Germany: Softwarevertrieb Günter Huber.

Jäppinen, A.-K., \& Ciussi, M. (2016). Indicators of improved learning contexts: a collaborative perspective on educational leadership. International Journal of Leadership in Education, 19(4), 482-504. DOI: 10.1080/13603124.2015.1015616

JCCV, Jubilee Center for Character and Virtues. (2017). A framework for character education in schools. Retrieved from http://www.jubileecentre.ac.uk/userfiles/jubileecentre/pdf/character-education/Framework\%20for\%20Character\%20Education.pdf [accessed 28 August 2018].

Kalvans, R. (2012). The role of school principal quality assurance in education. $\mathrm{PhD}$ thesis. Riga: University of Latvia. 
Latvian Investment and Development Agency [n. d.]. State support program "Competence Centres". Retrieved from http://www.liaa.gov.lv/files/liaa/attachments/ informacija_par_projektiem_kas_tiek_istenoti.pdf [accessed 28 August 2018].

Latvijas Republikas Izglìtības un zinātnes ministrija (The Ministry of Education and Science) (2014). Par darba vidē balstitu mācību istenošanas iespējām Latvijas profesionālās izglitibas attistibas kontekstā. Informativais zinnojums. Retrieved from http://www.mk.gov. $\mathrm{lv} / \mathrm{lv} / \mathrm{mk} / \mathrm{tap} /$ pid $=40319533 \&$ mode $=\mathrm{mk} \&$ date $=2014-08-12 \quad$ [accessed 28 August 2018].

Latvijas Republikas Ministru kabinets (The Cabinet of Ministers) (2009). Noteikumi Nr. 629. Par koncepciju "Profesionālās izglïtibas pievilcỉbas paaugstināšana un sociālo partneru lìdzdalïba profesionālās izglītibas kvalitātes nodrošināšanā" (Conceptual position about "Attractiveness in Vocational Education and Social Partners within Vocational Education Quality Assurance). Last modified: 17.08.2012. Retrieved from http://likumi. lv/doc.php?id = 197894 [accessed 28 August 2018].

Latvijas Republikas Ministru kabinets (The Cabinet of Ministers) (2016). Ministru kabineta 20.12.2016. noteikumi Nr. 831 "Kārtïba, kādā akreditē izglïtibas iestādes, eksaminācijas centrus un citas Izglītibas likumā noteiktās institūcijas, vispārējās un profesionālās izglīīibas programmas un novērtēe valsts augstskolu vidējās izglīības iestāžu, valsts un pašvaldību izglïtibas iestāžu vadītāju profesionālo darbïbu". Retrieved from https://likumi.lv/ta/ id/287602-kartiba-kada-akredite-izglitibas-iestades-eksaminacijas-centrus-un-citasizglitibas-likuma-noteiktas-institucijas [accessed 28 August 2018].

Mårtensson, K., \& Roxå, T. (2016). Leadership at a local level - enhancing educational development. Educational Management Administration \& Leadership, 44(2), 247-262. DOI: $10.1177 / 1741143214549977$.

Mulford, B. (2003). School leaders: Changing roles and impact on teacher and school effectiveness. A paper commissioned by the Education and Training Policy Division, OECD, for the Activity "Attracting, Developing and Retaining Effective Teachers". Retrieved from http://www.oecd.org/education/school/2635399.pdf [accessed 28 August 2018].

Neuendorf, K. A. (2016). The Content Analysis Guidebook. London: Sage.

O’Byrne, D. (2017). Global Ethics and Civil Society. London: Routledge.

OECD (2016a). School Leadership for Learning: Insights from TALIS 2013. Paris: TALIS, OECD Publishing.

OECD (2016b). Reviews of National Policies for Education: Education in Latvia. Paris: OECD Publishing.

Ozola, Z. (2002). Development of the structure and the management of the private schools. Dissertation. Rīga: Latvijas Universitāte.

Robson, C., \& McCartan, K. (2016). Real World Research. London: John Wiley \& Sons.

Saeima (2014). Statement about approval of education development guidelines for 2014-2020. Retrieved from http://likumi.lv/doc.php?id=266406 [accessed 28 August 2018].

Schulz, W., Ainley, J., Fraillon, J., Losito, B., Agrusti, G., \& Friedman, T. (2016). Becoming citizens in a changing world. IEA International Civic and Citizenship Education Study 2016 International Report. SpringerOpen. Retrieved from: http://iccs.iea.nl/ fileadmin/user_upload/Editor_Group/Downloads/ICCS_2016_International_report.pdf [accessed 28 August 2018].

Shaw, W. H., \& Barry, V. (2015). Moral Issues in Business. Boston, MA: Cengage Learning. 
Smith, D., Kelly, D., \& Allard, C. (2017). Dialogic spaces: a critical policy development perspective of educational leadership qualifications. International Journal of Leadership in Education, 20(4), 393-415. DOI: 10.1080/13603124.2015.1116608.

Taipale, A. (2012). International survey on educational leadership. A survey on school leader's work and continuing education. Finnish National Board of Education. Retrieved from https://www.oph.fi/download/143319_International_survey_on_educational_leadership.PDF [accessed 28 August 2018].

The University of Nottingham (2015). International Successful School Principals Project (ISSPP): Multi-perspective research on school principals. Retrieved from https://www. uv.uio.no/ils/english/research/projects/isspp/isspp-brochure-27_jul_final_amended.pdf [accessed 28 August 2018].

Uljens, M., Sundqvist, R., \& Smeds-Nylund, A.-S. (2016). Educational leadership for sustained multi-level school development in Finland - A non-affirmative approach. Nordic Studies in Education, 36(2), 103-124.

Upenieks, A. (2008). The training and adaptation of new principals of education institutions for work in education institutions. Summary of the Promotion Paper. Latvijas Universitāte. 